\title{
VICTORIA UNIVERSITY OF WELLINGTON
}

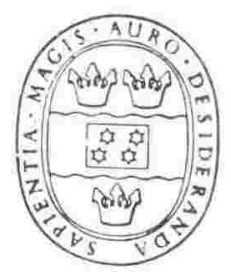

\section{AVAILABILITY OF THESIS}

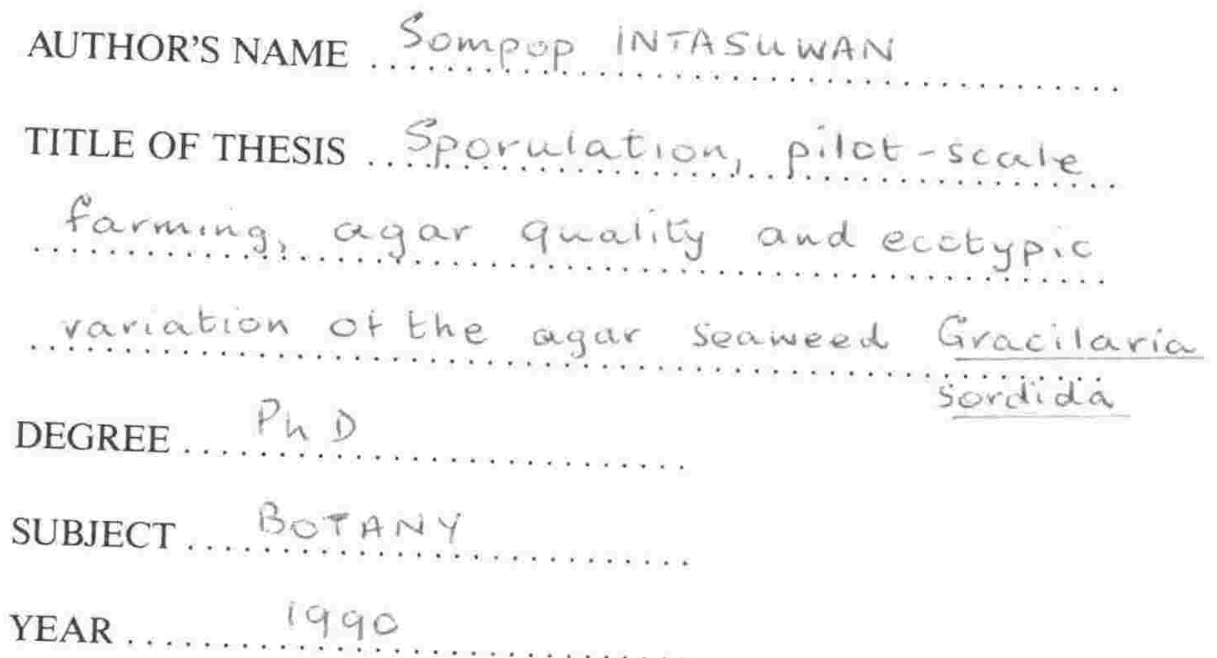

I hereby consent to the above thesis being consulted, borrowed, copied or reproduced in accordance with the provisions of the Library Regulations from time to time made by the Professorial Board.

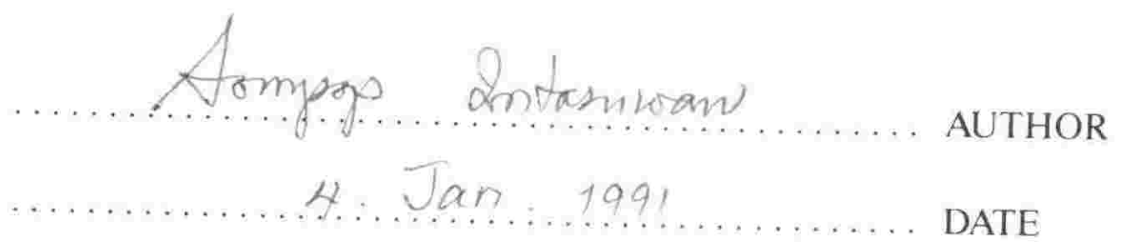


SPORULATION, PILOT-SCALE FARMING, AGAR QUALITY

AND ECOTYPIC VARIATION OF THE AGAR SEAWEED

GRACILARIA SORDIDA.

SOMPOP INTASUWAN

A thesis submitted in fulfilment of the requirements for the degree of Doctor of Philosophy in Botany,

Victoria University of Wellington, New Zealand. 1990.

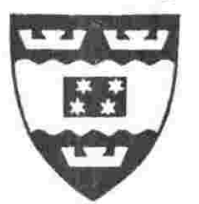




\section{ABSTRACT}

The purpose of this study was to investigate the sporulation behaviour, the feasibility of farming in an open-water system, the quality and quantity of agar from a range of populations, and the genetic variation of the important agarophyte Gracilaria sordida W.A. Nelson (Gracilariales, Rhodophyta), which is widely distributed around New Zealand.

The mean, total output of carpospores and tetraspores, and the periodicity of their release from $G$. sordida plants collected in the Wellington area, were measured under different levels of salinity, temperature, light intensity and daily exposure time to the air. The conditions that gave the greatest carpospore release were found to be approximately 15-35\%. $\mathrm{NaCl}, 15-20^{\circ} \mathrm{C}, 50-200 \mathrm{uE} \cdot \mathrm{m}^{-2} \mathrm{~s}^{-1}$ and 1-3 h daily exposure time. The conditions that gave the greatest tetraspore release were found to be approximately $15 \%$. NaCl, $15-20^{\circ}$ C, 150-200 uE.m $\mathrm{m}^{-2} \mathrm{~s}^{-1}$ and 2-4 h daily exposure time. The diurnal periodicity of carpospore and tetraspore discharge based on hourly recordings was also measured. The peak rate of spore output occurred in the moming (7:00-8:00 hours) and in the late afternoon (16:00-17:00 hours). The carpospores and tetraspores not only had the same size but also showed the same germination pattern.

A year-long pilot-scale farming project involving seeding the spores of sexually mature plants of $G$. sordida onto nets and ropes in Pauatahanui Inlet, Porirua Harbour, proved that this seaweed can be grown from spores on artificial substrates in field conditions. Of the artificial substrates tested, the best one for spore attachment was found to be polypropylene rope, and the relative growth rate on this substrate was maximal in spring $\left(3.4 \% . \mathrm{d}^{-1}\right)$. The estimated production rate was 18.2 tonnes of dry weight per hectare per year. Problems encountered during field culture included epiphytes, sedimentation, storm damage and theft of floats and ropes. 
Yield and gel strength of agar extracts were studied from G. sordida collected in summer from 23 sites around the country. Native agar yield ranged from $17 \%$ to $32 \%$ (dry weight). The yield of native agar from cultured samples of these populations ranged from $10 \%$ to $29 \%$. The yield of alkali-pretreated agar ranged from $9 \%$ to $24 \%$. The gel strength of native agar ranged from 30 to $307 \mathrm{~g} . \mathrm{cm}^{-2}$. Agar gel strength after alkali-pretreatment ranged from 230 to $625 \mathrm{~g} . \mathrm{cm}^{-2}$. Native agar gel strength from cultured samples ranged from 177 to $342 \mathrm{~g} . \mathrm{cm}^{-2}$. The gelling temperature of agar from wild populations ranged from 39 to $47^{\circ} \mathrm{C}$ for native agar and from 38 to $45^{\circ} \mathrm{C}$ for alkali-pretreated agar. The melting temperature of native agar ranged from 79 to $98^{\circ} \mathrm{C}$. The melting temperature of alkali-pretreated agar ranged from 85 to $98^{\circ} \mathrm{C}$. The maximum relative growth rate obtained from samples of $G$. sordida populations cultured in plastic bags was $6.2 \% . \mathrm{d}^{-1}$, which was obtained from the Aramoana population.

Starch gel electrophoresis of proteins was used to measure genetic variation in $G$. sordida. Protein extracts were prepared from 17 wild populations around New Zealand and from samples of these populations cultured in plastic bags. 20 isozyme loci were examined in G. sordida samples. Results indicated that G. sordida has low levels of genetic variation. Only two loci (Gd-1 and Pgm-1) of the 20 loci investigated were polymorphic (10\%). Estimated heterozygosity of $G$. sordida was 0.011 . There was no genetic variation between a native population and its cultured sample. The genetic distances between all populations were small. From the cluster analysis, all populations could be divided into two groups. Results indicated that populations were independent of each other, in which the effects of selection and genetic drift prevail. The buffer systems which gave the best protein resolution were Ridgeway (RW), Tris-EDTA-Borate (TEB) and Tris-Glycine (TG) and the enzyme which gave the best result in all buffer systems tested was Glucose-6-phosphate dehydrogenase (GD). 


\section{ABSTRACT (IN THAI).}

บหคัดย่อ

สาหร่ายสีแดง Gracilaria sordida (Gracilariales, Rhodophyta) เป็น ส่าหร่ายที่มีความสำคัญทางเศรษฐกิจของนิวซีแลนด์ โดยใช้สะกัดวุ้นและใช้เป็นอาหารเลี้ยงหอย เป๋าฮื้อ (abalone)

วัตถุประสงค์ของการวิจัยนี้เพื่อศึกษาปัจจัยที่มีผลต่อการปล่อยสปอร์, ความเป็นไปได้ สำหรับเพาะเลี้ยงในระบบเปิด, ปริมาณและคุณภาพชองวุ้น และความแปรผันทางพันธุกรรมของ สาหร่ายชนิดนี้

\section{ผลการวิจัยปรากฎดังนี้}

1. สภาพแวคล้อมที่กระตุ้นให้สาหร่ายปล่อยคาร์โปสปอร์ได้ดีทสุดคือ ช่วงความเด็ม ระหว่าง $15-35$ ส่วนในพัน, ช่วงอุณหภูมิระหว่าง $15-20$ องศาเซนเชียส, ความเข้มชองแสง ระหว่าง 50-200 ไมโครไอสไดน์/ตารางเมตร/วินาที และการผึ่งลมระหว่าง $1-3$ ชั่วโมง

สภาพแวดล้อมที่กระตุ้นให้สาหร่ายปล่อยเตตราสปอร์ไค้ดีที่สุดคือ ช่วงความเ ค็ม 15 ส่วนในพัน, อุณภูมิระหว่าง $15-20$ องศาเซนเขียส, ความเข้มของแสงระหว่าง $150-200$ ไมโครไอสไตน์/ตารางเมตร/วินาที่ และการผึ่งลมระหว่าง 2-4 ชั่วโมง

2. การทดลองทำฟาร์มเพาะเลี้ยงโดยเพาะสปอร์บนตาช่ายและเส้นเชือก แล้วนาไป ปลูกในอ่าวเป็นเวลา 1 ปิ พบว่าสาหร่ายชนิดนี้สามารถเจริญได้ดีบนวัสดุสังเคราะห์โดะเฉพาะ เชือกโพลีพรอไพลีน ( $\overline{R G R} 3.4 \%$ ต่อวัน) การเจริญสูงสุตปรากฎในฤดูใบไม้ผลิต ผลผลิตต่อป์ ประมาณ 18.2 ตัน (น.น.แห้ง) ปัญหาการเพาะเลี้ยงคือ Epiphytes ตะกอน คลื่นลมแรง และการลักขโมยทุ่น

3. ปริมาณวุ้นที่สะกัดได้จากสาหร่ายที่เก็บจากธรรมชาตมค่าระหว่าง $16-31 \%$ ความ แข็ง $30-370$ กรัม/ตารางเซ็ติเมตร ส่วนปริมาณวุ้นที่สะกัดจากสาหร่ายที่ได้จากการเพาะเลี้ยง ในถุงพลาสติกมีค่าระหว่าง $10-28 \%$ ค่าความแข็งระหว่าง $177-342$ กรัม/ตารางเซนติเมตร และปริมาณว้นที่สะกัดจากสาหร่ายแช่ด่างมีค่าระหว่าง $9-23 \%$ ค่าความแข็งระหว่าง $230-625$ กรัม/ตารางเขนติเมตร

4. การศึกษาความแปรผันทางพันธุกรรมโดยใช้เทคนิคอิเลกโตรฟอเรซิส พบว่า สาหร่ายขนิตนี้มีความแปรผ้นทางพันธุกรรมตำ จากจำนวน 20 ไอโชไชม์ โลไค มีเพื่ยง 2 โลไค $(\mathrm{Gd}-1$ และ Pgm -1$)$ ที่เป็นโพลีมอร์ฟิค $(10 \%)$ เฮทโรไข่โกซิตี มีค่า 0.011 . ไม่พบความ แปรผันทางพันธุกรรมระหว่างสาหร่ายที่เก็บจากธรรมชาติกับสาหร่ายที่ได้จากการเพาะเลี้ยง Genetic distance ในประชากรมึ่ค่าใกล้เคียงกัน แต่สาม่ารถแยกประชากรออกได้เป็น 2 กลุ่ม บัฟเฟอร์ที่ให้ผลดคือ $R$, TEB และ TG และโปรตีนที่ให้ผลชัดเจนที่สุดคือ GD. 
CONTENTS

Abstract ........................ I

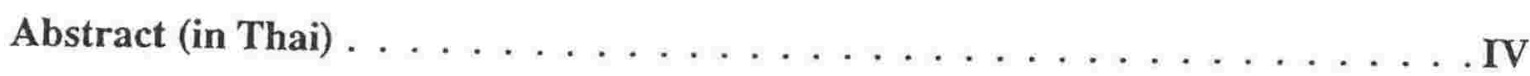

List of Figures . . . . . . . . . . . . . . . . VII

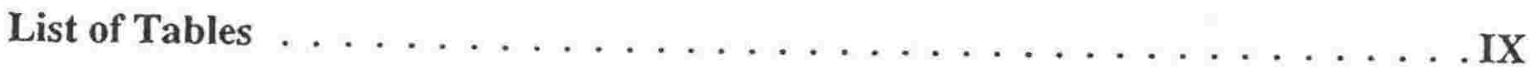

List of abbreviations and symbols . . . . . . . . . . . . . . X

Chapter 1 Introduction

1.1 Economic importance of Gracilaria . . . . . . . . . . . . . . .

1.2 Biology of Gracilaria . . . . . . . . . . . . . . . . . . . .

1.3 Mariculture of Gracilaria . . . . . . . . . . . . . 18

1.4 Objectives of the study . . . . . . . . . . . . . . . 35

Chapter 2 Sporulation of Gracilaria sordida

2.1 Introduction . . . . . . . . . . . . . . . . 37

2.2 Materials and methods . . . . . . . . . . . . . . . . 39

2.3 Results . . . . . . . . . . . . . . . . . . 45

2.4 Discussion . . . . . . . . . . . . . . . . . 68

2.5 Conclusion. . . . . . . . . . . . . . . 72

Chapter 3 Pilot-scale Farming of Gracilaria sordida

3.1 Introduction . . . . . . . . . . . . . . . . 73

3.2 Materials and methods . . . . . . . . . . . . . . . 75

3.3 Results . . . . . . . . . . . . . . . . . . . 90

3.4 Discussion . . . . . . . . . . . . . . . 110

3.5 Conclusion. . . . . . . . . . . . . . . . 114

Chapter 4 Comparison of agar yield and gel strength of

Gracilaria sordida populations

4.1 Introduction . . . . . . . . . . . . . . . 116

4.2 Materials and methods . . . . . . . . . . . . 118

4.3 Results . . . . . . . . . . . . . . . . . . . . . . 129 
4.4 Discussion . . . . . . . . . . . . . . . 141

4.5 Conclusion. . . . . . . . . . . . . . . . 145

Chapter 5 Ecotypic variations in Gracilaria sordida

5.1 Introduction. . . . . . . . . . . . . . . 146

5.2 Materials and methods . . . . . . . . . . . . . . 148

5.3 Results . . . . . . . . . . . . . . . . . 158

5.4 Discussion . . . . . . . . . . . . . . . . . . . 169

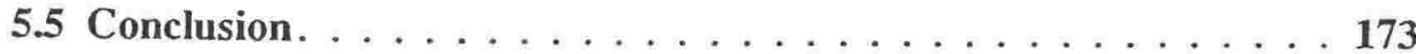

Acknowledgements . . . . . . . . . . . . . . . . . 174

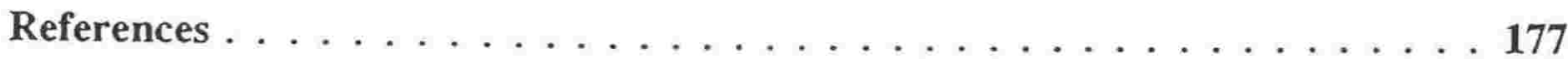

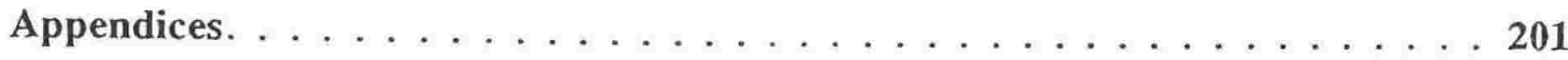

Appendix 1........................... 201

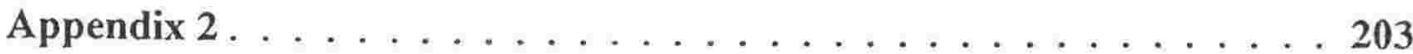

Appendix 3......................... 206

Appendix 4.......................... 210

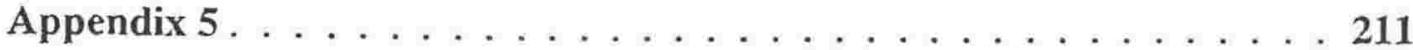

Appendix 6. . . . . . . . . . . . . . . . . . 212

Appendix 7 . . . . . . . . . . . . . . . . . 219

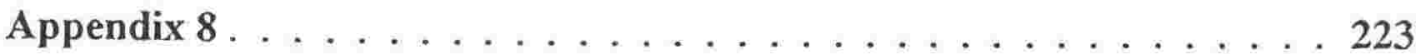

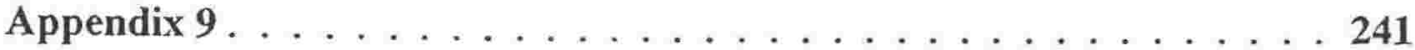

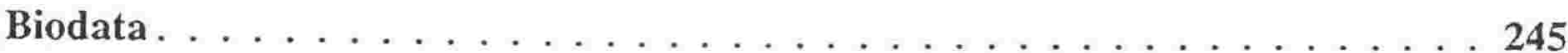




\section{LIST OF FIGURES AND PLATES}

Figure 1.1. Life history diagram of Gracilaria . . . . . . . . . . . . . . 10

Figure 1.2. Seaweed exports and agar imports of Thailand. . . . . . . . . . . . 27

Figure 1.3. Map of Thailand showing the test farm sites of the ATT project . . . . . . 29

Figure 2.1. Map of the North Island, New Zealand, showing the collection sites for the sporulation study . . . . . . . . . . . . . . . . . 41

Figure 2.2. The cumulative spore output as a function of salinity . . . . . . . . 46

Figure 2.3. The total spore output as a function of salinity . . . . . . . . . . . 48

Figure 2.4. The cumulative spore output as a function of temperature . . . . . . . . 50

Figure 2.5. The total spore output as a function of temperature . . . . . . . . . 52

Figure 2.6. The cumulative spore output as a function of light intensity . . . . . . . . . 54

Figure 2.7. The total spore output as a function of light intensity . . . . . . . . . 56

Figure 2.8. The cumulative spore output as a function of daily exposure time. . . . . . 58

Figure 2.9. The total spore output as a function of daily exposure time . . . . . . . . 60

Figure 2.10. The pattern of spore output over a 24 h period . . . . . . . . . . . . 662

Plate 2.1. Spore release in Gracilaria sordida . . . . . . . . . . . . . 65

Plate 2.2. Successive stages in tetraspore development in Gracilaria sordida . . . . . 66

Figure 3.1. Map of New Zealand, and of Pauatahanui Inlet and the farm site . . . . . . 77

Plate 3.1. Artificial substrates used in cultivation of Gracilaria sordida from spores. . . 80

Plate 3.2. Nursery tank and seeding frames at Victoria University Marine Laboratory, Island Bay, Wellington. . . . . . . . . . . . . . . . . . . . . . 84

Figure 3.2. Diagram showing the farm layout . . . . . . . . . . . 87

Plate 3.3. Farm installation at Duck Creek, Pauatahanui Inlet, Porirua Harbour, Wellington . . . . . . . . . . . . . . . . 88

Figure 3.3. Seasonal values of salinity, temperature, $\mathrm{pH}$, light intensity and nitrogen levels of the seawater at the farm site, Duck Creek . . . . . . . . . . . 91

Figure 3.4. The mean relative growth rate of Gracilaria sordida on different artificial 
substrates

Plate 3.4. Gracilaria sordida on nets seeded with spores, after 6 months of growth . . 98

Plate 3.5. Growth of Gracilaria sordida on polypropylene rope. . . . . . . . . . . . 101

Plate 3.6. Growth of Gracilaria sordida on Christmas-tree mussel rope . . . . . . . .103

Plate 3.7. Growth of Gracilaria sordida fronds in mesh bags and on insert line . . . . 104

Plate 3.8. Epiphytes of Gracilaria sordida . . . . . . . . . . . . . . . 108

Figure 4.1. Map of New Zealand showing the collection sites for agar analysis and protein extraction.

Plate 4.1. 301 plastic culture bag .

Figure 4.2. Flow diagram of the agar extraction process . . . . . . . . . . . 125

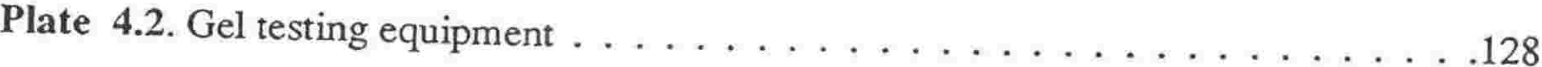

Figure 4.3. Comparison of mean agar yields (\% dry weight) of Gracilaria sordida and Gracilaria secundata from different sites . . . . . . . . . . . . . . . 132

Figure 4.4. Comparison of mean agar gel strengths $\left(\mathrm{g} . \mathrm{cm}^{-2}\right)$ of Gracilaria sordida and Gracilaria secundata from different sites . . . . . . . . . . . . . . . . 134

Figure 4.5. Mean gelling/melting temperatures $\left({ }^{\circ} \mathrm{C}\right)$ of the agar of Gracilaria sordida and Gracilaria secundata from different sites . . . . . . . . . . . . . 136

Figure 4.6. Mean gelling/melting temperatures $\left({ }^{\circ} \mathrm{C}\right)$ of the agar of Gracilaria sordida and Gracilaria secundata from different sites. . . . . . . . . . . . . . . 138

Figure 4.7. Mean relative growth rate $\left(\% \mathrm{~d}^{-1}\right)$ of tetrasporophyte plant of Gracilaria sordida in plastic bag culture

Figure 5.1. Diagram of electrophoretic apparatus . . . . . . . . . . . . 152

Figure 5.2. Phenogram showing the electrophoretic relationships of Gracilaria sordida populations

Plate 8.1 to 8.18. (Appendix 8) Details of the Gracilaria sordida collecting sites and habit details of typical plants. . . . . . . . . . . 223

Figure 9.1.(Appendix 9) Effect of washing time on agar yield and gel strength of Gracilaria sordida . . . . . . . . . . . . . . 243 


\section{LIST OF TABLES}

Table 1.1. The properties of the agar from three agarophyte species of Thailand . . . . 32

Table 2.1. Diameters of released carpospores and tetraspores of Gracilaria sordida . . . 63

Table 2.2. The experimental conditions which produced most spore release in Gracilaria sordida. . . . . . . . . . . . . . . . . . 69

Table 3.1. The mean relative growth rates $\left(\%, \mathrm{~d}^{-1}\right)$ of Gracilaria sordida on different substrates. . . . . . . . . . . . . . . . . . 95

Table 3.2. The relative growth rates $\left(\%, \mathrm{~d}^{-1}\right)$ of species of Gracilaria . . . . . . . . .112

Table 4.1. Properties of the agar extracts from tetrasporophytes of Gracilaria sordida and Gracilaria secundata from 23 sites in New Zealand . . . . . . . . . . . 130

Table 4.2. Agar yield (\% dry weight) and gel strength $\left(\mathrm{g} . \mathrm{cm}^{-2}\right)$ of Gracilaria sordida . .141

Table 5.1. Sampling locations for Gracilaria sordida used in isozyme analysis . . . . . 149

Table 5.2. Buffer systems used in starch-gel electrophoresis. . . . . . . . . . . . 155

Table 5.3. Enzymes and proteins assayed in all specimens. . . . . . . . . . . . . . . . . . . . . .

Table 5.4. Allozyme loci detected in screening tests

Table 5.5. Estimates of allele frequencies in Gracilaria sordida populations . . . . . . 161

Table 5.6. Genetic variability measurements for each population of Gracilaria sordida .164

Table 5.7. Matrix of genetic similarities and genetic distance coefficients between Gracilaria sordida populations . . . . . . . . . . . . . . . 166

Table 5.8. Comparison of the electrophoretically detectable enzymes of Gracilaria sordida and Gracilaria tikvahiae . . . . . . . . . . . . . . . . . . 170 


\section{LIST OF ABBREVIATIONS AND SYMBOLS}

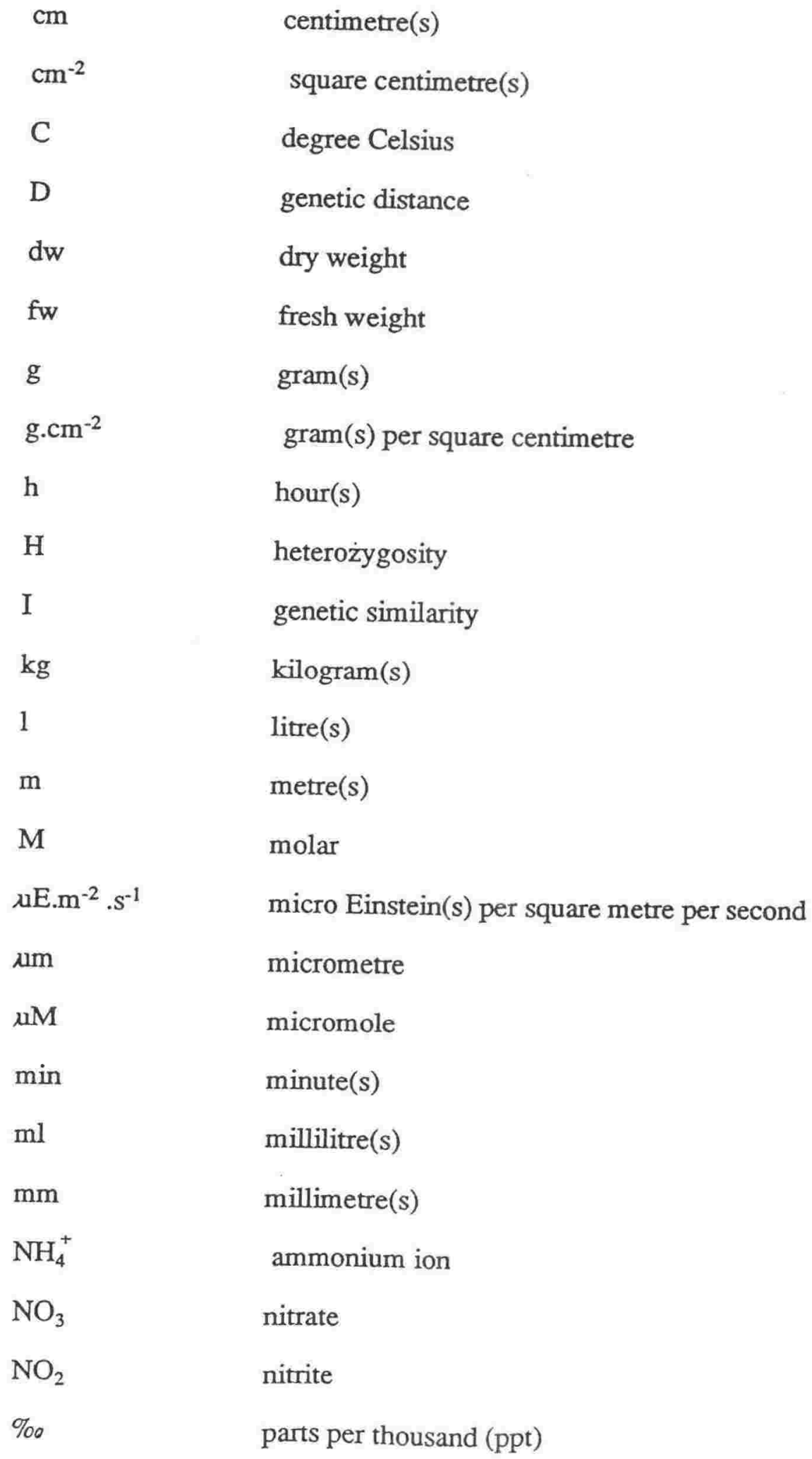


$\mathrm{p}$

$\mathrm{P}$

$\mathrm{PO}_{4}^{3-}$

$\%$

PES

Ipm

SD

t.ha- ${ }^{-1} \cdot y^{-1}$ probability

polymorphism

phosphate

percent

Provasoli's enriched seawater

revolutions per minute

standard deviation

tonne(s) per hectare per year 


\section{CHAPTER 1}

\section{INTRODUCTION}

\subsection{ECONOMIC IMPORTANCE OF GRACILARIA.}

Since the red seaweed genus Gracilaria was established by Greville in 1830 , more than 150 species have been recorded (Hoyle, 1975; Yamamoto, 1978). Gracilaria is the largest genus in the family Gracilariaceae, and probably more studies have been carried out on this genus than on any other in the red algae (Dawes, 1987). This interest is due not only to the rapid growth rate and broad distribution of Gracilaria in the subtidal and intertidal zones of temperate, tropical and antarctic regions but also to the economic importance of the genus (Dawes, 1987; Whyte and Englar, 1980). Gracilaria has been considered a prime candidate for phycoculture for various purposes including production of agar, bioconversion to methane, food for humans and animals, fertilizer and sewage treatment (Hanisak and Ryther, 1984).

\subsubsection{Gracilaria as a raw material for agar.}

Agar is a cell wall polysaccharide obtained from only certain red seaweeds known as agarophytes (Doty and Santos, 1983; Nelson, 1987). According to Chapman and Chapman (1980) there are 10 genera of red seaweeds utilized as sources of agar but the main agarophytes of commerce are species of Gracilaria, Gelidium, and Pterocladia. Agar has also been found in species of Acanthopeltis, Ahnfeltia, Campylaeophora, Gelidiella, Gelidiopsis, Phyllophora, and Suhria (Neish, 1979; Riddell, 1983; Rueness and Tananger, 1984). World annual harvest of red seaweeds for agar production is estimated to exceed 39,000 tonnes dry weight, consisting principally of Gracilaria species (60\%), Gelidium species (35\%) and Pterocladia species (5\%) (Whyte and Englar, 1980). 
The quality of agar from Gracilaria is lower than that from Gelidium and Pterocladia, but Gelidium and Pterocladia grow slowly, do not readily respond to aquaculture conditions and are not as easily harvested as Gracilaria. Moreover Gracilaria gel can be improved by alkaline processing. For these reasons Gracilaria species have been a more major source of agar than Gelidium and Pterocladia species (Hansen, 1984; Marsh, 1985; Gordon-Mills, 1986). Several surveys of the production and uses of agar have been published (Chapman and Chapman, 1980; Glicksman, 1987). The most important feature governing the demand for agar is the considerable strength of the gel, even at extremely low concentrations.

Chemically, agar consists of two components, agarose and agaropectin. The main component is agarose, a neutral polymer having repeating units of the disaccharide agarobiose (3-linked beta-D-galactopyranose units and 4-linked 3,6-anhydro-alpha-L-galactopyranose units). Agaropectin has essentially the same structure except that, to varying degrees, the units in the copolymer are replaced by sulphated, methylated or pyruvated sugar residues (McCandless, 1981; Glicksman, 1987; Lignell, 1988; Lahaye and Yaphe, 1988). Thus agaropectin carries a relatively high charge while agarose has a lower charge content. This ratio of agarose to agaropectin varies from species to species and the variation in this ratios, and in the degree of substitution with charged groups, results in differences in the quality of agar (Miller, 1979; Riddell, 1983; Marsh, 1985).

Agar is extracted by cooking the seaweed. Initially the dried plants are washed in cold water to remove excess salts and other contaminants. After soaking they are cooked or boiled. The water-soluble fraction is separated from insoluble matter by centrifugation, filtration, or both. The filtrate solution is allowed to gel at room temperature. The gel is either chopped, frozen, and thawed, or squeezed with a hydraulic press. The liquid released by either method is removed, carrying the impurities. The resulting gel flakes may be further washed and bleached. The purified gel is then dried and packaged as sheets, flakes, or powder (Okazaki, 1971; Lewis et al., 1988). 
Agar is used in various industries. The greatest use of agar is in the food industry and in pharmaceutical and medical applications. Agar is used for gelling and thickening purposes in bakery products, canned meats and fish, and confectionery. It is used in the manufacture of processed cheese, mayonnaise, puddings, creams and jellies. It is used as a clarifying agent in beers and wines.

In pharmacy and medicine, agar is important as an inert carrier for drug products where slow release is required, as a stabilizer for emulsions, and as a constituent of cosmetics, ointments and lotions. It is also used as an anticoagulant in wound dressing and as a laxative (brand name = Agarol). Another use is as the impression material for manufacturing plates for false teeth although alginate is now more commonly used.

The others industrial uses of agar are found in the textile industry where it is used as a sizing agent and in block printing. It is also used to give resilience to gelatin in photographic films (Levring, 1969; Dixon, 1973; McHugh and Lanier, 1983).

One of the most important uses of agar is as a culture medium for both microorganisms and higher organisms. Agar has a number of specific qualities which are well suited for an all-purpose culture medium (Marsh, 1985). These qualities are as follows:

- it can be kept as a low viscosity liquid at temperatures suitable for inoculation;

- it can be converted to a gel at temperatures which are non-injurious to most organisms;

- it can be kept at incubation temperatures without melting;

- it can be sterilised repeatedly without losing its other properties;

- it is transparent;

- it is non-toxic; and

- it is not degraded by most bacteria.

\subsubsection{Gracilaria as biomass for methane production.}


The use of seaweeds as a source of fuel (methane) is a new venture since the 1970s (Nelson, 1987). In the United States Gracilaria tikvahiae has been cultivated for this purpose (Hanisak, 1987). Ryther et al.(1979) grew Gracilaria in sewage-enriched tanks and obtained methane by fermentation of the biomass. He reported that a gas production range of 0.2 to $0.4{\mathrm{~L} . \mathrm{g}^{-1}}$ of Gracilaria, of which $60 \%$ was methane, could be obtained from the process (Dawes, 1981; Hansen et al., 1981). The giant kelp Macrocystis spp. has also been studied and cultivated in order to obtain energy (Benson and Bird, 1987).

\subsubsection{Gracilaria as a source of human food.}

Gracilaria species, like other red seaweeds, have long been used as food especially in Asian and Pacific countries (Trono, 1986). Although people around the world have developed their own seaweed cuisines, seaweeds are generally prepared in one of three ways (Hansen et al., 1981):

(1) washed and eaten raw,

(2) cooked or dried as a vegetable or flavouring,

(3) boiled and sweetened to make a jelly or custard.

In Japan, after Gracilaria species are washed free from salt water they are eaten, either raw or after boiling, as a salad or a garnish served with sliced raw fish, or they are cooked as a vegetable (Nisizawa et al., 1987; Ohmi, 1958). In Thailand, Gracilaria species are consumed fresh or blanched as salad vegetables or used in making soup (Lewmanomont, 1978). A number of books on seaweeds as foods, including recipes, are available. One of these is the Seavegetable Book by Madlener (1977) which gives worldwide seaweed recipes.

The importance of developing the potential of seaweeds as a food resource is further emphasized by the increasing population of the developing countries. Seaweeds are considered as potential inexpensive, effective dietary supplements for the malnourished (Michanek, 1981). Seaweeds in general are low in calories and protein, except for Porphyra, Gracilaria and Rhodymenia, which are quite rich in carbohydrate and protein. 
Most of the carbohydrates are not easily digested by humans because we lack the appropriate enzymes. In this sense they are comparable to roughage materials. However, they are good sources of various vitamins, minerals, and trace elements (Mathieson, 1975; Trono, 1986).

\subsubsection{Gracilaria as a source of animal food.}

In New Zealand and China, Gracilaria has been used as a food for abalone culture (Chiang, 1982; Pickering, 1986). In the Philippines Gracilaria is used as feed in fish ponds. (Hansen et al., 1981).

\subsubsection{Gracilaria in waste water treatment.}

Gracilaria species can be used as "nutrient scrubbers" for the removal of excess nutrients from aquatic systems such as agricultural land runoff, sewage, or animal mariculture effluents (Ryther et al., 1979; Hansen et al., 1981; Rueness and Tananger, 1984). In the United States, some red seaweeds such as Gracilaria and Hypnea have been used as nutrient scrubbers for secondarily-treated waste water and oyster effluent (Lapointe et al., 1976). The refinement and expansion of animal mariculture in enclosed systems is likely to encourage the large-scale integration of red seaweeds for purposes of nutrient scrubbing and ultimately for their phycocolloids. Cultivation of seaweeds for scrubbing purposes is less expensive than other waste water treatment methods and may be the only way to remove noxious elements from some kinds of wastewater (Hansen et al., 1981).

\subsubsection{Gracilaria as a source of fertilizer.}

Gracilaria has been used as supplementary manure in agricultural fertilizer in Taiwan (Liu et al., 1981). In southern Chile Gracilaria is also used as a manure, in the form of powder, liquid or whole decomposing plants, to cultivate potatoes (Kim, 1970). 


\subsection{BIOLOGY OF GRACILARIA.}

\subsubsection{Taxonomic status and general morphology.}

Division : Rhodophyta

Class : Rhodophyceae

Order : Gracilariales (formerly Gigartinales)

Family : Gracilariaceae

The genus Gracilaria is the largest genus in the family Gracilariaceae. It comprises about 150 described species distributed throughout the world (Dawson, 1966; McLachlan and Bird, 1986). The general characteristics of the genus are described in detail by Chapman (1979) as follows:

\footnotetext{
"Thallus usually with several erect branches emerging from a disc or prostate rhizome; erect branches dichotomously, trichotomously or irregular branched, bearing proliferous branchlets, often secund in arrangement, branches terete to compressed, fleshy to cartilaginous; structure of large, colourless, medullary cells and smaller cortical cells either sharply distinguished or grading gradually; spermatangia in superficial sori or in conceptacle-like depressions; carpogonial branches 2 celled; gonimoblast filaments growing from large, lobed fusion cell to surface of thallus; carposporangia formed from several cells at ends of gonimoblast; mature cystocarps external to thallus, sessile, hemispherical or beaked with thick pericarp and single ostiole; tetrasporangia cruciately divided, scattered in surface of thallus".
}

\subsubsection{Distribution and habitat.}

The genus Gracilaria is distributed in the subtidal and intertidal zones throughout the temperate, tropical, and antarctic regions of the world (Hoyle, 1975; Whyte and Englar, 1980). Some species are reported as widely distributed, whereas the distribution of others may be very limited (McLachlan and Bird, 1986). Different species are found in different 
habitats. However, species most commonly investigated for mariculture come from very similar habitats. These are found in shallow,moderately sheltered coastal water where the substrate is either mud or sand or a combination of both (Marsh, 1985).

In New Zealand at least three Gracilaria species are currently recognised after a recent taxonomic revision by Nelson (1987):

- Gracilaria secundata;

- Gracilaria sordida; and

- Gracilaria truncata.

G. secundata is found in the subtidal or intertidal zone on open coasts, growing in dense tufts on rocks. Plants have a purplish red to dark red-brown colour. The axes are round shaped in cross section with secund branching, and the male plants have horseshoe-shaped spermatangial conceptacles (Verrucosa type).

G. sordida is usually found all year round in harbours, estuaries or moderately exposed open coasts, attached to rocks, pebbles, shells or unattached but forming a mat on sand or mud flats. The thallus is brown to black colour with terete axes and spermatangial conceptacles are pit-shaped (Textorii type).

G. truncata is found in the subtidal zone, on rocks or shells of sandy locations. The plants have a pink to red colour. The axes are flattened with irregular branching. Spermatangial conceptacles are of the Verrucosa type (Nelson, 1987).

Of the three species, G. sordida is the one of interest for aquaculture for raw material to produce agar and as fodder for abalone (Terzaghi et al., 1987). Gracilaria sordida grows easily and quickly in protected waters around the country, particularly in harbours and estuaries. There are two different forms for Gracilaria sordida: (1) as plants unattached to hard substratum but generally partly buried in mud forming "mats" or "meadows" in shallow harbours; (2) as single plants each attached by a discoid holdfast to hard substrate such as rocks, pebbles and shells (Chapman, 1979; Nelson, 1988). 


\subsubsection{Reproduction and life cycle.}

The life cycle of several Gracilaria species has been studied (Ogata et al., 1972; Bird et al., 1977; McLachlan and Edelstein, 1977). The normal life cycle of Gracilaria shows an alternation of isomorphic, haploid gametophytes with a diploid carposporophyte and diploid tetrasporophyte (typical "Polysiphonia-type"). Lignell (1988) has studied the life cycle of G. sordida from Manukau Harbour, Auckland, and has found that this species also exhibits the "Polysiphonia-type" life cycle (Figure 1.1.)

Gracilaria species reproduce both sexually by the production of spores, and vegetatively by producing new plants from older parts (vegetative regeneration).

(1) Sexual reproduction

In typical Gracilaria species sexual reproduction involves four phases. These phases include two diploid spore-producing generations, the tetrasporophyte and carposporophyte, and two haploid gamete-producing generations, the male and female gametophytes. The gametophytic and tetrasporophytic stages are macroscopic forms but the carposporophytic stage is microscopic and it is parasitic on the female gametophyte (Trono, 1986). Equal numbers of male and female gametophytes are produced from tetraspores. The male plants produce spermatangia in antheridial pits under the surface of the thalli. The female plants form supporting cells from the outer layer of cells of the medulla, the supporting cells producing a two-celled carpogonial female branch and a number of laterals, a cell of which functions as the auxiliary cell. All of the cells of the procarp become multinucleate and develop into nutritive cells except for the carpogonial cell and the cell beneath it. After fertilization the carpogonium fuses with the nutritive cell that acts as an auxiliary cell. Subsequently this fusion cell fuses with the other multinucleate nutritive cells. At the same time the cortical cells above the procarp divide to produce the walls of this fruiting body or cystocarp, the inner cells of the wall constituting nutritive cells. Gonimoblast initials are cut off from the fusion cell and develop into an inner sterile area that supports and gives rise to the outer (distal) carposporangia. The carposporangia ripen successively from the outside in 
and are liberated from the ostiole of the cystocarp.

The carpospores germinate to produce a parenchymatous disc that forms the tetrasporophyte as an erect protuberance. The tetrasporophyte is morphologically similar to the gametophyte and about the same size as the female gametophyte. Cruciate tetrasporangia are formed terminally on laterals in the cortex and are embedded scattered over the thallus. The tetraspores each germinate to form a parenchymatous disc that produces the gametophyte as an erect protuberance (Ogata et al., 1972) (see Figure 1.1).

(2) Vegetative regeneration.

The holdfast and any portions of broken thalli are capable of growing to form a new plant if they are in a suitable habitat. 


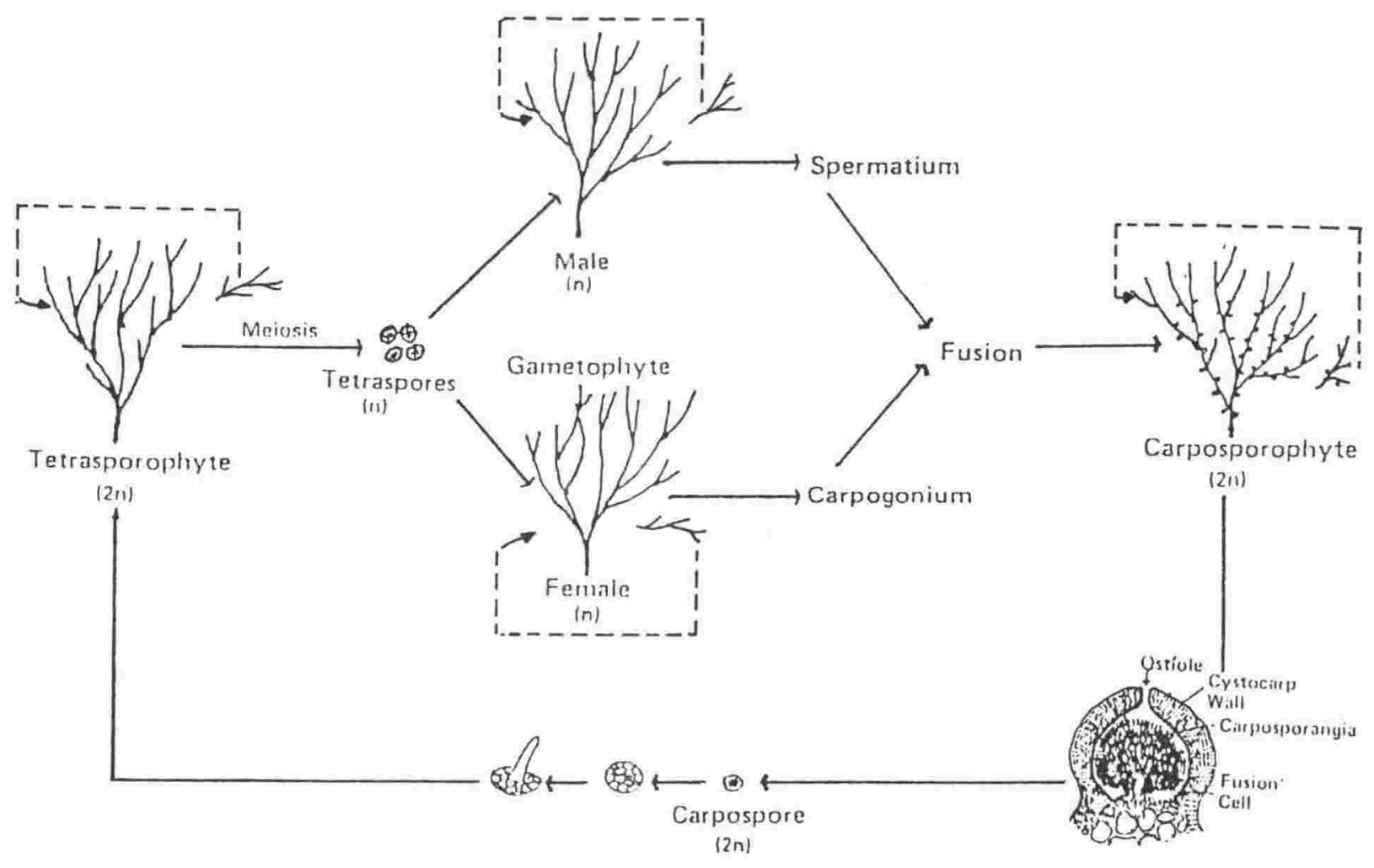

vegetative regeneration

Figure 1.1. Life history diagram of Gracilaria (Adapted from Santelices and Doty, 1989). 


\subsubsection{Factors affecting growth and distribution.}

Gracilaria is a perennial seaweed in cases where longevity has been determined. Its growth and distribution are affected by many factors. The factors affecting growth and distribution of Gracilaria can be placed in the following three basics categories:

(1) Physical factors:

- light, temperature, water motion, substratum, silt and desiccation.

(2) Chemical factors:

- salinity, $\mathrm{pH}$, nutrients.

(3) Biological factors:

- algal competition, grazers and environmental stress.

\subsubsection{Physical factors.}

(1) Light.

It is generally agreed that light is one of the two most important factors affecting seaweed growth. Light provides the energy source to run the plant. The response of seaweeds to the incident light varies according to the species, stage of development, available nutrients, water movement and temperature. The quality and quantity of light affect the growth, pigment concentrations and biochemical activity of Gracilaria. Levring (1957) and Ramus et al. (1976) have suggested that a combination of light quality and quantity are the causal factors of algal vertical distribution. The amount of light which finally reaches seaweeds varies with latitude, season, atmospheric conditions, and turbidity of water. In general, Gracilaria grows better with increasing light intensity (Kim, 1970; Lapointe and Ryther, 1979), and increasing shading usually leads to slow growth and abnormally small plants; however, the reported growth-saturating light levels for Gracilaria species vary a great deal from $50 \mu \mathrm{E} \cdot \mathrm{m}^{-2} \cdot \mathrm{s}^{-1}$. for G. tikvahiae (Bird et al., 1979) to $>1500$ uE.m. ${ }^{-2} \cdot \mathrm{s}^{-1}$. for G. sordida (Lignell and Pedersen, 1987). Lapointe and Duke (1984) reported that $G$. tikvahiae can maximise photosynthetic and growth rate through acclimation to very high $\left(860 \mu \mathrm{E} \cdot \mathrm{m}^{-2} \mathrm{~s}^{-1}\right)$ or very low levels $\left(60 \mu \mathrm{E} \cdot \mathrm{m}^{-2} \cdot \mathrm{s}^{-1}\right)$ of light. Glogau (1985) 
studied the effects of light quantity and quality on the growth of Gracilaria sordida from Manukau Harbour, Auckland, New Zealand. She reported that growth and photosynthetic rate of $G$. sordida increased linearly with increased light above $25 \mathrm{\mu E} \cdot \mathrm{m}^{-2} \cdot \mathrm{s}^{-1}$ and plants grown in blue, green and red light had higher growth rates than plants grown in white light.

\section{(2) Temperature.}

Temperature is one of the most important factors determining the general geographical distribution of certain seaweeds. It tends to interact closely with light, determining how that energy is used. Species of Gracilaria are found in a wide range of water temperatures. In general, increased temperature enhances growth until at a critical point further temperature increase decreases growth. Critical growth temperatures of different species of Gracilaria have been reported (Kim, 1970; Hoyle, 1975; Bird et al., 1979). The mechanisms of heat hardiness are not understood, but are thought to be associated with resistance to enzyme denaturation (Jackson, 1980). The peak growth periods of Gracilaria are usually found in summer and autumn (Hoyle, 1975), but high temperatures may influence morphology by inducing damage and hence decrease in thallus size (Norton et al., 1981). Seasonal adaptation in the temperature response of photosynthesis has been demonstrated in several red seaweeds. Some species of Gracilaria are quite hardy, becoming dormant during extremely low temperatures. Temperate species of Gracilaria are tolerant to a wide range in seasonal temperatures. The seasonal temperature fluctuation to which Gracilaria foliffera is exposed in the western north Atlantic ranges from $30^{\circ} \mathrm{C}$ in summer to $7^{\circ} \mathrm{C}$ in winter (Kim and Humm, 1965) and Gracilaria verrucosa in the Adriatic Sea can withstand a $5-28^{\circ} \mathrm{C}$ range (Simonetti et al., 1970).

(3) Water motion.

Water motion is an important physical factor influencing seaweed growth, distribution and abundance. The importance of water movement in controlling growth is to enhance diffusion around a thallus, thus making carbon dioxide and other nutrients more available to the alga, removing inimical extracellular products, and stimulating the respiration rate 
(Doty, 1971; Stewart, 1974). Water motion in natural systems is provided by currents and wave surge, and in culture by flowing water, bubble mixers, or paddles (Jackson, 1980). Experiments have confirmed the importance of water motion. Waaland (1976) found that seaweed growth depended on the extent to which the cultures were stirred. Matsumoto (1959) found that water currents were necessary for Porphyra growth. Hoyle (1978) reported that growth of Gracilaria parvispora in culture was greater in high water motion and high light intensity. A minimum water velocity is needed for optimum growth in Gracilaria (Edelstein et al., 1976; Saunders and Lindsay, 1979; Lapointe and Ryther, 1979).

(4) Substratum.

Most benthic seaweeds require a stable substratum. Particle size, colour, physical and chemical features of the substratum are properties which have considerable importance to seaweeds. For instance, a general relationship exists between the size of plants and particle size of the substratum, with only smaller plants growing on unstable substrate except in very quiet water (Hoyle, 1975; Norton et al., 1981). Gracilaria species may occur on almost any form of available substrate. The abundance of substrate material in lagoons or harbours is important for spores to settle and develop. While most Gracilaria species often grow on hard substrates (rocks, pebbles cockles, or shells) attached by a discoid holdfast, some Gracilaria species can survive unattached, free-floating or dense-lying on the bottom or partially embedded in mud on sheltered shores (Chapman, 1979; Umamaheswara Rao, 1972; Hoyle, 1975; Nelson, 1989).

(5) Silt.

Silt makes the water turbid and affects seaweeds adversely in three ways:

(a) by covering the substratum and limiting attachment of seaweeds;

(b) by reducing light penetration through the water column and through the layer of silt that might happen to settle on thalli, and

(c) by covering thalli and limiting diffusion between the cells and the medium (Hoyle, 1975). 
Silt is the main problem of pilot-scale Gracilaria farming in Thailand as silt covers spores on lines and reduces light penetration into adult thalli (Mumford, 1987).

(6) Desiccation.

During low tide exposure Gracilaria in the intertidal zone not only experiences salinity stress and sometimes temperature stress but also becomes dehydrated. Adaptation to desiccation varies with the vertical position in the littoral zone. The mechanisms of adaptation to drying conditions involve poorly understood, protoplasmic phenomena rather than any adaptation to retard the loss of water. Desiccation resistance seems to be determined primarily by the ratio of evaporating surface area to volume of the organs and not by mucilage content or wall thickness (Dromgoole, 1980). The exposure during low tide for most intertidal seaweeds is a stress condition to be endured until the tide covers them once again. The effect of desiccation varies with the length of time exposed, temperature, and other factors such as rainfall during the exposed period (DeWreede, 1980). Hodgson (1984) studied the desiccation tolerance of G. tikvahiae and found that desiccation greater than $60 \%$ led to a lower rate of photosynthesis and reduced the growth rate.

\subsubsection{Chemical factors.}

(1) Salinity.

A change in salinity affects the respiration rate by inducing osmotic stress and altering nutrient uptake rates of seaweeds (McLachlan and Bird, 1986; Rueter and Robinson, 1986). The salinity of seawater is expressed as \%o(parts per thousand) and the average salinity of seawater is about $34.85 \%$ (Kalle, 1972 cited in Hoyle, 1975). Salinity depends upon such factors as fresh water run-off, precipitation, evaporation and circulation. Gracilaria species are often found in brackish water, and show a wide range of tolerance to salinity. For example Gracilaria verrucosa in Madras, India, is found in salt marshes where salinities range from $2.5 \%-42 \%$ (Krishnamurthy, 1954 cited in Hoyle, 1975). Shang (1976) reported that the optimum salinity for Gracilaria confervoides in Taiwan is about $25 \%$. 
Overall, a salinity range of 15 to $20 \%$ has been found to be optimal for most species of Gracilaria (Trono, 1986). Pickering (1990) reported that the range of salinity for the fastest growth rate of G. sordida ranged from $23 \%$ to $33 \%$.

(2) $\mathrm{pH}$.

The $\mathrm{pH}$ of seawater ranges from 8 to 8.3 . Under normal conditions the $\mathrm{pH}$ range of seawater is not extensive enough to be important ecologically (Boney, 1966). Optimum pH for growth of Gracilaria in Taiwan is reported to be in the range of 6-9 (Shang, 1976). The growth rate of $G$. sordida was maximal at about pH 8 (Lignell and Pedersen, 1989). Results from tank cultivation of $G$. tikvahiae show the importance of maintaining the $\mathrm{pH}$ between 7 and 8 to achieve high production (DeBusk and Ryther, 1984).

(3) Nutrients.

Seaweeds are primarily photoautotrophic, using sunlight to produce organic matter from carbon dioxide, water and mineral ions. The availability of nutrients is one of the primary factors regulating the growth, reproduction and biochemistry of seaweeds. Nutrient enrichment studies have indicated that most of the economically important seaweeds are nutrient limited in their natural locations (Dawes, 1987). Various aspects of nutrient uptake and storage in Gracilaria have been studied by Lapointe (1981), Ryther et al. (1981), Bird et al. (1982) and Dawes et al. (1984). Nutrients enhance growth and photosynthesis in seaweeds. Changes in nutrient concentrations lead to changes in the rate of nutrient uptake, internal nutrient concentrations, and growth rates (Jackson, 1980). The most important limiting nutrients for seaweeds are nitrogen and phosphorus.

(a) Nitrogen.

Nitrogen is the element most often found to be limiting seaweed growth in the sea (Ryther, 1963). The most abundant form of nitrogen is dissolved $\mathrm{N}_{2}$, but it is inaccessible to seaweeds. Accessible nitrogen has been fixed into forms such as nitrate $\left(\mathrm{NO}_{3}^{-}\right)$, nitrite 
$\left(\mathrm{NO}_{2}^{-}\right)$, ammonia $\left(\mathrm{NH}_{3}\right)$, urea and amino acids. The most important sources for seaweeds are ammonia and nitrate. Seaweeds have been found to differ in their capabilities of utilizing various nitrogen sources. Gracilaria foliifera exhibited higher growth rates when supplied with ammonia $(50 \mathrm{\mu M})$ as compared with nitrate (DeBoer et al., 1978). In contrast, Pickering (1990) found that the growth rate of G. sordida at this nitrogen concentration is affected only by nitrogen quantity and not by nitrogen quality, although at higher concentrations (above $214 \mu \mathrm{M}$ ) growth rates were faster in the presence of nitrate because ammonia became supra-optimal. Several seaweeds, including Ulva lactuca (Chlorophyceae), Gracilaria foliifera (Rhodophyceae) and the kelps Alaria esculenta and Laminaria longicruis (Phaeophyceae), have been reported to store unused $\mathrm{NO}_{2}^{-}$in the vacuole (Chapman and Craigie, 1977; Rosenburg and Ramus, 1982). Ryther et al. (1981) suggested that phycoerythrin also acts as storage for surplus nitrogen in nutrient-sufficient plants. These reserves are believed to be utilized to sustain growth when external nitrogen levels are low (DeBoer, 1981). Nitrogen limitation results in lower growth rates, decreased content of nitrogen (both organic and inorganic), decreased chlorophyll content, decreased phycoerythrin content, lower light-saturated rates of photosynthesis and higher ammonia uptake rate (Darley, 1982). Soeder and Stengel (1974) found that blue light will enhance nitrate uptake and amino acid production in Gracilaria, suggesting that light quality in the subtidal regions may play a critical role in nitrogen metabolism.

(b) Phosphorus.

Phosphorus is another nutrient required for seaweed growth that is frequently depleted in seawater. The dominant chemical form in solution is orthophosphate ion. In average seawater at $\mathrm{pH} 8.0,20^{\circ} \mathrm{C}, 87 \%$ of the phosphate occurs as $\mathrm{HPO}_{4} \mathrm{~S}^{-2}, 12 \%$ as $\mathrm{PO}_{4} \mathrm{~S}^{-3}$, and $1 \%$ as $\mathrm{H}_{2} \mathrm{PO}_{4} \mathrm{~S}^{-}$(Riley and Chester, 1971). Some seaweeds have been reported to store excess phosphate in ionic form in the vacuole or in polyphosphate granules (Chapman and Craigie, 1977). 


\subsubsection{Biological factors.}

The growth rate is determined by the relative supply rates of nutrients, light and other factors. In culture conditions a reduction in growth rate can indicate self shading due to high densities, nutrient depletion, or changes in other processes needed to maintain optimal growth. There is ample evidence that Gracilaria species do follow an exponential growth pattern when cultured at low density (DeBoer and Ryther, 1977).

Seaweed growth in nature depends not only on the supply of nutrients and light, but also on effects of competition with other plants and on losses to animal grazers and pathogens.

(1) Algal competition.

Gracilaria growth can be decreased by other seaweeds or plants competing for attachment space, nutrients and light. Competition from algal weed species is an important problem in phycoculture when raising only the desired species. Techniques used to control weed species involve manually weeding undesirables or reseeding the wanted species or differentially increasing the growth rate of the wanted species by pulsing the nitrogen supply rather than supplying it continuously, as the weed species tend to be thin (filamentous or membranous) forms with little nutrient storing capacity (Jackson, 1980). Epiphytes, mainly Chaetomorpha, Ectocarpus, Enteromorpha, Ulva and Polysiphonia, are a serious problem in Gracilaria farming in China and Taiwan (Santelices and Doty, 1989).

(2) Grazers.

Animal grazing has been reported as a problem in some cultured seaweeds (Cheng, 1969). The major grazers are the molluscs (particularly the gastropods and chitons), crustaceans (particularly amphipods), and the sea urchins and fish (Jackson, 1980; South and Whittick, 1987). Grazing herbivorous snails on G. verrucosa have been reported in Florida (Hoyle, 1975). Predation by the herbivorous fish, Siganus species, on a Gracilaria pilot farm in Thailand has been reported by Mumford (1987).

(3) Environmental stress. 
There are several pathological conditions which are not organism induced: these are associated with nutrient deficiency, high temperature, low salinities, and high plant densities (Trono, 1986). A stress symptom called "ice-ice" appears under such conditions as low light, low water motion or low inorganic micronutrients. The thallus segments become discoloured, and then as the tissues die they become white, soft, and finally dissolve away (Santelices and Doty, 1989). The "ice-ice" symptom is found in Eucheuma and Gracilaria as well (Trono, 1986).

\subsection{MARICULTURE OF GRACILARIA.}

In recent years, the use of seaweeds as a source of phycocolloids has become a major worldwide industry. The extraction of agar, carrageenan, and alginic acid has depended largely upon the harvest of wild stocks of seaweeds in many part of the world, with the extraction process being undertaken by a few large companies. Increasing demand for seaweed as a raw material for phycocolloid products together with great fluctuations in yield from natural stands, has led to the research and development of a wide variety of seaweed cultivation techniques (Lignell, 1988).

Gellenbeck and Chapman (1983) suggested three major approaches by which cultivation techniques might be used to solve the supply problem. These are :

1) the discovery and development of new natural resources of phycocolloid-producing seaweeds,

2) improved management of existing seaweed stocks, and

3) the artificial culture (mariculture) of phycocolloid- producing seaweeds.

The first approach appears to have the least future because the new kinds of seaweeds must be abundant and grow in areas that are readily and commercially harvestable, and the possibilities are very few. Crop management has been applied to some brown seaweeds such as Macrocystis on the North American Pacific Coast and to Ascophyllum in Norway (Neish, 1979) but the most favoured approach is mariculture. 


\subsubsection{A definition of mariculture.}

The terms "mariculture" and "aquaculture" are not synonymous, but their meanings are similar. They both relate to the rearing of desired aquatic organisms under controlled conditions for economic or social benefit. The broader term "aquaculture" refers to the rearing of organisms in water whether fresh, brackish or marine. The main purposes of aquaculture are :

- to produce food;

- to improve natural stocks for commercial fishing;

- to produce ornamental species;

- to recycle organic wastes;

- to produce species for non-food products

"Mariculture" denotes that branch of aquaculture where organisms are grown in marine environments, including brackish waters (Marsh, 1985; Fernandez-Pato, 1989). Mariculture can be described as the managed cultivation and harvest of marine organisms (Hansen et at., 1981).

Mariculture has the advantage of providing employment, revenue, export production

and import substitution. Mariculture of seaweeds gives larger, more reliable, better quality crops, capable of genetic improvement and of easier harvesting compared with wild crops (Hollings, 1985).

\subsubsection{Types of seaweed mariculture.}

According to Gellenbeck and Chapman (1983) there are two basic types of mariculture,

1) Open system

2) Semi-closed system.

Seaweed cultivation in an open system is based on the concept that the ocean contains 5-10 times more potentially arable area than the land and that the land is almost fully exploited (Michanek, 1978). 
The open system uses structures placed in coastal waters to anchor the seaweeds. Seaweeds of only a few genera have been put under open system cultivation. The choice is generally dependent upon the market. The most successful open systems are those operating in Japan and China for the growth of seaweeds for human consumption. Species under cultivation include the Chlorophytes Enteromorpha, Monostroma, and Ulva, the Phaeophytes Laminaria and Undaria, and Rhodophytes of which Porphyra spp. are commercially the most important (Gellenbeck and Chapman, 1983; Tseng, 1981; Trono, 1986). These systems use large embayments of relatively calm water strung with various types of rope or netting for seaweed attachment. The ropes or nets are impregnated with spores or juveniles of the desired species before being deployed in the ocean. A similar type of culturing is conducted in the Philippines for the growth of Eucheuma. The culture of Eucheuma in the Philippines was pioneered by Dr Maxwell Doty of the University of Hawaii, using small pieces of plants tied to ropes and harvested after a sufficient growing period (Trono, 1986).

The semi-closed system uses shore-based artificial enclosures (tanks or ponds) as the culture vessels and supplies them with seawater pumped from, and returned to, the ocean. Semi-closed systems were first tried for Chondrus crispus in Nova Scotia, Canada, and in Florida, USA.

Species of many different genera of seaweed have been successfully grown and maintained in semi-closed systems, namely: Chondrus, Eucheuma, Gelidium, Gigartina, Gracilaria, Gracilariopsis, Hypnea, Iridaea, Neoagardhiella, Palmaria, Rhodoglossum and the brown seaweed, Sargassum (Gellenbeck and Chapman, 1983).

The advantage of semi-closed system culture is the possibility to optimise the supply of nutrients and. It is also easier to control epiphytes and to harvest than it is in open system culture but it costs more in term of construction, equipment and labour.

\subsubsection{Gracilaria cultivation in selected Asian nations.}


The total production of cultured seaweed in the Asia and Pacific region represents more than $90 \%$ of the total world production for seaweed and the biggest seaweed producing countries are in Asia (Trono, 1986). Therefore, the trends in seaweed cultivation of some nations in this region will be reviewed.

With the exception of Porphyra cultivation in Japan which commenced in the 1650 s, the culture of seaweeds is fairly recent. For instance, the culture of Laminaria was developed in China around 1927 (Tseng, 1986); in Taiwan, pond cultivation of Gracilaria was started in 1962; the commercial cultivation of Eucheuma in the Philippines was introduced in the early 1970s; the culture of Undaria was developed in Japan and Korea around 1964 (Trono, 1986; Tseng and Fei, 1987).

Although reports of seaweed culture are available from many Asian countries, such as India, Indonesia, Sri Lanka, Burma, Malaysia, Vietnam and Thailand, cultivation of seaweeds in these countries is still in its initial stage. Although some countries are known to produce small amounts of dried seaweed which somehow reach the international markets, their production has been derived mainly from the harvesting of natural crops. At present commercial production of seaweeds through culture is limited to some countries in the Asian-Pacific region, namely Japan, China, Korea, Taiwan, the Philippines, Fiji and Tonga (Tseng, 1981; Trono 1986). Other countries have recently started research and development work on their seaweed resources, especially on Gracilaria species. Gracilaria has become the main focus of study because of its economical importance (major source of agar), rapid growth rate and broad distribution (Dawes, 1987).

\subsubsection{Gracilaria cultivation in Taiwan.}

Gracilaria cultivation started in 1962 in southwestern Taiwan. In the first period between 1962 and 1970, the cultivation was on a very small scale, but by 1971 it had become a widespread means of livehood for farmers. This change was due to the decline of harvestable wild populations, to a significant price increase for the dried seaweed, and to 
improvements in culturing techniques. The production of Gracilaria through pond culture has achieved a high degree of success. An average of 12,000 tonnes of dried Gracilaria per year has been produced during the past few years (Chiang, 1981).

The reasons for success are :

1) agarophytes command a much higher market price than carrageenophytes,

2) labour costs are relatively low where Gracilaria is presently cultivated, and

3) Gracilaria can be polycultured with shrimp and/or crab so costs are kept low as the culture facility already exists (Hansen et al., 1981).

Several species of the genus are presently used, such as Gracilaria chorda, G. edulis, G. verrucosa, G. lichenoides, G. compressa and G. gigas, but G.verrucosa is the most popular species because of its ability to adapt to a wide range of ecological conditions, its higher production rates and better gel quality.

Shang (1976) has described the tidal ponds as generally one hectare in area. The water is kept at 20-30 cm deep from March to June and raised to $60-80 \mathrm{~cm}$ deep after June throughout the rest of the summer to compensate for seasonally high temperature. The plants thrive at temperatures between 20 and $25^{\circ} \mathrm{C}$.

For the best Gracilaria growth, the following criteria are considered in the selection of sites for pond culture:

1. The site should be located near seawater and fresh water resources in order to adjust the proper range of salinity.

2. The area should be protected from strong winds because there is a tendency for Gracilaria to accumulate on one side of the pond by wind.

3. The pond bottom should be at or near the low tide level because the tidal movement is necessary to facilitate exchange of pond water.

4. The pond bottom should be sandy loam because Gracilaria easily gets buried in ponds with a clay bottom due to the effect of wind.

5. The $\mathrm{pH}$ of the water should be between 6 and 9 (optimum $=8.2-8.7$ ) (Shang, 
1976).

The culture of Gracilaria, as described by Shang (1976) generally begins in April. The ponds are dried for several days to kill off potential weed and epiphyte species, and seawater is then introduced. Healthy stocks of Gracilaria are selected as planting material. The planting material is transported from its source to the pond site early in the morning to prevent its exposure to the sun. Upon arrival the planting material is immediately cut into pieces and broadcast uniformly on the bottom of the pond. The plants are held in place by a fish net cover or by bamboo poles. The stocking density is usually 5,000 to $6,000 \mathrm{~kg}$ plant material per hectare.

Pond water is exchanged every two or three days to maintain proper salinity and temperature, and to replenish nutrients. At each exchange about 50 to $75 \%$ of the pond water is drained and replaced with fresh seawater. The crop is weeded at least three times a year. Milkfish and Tilapia are stocked in the same pond at the rate of $300-400$ fish per hectare to graze on the epiphytes.

Either organic or inorganic fertilizer can be used to enhance the growth of the Gracilaria. Weekly application of three $\mathrm{kg}$ of urea per hectare is sufficient. Alternatively, fermented pig manure may be applied at a dosage of 130 to $180 \mathrm{~kg}$ per hectare two or three days after the water exchange.

The harvesting season starts in June and extends to November. The crop may be harvested every 10 to 40 days either manually or by using scoop nets. The crop is thoroughly washed and sun-dried. Dried Gracilaria is then packed into sacks of $100 \mathrm{~kg}$ weight for export or sold to local processing plants. The annual harvest from a hectare of pond is ten to twelve metric tonnes of dried Gracilaria.

Gracilaria is also reared in polyculture with grass shrimp (Panaeus monodon) and crabs (Scylla serrata) to produce additional profits. 


\subsubsection{Indonesia.}

In Indonesia, commercial seaweed mariculture is presently concentrated on the extension of the monoline method of culturing Eucheuma (Soegiarto, 1978; Trono, 1986). Coast Biologicals Ltd. from New Zealand has established a factory and Eucheuma farm near Jakarta (Hopkinson, 1989). However a Japanese company has recently established Gracilaria pond culture in Sumbawa.

\subsubsection{Malaysia.}

In Malaysia, surveys of the feasibility of seaweed farming have been carried out. Two species of Gracilaria which grow naturally off the coast of Penang have been selected for trial. Preliminary work on the field culture of Gracilaria using hatchery-produced sporelings was successful. The Penang seaweed project was sponsored by the United Nations Development Programme (UNDP) and used the facilities of Glugor Fisheries Research Institute, Penang, Malaysia (Bay of Bengal Program, FAO/SIDA. 1987).

\subsubsection{Burma (Myanmar).}

In Burma, Gracilaria edulis is presently cultured using the fixed-pole net and long-line float system (Trono, 1986). The system uses Gracilaria cuttings attached to culture nets which are supported by long lines with floats. Plants attain harvestable size after 2 to 3 months. Harvesting is done by pruning.

\subsubsection{Vietnam.}

Eleven species of Gracilaria have been reported in Vietnam. Culture of this genus is presently practiced in brackish water ponds and in lagoons. The culture method is similar to the technique used in Taiwan (Truong et al., 1988). 


\subsubsection{Sri Lanka.}

A systematic survey of agar-producing seaweeds has been done in Sri Lanka. Two species of Gracilaria, namely $G$. confervoides and $G$. lichenoides were found to be potentially suitable for culture. Only preliminary studies on their culture were made using coir nets (Amandakoon, 1981 cited in Trono, 1986). In 1975, Sri Lanka ran a successful pilot trial using Gracilaria lichenoides (Mchugh and Lanier, 1983).

\subsubsection{India.}

In India, Gracilaria corticata, G. edulis and Gelidiella acerosa were found to be the main agarophytes. The mariculture of $G$. edulis, using vegetative pieces attached to ropes or nets, has been developed with assistance from the Land-to-Land Programme of the Indian Council of Agricultural Research (Raju and Thomas, 1971).

\subsubsection{The Philippines.}

In The Philippines, Gracilaria culture has been tried at Bacoor Bay in the south of Manila Bay, by the Bureau of Fisheries and Aquatic Resources (BFAR). Initial results have shown that production of wild stock can be doubled by placing a solid substratum (such as cement blocks, adobe blocks or shells) on the sea floor. Although this method has shown good potential, it has not yet been taken up by local fishermen. At present trials with pond culture of Gracilaria are being implemented at Bacoor Bay too (McHugh and Lanier, 1983; Trono, 1986).

\subsubsection{Singapore and Brunei.}

Singapore and Brunei have just initiated research and development work on seaweed culture. 


\subsubsection{Thailand.}

Thailand has over $2,600 \mathrm{~km}$ of coastline which supports a rich and diverse flora of tropical marine seaweeds. Lewmanomont (1978) surveyed the seaweeds along the coast of the Gulf of Thailand and the Indian Ocean to assess their economic importance and found that five genera of red seaweeds, two genera of green algae and four genera of brown seaweed were being used for food. In addition, three of these genera of red seaweeds were also being used as a source of agar, namely Gracilaria, Hypnea and Gelidium. Edwards et al. (1982) made a survey of the potentially commercially important seaweeds along the - coastline of 22 provinces and found six such genera including Gracilaria in all these provinces.

Algal cultivation is a young technology in Thailand, started about 20 years ago with fresh water algae. In 1970 The Thai-German Algal Research Project was initiated at the Institute of Food Research and Product Development, Kasetsart University, Bangkok. The major objectives have been the outdoor mass production of the green alga Scenedesmus acutus as a source of "single-cell protein" and utilization of the product as a food stuff for humans (Sinchumpasak, 1980). A private company (Siam Algae Ltd), culturing the blue-green alga Spirulina in concrete ponds and exporting it to Japan to make a protein supplement food, was started in 1979. At present (1990), commercial cultivation of seaweed not only has been established in the South of Thailand but also an agar extraction factory (Pure Agar Ltd) has been built at Rajburi Province (150 km south of Bangkok).

Thailand exports seaweed raw material to developed countries and subsequently imports the processed products, the phycocolloids (Figure 1.2). The highest export quantity was found in 1980 (203.3 metric tonnes) and the lowest quantity was in 1983 (60.1 metric tonnes). Most of dried seaweed exports to Japan. It is important to note that the Thailand exports figures are also included the figures of blue green algae (Spirulina). 

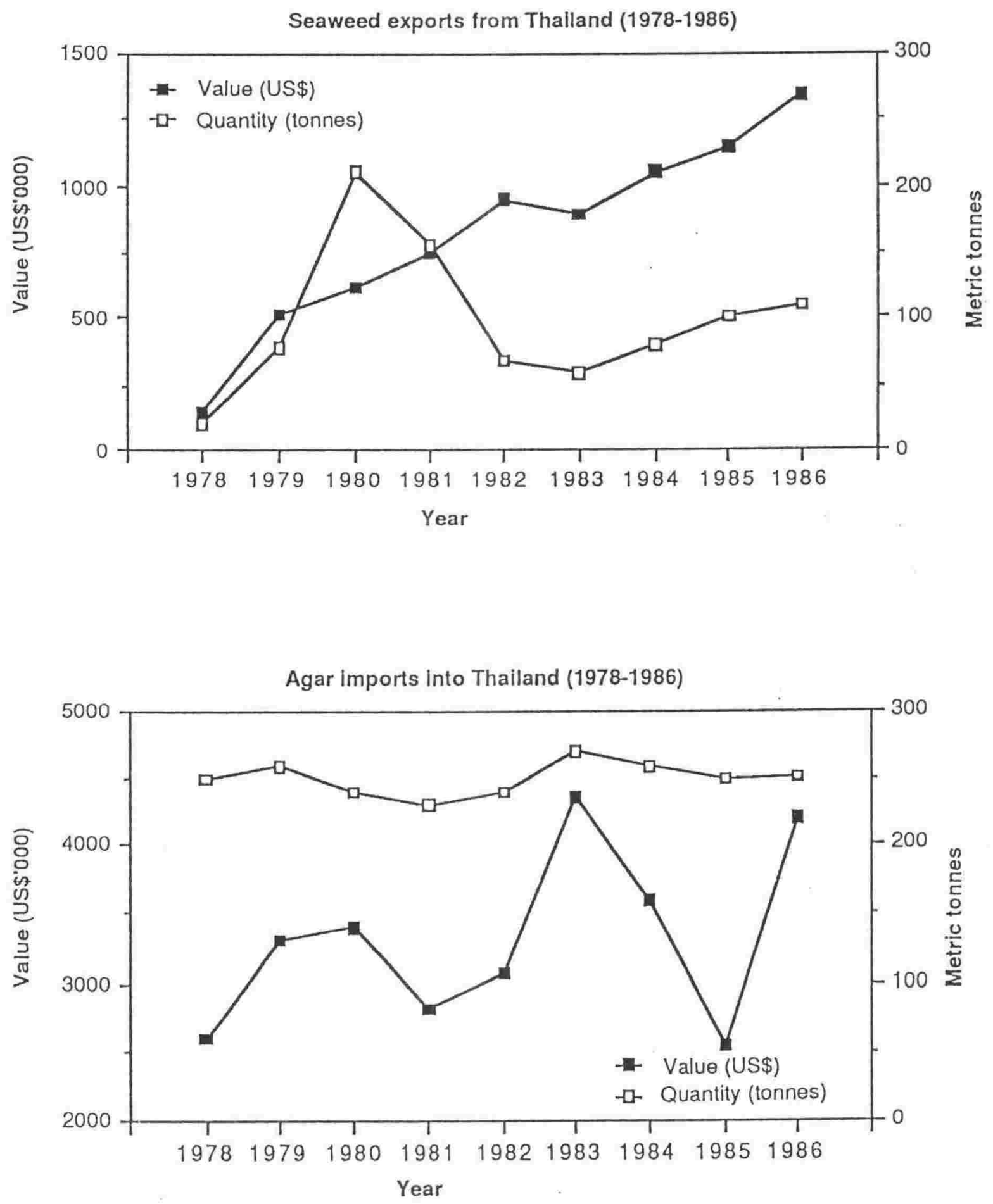

Figure 1.2. Seaweed exports and agar imports of Thailand. 
Edwards et al., (1982) reported that the most important seaweed colloid imported into the country is agar and most of this is food grade agar. Analysis of the Thai Government agar import statistics shows that there was an increasing trend in the quantities of agar imported into the country from 1978 to 1986 . The value of imported agar from 1978 to 1986 was about US\$3.3 million per annum, and this increased rapidly from 1975 to 1979 because of rising costs and an increase in demand (Santos, 1987). In 1986 Thailand imported 251.9 metric tonnes of agar, an increase of $7.6 \%$ over the previous year. Its value at nearly US\$ 4.1 million was approximately $8.5 \%$ greater than the year before. It is anticipated that Thailand's agar imports will continue to increase at an average annual rate of 8-10\% due to increased demand for agar used in food, tissue culture and various laboratory applications. At present, Thailand faces an annual trade deficit in agar of about US\$4 million.

In an effort to reduce this trade deficit, and as a means of creating employment for many coastal people, the Thai Government initiated the Agricultural Technology Transfer Project (ATT), entitled "Seaweed Production and Processing". The project was initiated in February 1986 for an 18 month period. It has been a joint project between the Department of Fisheries (DOF) of the Ministry of Agriculture and Cooperatives, Kasetsart University (KU), and Srinakharinwirot University (SWU). Hawaiian Agronomics (International) Inc. was contracted to provide consulting services to impart fundamental knowledge to relevant DOF and university staff through in-country and overseas training. (At present (1990) the ATT project has been continued as a joint research project between DOF, KU and SWU). The project was divided into three research areas: farming, processing and economics.

Test farms have been set up at 19 locations in 8 provinces using a variety of methods (see Figure 1.3). 


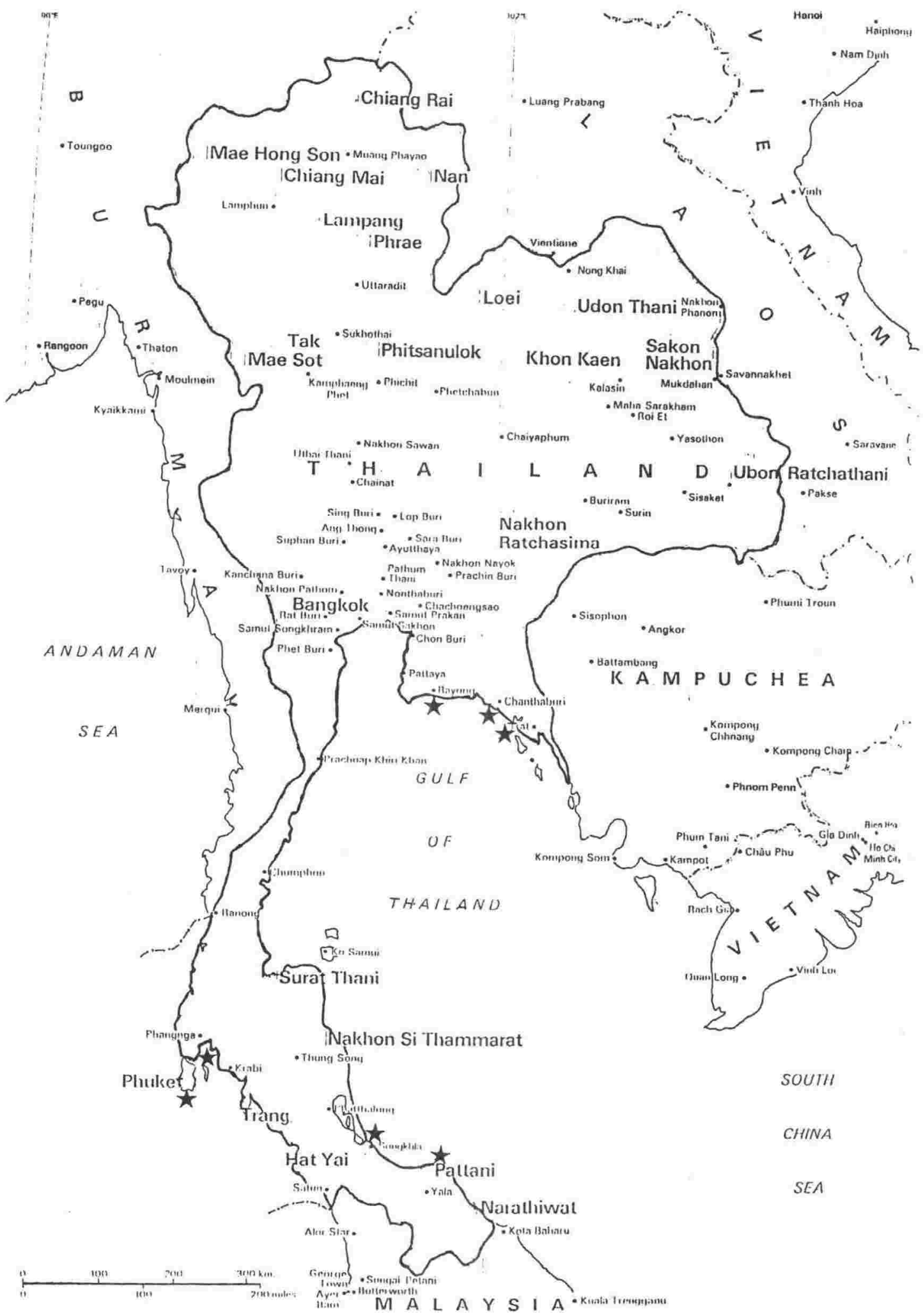

Fig. 1.3. Map of Thailand showing the test farm sites of the ATT project ( $\star$ ). 
The test farms were designed to answer the following questions:

1) what species should be grown (what)?

2) in what locations (where)?

3) and what methods should be used (how)?

1) Identification of suitable species and analysis of agar qualities.

In 1975, Velasquez and Lewmanomont reported that there were three species and one form of uncertain affinity of Gracilaria in Thailand. During 1986-1987, team members of the ATT project collected more than 12 species of native agarophytes around the coast of Thailand. All of the agarophyte samples were submitted to Dr I. A. Abbott, Botany Department, University of Hawaii, and Prof. Khanjanapaj Lewmanomont of Kasetsart University for identification or new description. Four were identified as belonging to the genus Polycavernosa and the other four as belonging to Gracilaria.

The names of the species of Gracilaria and Polycavernosa identified by the ATT team are as follows (Abbott, 1988):

Gracilaria species:

- Gracilaria firma.

- Gracilaria irregularis sp.nov.

- Gracilaria salicornia

- Gracilaria tenuistipitata var.liui.

Polycavernosa species:

- Polycavernosa changii.

- Polycavernosa fastigiata.

- Polycavernosa fisheri.

- Polycavernosa percurrens. sp.nov. 
Of the eight species only three, Polycavernosa changii, $P$. fastigiata and $P$. fisheri were found to produce good quality agar and recognized as possessing desirable gel qualities (Mumford, 1987) (see Table 1.1). The agar was extracted from native (untreated) and alkali-treated seaweeds. The freeze-thawing method was used to obtain the solid agar. The gel strength (1.5\% conc) was determined by the Japanese "Nikkansui Shiki" type of gel tester manufactured by Kiya Seisakusho Ltd. 
Table.1.1 The properties of the agar from three agarophyte species of Thailand (After Santos, 1987).

\begin{tabular}{|c|c|c|c|c|c|}
\hline Species & Treatment & Yield(\% dw) & Gel Str (g.cm-2) & Gel Temp $\left({ }^{\circ} \mathrm{C}\right)$ & Melt Temp $\left({ }^{\circ} \mathrm{C}\right)$ \\
\hline \multirow[t]{2}{*}{ P. changii } & Native & 37.5 & 265 & 30.5 & 86 \\
\hline & Alkali & 44.2 & 480 & 35.4 & 87 \\
\hline \multirow{2}{*}{ P. fastigiata } & Native & 28.5 & 40.3 & 32 & 89 \\
\hline & Alkali & 39.7 & 831 & 35.2 & 91 \\
\hline \multirow[t]{2}{*}{ P. fisheri } & Native & 23.7 & 160 & 28.5 & 85 \\
\hline & Alkali & 26.7 & 947 & 37.5 & 96 \\
\hline
\end{tabular}


2) and 3) Locations and culture methods.

Four potential seaweed culture methods (long lines, insert lines, cage culture and pond culture) have been investigated and it has been found that substratum preferences and best growth rate are dictated by the requirements of the species themselves. Thus three different farming techniques have been found to be appropriate for five of the Gracilaria /Polycavernosa species studied as follows:

$P$. changii: bottom orientated braided rafia long lines or monofilament netting.

$P$. fastigiata: as for $P$. changii.

$P$. fisheri: surface orientated polypropylene net curtains or long lines. Also pond culture.

G. tenuistipitata: pond culture, bottom orientated monofilament long lines or nets.

G. firma: bottom orientated polyethylene long lines or netting.

Although establishment of an agar processing industry was suggested more than fifty years ago (Boonak, 1935), there is only one commercial or industrial-scale agar manufacturing facilities in Thailand. One of the major constraints in developing such facilities in Thailand is the availability of a consistent, reliable and high quality source of raw material (Hollenbeck, 1987).

\subsubsection{Gracilaria cultivation in New Zealand.}

New Zealand has a relatively long coastline and about 700 species of seaweeds grow here, some of which are unique to this part of the world. The important red seaweed resources of New Zealand are Pterocladia, Porphyra and Gracilaria (Nelson, 1987).

Pterocladia spp. (Gelidiales, Rhodophyceae) are harvested commercially for producing high grade agar.

Porphyra spp. (Bangiales, Rhodophyceae) constitute the red seaweed traditionally 
harvested as food by Maori people.

There are about 150 species of Gracilaria known world-wide, of which New Zealand has at least three. Of these, only one, Gracilaria sordida, is known to grow easily and quickly, and to have commercial value. The commercial value of Gracilaria sordida is as fodder for marine animals (abalone), and for processing to produce agar (Terzaghi et al., 1987).

In 1983, a research group comprising scientists from Fisheries Management Division of MAF, Victoria University and DSIR's Plant Physiology and Chemistry Divisions produced a technical report on "The Potential for Mariculture of Seaweeds in New Zealand" (Christeller et al., 1983). In this report the research team argued that mariculture of Gracilaria for production of agar is the most promising area for New Zealand seaweed aquaculture development. At present, there is considerable interest among private individuals and companies around the country in farming Gracilaria sordida for abalone food and for agar.

A number of studies have already been carried out on Gracilaria culture in New Zealand. Dr Karl Johnson (1981) of the Auckland Regional Authority cultured Gracilaria in concrete seawater storage tanks at the Manukau Sewage Purification Works, Auckland from 1978 to 1981 . The culture medium was enriched by secondarily-treated sewage effluent. This study indicated that high growth rates were possible if the medium was aerated but this system was not cost effective (Johnson, 1981). Drs Ian Miller and Richard Fumeaux of DSIR Chemistry Division (1987) have been investigating the possibility of improving the quality of agar from Gracilaria by desulphation techniques. Drs John Christeller and William Laing (1989) have carried out experiments on growth rates, agar yield and gel strength of Gracilaria under different light, nutrient and temperature regimes. Mr. Graeme Olsen and Mr. Timothy Pickering (1986) have investigated the feasibility of spray culture of Gracilaria at Mahanga Bay Shellfish Hatchery, Wellington. A seaweed research group at Otago University is studying various aspects of New Zealand economic seaweeds, including Gracilaria sordida and Porphyra columbina (University of Otago Marine Science Bulletin, 1990). 
A number of valuable research projects by university graduates and staff on several aspects of Gracilaria such as farming methods, growth rate, agar quality and quantity in relation to season, is being conducted around the country and the findings could have direct relevance to mariculture. Ms. Michele Glogau Stevens, Ph.D. student under Dr Frank Dromgoole, University of Auckland, is working on photosynthesis, particularly acclimatization to varying light levels; Mr. Timothy Pickering, Ph.D. student with $\mathrm{Dr}$ Margaret Gordon, Victoria University of Wellington, has been studying the growth, phenology, agar quality and food quality for abalone of G. sordida (Pickering, 1990); Ms. Payao Intasuwan, graduate student with Dr Margaret Gordon, has studied the seasonal variation in agar yield and gel strength of G. sordida from three different sites; Ms. Anita Pillai, Ph.D. student with Dr Murray Brown, University of Otago, has been studying the ecophysiology of $G$. sordida at two field sites, including growth rates, regeneration, chemical composition of the agar, nutrient uptake, photosynthesis and effect of desiccation.

\subsection{AIMS OF THE STUDY.}

In New Zealand, interest in farming Gracilaria both for agar and as a feed for cultivated abalone, has increased considerably during the last few years. Small-scale aquaculture experiments are in progress, the properties of the agar of some Gracilaria sordida populations have been examined and processing techniques involving alkaline extraction have been developed to improve the agar. Several business firms are now ready to conduct field trials. At the time the present study was initiated, however, we still lacked basic knowledge concerning:

- the biology of sporulation, spore development and the environmental factors that accelerate spore discharge, knowledge which would provide information concerning the feasibility of low-cost farming by seeding a farmable type of substrate in the open water;

- the range of variation in agar quality of $G$. sordida and the relative contributions of genetic and environmental factors to this variation. 
The main purposes of this study are :

1. to examine the effects of environmental factors on the spore-producing activity of Gracilaria sordida which has implications for mariculture practice, for example in devising methods for seeding nets or ropes with spores.

2. to investigate the potential for open-system culture of Gracilaria sordida in New Zealand using sporulation techniques to seed the nets or ropes.

3. to investigate the agar qualities of Gracilaria sordida populations from different sites around the country. The comparison of agar quality and quantity, from "native" and alkaline treated weeds, both freshly collected and after culture in common conditions, is essential to determine the extent to which the agar properties are genetically or environmentally controlled.

4. to investigate the extent of genetic variation as revealed by isozyme differences, among New Zealand populations of Gracilaria sordida with a view to locating the best strains.

This thesis begins with an overview of present general knowledge of Gracilaria mariculture, and current research on $G$. sordida to provide a conceptual framework for the following chapters. Current knowledge of Gracilaria spore biology, the results of experiments on effect of environmental factors on spore release and the application of this knowledge to farming by seeding of spores onto substrates is provided in Chapter 2. The farming of Gracilaria sordida on a pilot-scale, by seeding nets and lines with spores, the records of growth rate and environmental conditions and the problems encountered are described in Chapter 3. Chapter 4 provides the results of an analysis of agar quality and quantity of $G$. sordida from different areas around New Zealand. This is followed by an analysis of the genetic variation of $G$. sordida populations from different sites around the country using starch-gel electrophoretic techniques (Chapter 5). 


\section{CHAPTER 2}

\section{SPORULATION OF}

GRACILARIA SORDIDA.

\subsection{INTRODUCTION.}

Cultivation trials for Gracilaria have been carried out worldwide by many researchers (Raju and Thomas, 1971; Shang, 1976; Lindsay and Saunders, 1977; Chiang, 1981; Edelstein et al., 1981; Goldstein, 1981; Ren et al., 1984; Santelices and Ugarte, 1987; Rotmann, 1987; Camara Neto, 1987; Friedlander et al., 1987; Hanisak, 1987; Pickering, 1990).

There are two approaches to initiating the cultivation of Gracilaria, namely by means of spores and by means of vegetative fragments (Raju and Thomas, 1971). Most of the work on Gracilaria culture cited above used vegetative fragments as planting material. There is little information concerning culturing Gracilaria from spores. Vegetative propagation has been attempted in preference to cultivation by means of spores because vegetative propagation is easier and yields quicker results (Raju and Thomas, 1971).

Although the spore seeding method has the disadvantage that there is a lag period of growth it has two advantages. Firstly the thalli can tolerate wave action because they are securely attached to the substrate by holdfasts, and secondly, the method can enhance Gracilaria natural stocks at a favourable site. Wood (1946) and Saunders and Lindsay (1979) suggested that the culturing of Gracilaria through the outplanting of seeded substrate represents an alternative method of enhancing the wild stock in the natural beds. Enhancing or expanding the natural stocks by providing a solid substratum, such as cement blocks, adobe blocks, shells and gravel, on the sea floor, has shown good results in the Philippines (Trono, 1986). Cultivation of Gracilaria by setting the spores on lines or nets and outplanting these in sheltered harbours has shown good potential in pilot-scale farming in Malaysia and Thailand (Doty and Fisher, 1987; Mumford, 1987). 
Cultivation of Gracilaria by means of spores depends on a fundamental knowledge about spore production, spore release, spore viability, spore germination and sporeling growth. The number of spores produced by a selected portion of Gracilaria depends on a number of variables, e.g. (1) age of the plant, (2) the part of the plant, (3) the physiological state of the plant, (4) the degree of maturation of the developing spore-bearing tissue, (5) the modifying effects of environmental factors triggering the process (Dromgoole, pers comm.). It has been reported that the release and growth of spores from seaweeds are affected by many environmental factors such as light, temperature, $\mathrm{pH}$, salinity, daily desiccation time, tidal rhythms and lunar rhythms (Kim, 1970; Ngan and Price, 1983; Friedlander and Dawes, 1984). Studies on spore release and germination of Gracilaria have been reported by several workers (Jones, 1956; Oza, 1975; Oza and Krishnamurthy, 1967; Bird et al., 1977; Ngan and Price, 1983; Friedlander and Dawes, 1984; Chen and Ren, 1987; Edding et al., 1987; Lewmanomont, 1987; Levine, 1988).

There are two types of spore development in red seaweeds: discoidal development (Dumontia type) and filamentous development (Naccaria type). In discoidal development, a spore divides and forms a discoid, radially symmetrical germinal disc. In the filamentous type, a spore divides and produces a filamentous mat with a rhizoidal base. The filamentous type of development has been considered less typical because it is observed infrequently (Sylvester and Waaland, 1984). Spore germination in Gracilaria species is of the discoidal type: a spore divides forming a multicellular disc which serves as an attachment organ (holdfast) for development of the erect fronds from its central region (Bird et al., 1977).

The aim of this pilot study was to examine the effects of salinity, temperature, light intensity and daily desiccation time on the spore release of Gracilaria sordida, with the intention of supplying information relevant to mariculture practice. This information may make it possible to obtain a large quantity of spores for seeding directly onto substrate by using environmental conditions to induce sporulation (environmental shock-inducing technique). 


\subsection{MATERIALS AND METHODS}

The study was carried out at Victoria University of Wellington, New Zealand, between April 1987 and May 1988, using fresh material of Gracilaria sordida collected periodically in the Wellington area. Cystocarpic and tetrasporic plants of Gracilaria sordida were collected on subtidal rocks at Scorching Bay in Wellington Harbour and on a sandy mudflat at Pauatahanui Inlet (Duck Creek) in Porirua Harbour (Figure 2.1). The collecting sites differ not only in the nature of the substrate but also in the density of the Gracilaria populations, the population at Pauatahanui Inlet being denser than at the Scorching Bay site.

\subsubsection{Description of collecting sites.}

Scorching Bay (41 $\left.11^{\circ} \mathrm{S}, 174^{\circ} 51^{\prime} \mathrm{E}\right)$ is a semi-exposed sandy beach with rocky headlands near the entrance to Wellington Harbour (Port Nicholson). The Gracilaria population is located intertidally and in the upper subtidal zone on large cobbles and rocks that are embedded in sand.

Pauatahanui Inlet ( $41^{\circ} 06^{\prime} \mathrm{S}, 174^{\circ} 54^{\prime} \mathrm{E}$ ) is the eastern arm of Porirua Harbour, which is situated on the west coast of the North Island, $20 \mathrm{~km}$ north of Wellington City. It is a tidal estuary with surrounding tidal mudflats (Irwin, 1976). At the collecting site (Duck Creek), the intertidal zone consists of fine sand/mud sediments. It is adjacent to urban land and receives run-off and fresh water from Duck Creek. Gracilaria plants are found on a rocky outcrop and on cockles and small pebbles on the mud flat.

During the period of the experiment, the environmental conditions at the collection sites (average values) were as follows: 


\begin{tabular}{lcc} 
Factors & Scorching Bay & Pauatahanui Inlet \\
\hline $\mathrm{pH}$ & 8.1 & 8.0 \\
Salinity $(\%)$ & 30 & 30 \\
Temperature $\left({ }^{\circ} \mathrm{C}\right)$ & 13 & 14 \\
* Subsurface & 450 & 300 \\
light intensity (uE.m $\left.{ }^{2} . \mathrm{S}^{1}\right)$ & & \\
\hline
\end{tabular}

* $1 \mathrm{ft}$ below the surface 


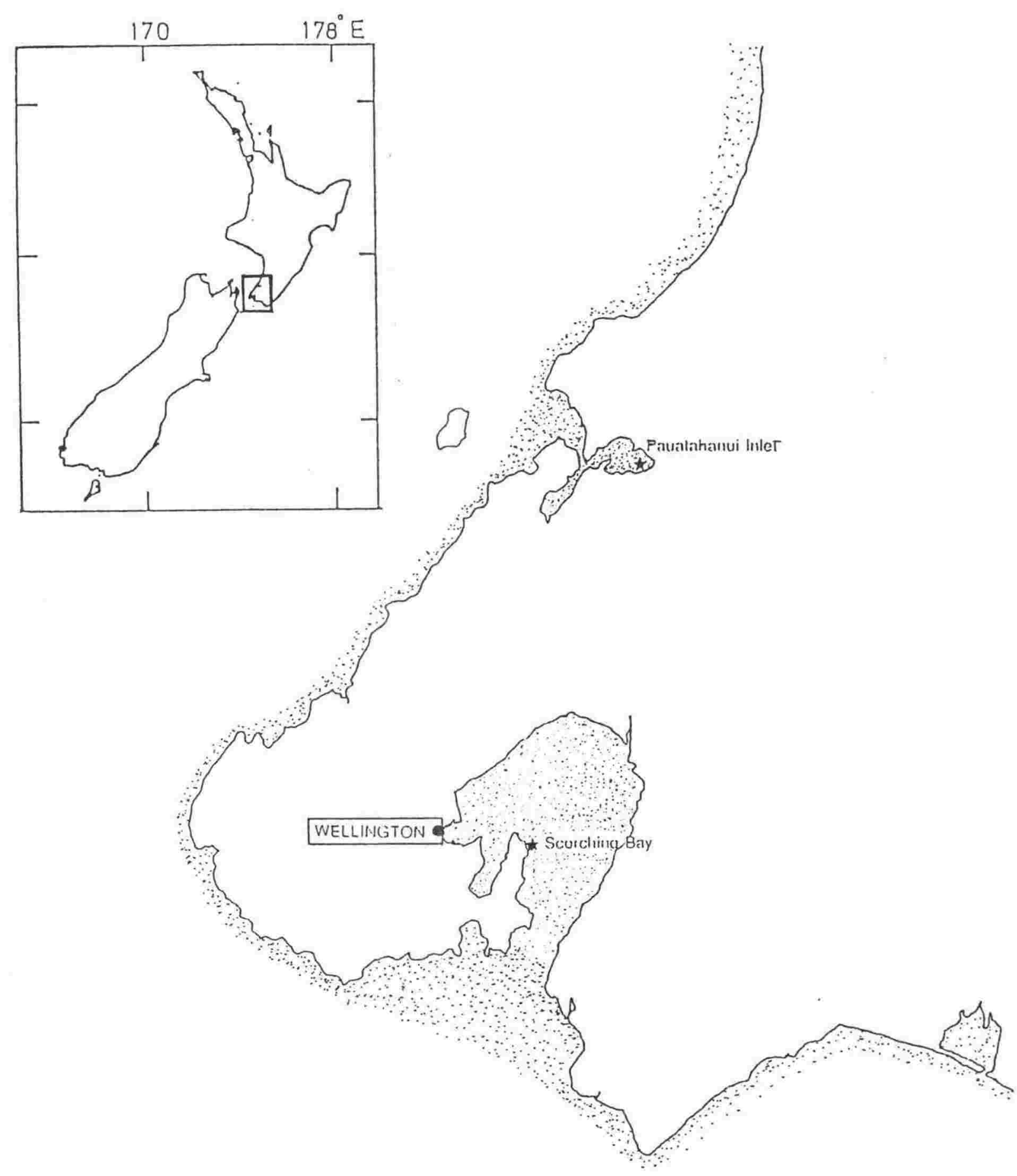

Figure 2.1. Map of the North Island, New Zealand, showing the collection sites for the sporulation study $(\star)$ 


\subsubsection{Environmental factors.}

Plants were collected during low tide periods and placed in an insulated box for transport to the laboratory. Within about $3 \mathrm{~h}$ of collection, the plants were carefully examined with a microscope and cystocarpic and tetrasporic plants were separated for use in the experiments.

Plants were cleaned to remove epiphytes and washed in Millipore-filtered seawater. Thalli were selected for uniformity in size, colour, number of cystocarps per thallus and distribution of tetrasporangia on a mature plant. The tetrasporic plants were cut into segments $2 \mathrm{~cm}$ in length from one lateral branch from each of 4 plants (about $0.5 \mathrm{~cm}$ away from main axis) and lateral branch of the cystocarpic plants were also cut into segments approximately $2 \mathrm{~cm}$ in length bearing 4 cystocarps on each segment. For each condition tested, two replicate petri dishes $(9 \times 2 \times 1 \mathrm{~cm})$ were set up, each containing two segments placed on a glass slide $(n=4)$. Each petri dish contained filtered seawater $(40 \mathrm{ml})$ and was placed in a culture room with a $12: 12 \mathrm{~L} / \mathrm{D}$ photoperiod.

The environmental variables studied were salinity, temperature, light intensity and daily exposure time. Because of the sheer number of spores that would have to be counted, for logistic reasons it was not possible to examine all environmental variables simultaneously in the one experiment (combination of factors which promoted spore release). Accordingly one environmental condition was varied per experiment, the other conditions being held constant at values as close to the mean environmental conditions experienced by the Gracilaria populations under study as could be produced in the culture room.

The value of each environmental condition when it was not being varied was as follows:

1) Salinity: $35 \%$

2) Temperature: $15^{\circ} \mathrm{C}$.

3) Light intensity: $100 \mathrm{uE} \cdot \mathrm{m}^{-2} \cdot \mathrm{s}^{-1}$

4) Daily exposure time: $0 \mathrm{~h}$ 
Four experiments were conducted in each of which a different environmental condition was varied as follows:
1) Four levels of salinity $(5,15,25,35 \%)$
2) Four levels of temperature $\left(15^{\circ} \mathrm{C}, 20^{\circ} \mathrm{C}, 25^{\circ} \mathrm{C}, 30^{\circ} \mathrm{C}\right)$
3) Four levels of illumination $\left(50,100,150,200 \mathrm{xE} \cdot \mathrm{m}^{-2} \cdot \mathrm{s}^{-1}\right)$
4) Five levels of daily exposure time $(0,1,2,3,4 \mathrm{~h})$

Salinity was measured using a hand-held salinometer (ATAGO refractometer). Seawater (35\%o) was collected from Victoria University Marine Laboratory at Island Bay, Wellington. The lower salinities were obtained by dilution of seawater with distilled water. The range of temperatures was produced using a gradient table and monitored using a thermometer. Light intensity of the cool-white fluorescent light sources was measured with a LI-COR quantum photometer (model LI 185A) equipped with a flat disc quantum sensor (LI-190S). For exposure time, the thalli were exposed to the air in a closed petri dish at $15^{\circ}$ $\mathrm{C}$ in the culture room for distinct times of exposure ( $0 \mathrm{~h}, 1 \mathrm{~h}, 2 \mathrm{~h}, 3 \mathrm{~h}$ and $4 \mathrm{~h})$.

Every $24 \mathrm{~h}$ during the treatments, the petri dishes were removed for counting of settled spores. The spores were counted with the help of a hand tally counter by observing the slides under a binocular low-power microscope. The seawater and slides were changed and the plants left to produce more spores. The procedure was repeated every day until the segments ceased spore discharge. The process of changing the seawater and slides were changed as quickly as possible in order to reduce subtle changes in environmental conditions. All media, slides and petri dishes used in these changes were kept in the cultured room to reduce the possibility of temperature shocks. The hourly total number of spores released over a $24 \mathrm{~h}$ period from the four segments was plotted on the graphs.

\subsubsection{Diurnal periodicity of spore discharge.}

The diumal periodicity of spore discharge, based on hourly counts over a period of 24 h, was also measured using plant segments as described above. They were held in petri 
dishes with $40 \mathrm{ml}$ of filtered seawater at a salinity of $35 \%$, at $15^{\circ} \mathrm{C}$ and $100 \mathrm{nE} \cdot \mathrm{m}^{-2} \cdot \mathrm{s}^{-1}$ 12:12 L/D photoperiod. Collection date for Pauatahanui Inlet weed and Scorching Bay weed for this experiment was on 23 and 26 May 1988, respectively.

\subsubsection{Spore size, spore germination and development.}

Tetraspores and carpospores obtained under standard environmental conditions, as mentioned above for daily spore counts, were allowed to settled on glass slides ( 4 slides) for one hours. A standard ocular micrometer was used to measure spore size, 50 spores were measured randomly from the dish of the first hour of daily spore counts. The sporelings were grown in petri dishes containing PES medium (Provasoli, 1968). Fresh medium was supplied weekly. General observations of spore germination and development were made using a microscope. If necessary, $5 \mathrm{mg}^{-1} \mathrm{GeO}_{2}$ was added to the medium to suppress growth of diatoms.

\subsubsection{Presentation of data and statistical Analysis.}

For each environmental condition tested, the mean cumulative spore outputs per segment, calculated at $24 \mathrm{~h}$ intervals, were recorded graphically using the Cricket Graph Programme for the macintosh Computer. For the first and the fifth day of each treatment, confidence intervals ( $\pm \mathrm{s} \times \mathrm{SD}$ ) were also plotted to assess differences between treatments in the kinetics of spore release. Where an error bar cannot be seen, the confidence limits fell within the dimensions of the data-point symbol. Confidence limits were also calculated for other 5 days to check the significance of kinetic differences.

Data of diurnal periodicity spore counts were also collected and the mean spore outputs per $2 \mathrm{~cm}$ segment $(n=4)$, were also recorded and calculated every hour.

The effects of each environmental on the total spore output per segment for the entire sporulation period were compared using pairwise t - tests (fuller, 1976) and differences were considered significant if the probability (p) $>Z<0.05$ (see Appendix 2, page 203). Pairwise in this thesis refers to two independent random samples (not matched pairs) as in many 
samples of an ANOVA. A discussion of the central limit theorems due to Lindeberg and Liapounov can be found in Fuller (1976). These theorems state that, under quite mild conditions (roughly symmetric distributions, with roughly equal variances), the standardized score of the sum (or mean) of a sequence of differentially distributed but independent random variables, will tend to follow the standard normal distribution. Fuller (1976) also extends his discussion to cases where the independence requirement can be relaxed somewhat for stationary time series (Renner, pers comm,).

\section{2:3. RESULTS.}

\subsubsection{Effect of salinity.}

The effects of salinity on spore release are shown in Figure 2.2. and Figure 2.3.

The salinity range that gave the greatest carpospore release for the weed from Pauatahanui Inlet was 15 - $35 \%$. The total carpospore output over this range of salinities did not show a clear difference, although at $35 \%$, carpospore release was slower and went on for longer (49 days). For the weed from Scorching Bay, the greatest output rate of carpospores also occurred at $15 \%$. and $25 \%$. while there was a smaller total output at 35 \%. A salinity of $5 \%$ had a detrimental effect on both the release and survival of carpospores of weed from both localities. Some spores were released but all of them burst shortly afterwards. Overall the releasing of carpospores for Gracilaria sordida from Pauatahanui Inlet and Scorching Bay extended over 40 days and 20 days, respectively. The number of spores released per day increased during the first 5 - 8 days of the experiment, then decreased.

For tetraspores, the greatest total output of spores was found at $15 \% \circ$ for the weed from both sites. A salinity of $5 \%$ had the same detrimental effect on tetraspores as for carpospores. For both populations, the releasing of tetraspores lasted only about one week and the maximum number of spores released per day occurred in the first and second day only. 

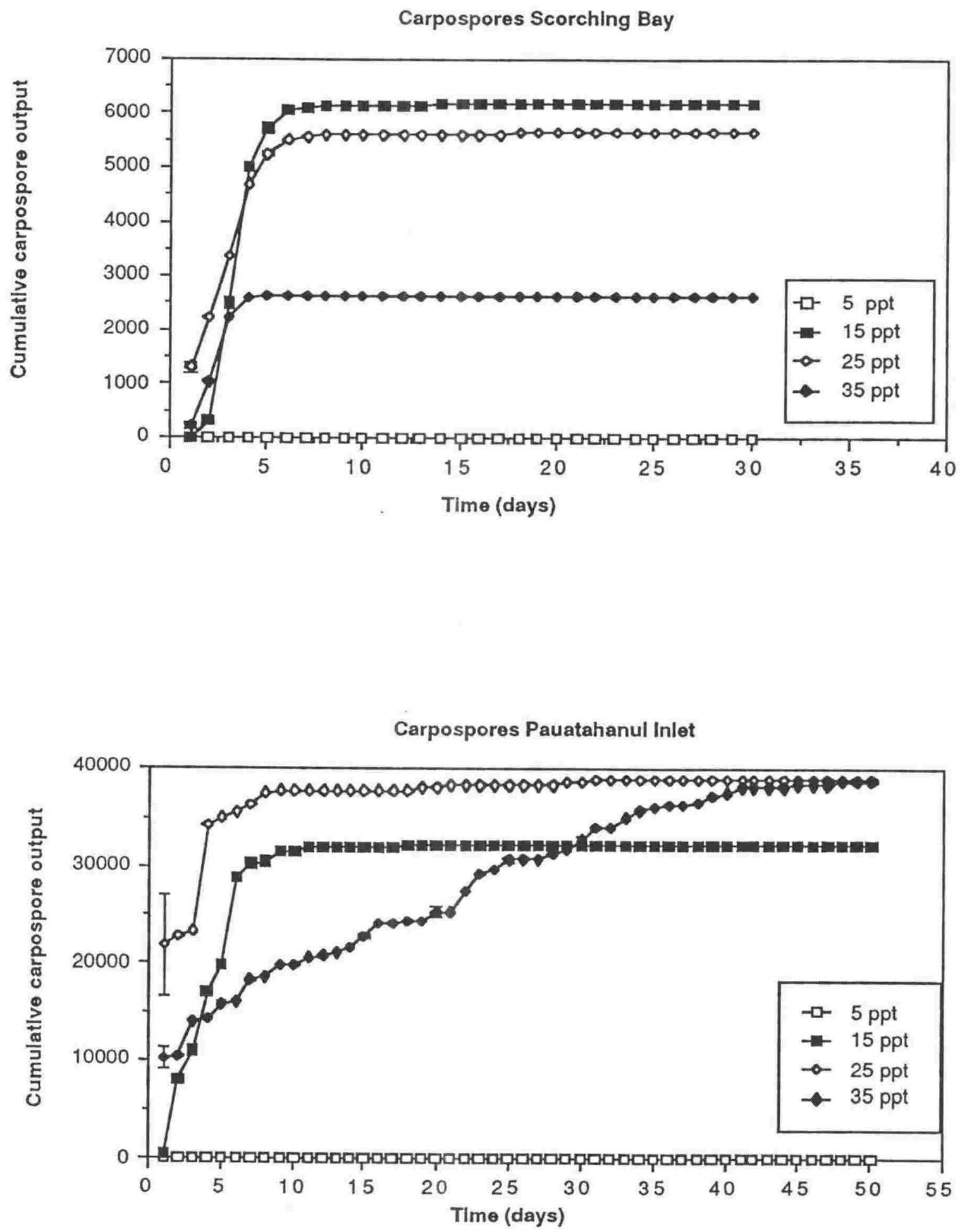

Figure 2.2. The cumulative spore output as a function of salinity. Vertical bars represent $95 \%$ confidence limit (mean $= \pm 2 \times \mathrm{SD}$ ). 
Tetraspores Scorching Bay

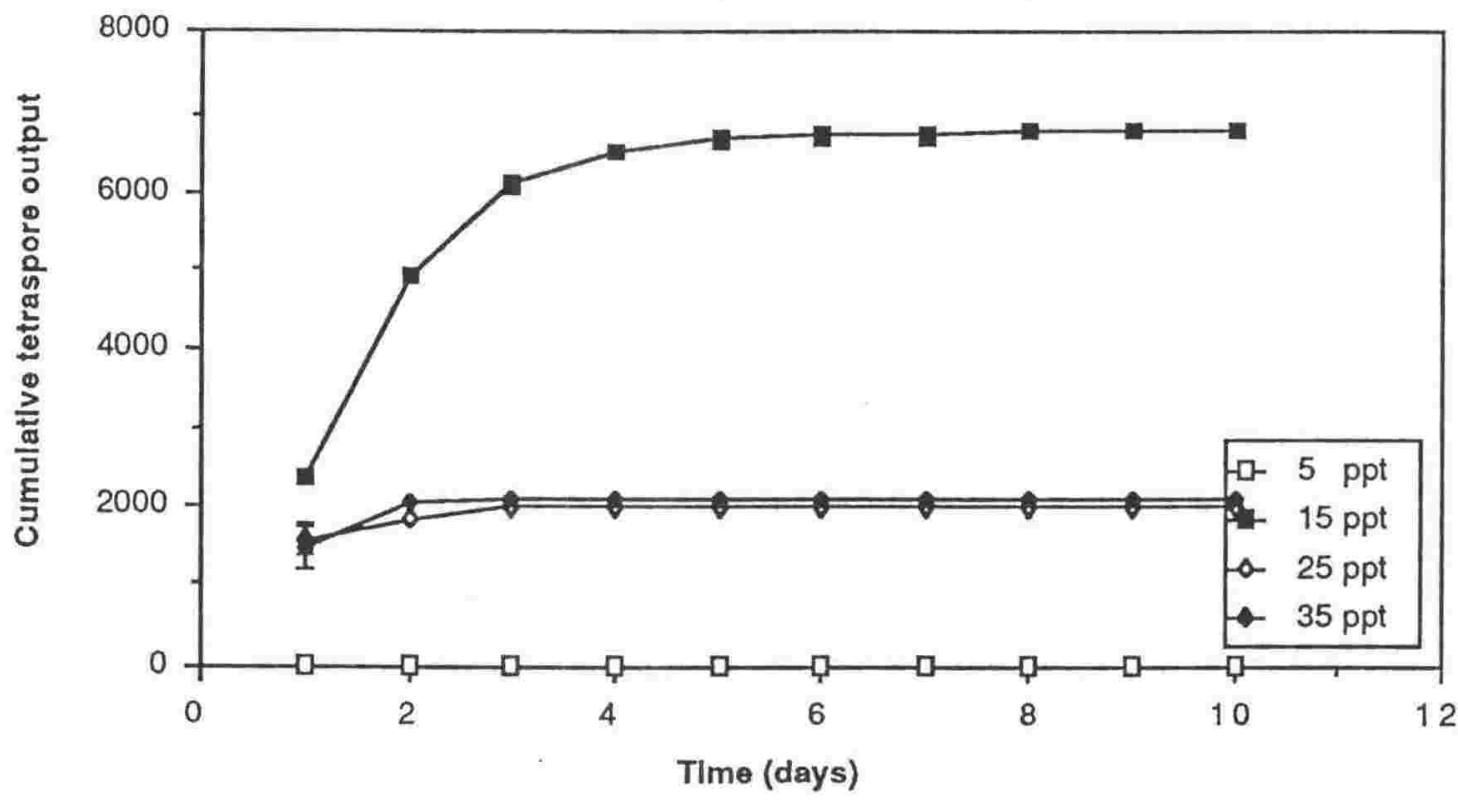

Tetraspores Pauatahanul Inlet

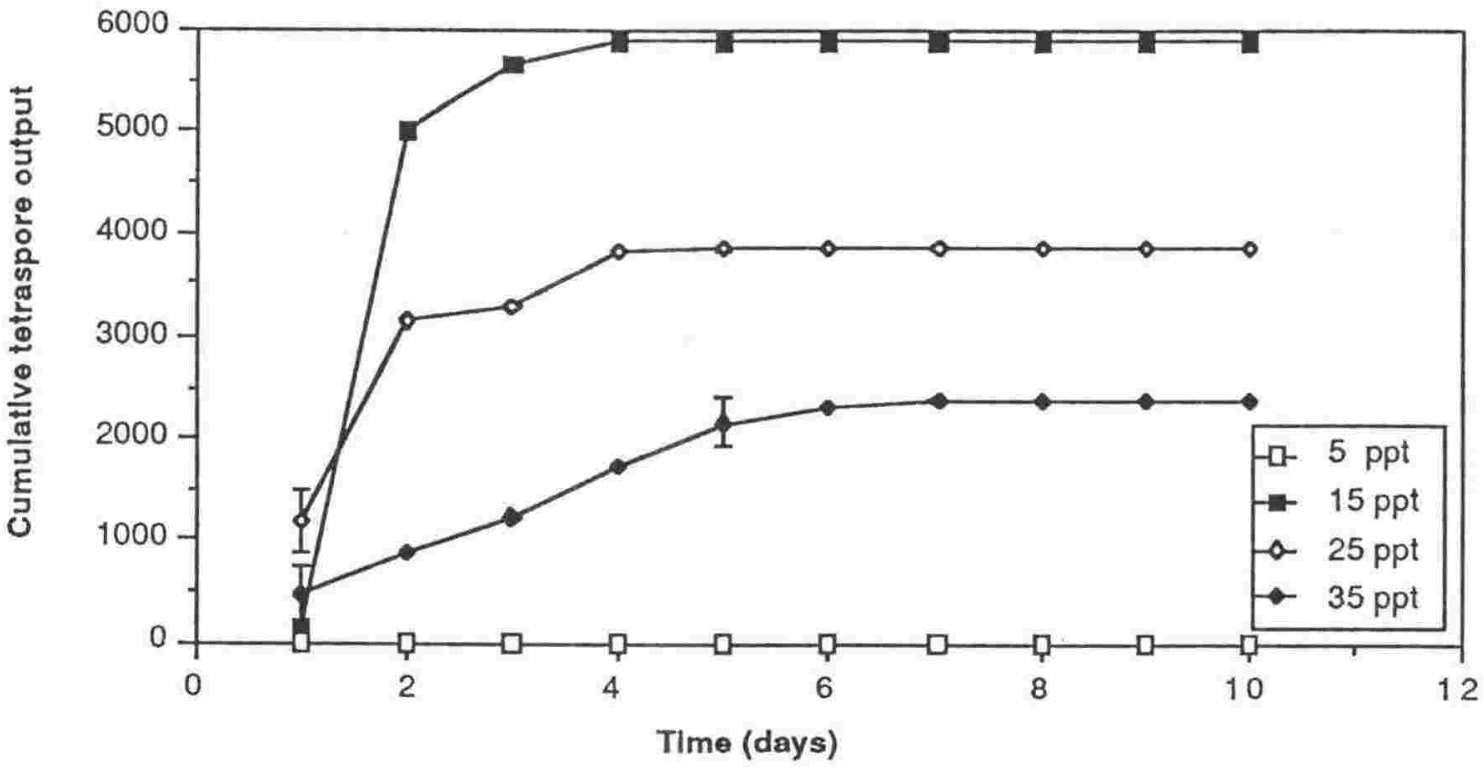

Figure 2.2. (Continued) 

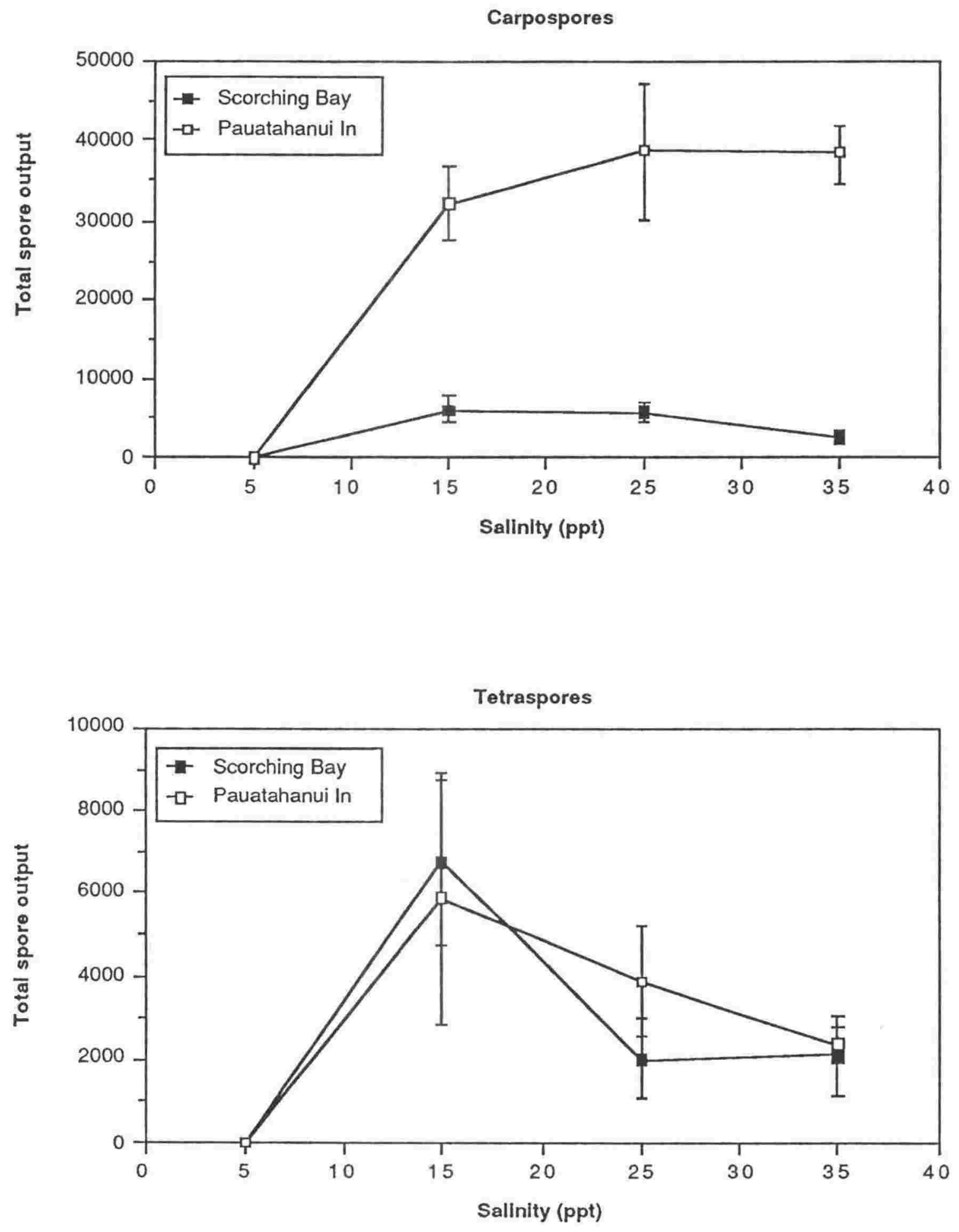

Figure 2.3. The total spore output as a function of salinity. Vertical bars represent $95 \%$ confidence limit $($ Mean $= \pm 2 \times \mathrm{SD})$. 


\subsubsection{Effect of temperature.}

The effects of temperature on spore release are presented in Figure 2.4. and Figure 2.5.

The greatest total carpospore output from the Scorching Bay weed occurred at $15-20^{\circ}$ $\mathrm{C}$ and from Pauatahanui Inlet at $15^{\circ} \mathrm{C}$. These lower temperatures $\left(15-20^{\circ} \mathrm{C}\right)$ also gave the longest releasing period (70 - 80 days). (The graphs in Figure 2.4. stop at 60 days because of the limitation of the Cricket Graph Programme that the more data that are plotted on the X axis (days), the more the data-point symbols tend to overlap, making the graph difficult to read; however the rates of any spore release beyond 60 days were slow). At temperatures of $25-30^{\circ} \mathrm{C}$, the segments of both carposporophyte and tetrasporophyte changed in colour from red-brown to pale green and ceased releasing spores after a short period. Thus, at a temperature of $25^{\circ} \mathrm{C}$, carpospore release ceased after $6-15$ days and at a temperature of $30^{\circ}$ C it ceased after only $3-6$ days.

For tetraspore release, the temperature range that gave the greatest carpospore release was $15-20^{\circ} \mathrm{C}$, although the period of releasing of tetraspores was shorter than for carpospores (about $10-15$ days) and the total number of tetraspores was less. 

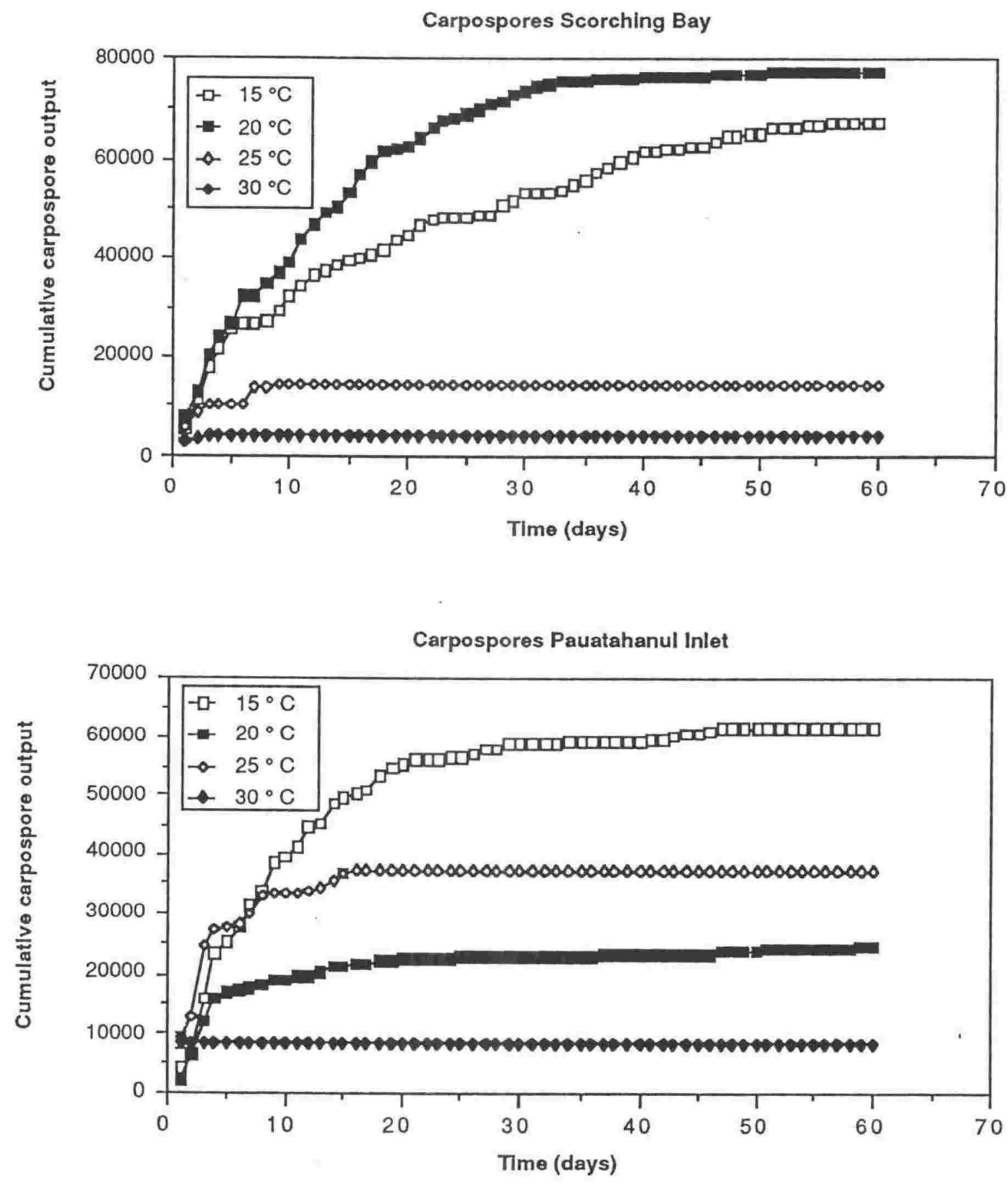

Figure 2.4. The cumulative spore output as a function of temperature. Vertical bars represent $95 \%$ confidence limit (Mean $= \pm 2 \times \mathrm{SD})$. 

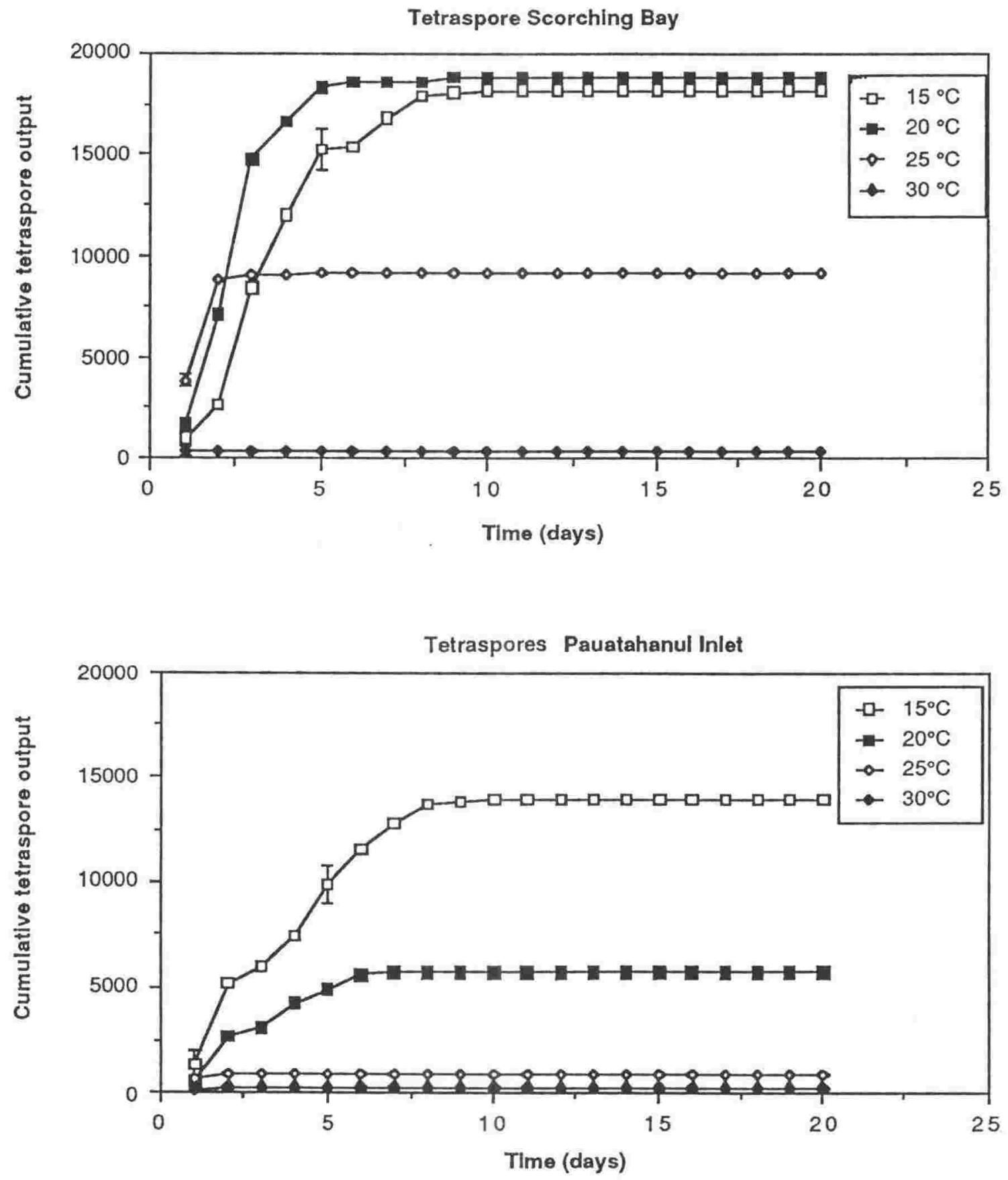

Figure 2.4. (Continued) 

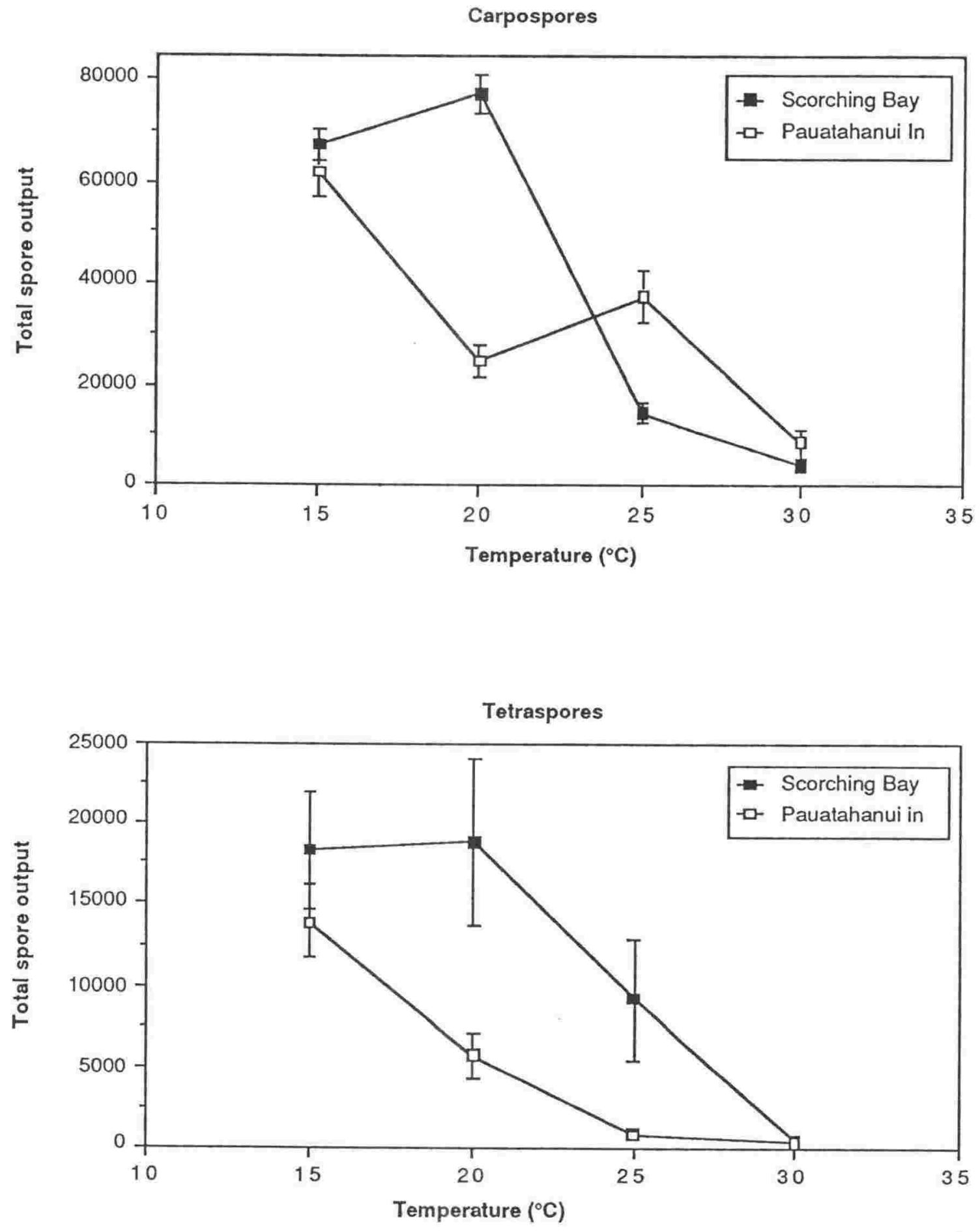

Figure 2.5. The total spore output as a function of temperature. Vertical bars represent $95 \%$ confidence limit (Mean $= \pm 2 \times \mathrm{SD})$. 


\subsubsection{Effect of light intensity.}

The effects of light intensity on spore release are shown in Figure 2.6. and Figure 2.7.

For the carpospores from Scorching Bay weed, the greatest total number of spores released occurred at the highest light intensity tested $\left(200 \mathrm{uE} \cdot \mathrm{m}^{-2} \cdot \mathrm{s}^{-1}\right)$. However, the total carpospore output at $50-150 \mu \mathrm{E} \cdot \mathrm{m}^{-2} \cdot \mathrm{s}^{-1}$ was high as well. For all these intensities, the duration of releasing of carpospores was nearly 2 months but the maximum output rate extended only from the first day to the fifth day of the experiment. For the weed from Pauatahanui Inlet, the light intensity that gave the greatest carpospore release was $50 \mathrm{uE} \cdot \mathrm{m}^{-2}$ $\mathrm{s}^{-1}$ and the releasing time lasted only 1 month.

The greatest total tetraspore output, from weed from both sites, also occurred at 150 $200 \mathrm{uE} \cdot \mathrm{m}^{-2} \cdot \mathrm{s}^{-1}$. The maximum output rate of tetraspores occurred during the first week of the experiment, then the releasing decreased, and ceased after 10 - 28 days. 

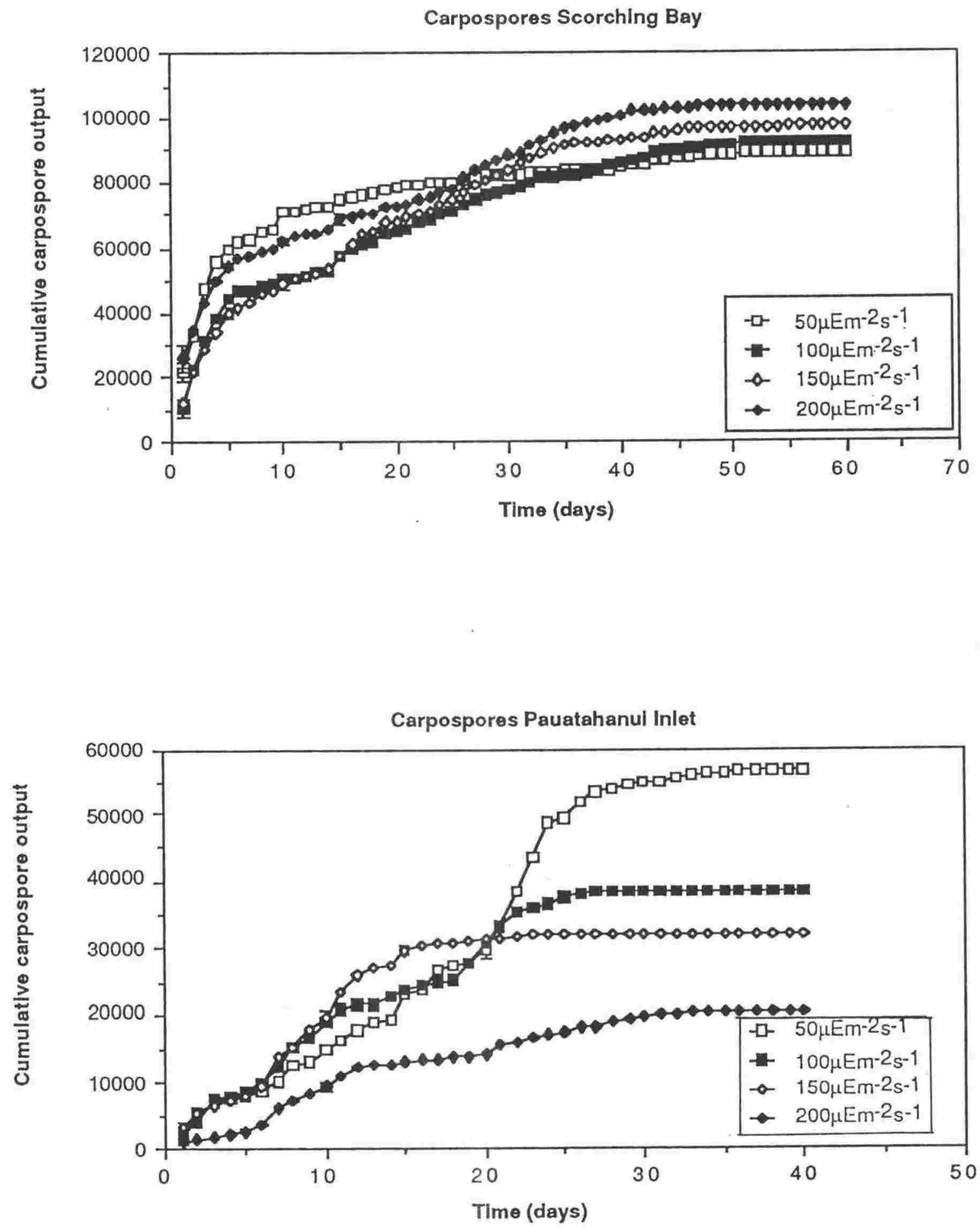

Figure 2.6. The cumulative spore output as a function of light intensity. Vertical bars represent $95 \%$ confidence limit $($ Mean $= \pm 2 \times \mathrm{SD})$. 
Tetraspores Scorching Bay

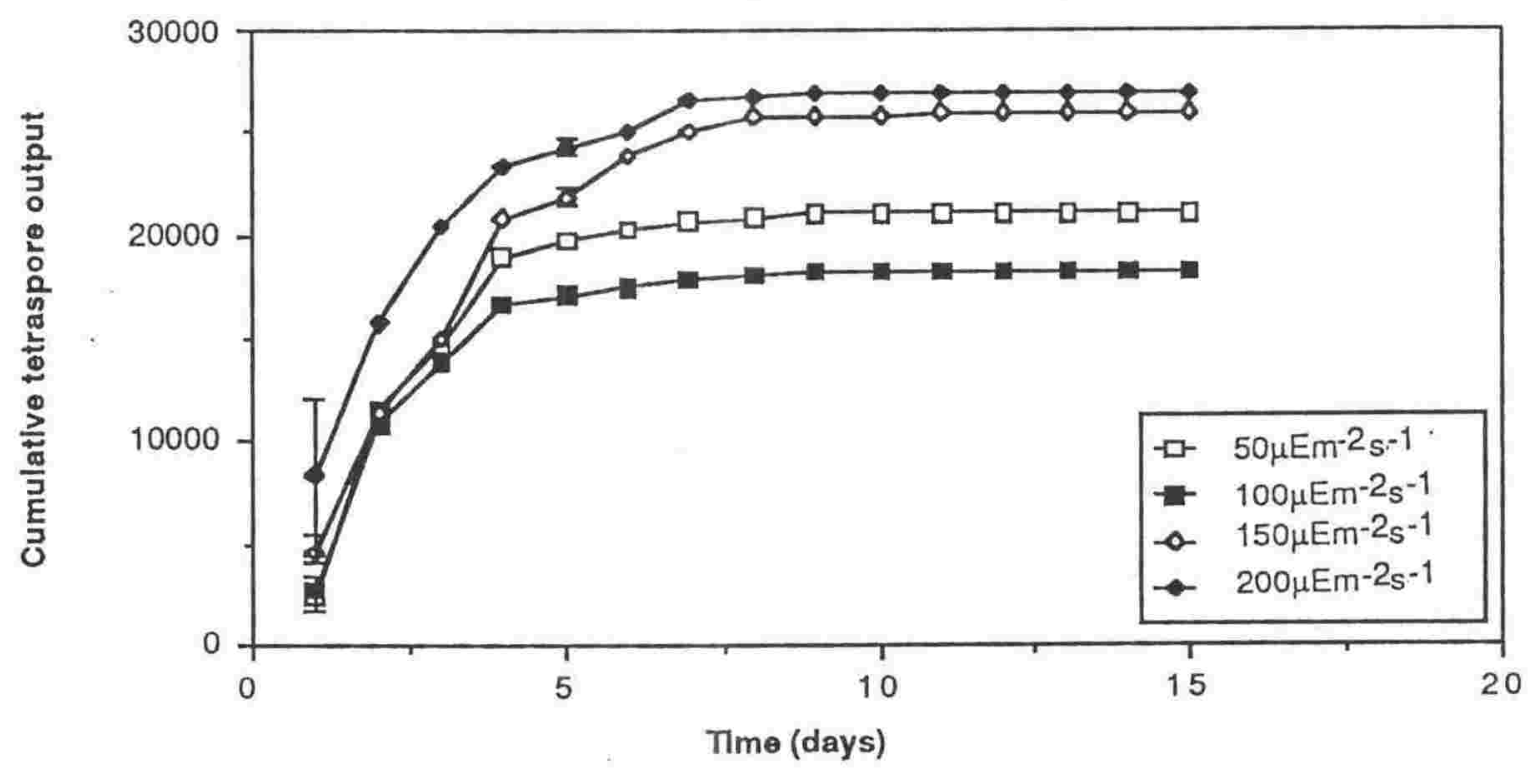

Tetraspores Pauatahanul Inlet

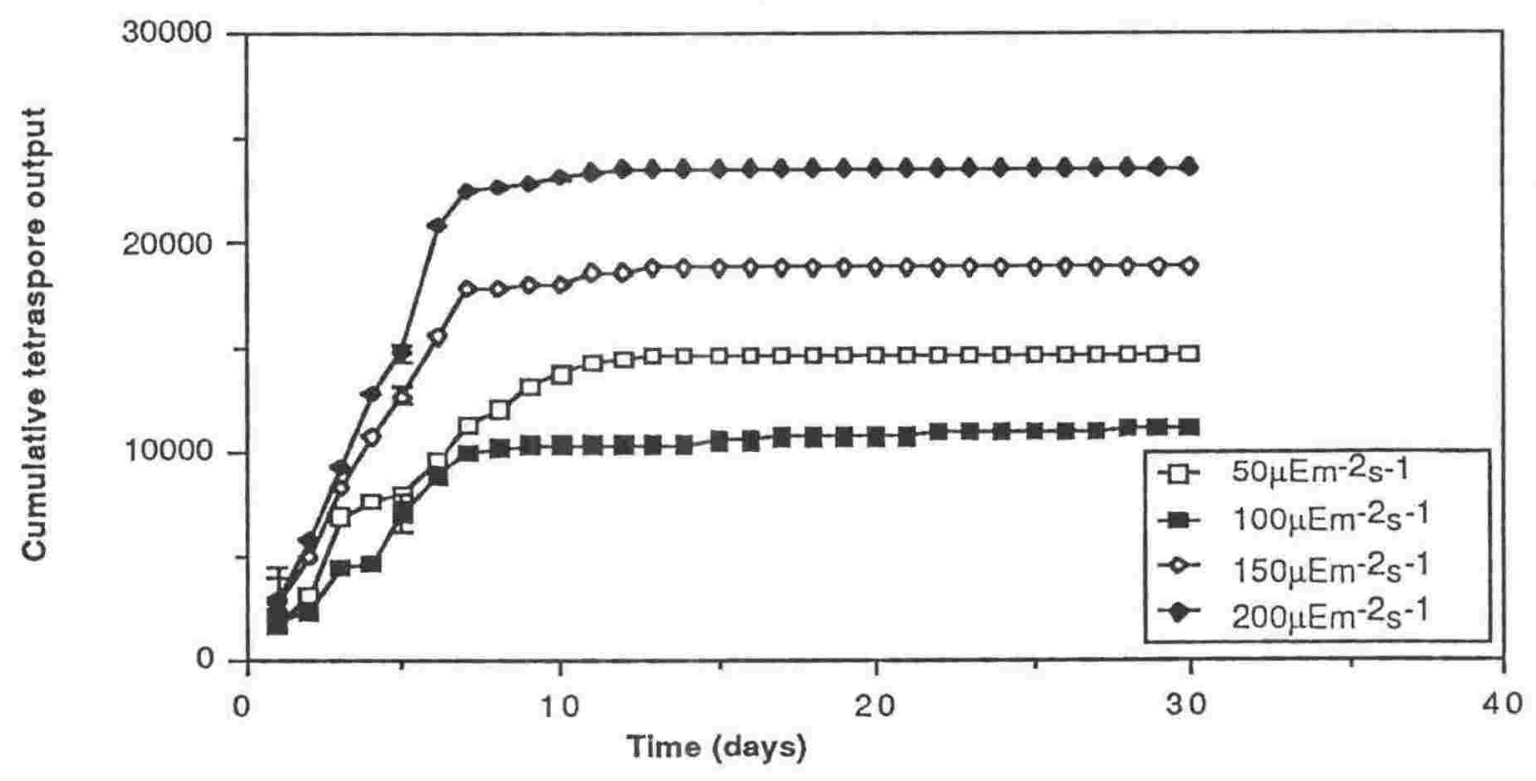

Figure 2.6. (Continued) 

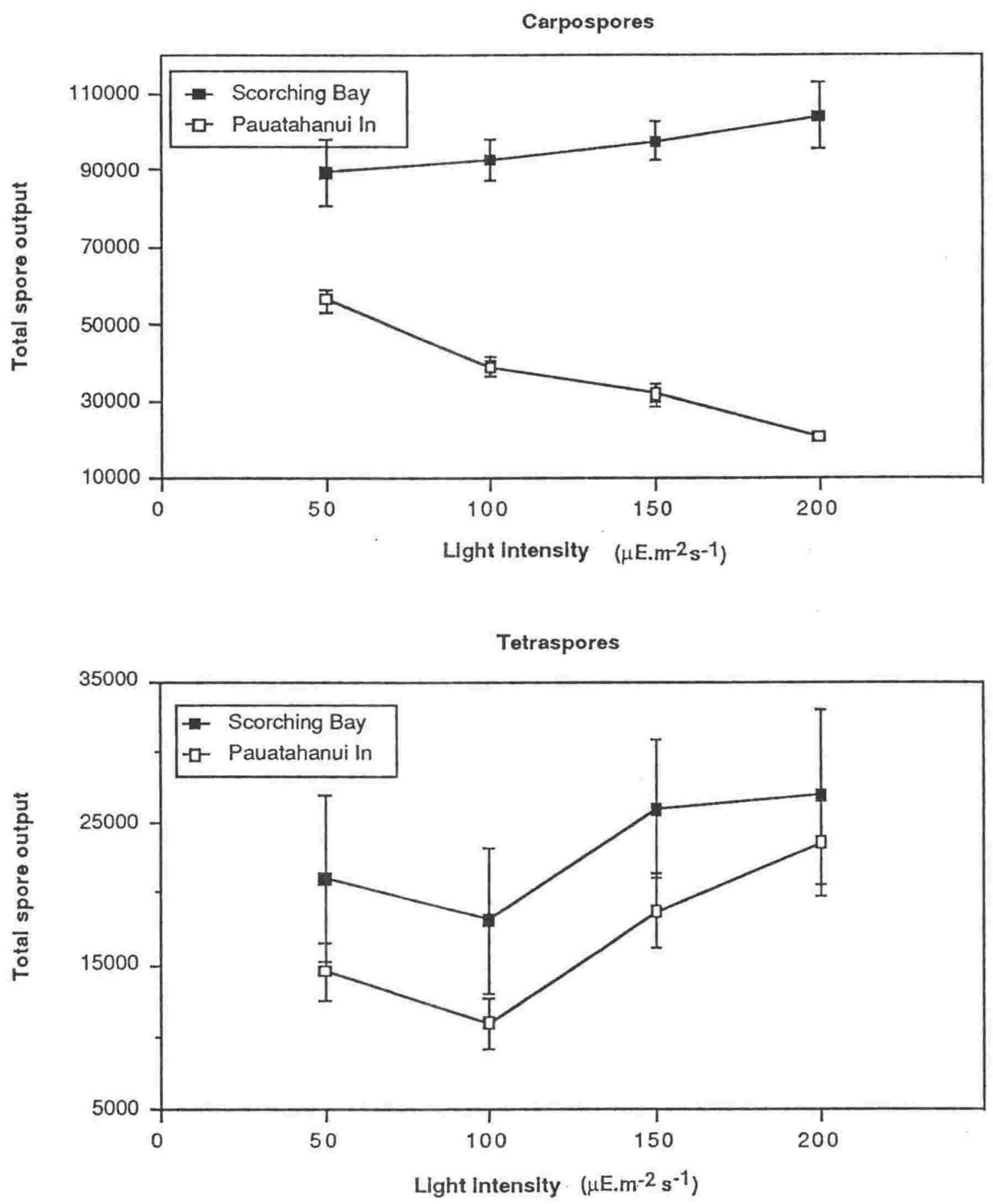

Figure 2.7. The total spore output as a function of light intensity. Vertical bars represent $95 \%$ confidence limit (Mean $= \pm 2 \times \mathrm{SD})$. 


\subsubsection{Effect of daily exposure time.}

The effects of daily exposure time on spore release are shown in Figure 2.8. and Figure 2.9.

For plants from both sites, numbers of carpospores released were high in the segments exposed to water saturated air for 0 - $3 \mathrm{~h}$ daily. For the weed from Scorching Bay, a $3 \mathrm{~h}$ exposure time gave the highest carpospore output while for the Pauatahanui weed, a $2 \mathrm{~h}$ exposure time gave the highest carpospore output. The number of carpospores released from the segments of plants exposed for the longest time tested $(4 \mathrm{~h})$ was the lowest and the period of spore release extended for the shortest number of days when compared with shorter exposure time or not exposed at all. The duration of releasing time for carpospores from both populations was about 60 days.

For tetraspores, the greatest spore output for Scorching Bay weed occurred at $4 \mathrm{~h}$ of daily exposure time, and for the Pauatahanui Inlet population at $3 \mathrm{~h}$. The duration of releasing time from both populations was about 14 - 20 days. 

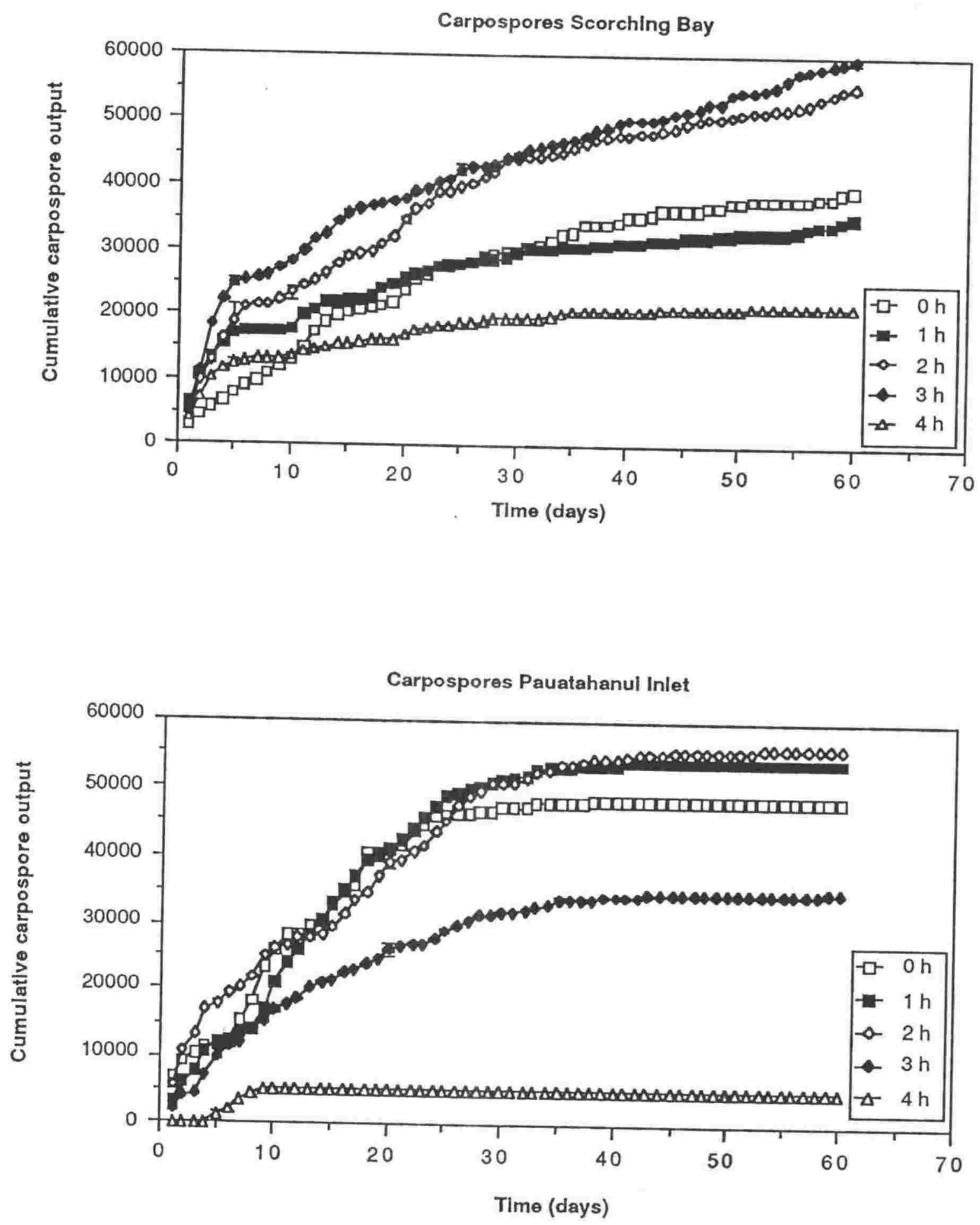

Figure 2.8. The cumulative spore output as a function of daily exposure time. Vertical bars represent ( $5 \%$ confidence limit (Mean $= \pm 2 \times \mathrm{SD}$ ). 

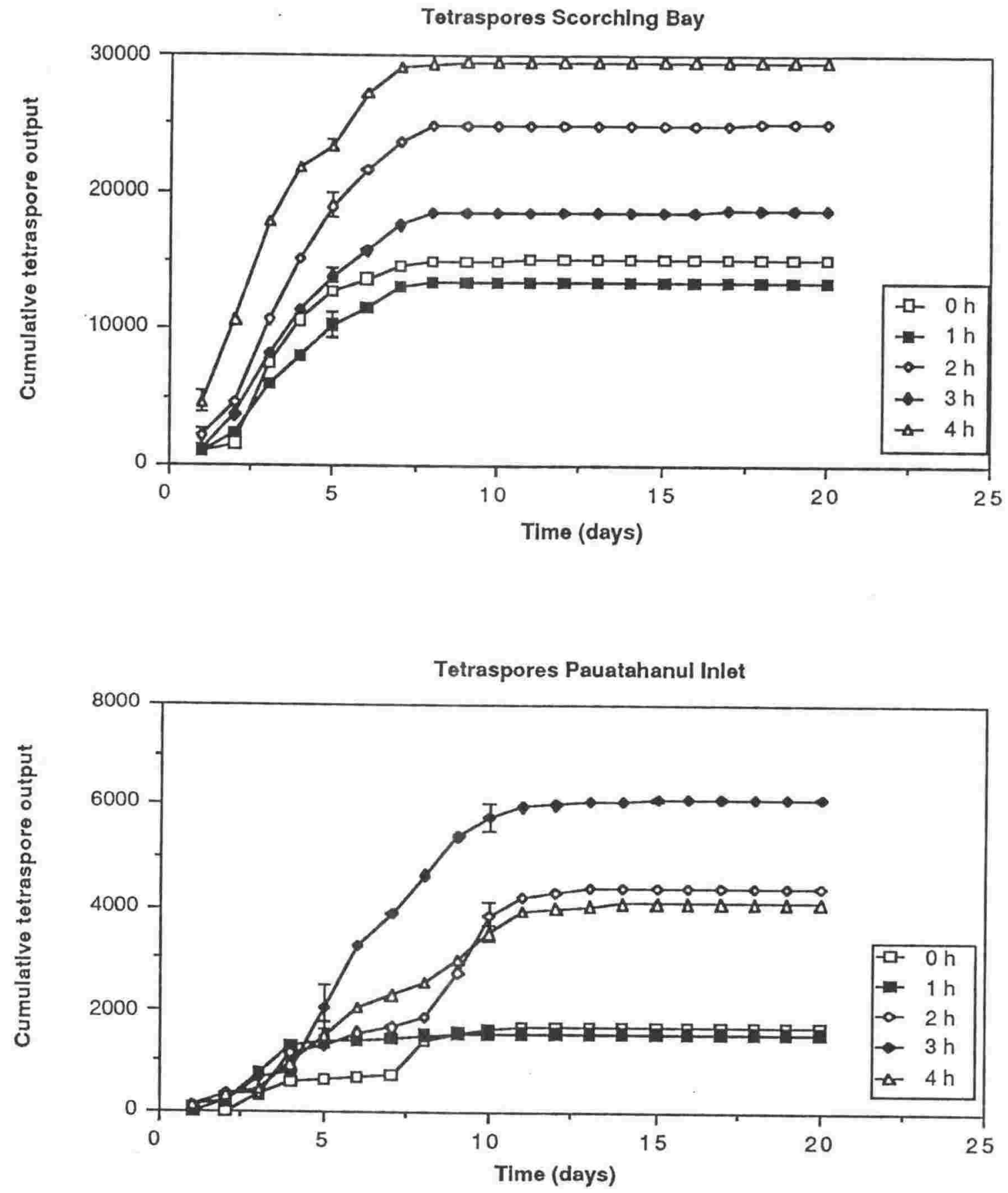

Figure 2.8. (Continued) 

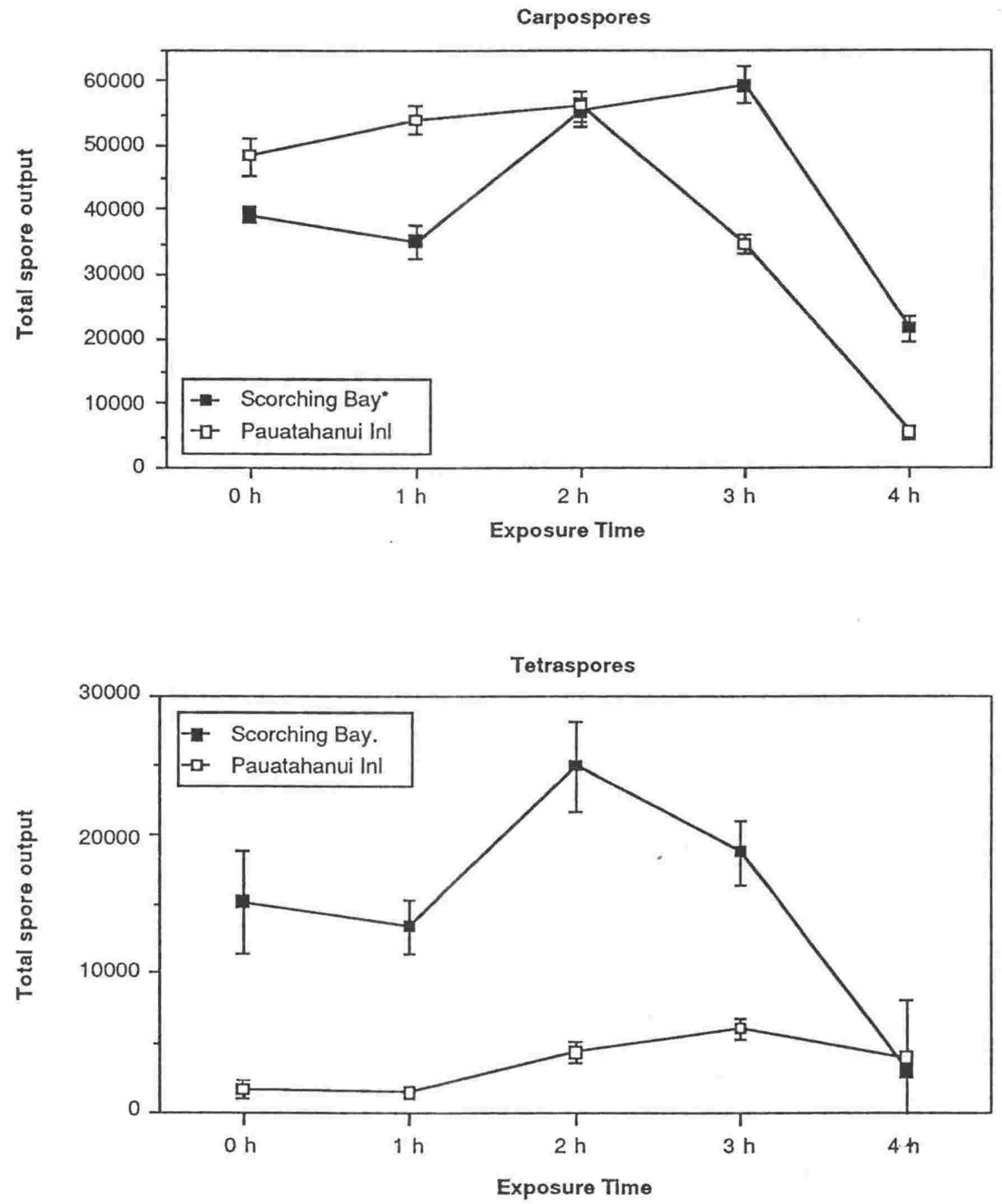

Figure 2.9. The total spore output as a function of daily exposure time. Vertical bars represent $95 \%$ confidence limit (Mean $= \pm 2 \times \mathrm{SD})$. 


\subsubsection{The diurnal periodicity of spore discharge over a period of 24 hours.}

The hourly recordings of total spore release over a $24 \mathrm{~h}$ period are shown in Figure 2.10 .

The pattem of spore discharge over a $24 \mathrm{~h}$ period was similar for both carpospores and tetraspores from both Scorching Bay and Pauatahanui Inlet weed (although the tetraspore output from Pauatahanui Inlet is so low that the graph does not show the pattern clearly), in that the greatest spore output took place in the morning (7:00 - 8:00 hours) and in the late afternoon (16:00 - 17:00 hours). The marked peak discharge of carpospores at the beginning of experiment $(1100 \mathrm{~h})$ for Scorching Bay might result from the effect of the tides or other environmental shocks. 
Scorching Bay
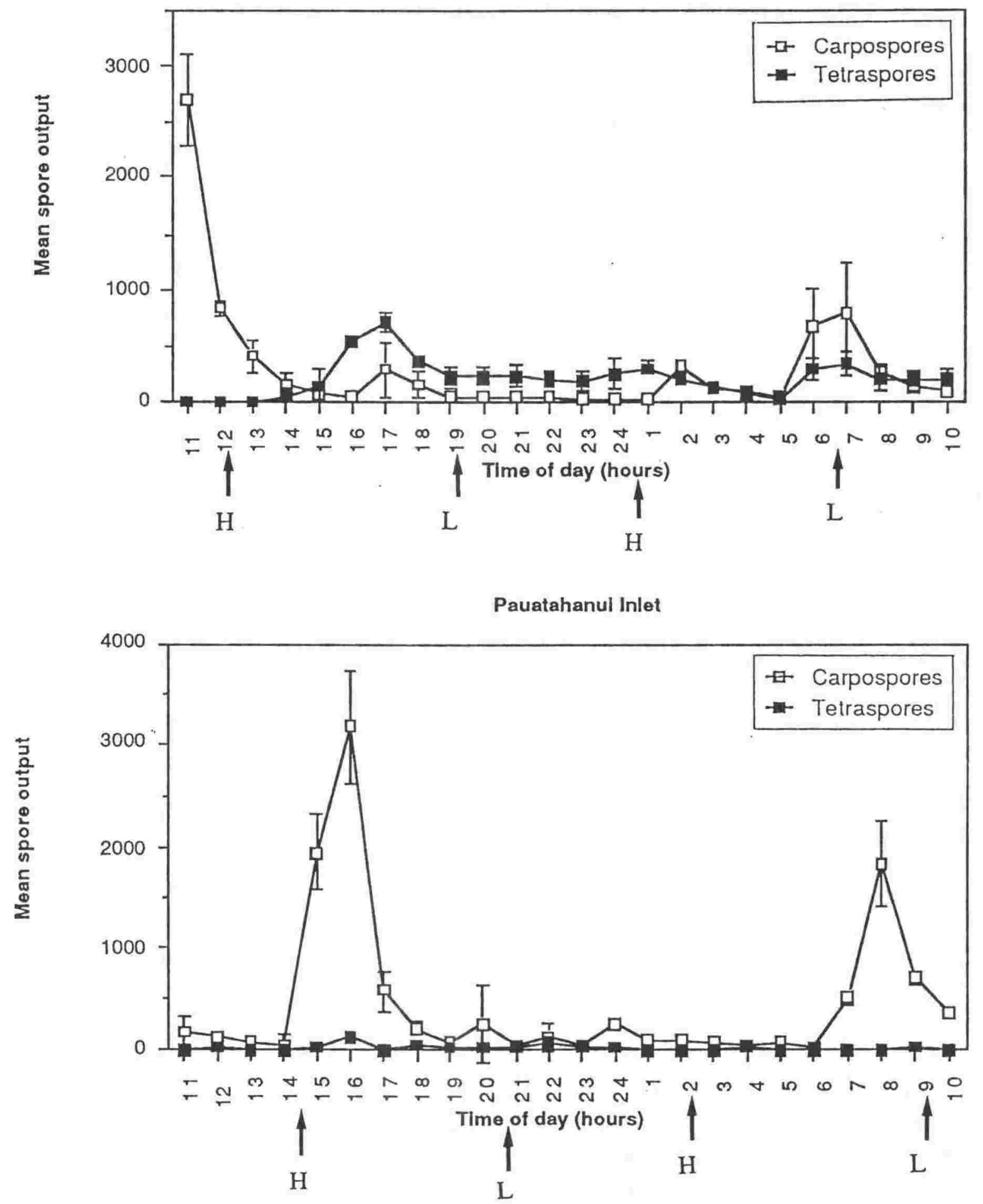

Figure 2.10. The variation of mean spore output over a $24 \mathrm{~h}$ period. Vertical bars represent $95 \%$ confidence limit $($ Mean $= \pm 2 \times \mathrm{SD}) . \mathrm{H}=$ high tide $\mathrm{L}=$ low tide 
2.3.6. Spore size, spore release, germination and development.

The size of carpospores and tetraspores from the two sites is presented in Table. 2.1.

Table. 2.1. Diameters (um) of released carpospores and tetraspores of Gracilaria sordida $(\mathrm{n}=50)$.

\begin{tabular}{|c|c|c|}
\hline Site & $\begin{array}{l}\text { Carpospores } \\
(\min ) / \text { mean } /(\max )\end{array}$ & $\begin{array}{l}\text { Tetraspores } \\
(\min ) / \operatorname{mean} /(\max )\end{array}$ \\
\hline $\begin{array}{l}\text { Scorching Bay } \\
\text { Pauatahanui Inlet }\end{array}$ & $\begin{array}{l}(30) / 42.1 /(60) \\
(30) / 41.4 /(55)\end{array}$ & $\begin{array}{l}(25) / 40.6 /(60) \\
(25) / 39.7 /(50)\end{array}$ \\
\hline
\end{tabular}

Spores released from mature cystocarpic and tetrasporic segments of $G$. sordida under different experimental conditions were essentially the same size (mean diameter ranged from $39.7-42.1 \mathrm{um}$ ) and shape. The mean diameter of spores ranged from $41-42 \lambda \mathrm{m}$ for carpospores and from $40-41$ um for tetraspores. The shapes of healthy released spores were generally spherical.

Cystocarpic segments not only produced more spores than tetrasporic segments but also discharged spores for a longer period. However, most spores are shed during the first week. Tetrasporangia occurred only on certain secondary or tertiary branches bearing a few or no lateral branchlets and spore maturation progressed from the base to the tip of the fertile branches.

Spore release, germination and development of G. sordida are illustrated in Plate 2.1. and Plate 2.2.

The germination patterns of carpospores and tetraspores were similar. The first cell 
division occurred within $24 \mathrm{~h}$ after settlement (Plate $2.2 \mathrm{a}-\mathrm{b}$ ). Within the first week the spores became segmented into cells and this was accompanied by an increase in size and germination discs were formed (Plate $2.2 \mathrm{c}$-d). Further periclinal divisions in the lower half of the sporeling initiated rhizoid formation (Plate $2.2 \mathrm{f}$ ). Within 2 weeks, a small primary erect frond was initiated from the central area of the disc (Plate $2.2 \mathrm{~g}$ ). The erect frond continued to elongate by continuous periclinal divisions and within a month numerous colourless hairs were formed along the surface of the frond (Plate $2.2 \mathrm{~h}-\mathrm{j}$ ). These hairs were conspicuous on young plants; on mature plants hairs were usually found on young branches (Bird et al., 1977). 

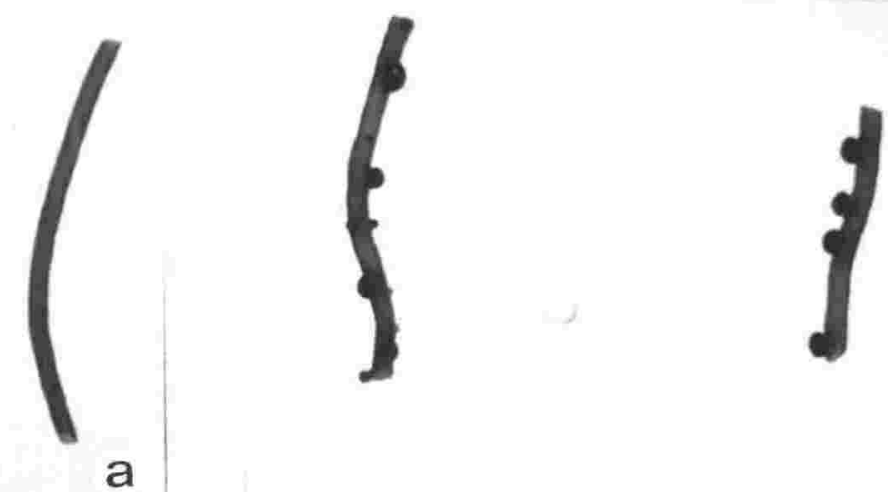

a
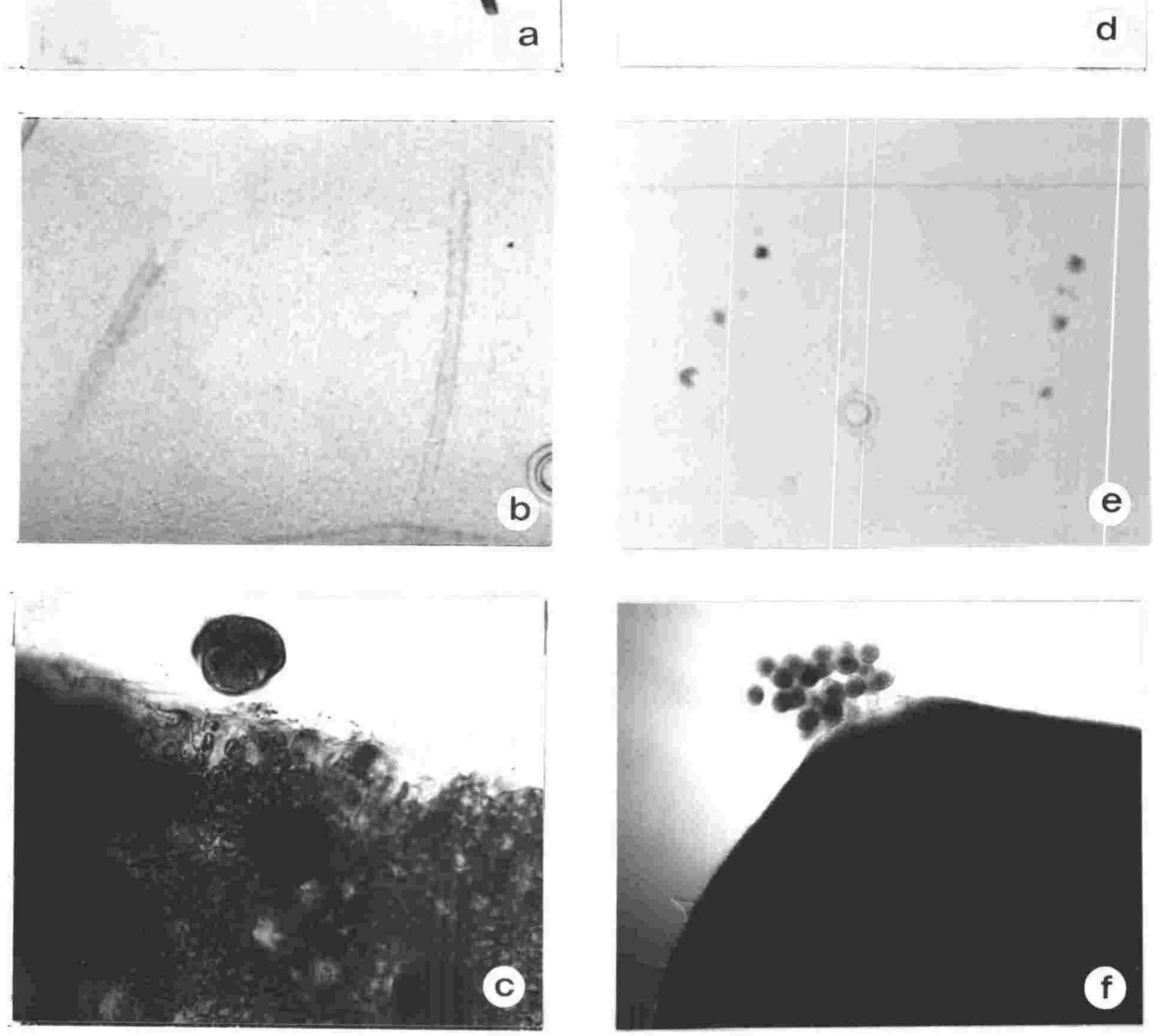

Plate 2.1. Spore release in Gracilaria sordida. a. Segments of tetrasporophyte bearing tetraspores. b. Pattern of tetraspores discharged. c. Tetraspore release. d. Segments of female gametophyte bearing cystocarps. e. Pattem of carpospores discharged. f. Carpospore release $(\mathrm{Bar}=1 \mathrm{~cm})$. 

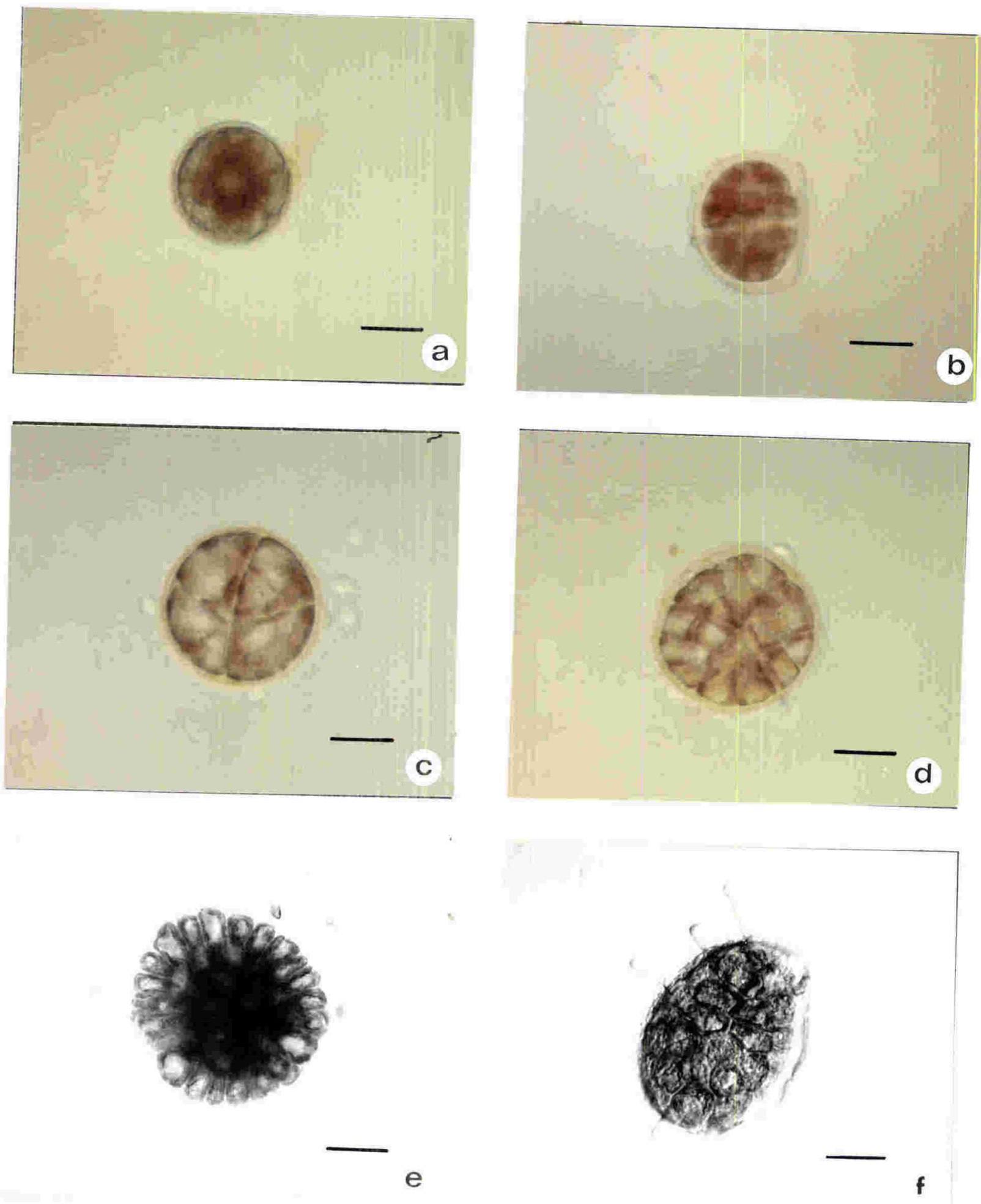

e

Plate 2.2. Successive stages in tetraspore development in Gracilaria sordida. a. Two-celled stage b. Four-celled stage c. Eight-celled stage d. Segmentation of the growing spore. e-f. Germination disc $(\mathrm{Bar}=20 \mathrm{um})$. 

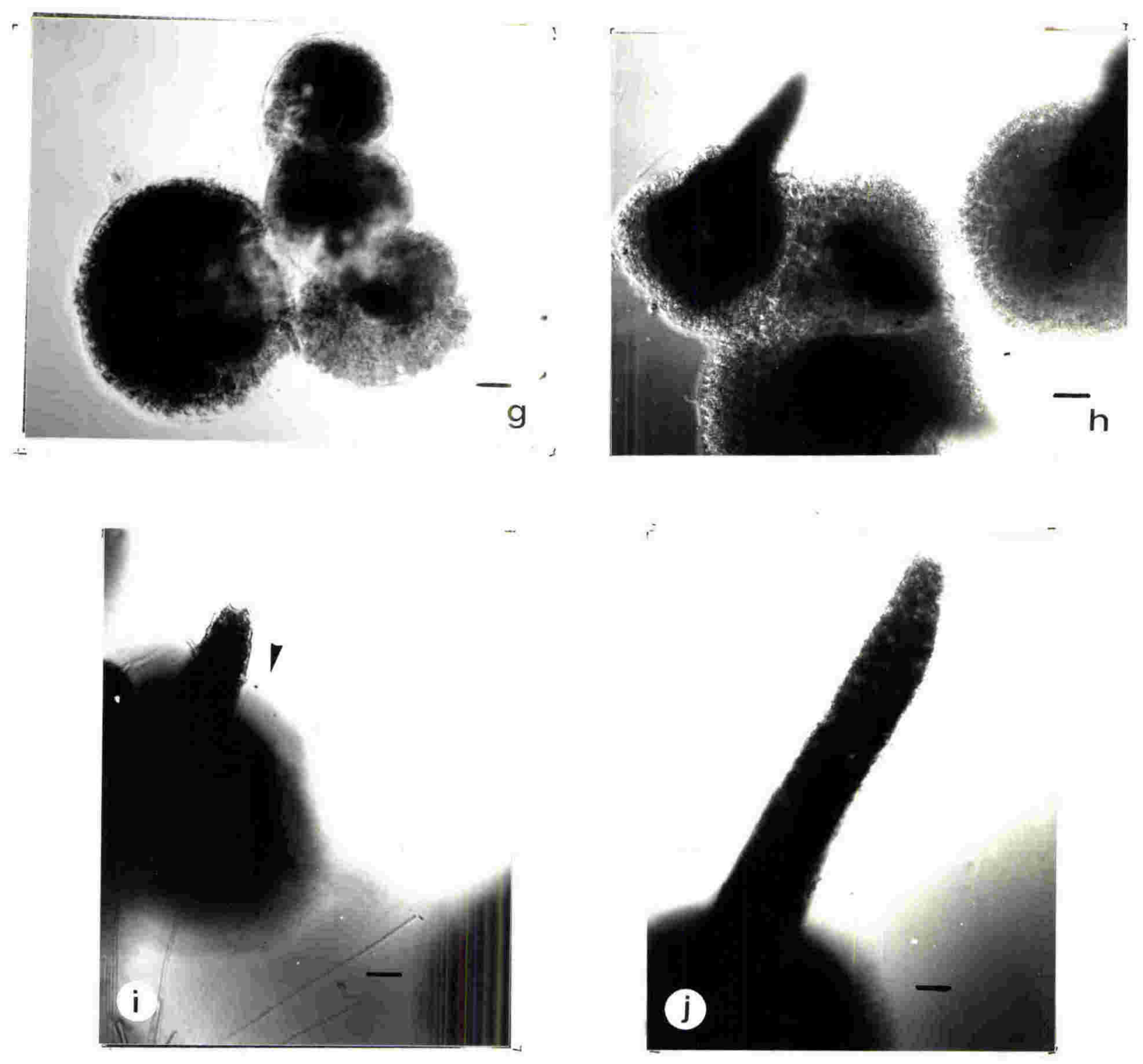

Plate 2.2. (Continued). g. Erect frond forming. h-j. Erect frond and hairs. 


\subsection{DISCUSSION.}

Ngan and Price (1979) investigated spore size in many red seaweeds (including Gracilaria) and found that mean carpospore diameter is larger than mean tetraspore diameter in most species. The present results (Table 2.1.) agree with the results of Ngan and Price (1979). Nelson (1987) reported that carpospore size of G. sordida is $25 \mathrm{um}-35 \mathrm{um}$ which is smaller than found in this study (41 - $42 \mathrm{xum}$ ). Lewmanomont (1987) studied carpospore size in Gracilaria firma in Thailand and reported that carpospore diameter ranged from 20 - $31 \mathrm{um}$. Ngan and Price (1979) suggested that variations in carpospore size might result from the collection of mature and immature spores and could be relate to adaptation for settlement and/or dispersal. Reported variations in tetraspore size might result from failure of cell division at meiosis (van der Meer, 1977).

Few investigators have counted the numbers of spores produced by seaweeds. Krishnamurthy (1965) reported that a single Gracilaria millardetii plant produces over 60,000 tetraspores and more than 40,000 carpospores. Oza and Krishnamurthy (1967) have calculated that $1.97 \times 10^{4}$ carpospores are released per mature female thallus of $G$. verrucosa. Kim (1970) reported that $G$. verrucosa liberates 200 - 2,000 carpospores from each mature cystocarp. Lewmanomont (1987) found that G. firma releases about 2,000 carpospores from each cystocarp depending on the age of the cystocarp and also reported that the duration of releasing lasted only 10 days. The present study indicates that in $G$. sordida about 2,300 - 3,000 carpospores can be liberated from each cystocarp and about 600 - 1,400 tetraspores can be produced from a fertile segment only $2 \mathrm{~cm}$ long. In fact, it is difficult to compare spore outputs of Gracilaria because different authors have used different methods and/or different units.

The periodicity of spore release has been recognized for many years. Seasonal, lunar, diumal, and tidal rhythms of spore release have been described (Oza and Krishnamurthy, 1967; Umamaheswara Rao, 1976). Variations in the seasonal spore output may be due to the different environmental conditions associated with each locality. 
From the experimental results described here, it can be concluded that the release of carpospores of $G$. sordida from Wellington, New Zealand has broad tolerances to salinity, light intensity and daily desiccation time. Such findings are similar to those described for the release of carpospores of Gracilaria verrucosa from China (H.Z.Y.Z., 1979), and from those of Lewmanomont (1987) for G. firma. In the latter study it was reported that exposure time $(1 \mathrm{~h}$ ) and salinity changes (from $30 \%$ to $15 \%$ ) promoted most carpospore release but light intensity and temperature did not.

A summary of the experimental conditions which produced most spore release in Gracilaria sordida is given in Table 2.2 .

Table 2.2 The experimental conditions which produced most spore release in Gracilaria sordida.

Factors

Carpospores

Tetraspores

Salinity (\%०)

15-35

15

Temperature $\left({ }^{\circ} \mathrm{C}\right)$

15-20

$15-20$

Light intensity $\left(\mathrm{uE} \cdot \mathrm{m}^{-2} \cdot \mathrm{s}^{-1}\right)$

50-200

150-200

Daily exposure time (h)

$1-3$

$2-4$

Spore production peaks

$6.00-8.00$

$6.00-8.00$

during $24 \mathrm{~h}$

$16.00-17.00$

$16.00-17.00$

Changing seawater salinities induced spore discharge in Gracilaria sordida. This is thought to be due to the changes in osmotic pressure gradients between the fertile sori and the medium (Kim, 1970).

The salinity which best promoted tetraspore and carpospore release of $G$. sordida were found to be around $15 \%$ and $15-35 \%$, respectively. These results agree with the results 
of Lewmanomont (1987) for G. firma. The maximum output of tetraspores in Gracilaria sjoestedtii, G. textorii and $G$. corticata was reported to be at 30,30 , and $40 \%$, respectively (Umamaheswara Rao and Subbarangaiah, 1981). Levine (1988) studied carpospore release of Gracilaria coronopifolia and G. parvispora in Hawaii and found maximum carpospore release at $29 \%$ and $35 \%$, respectively.

An increase in light intensity from $100 \mathrm{\mu E} \cdot \mathrm{m}^{-2} \cdot \mathrm{s}^{-1}$ to $200 \mathrm{\mu E} \cdot \mathrm{m}^{-2} \cdot \mathrm{s}^{-1}$ resulted in an increase in the number of spores released in G. sordida, but carpospores from Pauatahanui Inlet were an exception: for these, an increase in light intensity resulted in a decrease in the number of carpospores released. The carpospores of $G$. sordida has a broader tolerance to light intensity than tetraspores. Umamaheswara Rao and Subbarangaiah (1981) reported that increasing the light intensity from 32 to $42 \mu \mathrm{uE} \cdot \mathrm{m}^{-2} \cdot \mathrm{s}^{-1}$ resulted in a decrease in the number of tetraspores released in Gracilaria corticata, G. sjoestedtii, and G. textorii.

Suto (1950) hypothesized that spore shedding would occur when the water temperature reached a critical level for the species. Carpospore release in Gracilaria foliifera was negatively correlated with temperature (Friedlander and Dawes, 1984). Levine (1988) reported that the maximum carpospore release for Gracilaria coronopifolia and $G$. parvispora was $24^{\circ} \mathrm{C}$. High temperatures of $30^{\circ} \mathrm{C}$ (and sometimes $25^{\circ} \mathrm{C}$ ) were lethal to the Gracilaria sordida both carpospore and tetraspore, and also inhibited spore release, under the experimental conditions used.

The exposure time experiment demonstrated that a daily exposure to air $(2-3 \mathrm{~h})$ was beneficial to spore release. This finding agrees with results of spore release experiments with Gracilaria verrucosa from China (H.Z.Y.Z., 1979) and G. firma from Thailand (Lewmanomont, 1987). In the present study, the cystocarpic segments not only showed a wider tolerance to the length of desiccation time than did tetrasporic segments but released more spores also. In contrast to the present study, Umamaheswara Rao (1976) found that carpospores of Gracilaria corticata were not released after fertile thalli were exposed to air for one hour or more and no tetraspores were released after two or more hours of exposure. An increase in light intensity resulted in a decrease in the number of tetraspore released of 
G. corticata, G. sjoestedtii, and G. textori (Umamaheswara Rao and Subbarangaiah, 1981). The effects of exposure time are reduced when thalli are kept in the shade (Katada, 1955).

Overall, there was clear difference in the responses of $G$. sordida carpospore from the two sites in Wellington to salinity, temperature, light intensity and exposure time but tetraspore showed a clear difference response to temperature and exposure time only.

In the experiment concerning diumal periodicity of spore release, peak rates of spore output for both populations of G. sordida occurred at two periods on the day of the experiment, in early morning (6:00 - 8:00 hours), and in late evening (16:00 - 17:00 hours). However, it appears that in G. sordida marked periodicity may be a feature only of carpospore release (and possibly only at some locality) and coincided with the low tide in the morning and the high tide in the evening. Lunar rhythms of spore release have been studied by Ngan and Price (1983) in Australia. They report a higher ratio of mature to immature fruiting bodies during the two spring tide periods of the month. The release of carpospores during these periods coincided with the hide tide (Ngan and Price, 1983).

Records of diurnal periodicity in Gracilaria are variable. Maximum spore output was observed between 2:00 and 10:00 hours (Umamaheswara Rao, 1976; Ngan and Price, 1983). Umamaheswara Rao and Subbarangaiah (1981) found that the maximum output of carpospores and tetraspores for Gracilaria textorii occurred between 14:00 and 18:00 hours. Rangaiah (1985) reported that the maximum spore output for Gracilaria sjoestedtii occured between 2:00 and 6:00 hours and that this timing was not altered by changing the time of day, or the time of year, of collection. Levine(1988) reported that maximum carpospore output for Gracilaria coronopifolia occured between 23:00 and 7:00 hours and for $G$. parvispora occured between 3:00 and 7:00 hours. For G. firma from Thailand, the peak rate of spore output was found at night time (Lewmanomont, 1987).

The spore germination of $G$. sordida showed regular Dumontia type development in petri dish culture. This result agrees with the observations of Jones (1965), Bird et al. (1977), Levine (1988) and Lignell (1988). 


\subsection{CONCLUSION.}

In summary, the spore releasing of $G$. sordida showed a broad tolerance to salinity, temperature, light intensity and daily exposure time. This suggests that the seeding of spores onto substrates for mariculture could be induced by different environmental shocks and could be done as well as in the field and in the laboratory, and that for seeding, a duration of 7 days should be allowed for seeding before outplanting in order to obtain a large numbers of the spores.

This work is only preliminary. Spore release is only one aspect of reproduction that is relevant to mariculture. Other aspects such as spore production (seasonal patterm) and spore viability should be considered for further study. A repeat of experiment is necessary to check whether this result is reproducible and to check if the peaks of spore release still come morning and evening despite a change in the tide times. 


\section{CHAPTER 3}

\section{PILOT-SCALE CULTIVATION OF}

GRACILARIA SORDIDA.

\subsection{INTRODUCTION.}

The red seaweed genus Gracilaria has been considered a prime candidate for mariculture for various purposes including as raw material for production of agar, as biomass for methane production, as human and animal food, as fertilizer and as a nutrient scrubber for sewage treatment (Hanisak and Ryther, 1984; Lignell and Pedersen, 1986). The demand for Gracilaria has steadily increased during the past few years, while the supply from natural populations has not substantially increased. Moreover the wild crops are expected to collapse because of increasing harvesting, mismanagement and inadequate scientific knowledge (Santelices and Ugarte, 1987). Consequently, cultivation of Gracilaria has begun to supplement harvests from natural populations. Farming produces a crop that is not only more reliable in volume and quality, but also the volume can be expanded as the market increases (Brown et al., 1989; Santelices and Doty, 1989).

In New Zealand, Gracilaria sordida has been reported to be a potential source of food-grade agar and is also being used as a fodder for farmed abalone (Pickering, 1989). Thus, $G$. sordida has been the focus of active research that seeks to investigate the possibility of mariculture (Hollings, 1985).

Many types of Gracilaria cultivation have been tried worldwide including:

- Field culture (embayment) (Raju and Thomas, 1971; Hansen et al., 1984; Li et al., 1984; Ren et al., 1984; Smith et al., 1984; Santelices et al., 1984; Friedlander and Zelikovitch, 1984; Pizaro and Barrales, 1986; Camara Neto, 1987; Doty and Fisher, 1987). 
- Tank culture (Lapointe et al., 1976; Ryther et al., 1978; Lindsay and Saunders, 1980; Hansen et al., 1981; Johnson, 1981; Hanisak and Ryther, 1984; Edding et al., 1987).

- Pond and raceway culture (Shang, 1976; Chiang, 1981; Yang, 1982; Friedlander and Lipkin, 1982; Hansen, 1984; Rotmann, 1987).

- Spray culture (Moeller et al., 1984; Lignell and Pedersen, 1987; Pickering, 1990).

In each of these cultivation types, either vegetative material or spores can be used as planting material.

Most Gracilaria cultivation worldwide uses vegetative fragments as planting material. There is very little information regarding cultivation of Gracilaria using spores as planting material.

The spore method consists of seeding spores from selected fertile adult thalli onto a substrate suitable for outplanting. Spore cultivation of Gracilaria has been successful on an experimental scale in the West Indies, Malaysia and Thailand (Smith et al., 1984, Doty and Fisher, 1987; Mumford, 1987). However, the spores take about 4-6 months to grow into plants of harvestable size.

Many materials, including glass, plastic, asbestos, wood, slate, ceramic tiles, porcelain, string, net and rope have been used as artificial substrates (Foster, 1980). The substrate materials should of course not be toxic. Spore settlement and attachment may be affected by surface texture of the substrate materials; hence attachment may be improved by sanding or sand blasting the substrate to make a roughened surface.

In laboratory or large-scale field seeding operations, strings, ropes, or nets are generally used as substrate because they are widely available materials that are easy to handle (Mumford, 1979). These materials are full of crevices and grooves suitable for attachment, and seeded string or rope can be fastened to other structures for cultivation.

In spore-method culture, important steps are getting large quantities of spores at the 
proper time and having them released and dispersed so that they adhere to the substrate and develop as rapid as possible. It has been shown that spore release is affected by many environmental factors (see detail in Chapter 2).

The test farm functions were to establish:

1) The type of substrate materials best suited to methodology and local environment;

2) The relationships between environmental variables and growth rate of Gracilaria sordida.

3) The time span between spore set and first harvest.

The purposes of this study were:

1) To test the feasibility of cultivating of Gracilaria sordida using the sporulation techniques to seed the nets or ropes.

2) To obtain growth data for such plants grown in open-sea culture on a pilot scale.

3) To identify problems encountered in pilot-scale cultivation that warrant further research.

\subsection{MATERIALS AND METHODS.}

Small scale field cultivation experiments were conducted at Duck Creek, Pauatahanui Inlet ( $\left.41^{\circ} 06^{\prime} \mathrm{S}, 174^{\circ} 54^{\prime} \mathrm{E}\right)$ in Porirua Harbour for a one year period from January 1989 to January 1990.

\subsubsection{Description of farming site.}

Pauatahanui Inlet is a tidal estuary located in Porirua Harbour about $20 \mathrm{~km}$ north of Wellington on the lower North Island's west coast. Porirua Harbour is composed of two arms; Porirua Inlet (South-west arm) and Pauatahanui Inlet (Eastern arm). These are joined together by a narrow channel which is presently spanned by the State Highway 1 road bridge and a railway line and they share common access to the sea via a narrow channel. 
Pauatahanui Inlet has a total area of approximately $4.5 \mathrm{~km}^{2}$ about $1 \mathrm{~km}^{2}$ of which consists of tidal mud flats (Amarasuriya, 1976; Healy, 1980). The site selected for the pilot farm was at Duck Creek, located on the south-east of Pauatahanui Inlet. The intertidal zone there consists of fine sand and mud sediments, receiving run-off and fresh water from Duck Creek (see Figure 3.1). 

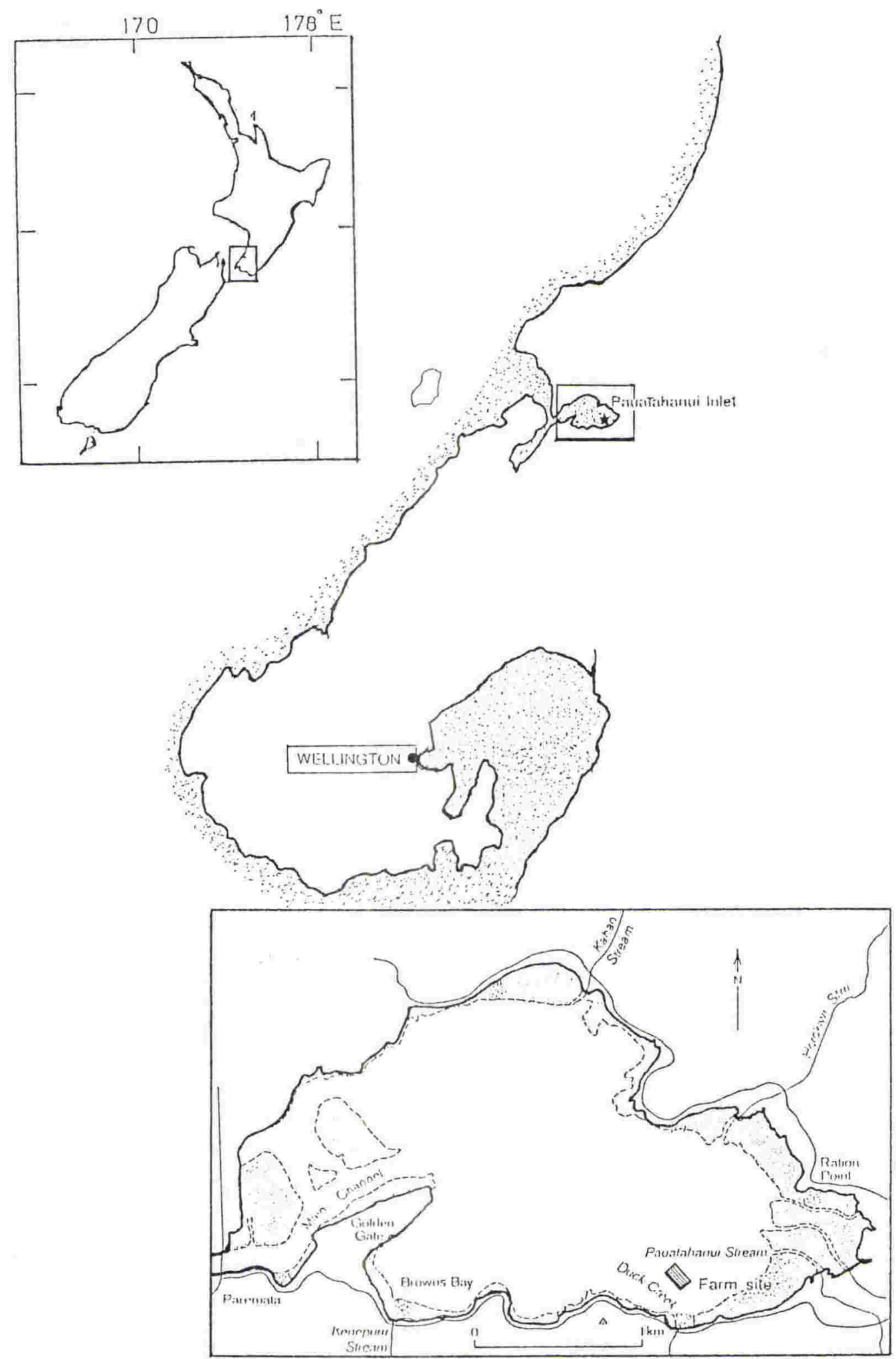

Figure 3.1. Map of New Zealand, and of Pauatahanui Inlet and the farm site ( $\square$ ). 
In Pauatahanui Inlet, tidal sea level exchange is semidiurnal and nearly symmetrical with a mean spring range of $1.25 \mathrm{~m}$ and a mean neap range of $0.4 \mathrm{~m}$. The farm site was covered with approximately $10 \mathrm{~cm}$ of water at the lowest tide and $1.50 \mathrm{~m}$ at the highest tide. All sand and mudflats have a low gradient, and are rapidly covered and uncovered during tidal fluctuations. Pauatahanui Inlet is subject to relatively high rates of sedimentation. The Harbour is in fact "filling up" naturally at a rate calculated to be about $2 \mathrm{~mm}$ to $3 \mathrm{~mm}$ per year (Healy, 1980).

\subsubsection{Farming materials.}

The pilot farm consisted of artificial substrates of net and rope attached to an anchored frame work.

The following were used as artificial substrates (Plate 3.1):

1) Wind-break net (high density polyethylene, $30 \mathrm{~cm}$ wide, $2 \mathrm{~m}$ long, mesh size 2 $\mathrm{mm})$.

2) Shade cloth (fibreglass, $30 \mathrm{~cm}$ wide, $2 \mathrm{~m}$ long, mesh size $3 \mathrm{~mm}$ ).

3) Polypropylene rope (Manline $6 \mathrm{~mm}$ diameter)

4) Sisal rope ( $8 \mathrm{~mm}$ diameter)

5) Christmas-tree mussel rope

6) Monofilament (nylon) line (0.7 mm diameter)

The components of the frame work consisted of:

1) Polypropylene rope (Manline $4 \mathrm{~mm}$ diameter)

2) Pear-shape floats ( $20 \mathrm{~cm}$ diameter)

3) Stakes (wood, 2 metre long)

4) Anchors (wood, 0.5 metre long)

All farming materials cited above including stakes and floats, except Christmas-tree mussel rope (from Mahanga Bay Shellfish Hatchery, MAF) were bought from Wellington Provedoring Co. Ltd, Seaview Store (Shed 1) Waterman Street, Seaview, Wellington. 
Two sets of each material were seeded and outplanted for experiment. Each set consisted of a line of five ropes or nets, each $2 \mathrm{~m}$ long, joined end to end. In each case four of the lengths were seeded and one was left unseeded as a control. 


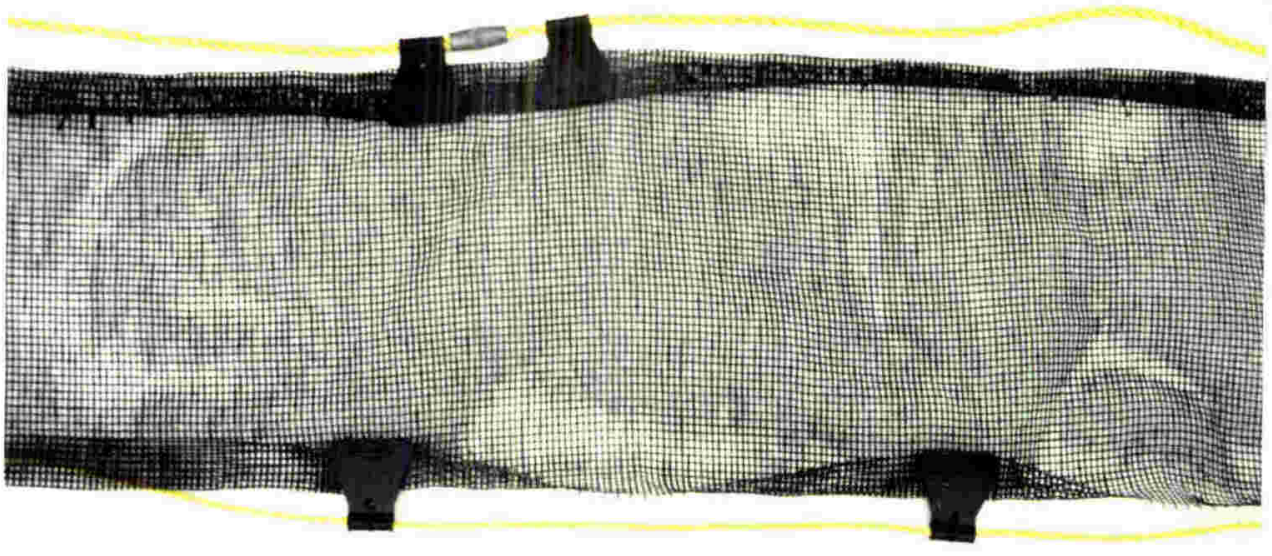

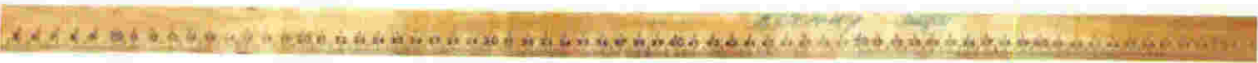

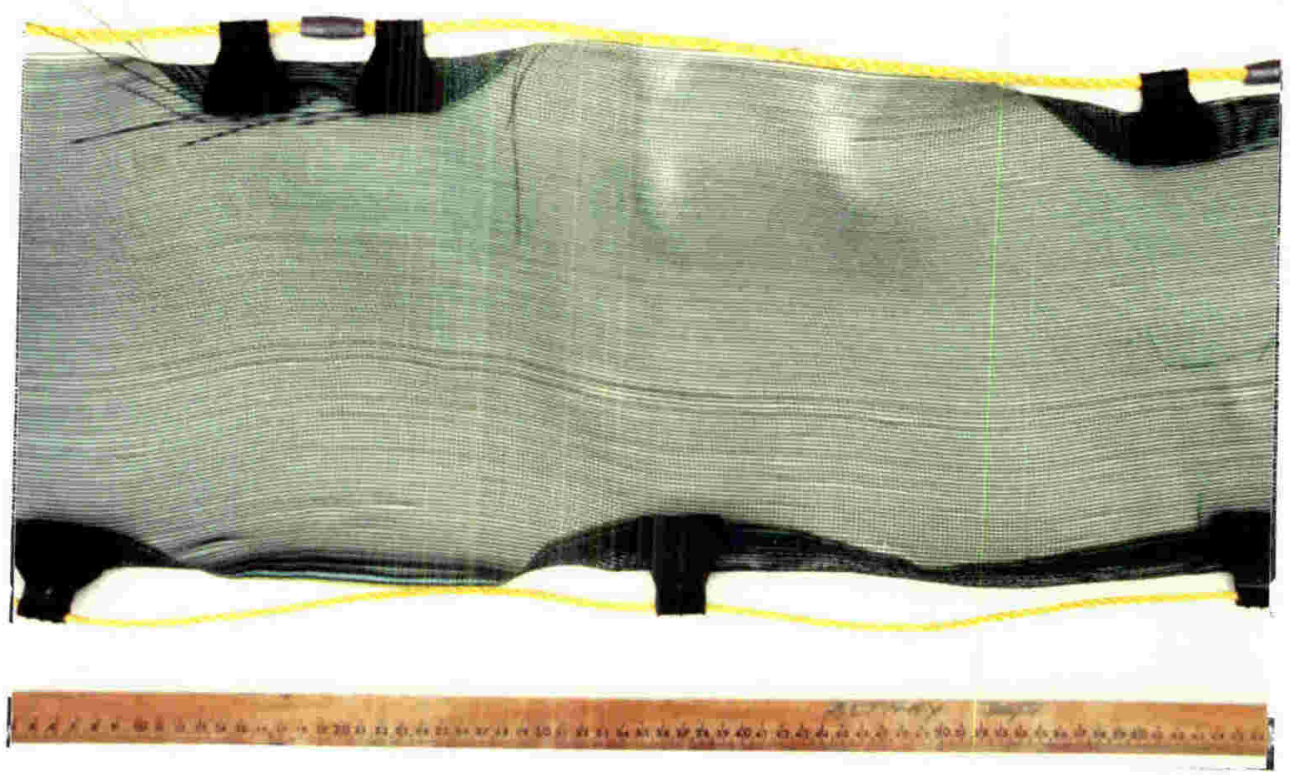

Plate 3.1. Artificial substrates used in cultivation of Gracilaria sordida from spores. a. Wind-break net b. Shade-cloth net 


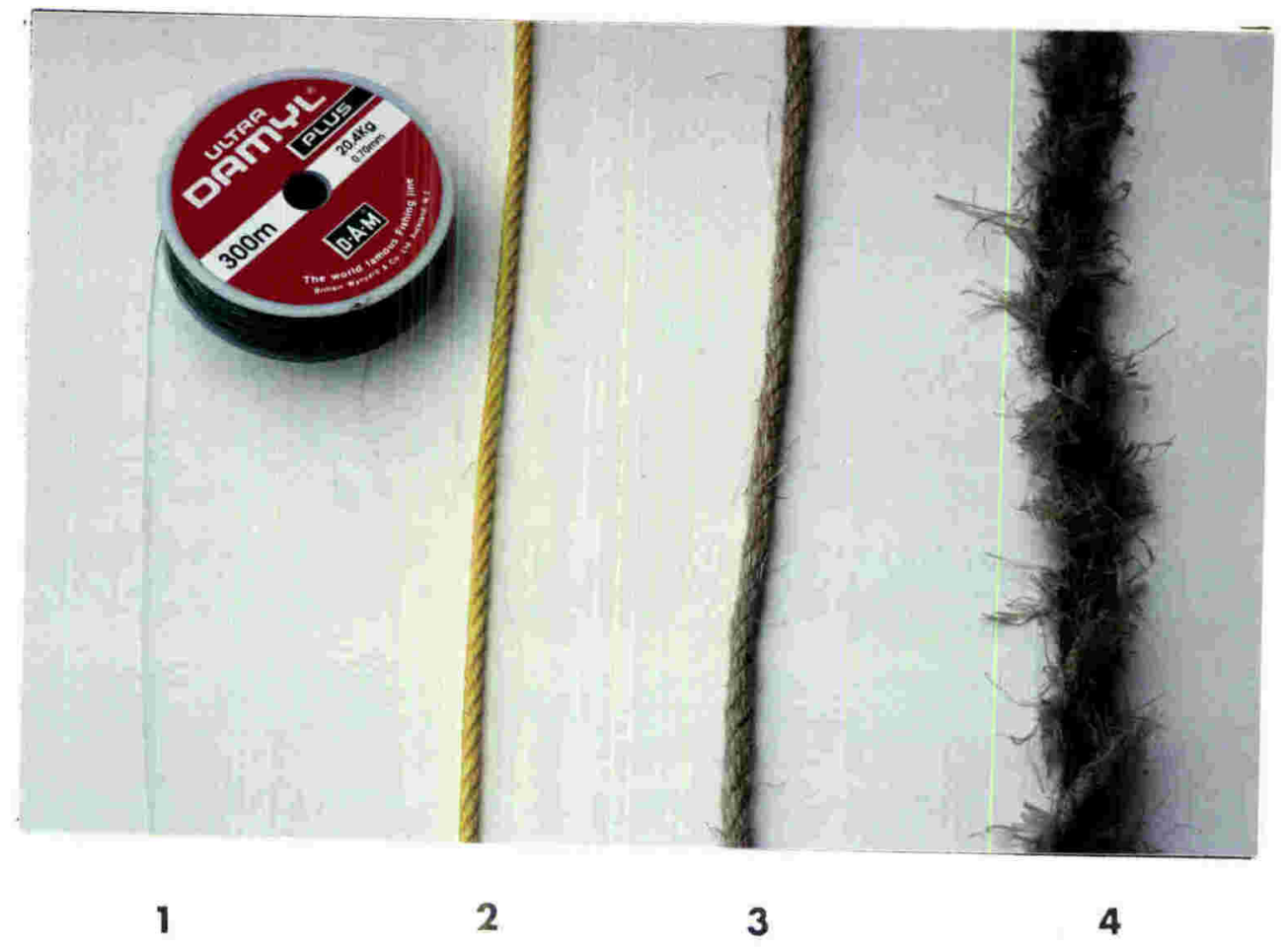

Plate 3.1.(Continued) c.ropes 1. nylon line 2. polypropylene rope 3. sisal rope 4 . Christmas-tree mussel rope 


\subsubsection{Spore seeding method.}

The Gracilaria spore seeding method, as developed in Malaysia and Thailand, requires a nursery tank for seeding the spores and for germling growth. The tank can be a discarded bathtub or other container large enough that the water temperature does not vary widely during the period of seeding. The substrates (nets or lines) are wound around seeding frames (Plate 3.2) and placed on the bottom of the tank. The seeding frames may be made of wood, non-metal pipe, bamboo or reasonably straight tree branches. A net to hold fertile "seed stock" plants is then suspended horizontally on top of the nursery tank and the tank is filled with seawater.

In the present study, seeding was conducted at the Victoria University Marine Laboratory at Island Bay, Wellington. The method used to seed spores onto a variety of substrate materials followed the above procedure, and the individual steps can be summarized as follows:

1) Use an outdoor fiber glass tank with $50 \mathrm{~cm}$ depth of seawater (salinity $32-35 \%$ ) as a nursery unit (Plate 3.2).

2) Place the seeding frames, with substrate materials wound around them (Plate 3.2), on the bottom of the nursery tank.

3) Place glass microscope slides on the bottom of uncovered petri dishes for monitoring the spore set and place on the bottom of the tank.

4) Place a nylon net over the top of the nursery tank and push down so the netting is about $10 \mathrm{~cm}$ below the surface and about $30 \mathrm{~cm}$ above the seeding frames.

5) Collect Gracilaria seedstock (tetrasporophytes and carposporophytes) from the wild population at Pauatahanui Inlet, and transport to the VUW Marine Laboratory as quickly as possible, keeping the weed cool and damp under wet cloth or newspaper in plastic bags or buckets, and avoiding lengthy crowding of the weed, to maintain its ability to release viable spores.

6) Clean the seedstock of epiphytes, rocks, shells, etc, then rinse in seawater.

7) Induce spore release by dipping the seedstock in a tank of seawater of salinity 25 
$\%$ o for $20 \mathrm{~min}$, or by spraying the seed stock with fresh water, and immediately place the weed back in full salinity seawater (35\%o).

8) Spread the seedstock out evenly on the top of the net, density approximately 500 $\mathrm{g}$ fresh weight per $\mathrm{m}^{2}$.

9) Leave the submerged seedstock undisturbed for 2 days at least. Do not aerate.

10) When the desired spore density has been reached (spore density on the slides 10 cells per microscope field at $100 \mathrm{X}$ magnification), remove the seedstock.

11) Leave the seeded substrate in the nursery tank at least 3 - 5 days before outplanting. 


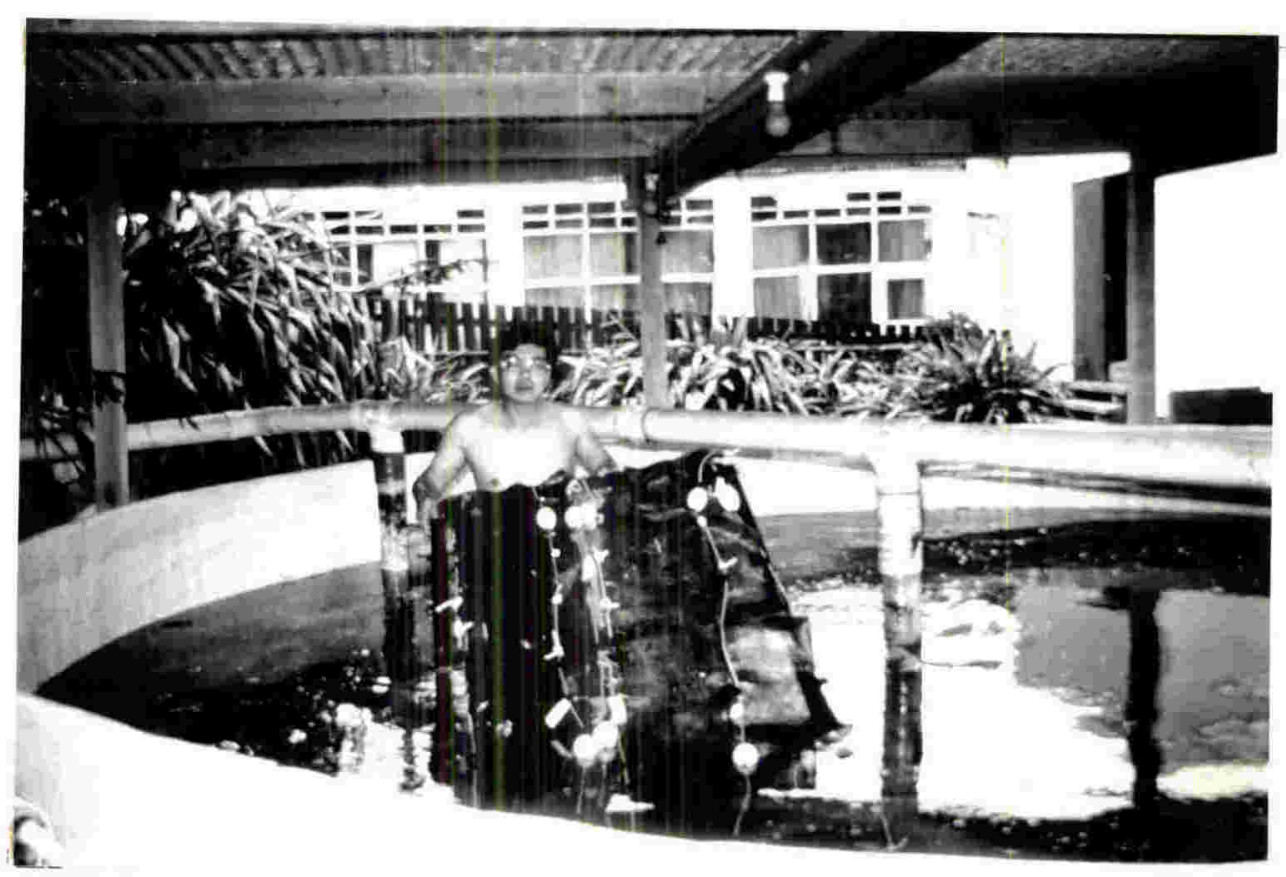

a

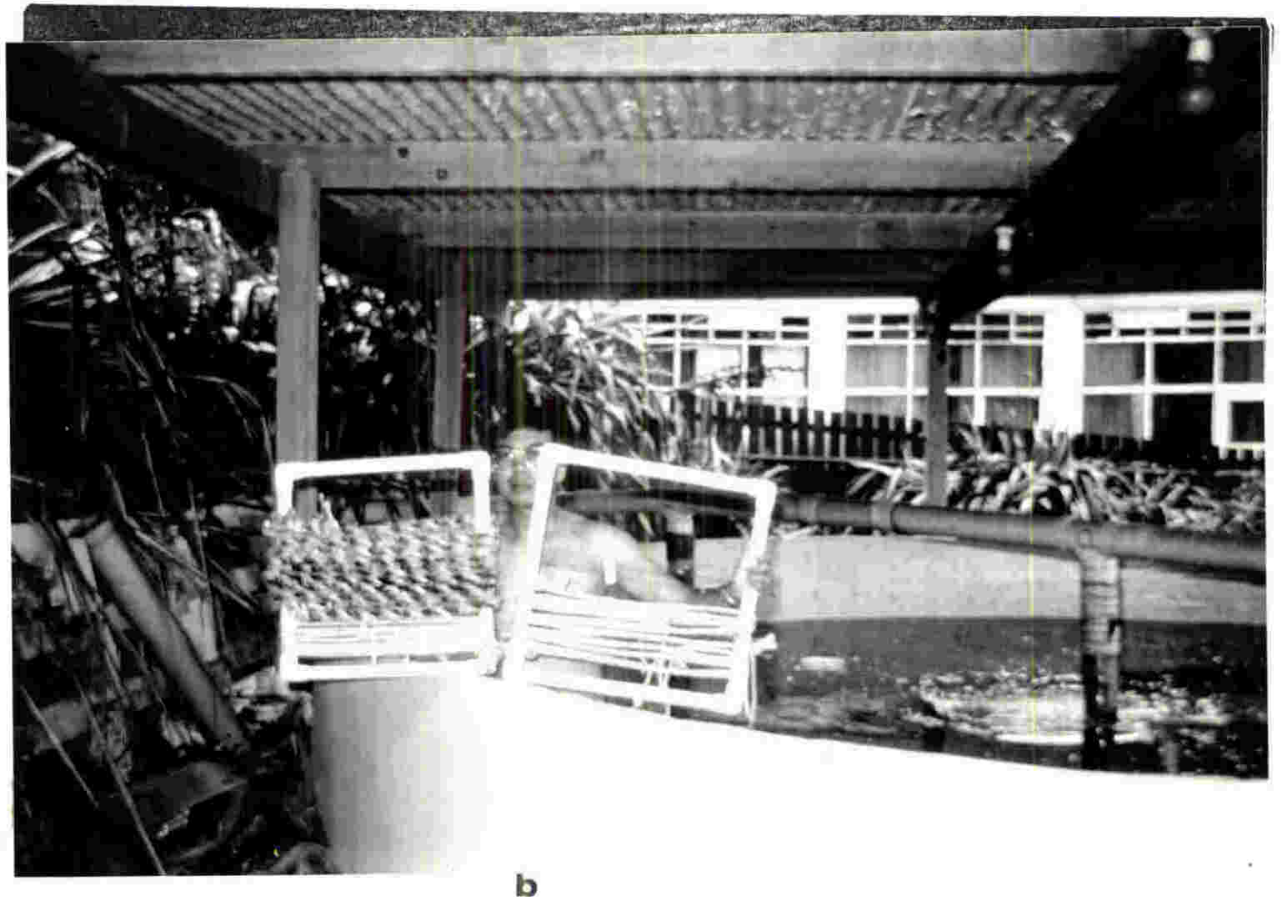

Plate 3.2. Nursery tank and seeding frames at Victoria University Marine Laboratory, Island Bay, Wellington. a. Net seeding (wrapped around $1 \times 3 \mathrm{~m}$ wooden frame) b. Seeding frames made from Eslon pipe ready for line seeding 


\subsubsection{Monitoring the spore set.}

The microscope slides in the nursery tank are essential to determine if the spores have been discharged and if they are viable. The slide is examined with an inverted microscope while still inside the petri dish. If the spores are not attached they will appear to roll back and forth on the surface when the slide is moved (gently!). If they appear attached the slide is removed and examined with a compound microscope. At $400 \mathrm{X}$ magnification, cell division will be visible. After initial inspection, the slide should be subjected to high water motion to determine the degree of spore adhesion. This is done by rinsing the slide under running seawater (or tap water if slide is immediately placed back into seawater) and re-examining the spores. If they are still attached, the substrate should be kept in the nursery tank for 3 - 5 days before being removed from the tank and outplanted. The outplanting method and farm layout will be described fully in section 3.2.5.

Types of treatment that may cause failure in spore seeding include heating, drying, rough handling, and delay in transporting the fertile Gracilaria to the nursery place.

\subsubsection{Outplanting.}

The seeded materials were kept in the nursery tank for 3-5 days to let the sporelings become established and firmly attached. Meanwhile, at the farm site at Duck Creek, the stakes, perimeter lines and floats to hold the seeded lines and nets were set in place (Figure 3.2).

When ready for planting the seeded lines, still wrapped around the frames, were each placed in a large plastic bag while still very wet (to prevent drying) and taken into the field. The seeded nets were coiled and treated the same way as the seeded lines. To put the lines and nets in place, the frames and coiled nets were removed from the bags and each end of the lines and nets tied to the perimeter line of the farm. In setting up the farm several precautions were observed. The lines and nets were tied tight enough to keep them taut, and so prevent them from rubbing on the bottom or becoming buried in the bottom sediments. The lines and nets were set parallel to the tidal currents to provide free and more uniform 
access to water exchange, to impose less strain on the lines and nets, to reduce the collection of flotsam and to reduce lateral entanglement of the lines and nets. The farm layout and installation are illustrated in Figure 3.2. and Plate 3.3.

Before outplanting, each seeded line and net was weighed in a drip-dry state with a top loading balance and the weight recorded as the "initial weight". 

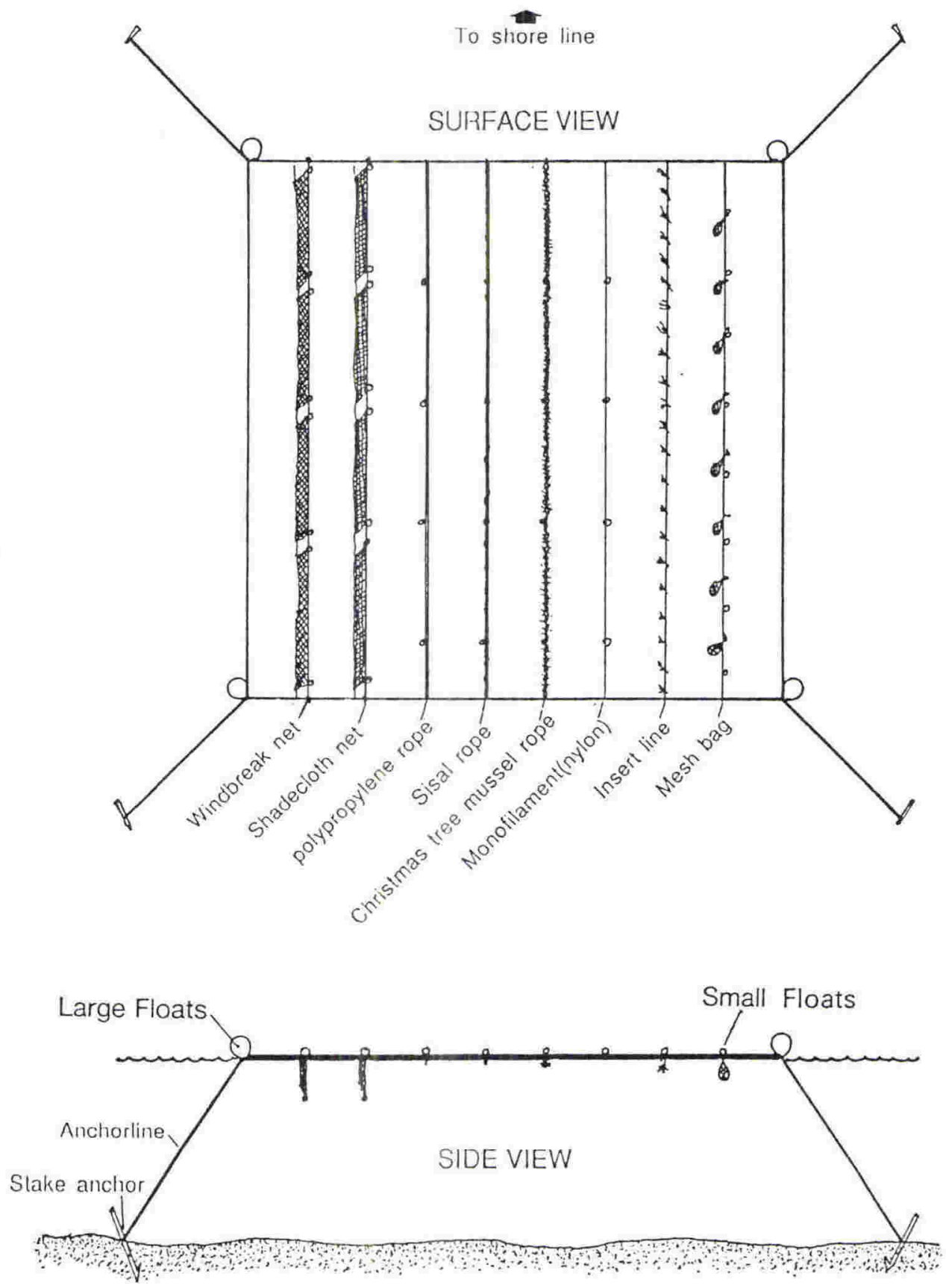

Figure 3.2. Diagram showing farm layout at Duck Creek, Pauatahanui Inlet, Wellington (simplified and not to scale). 

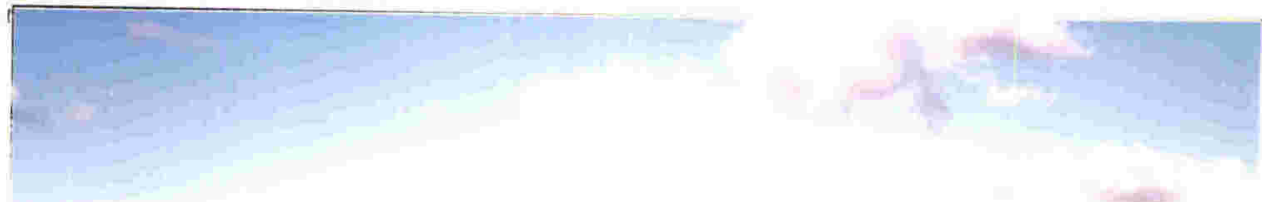

tanes
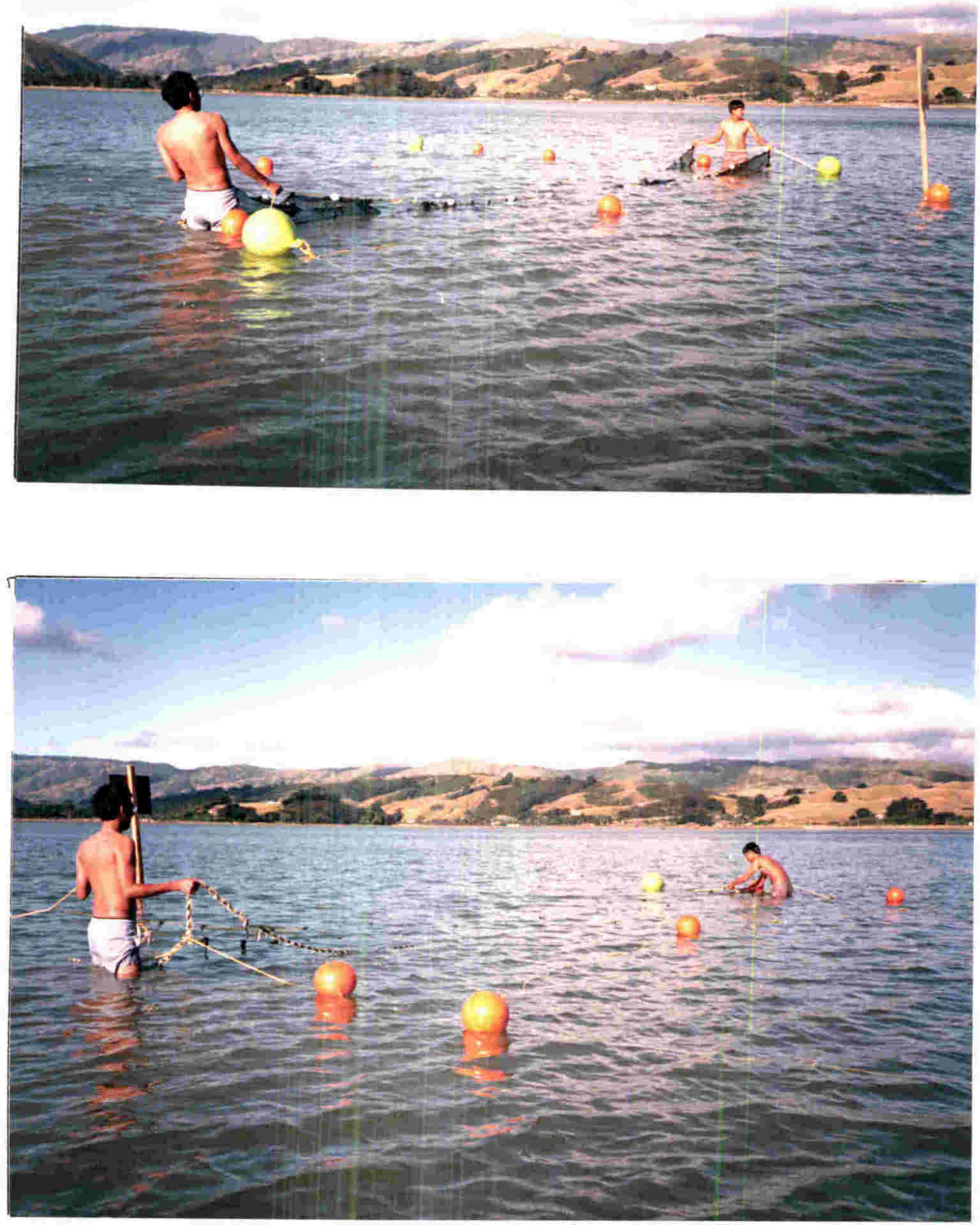

Plate 3.3. Farm installation at Duck Creek, Pauatahanui Inlet, Wellington. 


\subsubsection{Insert-line and mesh-bag method.}

In order to get information about growth rate more quickly than could be obtained from spore-grown thalli, insert-line and mesh-bag plantings were included.

Insert-lines were prepared by inserting individual branches of $G$. sordida between the strands of $6 \mathrm{~mm}$ polypropylene rope at $10 \mathrm{~cm}$ intervals. A double-insert method (Plate 3.7.c) was used to prevent the plant from moving back and forth in the water and becoming fatigued at the point where the thalli emerged from the rope.

Mesh-bags were prepared by putting Gracilaria thalli in plastic-mesh fruit sacks $30 \mathrm{~cm}$ in length, with $1 \mathrm{~cm}$ mesh (stretched length). About $50 \mathrm{~g}$ wet weight of the loose thalli were placed into the bags, the ends tied, and the bag labelled and tied to $6 \mathrm{~mm}$ polypropyline line and then tied to the perimeter lines of the farm (Plate 3.7).

\subsubsection{Environmental monitoring.}

The following environmental information was collected on a 2-weekly basis: seawater salinity, temperature, $\mathrm{pH}$, light intensity and nitrogen levels (as ammonia and nitrate).

Salinity was determined with an optical refractometer (Atago); temperature was measured at the water surface with a thermometer; $\mathrm{pH}$ was measured with an Orion Research Model SA $720 \mathrm{pH}$ meter; light intensity was measured at the surface and at the same depth as the substrates (1 foot subsurface) with a flat disc underwater quantum sensor (LI 190) connected to a LI-COR quantum meter (LI 188B); nitrogen levels were assessed by measuring ammonia concentration with an Orion Research Ammonia electrode (95-10), and nitrate levels, after reduction to nitrite, using an Orion Nitrogen oxide electrode (95-46) connected to an Orion Research meter Model SA 720 (see details of analytical procedures in Appendix 3).

\subsubsection{Growth rate and production analysis.}

Growth was monitored fortnightly as wet fresh weight increase $(\%)$ and the relative 
growth rate so obtained was expressed as the mean daily relative growth rate using the following formula (Hunt, 1978):

$$
\overline{\operatorname{RGR}}\left(\% \mathrm{~d}^{-1}\right)=\frac{\left(\log \mathrm{W}_{2}-\log \mathrm{W}_{1}\right)}{\mathrm{T}} \times 100
$$

where $W_{1}=$ the initial weight; $W_{2}=$ the final weight

$\mathrm{T}=$ time in days

Each mean monthly relative growth rate was the mean value for all determinations of relative growth rate on that substrate that came within each calendar month and was plotted on the graphs.

The total biomass production of the pilot farm was estimated for the year by adding up the amount of seaweed harvested from the farm. The farm was completely harvested and dismantled at the completion of the study (January 1990).

\subsubsection{Statistical analysis.}

Data of mean monthly relative growth rate of $G$. sordida on each type of substrate were compared using pairwise t-tests (Fuller, 1976), and differences were considered significant if the probability (p) $>Z<0.05$ (see Appendix 4).

\subsection{RESULTS.}

\subsubsection{Environmental studies.}

The environmental data obtained at Duck Creek are presented in Figure 3.3. 

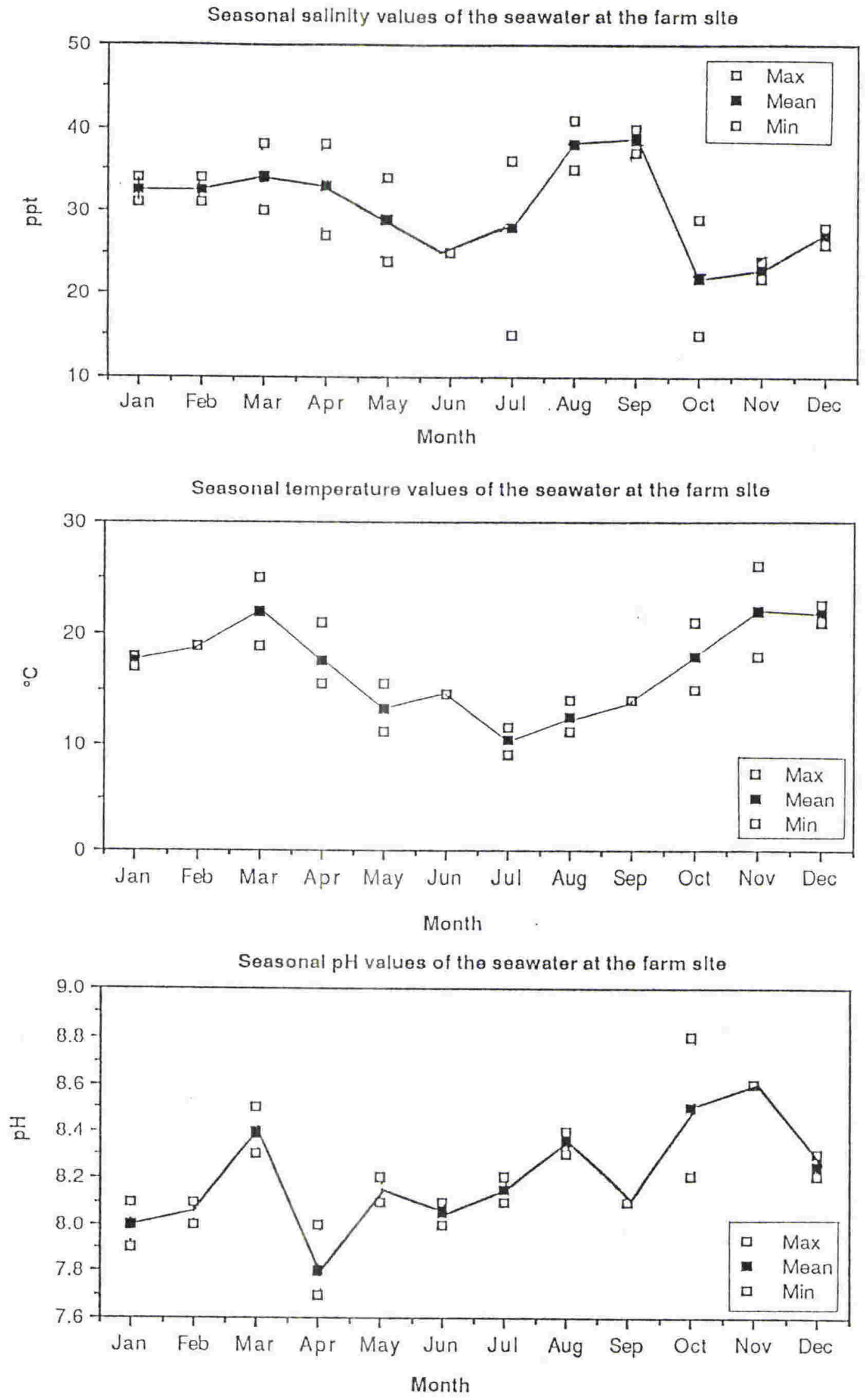

Figure 3.3. Seasonal values of the salinity, temperature. pH, light intensity and nitrogen levels of the seawater at the farm site, Duck Creek, Pauatahanui Inlet. 
Seasonal surface light Intenslty of the seawater
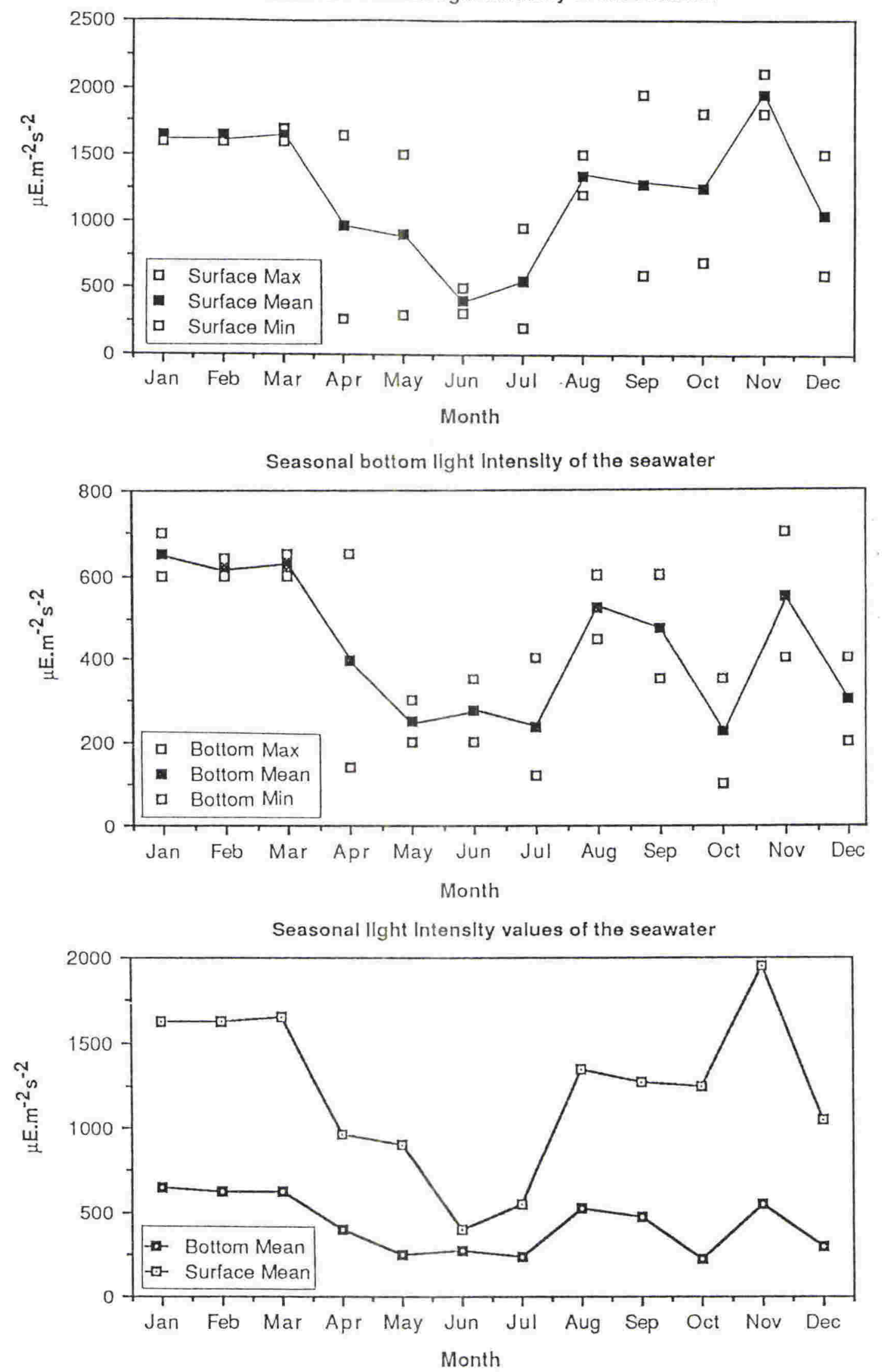

Figure 3.3. Continued. 


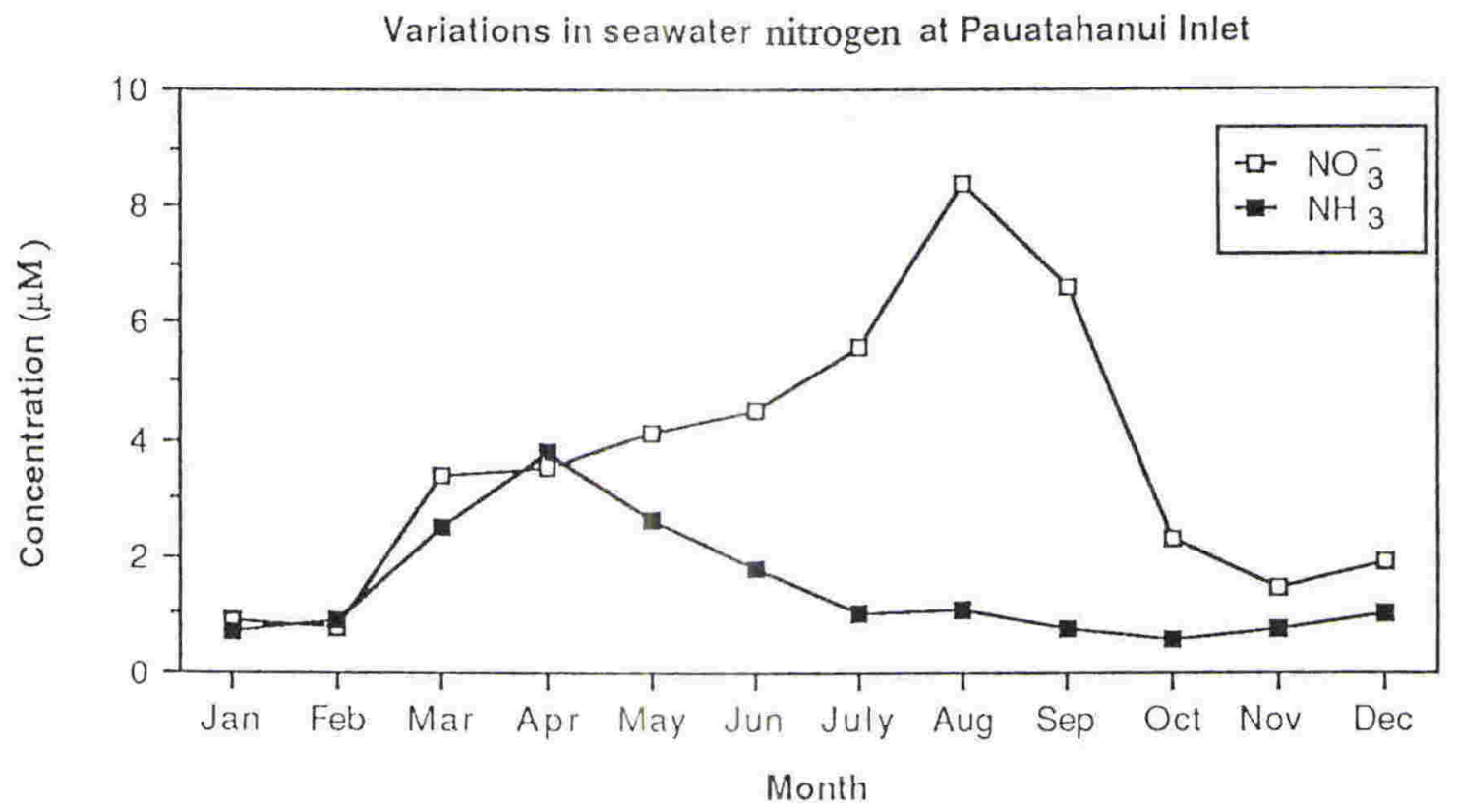

Figure 3.3. Continued. 
The highest salinity recorded was $38.5 \%$ in September, and the lowest was $22 \%$ in October. The water temperature ranged from $10^{\circ} \mathrm{C}$ to $22^{\circ} \mathrm{C}$. The highest water temperature was found in November and the lowest was in July. The pH value ranged from 7.8 to 8.6. The highest $\mathrm{pH}$ value was in November and the lowest was in April. The subsurface light intensity ranged from 225 to $650 \mathrm{\mu E} \cdot \mathrm{m}^{-2} \cdot \mathrm{s}^{-1}$. The light intensity at the surface fluctuated between $350 \mu \mathrm{E} \cdot \mathrm{m}^{-2} \cdot \mathrm{s}^{-1}$ (July) and $1950 \mu \mathrm{EE} \cdot \mathrm{m}^{-2} \cdot \mathrm{s}^{-1}$ (November). The nitrate concentration in the seawater at the farm site ranged from 0.8 to $8.4 \mathrm{uM}$, the highest value was recorded in August and the lowest value was in February. The ammonia concentration ranged from 0.6 to $3.8 \mu \mathrm{M}$. The highest value was found in April and the lowest was found in October.

\subsubsection{Growth rate.}

The mean relative growth rates (\% $\mathrm{d}^{-1}$ ) of $G$. sordida cultured by seeding spores onto different substrates are presented in Table 3.1. and Figure 3.4. 


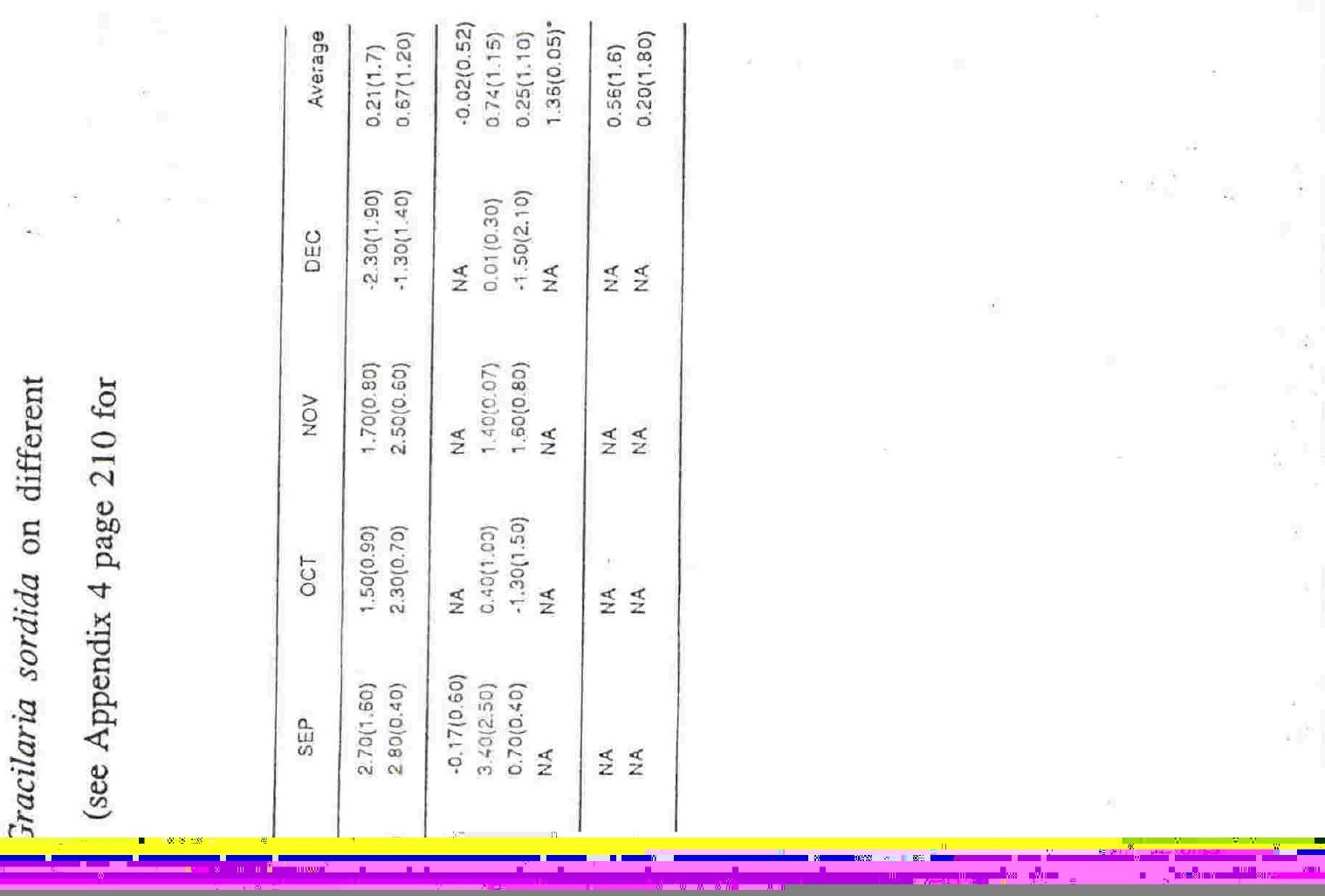


Seasonal growth rate of Gracllarla sordida In net culture

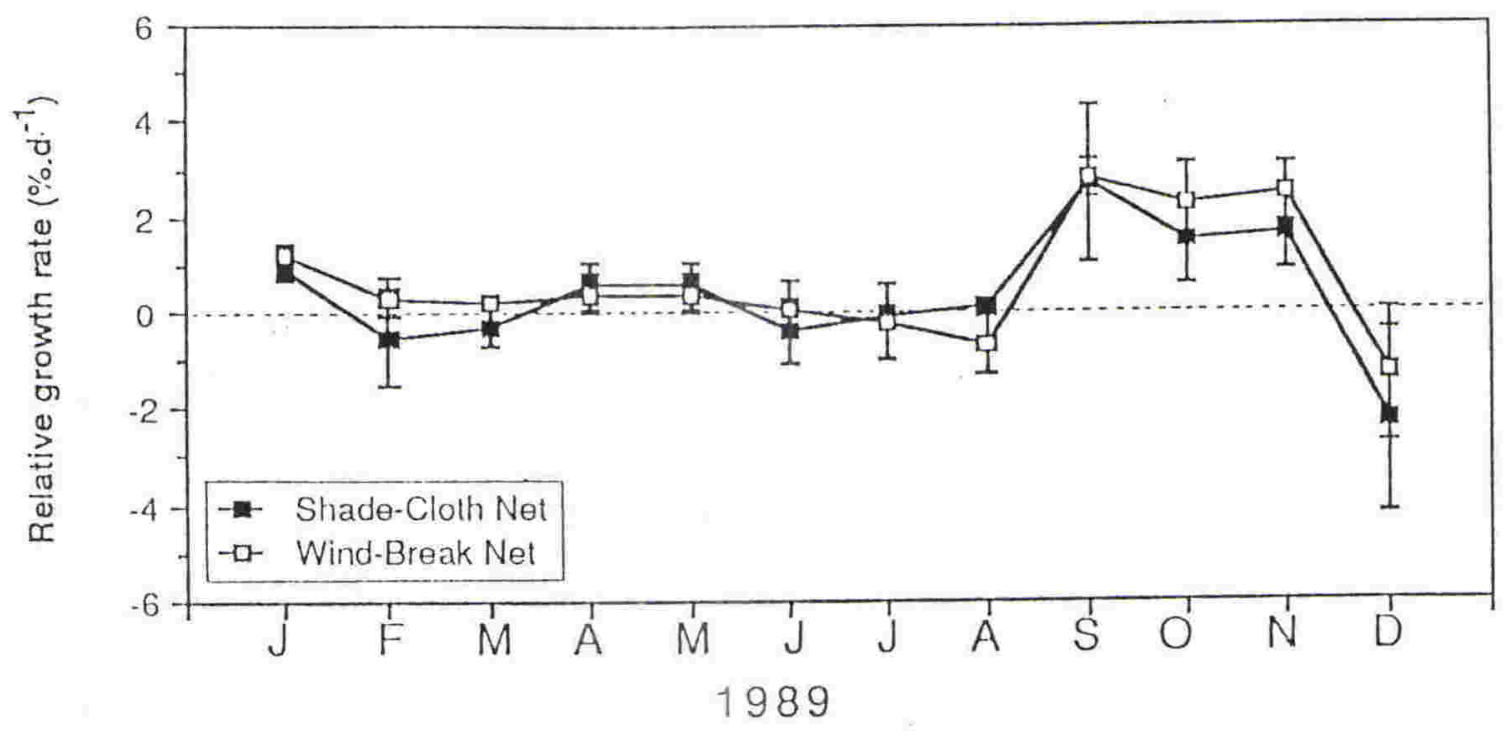

Seasonal growth rate of Gracilaria sordida In rope culture

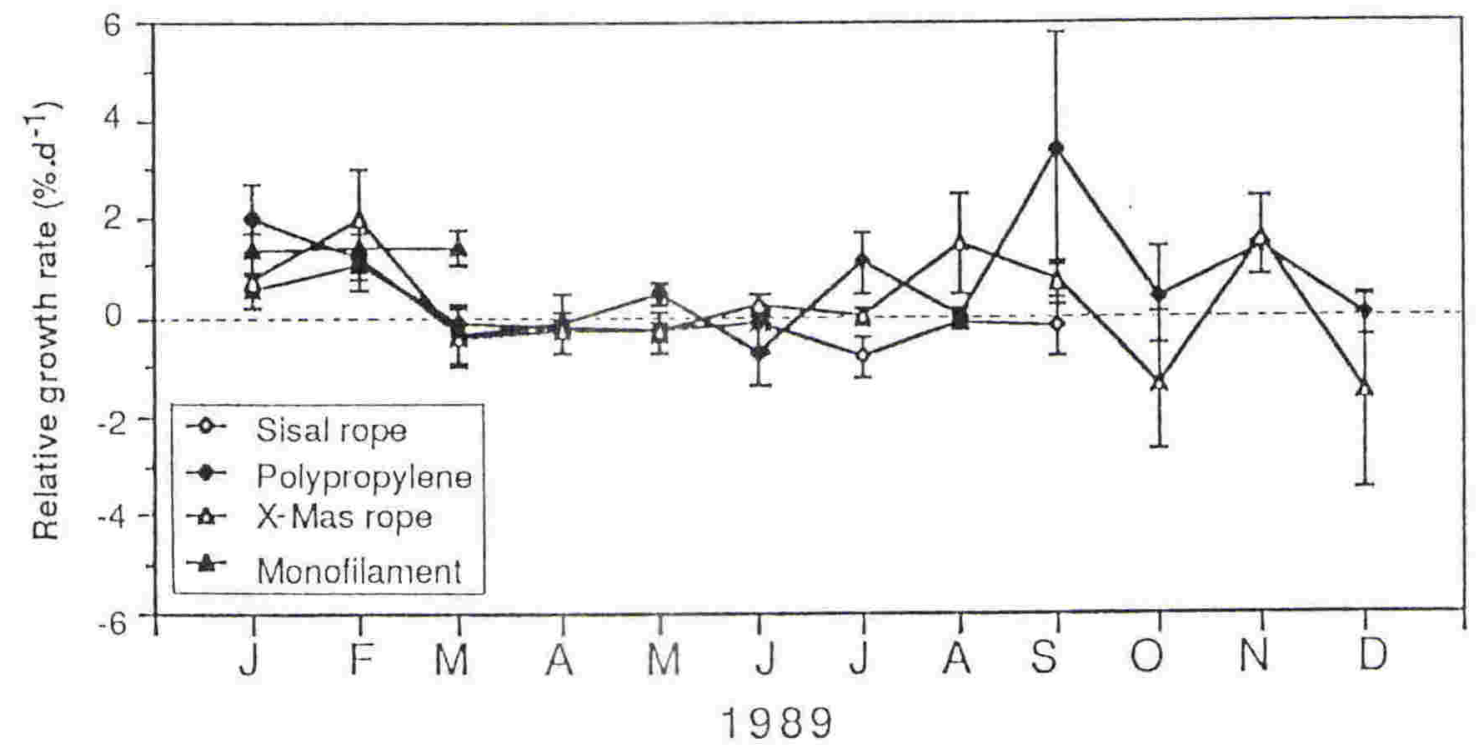

Figure 3.4. The mean relative growth rates (\% ..$\left.^{1}\right)$ of Gracilaria sordida on different artificial substrates. vertical bars represent $95 \%$ confidence limits (mean $\pm 2 \times \mathrm{SD}$ ). 
Seasonal growth rate of Gracilaria sordida In insert line and mesh bag culture

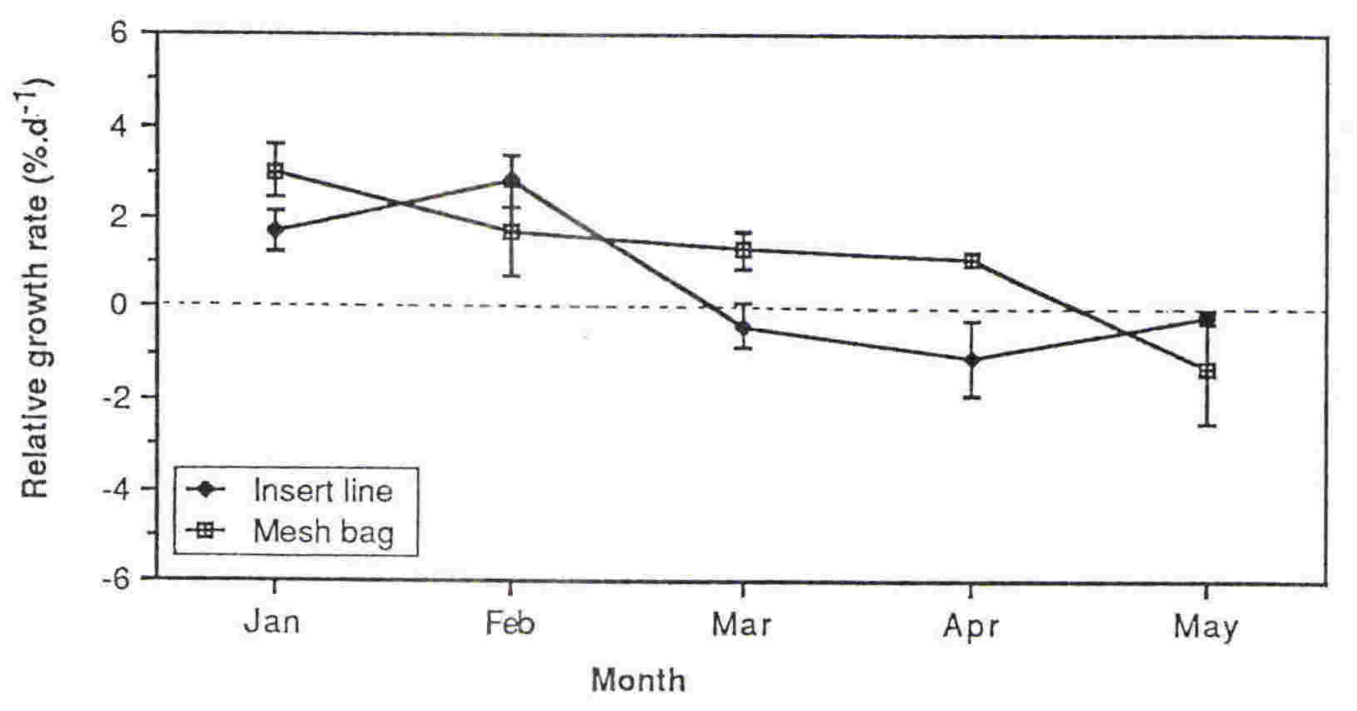

Figure 3.4. (Continued).

\subsubsection{Growth rate on spore-seeded nets.}

The fastest relative growth rates obtained with wind-break and shade-cloth nets as substrate were similar $\left(2.8 \% \cdot \mathrm{d}^{-1}\right.$ and $2.7 \% . \mathrm{d}^{-1}$ respectively), and were found in spring (September) (Figure 3.4 and Plate 3.4). 

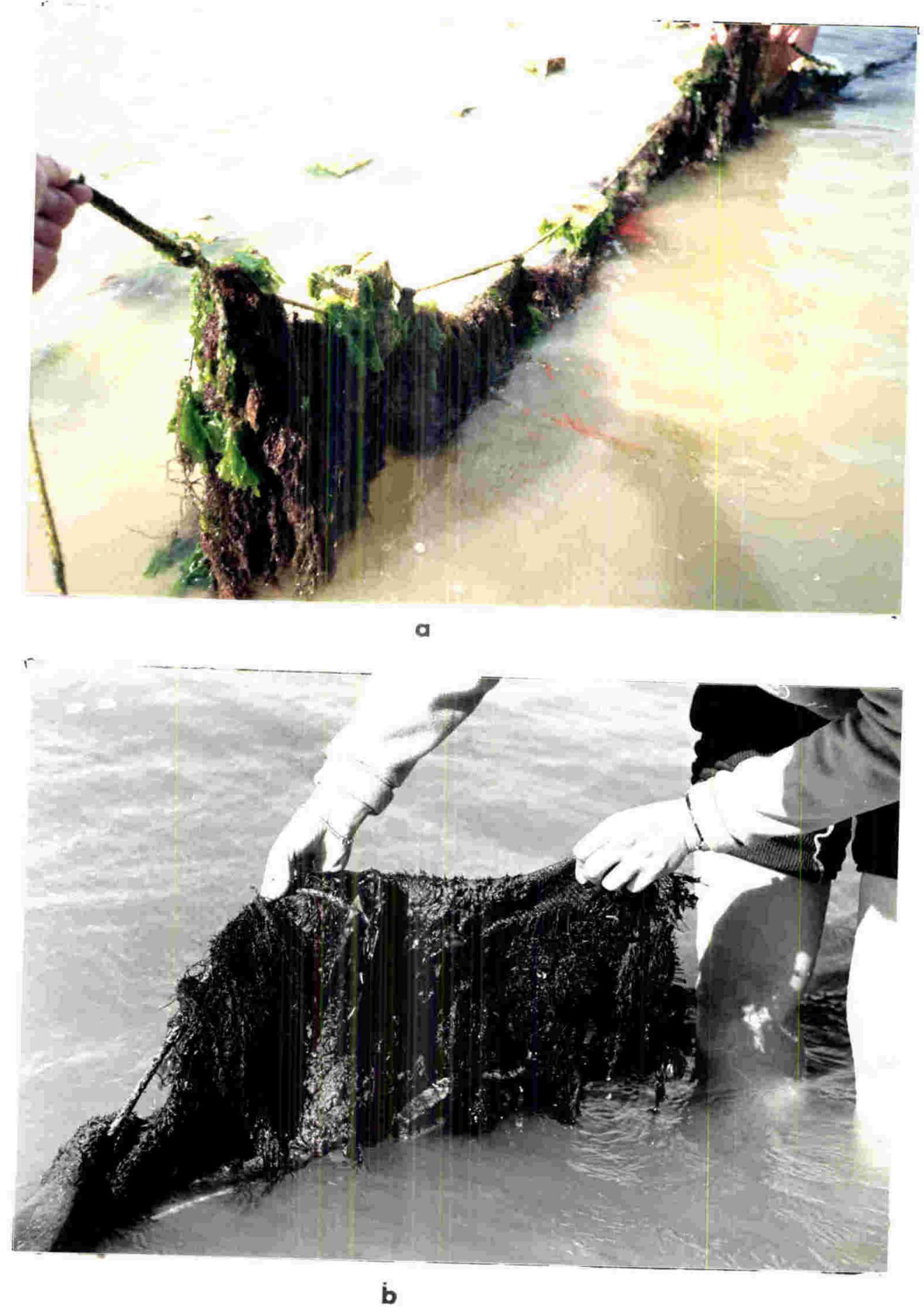

Plate 3.4. Gracilaria sordida on nets seeded with spores, after 6 months of growth. a. wind-break net b. shade-cloth net 


\subsubsection{Growth rate on spore-seeded long lines.}

Sisal rope was the cheapest substrate tried in this experiment but it was found to be susceptible to decay in seawater as it became weak and broke after 9 months of use. The relative growth rate of $G$. sordida on sisal rope was also very poor because the rope surface had a film of greasy material, perhaps from the process of manufacture, that prevented the attachment of spores.

All the synthetic ropes, namely polypropylene, Christmas-tree mussel and nylon were not only satisfactory substrates for spore attachment, but were also found to be resistant to decay in seawater. Polypropylene rope was in particular appropriate both for attachment of vegetative fragments (insert method) and as a substrate for spore settlement (spore seeding method). The maximum relative growth rates of $G$. sordida in long-line culture were obtained in Spring.

The best growth rates were obtained using polypropylene rope. The maximum growth rate on polypropylene rope (Manline rope) was very impressive $\left(3.4 \% . \mathrm{d}^{-1}\right)$ (Figure 3.4 and Plate 3.5).

The maximum growth rate of $G$. sordida on Christmas tree mussel rope was $1.5 \% . \mathrm{d}^{-1}$ (Figure 3.4 and Plate 3.6).

The maximum growth rate on nylon monofilament line was $1.9 \% . \mathrm{d}^{-1}$. The nylon monofilament line was destroyed by theft after only 4 months of use (Jan-Apr). However, before the nylon monofilament lines disappeared, many of them contained small plants 1 $1.5 \mathrm{~cm}$ long and the maximum growth rate for the 4 month period was $1.9 \% \cdot \mathrm{d}^{-1}$.

\subsubsection{Insert-line and mesh-bag culture.}

The highest mean relative growth rates obtained from insert-lines and mesh-bags were the same $\left(2.8 \% \cdot \mathrm{d}^{-1}\right)$ (Table 3.1$)$. However, the average mean relative growth rate for the whole growth period is over twice as high for insert lines as it is for mesh bags. The 
difference between the average relative growth rates for these two treatments is due largely to differences in the rate of loss of material, as shown by the negative growth rates which set in about March, because of increase turbulence and theft. 
$\curvearrowright$ MADE N N

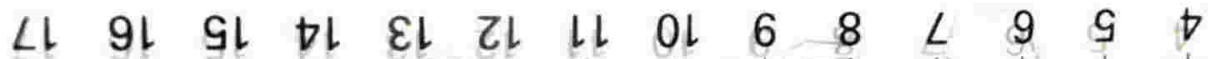

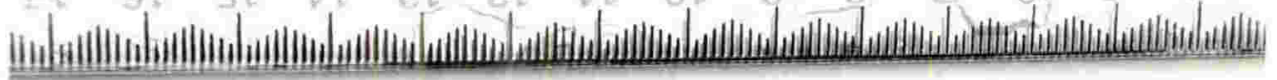

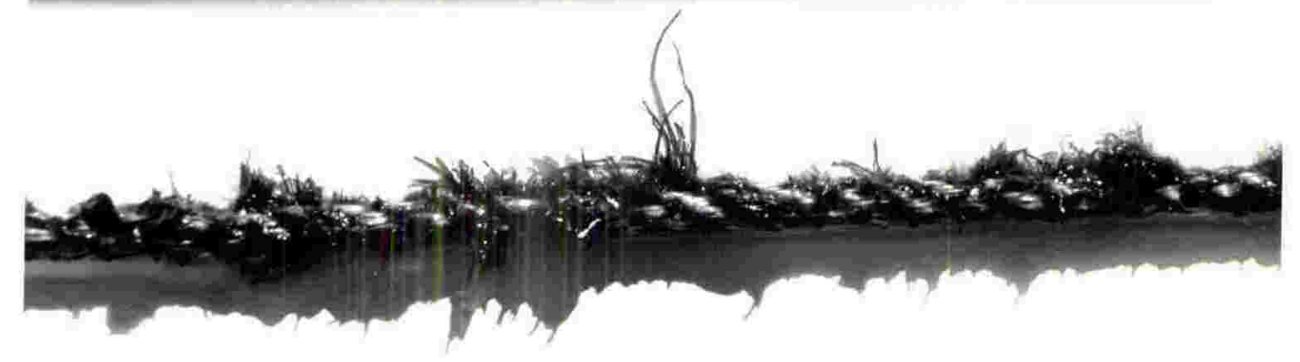

a

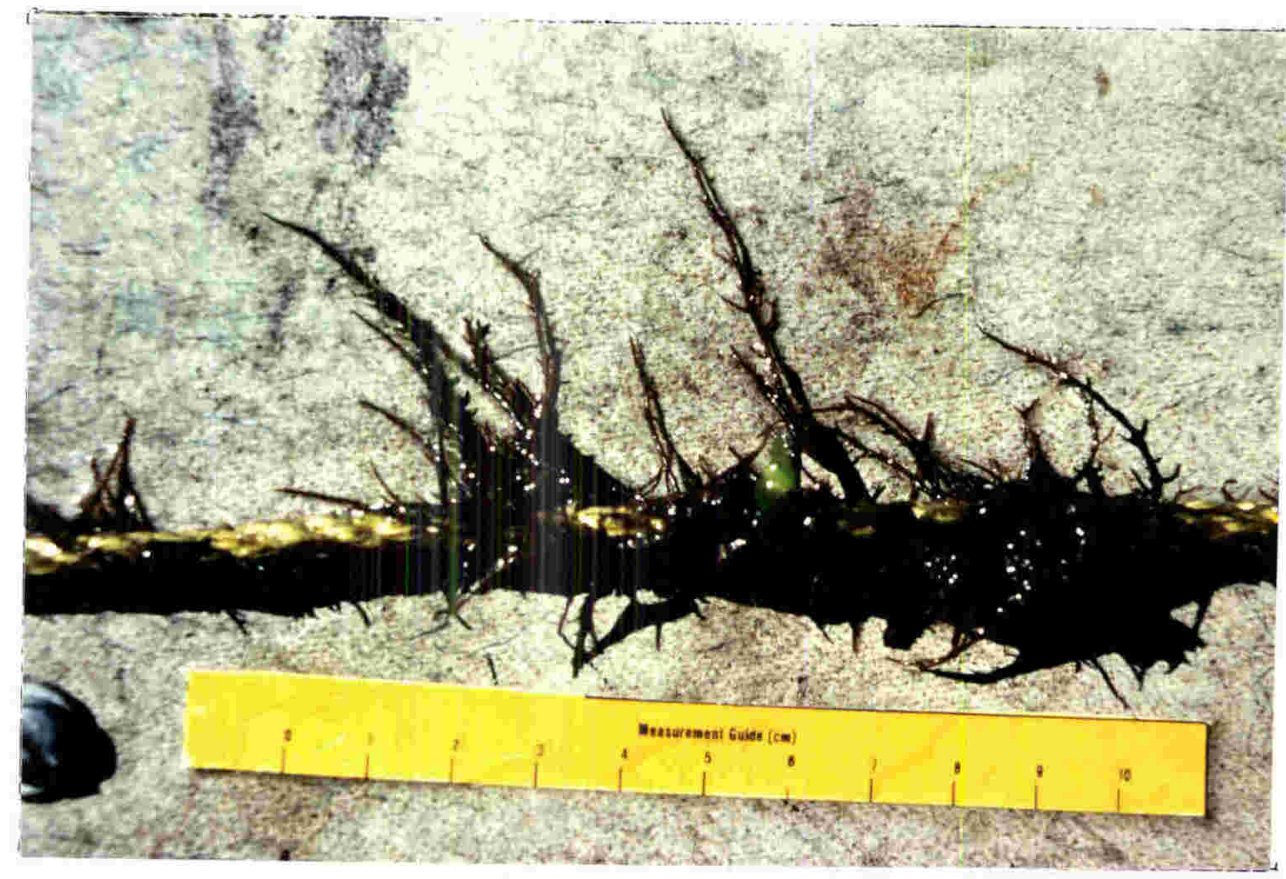

b

Plate 3.5. Growth of Gracilaria sordida on polypropylene rope seeded with spores.

a. after 2 months b. after 4 months c. after 6 months 


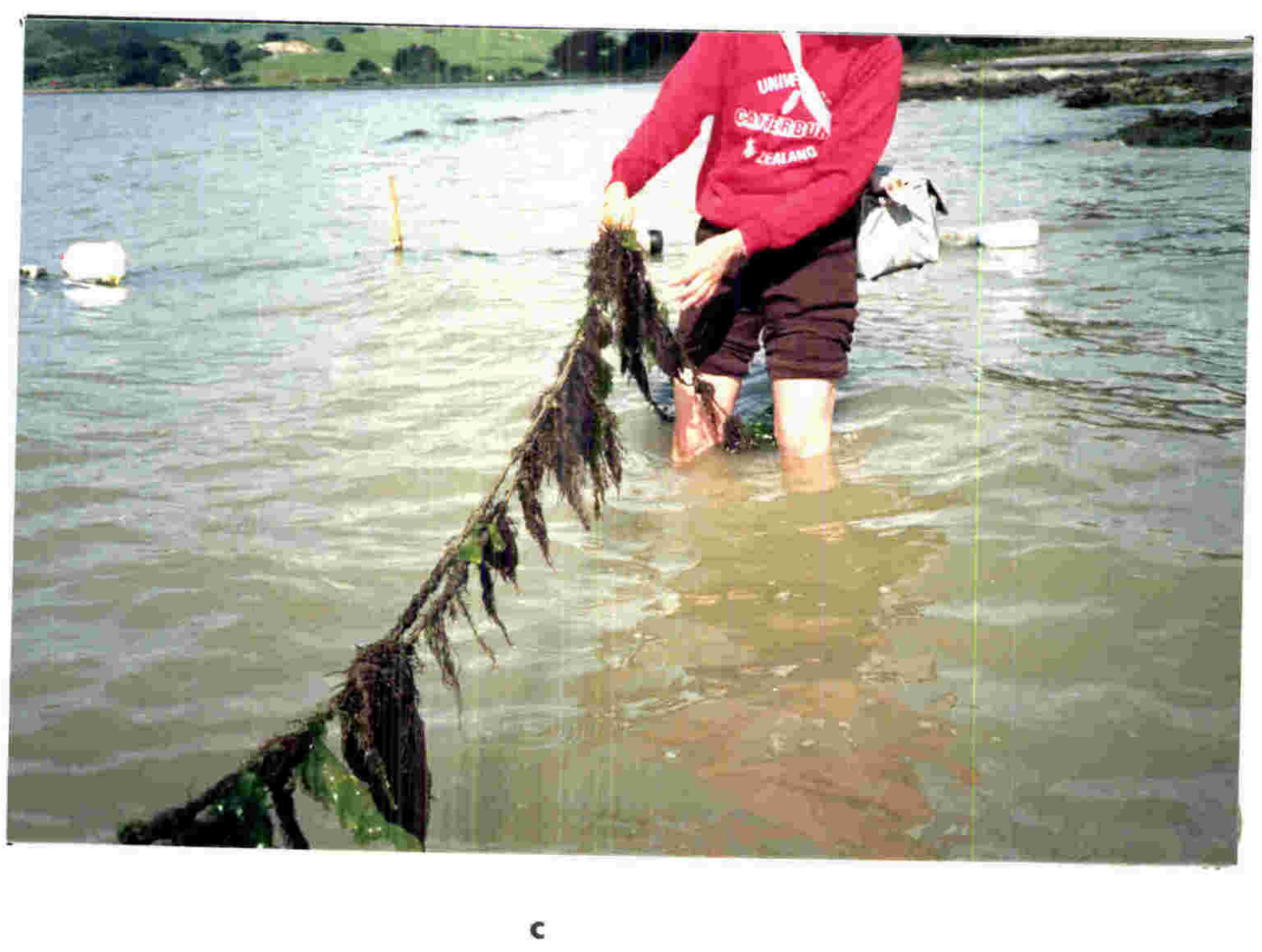

Plate 3.5. (Continued). 

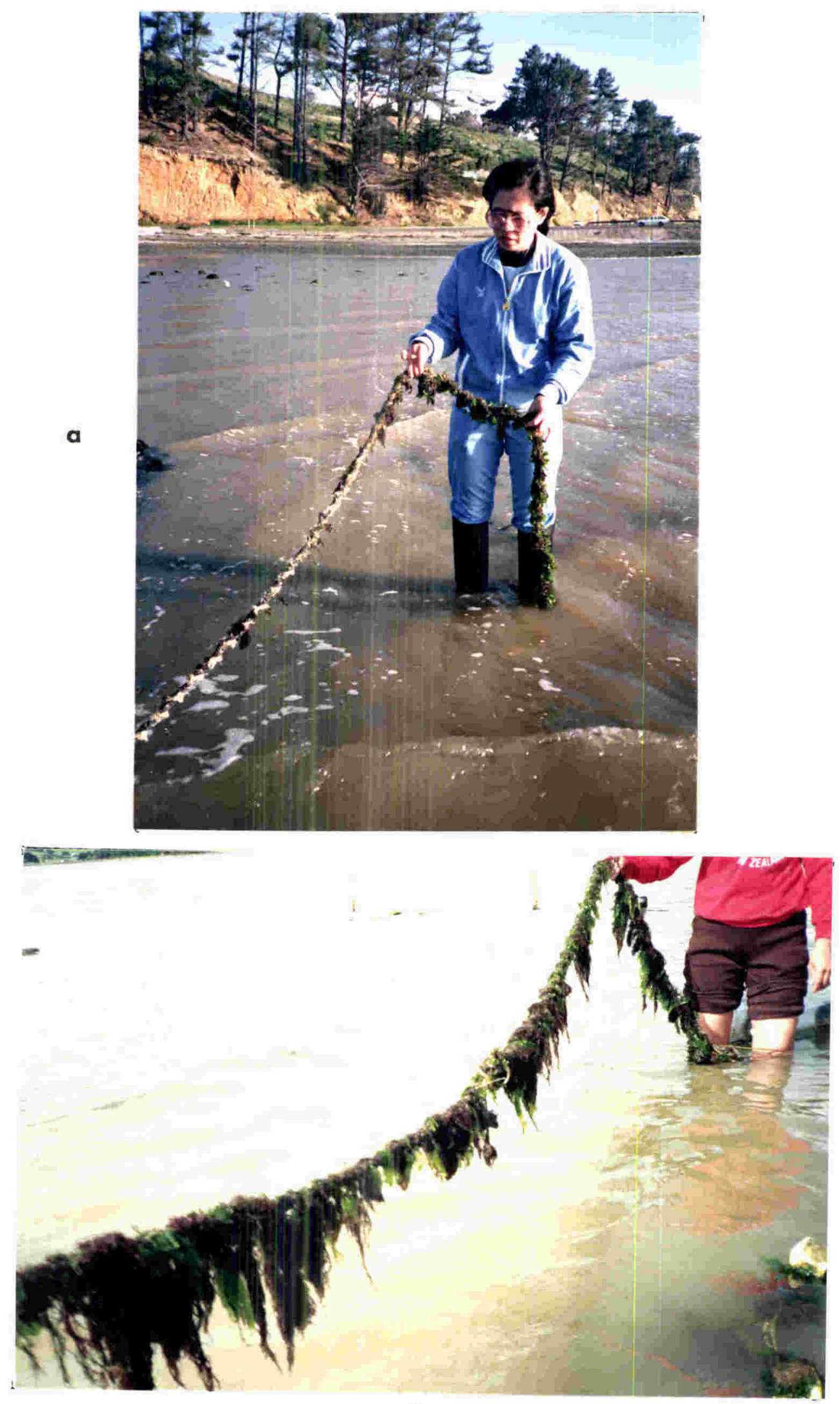

b

Plate 3.6. Growth of Gracilaria sordida on Christmas-tree mussel rope seeded with spores. a. after 1.5 months b. after 6 months 


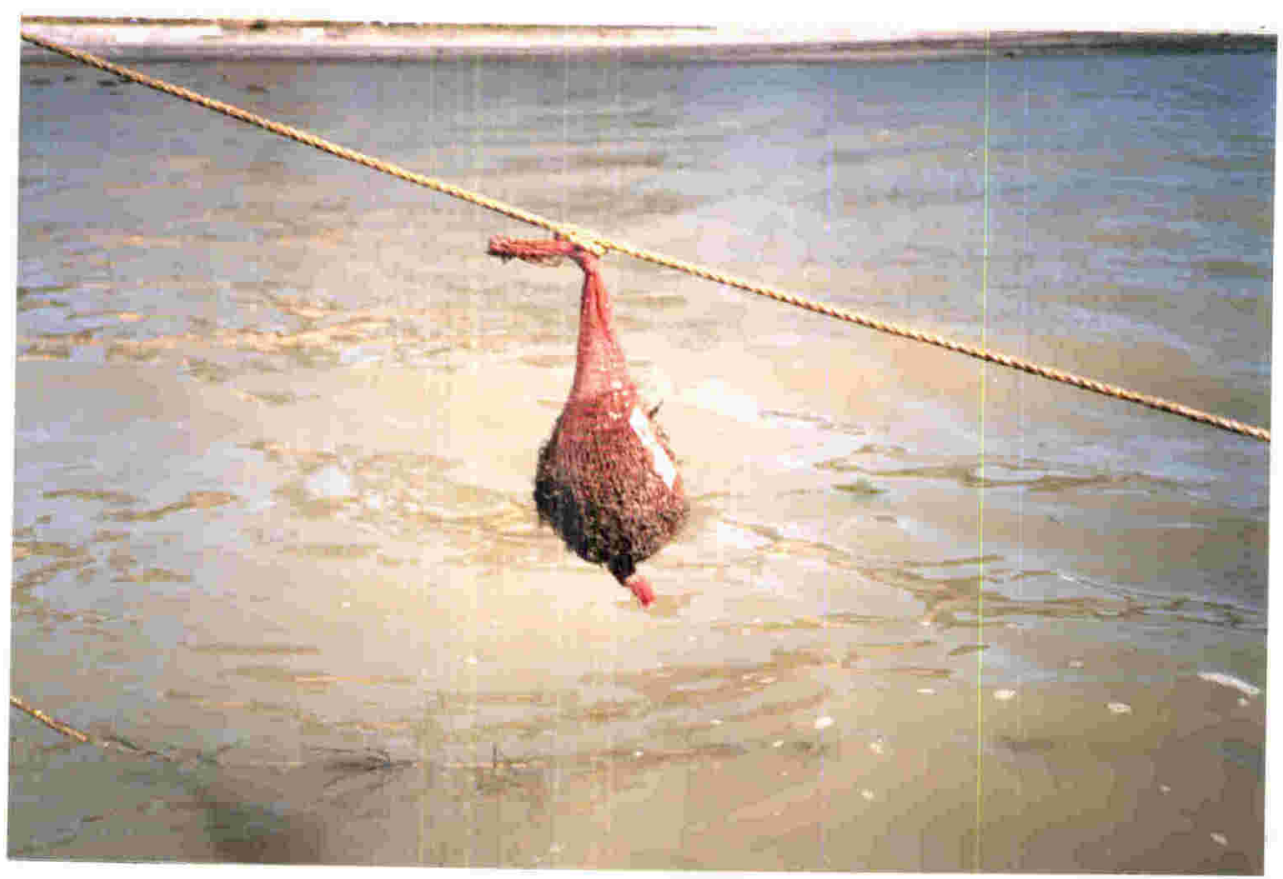

a

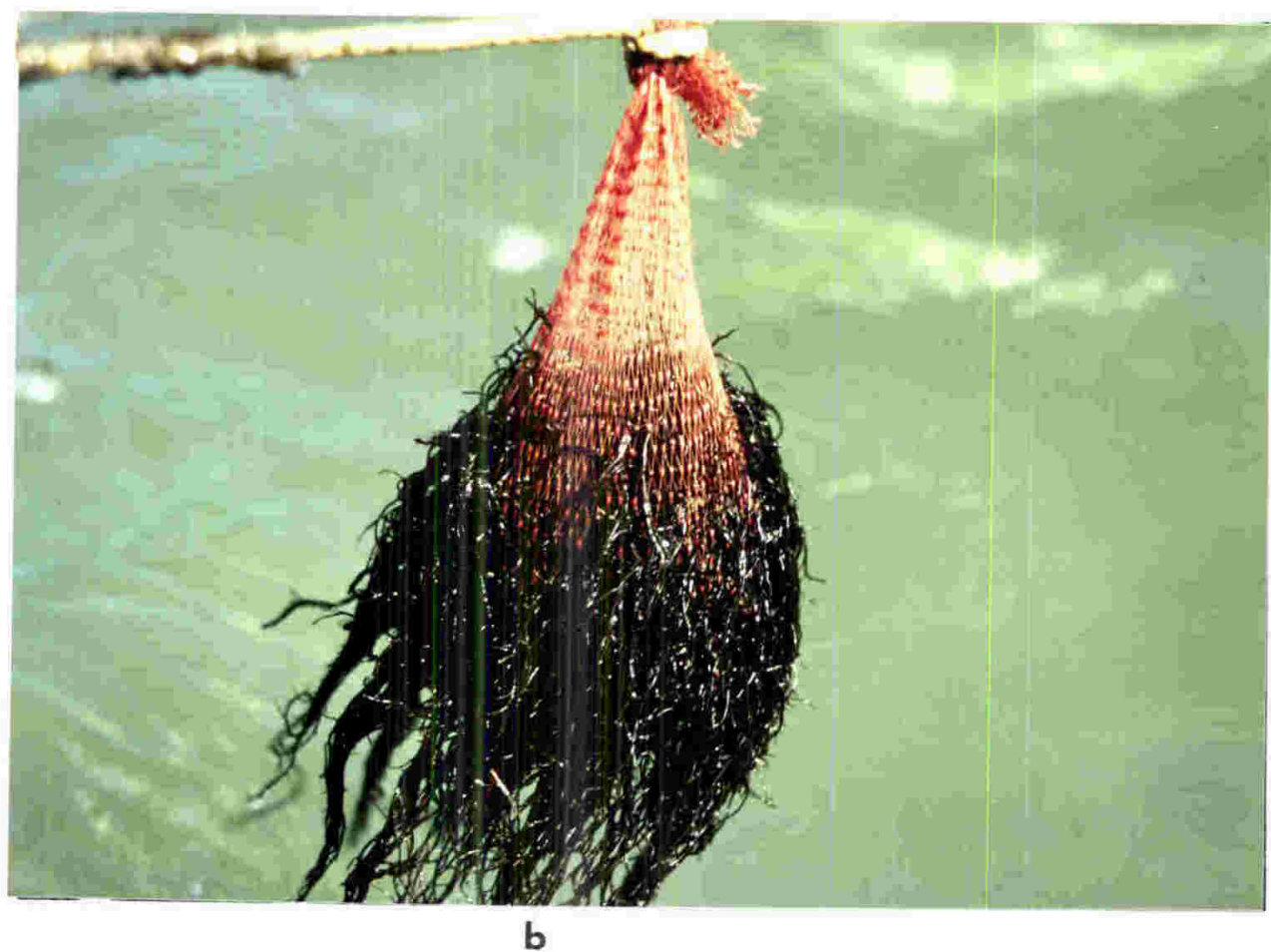

Plate 3.7. Growth of Gracilaria sordida from fronds, in mesh bags and on insert lines

a. at the beginning of experiment $b$. after 2 months

c. showing double insert method at the beginning of experiment 


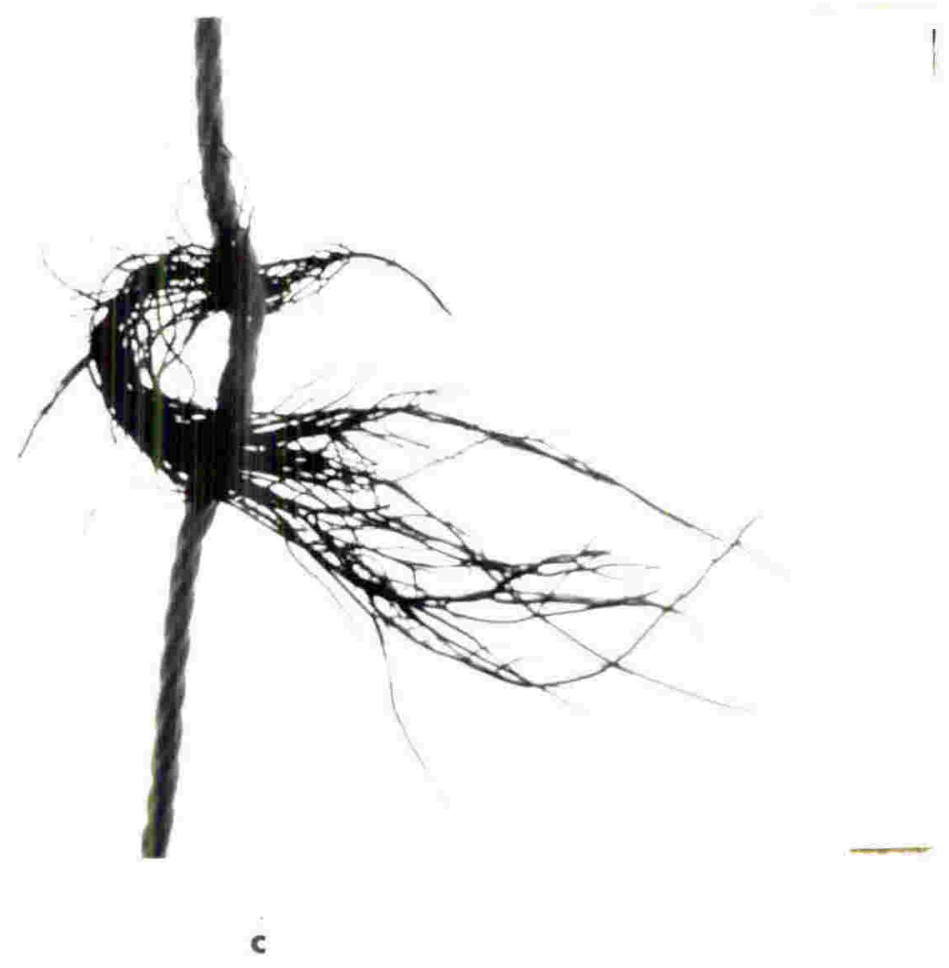

Plate 3.7. (Continued) 


\subsubsection{Total biomass production (annual yield).}

A total of $24.4 \mathrm{~kg}$ of seaweed was harvested from the pilot farm (19.3 $\mathrm{kg}$ from the net-culture and $5.1 \mathrm{~kg}$ from the line-culture), equivalent to an annual production of 182 tonnes $\mathrm{ha}^{-1} \cdot \mathrm{y}^{-1}$ (fw) (calculated by extrapolated an annual yield from pilot farm to 1 hectare). The dry weight of the thalli averaged approximately $10 \%$ of the wet weight; hence the production was equivalent to 18.2 tonnes of dry matter per hectare per year.

\subsubsection{Farming problems.}

The problems encountered in field culture included epiphytes, sedimentation, vandalism or theft and strong waves.

\subsubsection{Epiphytes.}

Epiphytic weeds such as diatoms, Ceramium, Enteromorpha, Polysiphonia and Ulva were a major problem in the experimental Gracilaria farm (Plate 3.8). The highest density of epiphytes was found in summer.

The only feasible means to eliminate the weeds was to remove them by hand, which not only involved a lot of labour but also tended to break the Gracilaria plants off the substrate.

\subsubsection{Sedimentation.}

Accumulation of sediments was also a major problem, necessitating cleaning mud from the substrates at least every two weeks. Moreover, some plants fell off the lines and nets each time they were cleaned. The hand-cleaning procedure is impractical as a farming technique.

It is very likely that the accumulation of epiphytes and sediments reduced the growth rate of the Gracilaria because they interfered with the available light both directly by shading and indirectly by causing sinking of the Gracilaria. 


\subsubsection{Vandalism or theft.}

In April and August all floats from the farm were stolen. Plants on ropes and nets appeared damaged by both abrasion on the bottom and by vandalism. Some culture lines were lost (nylon monofilament), and some plants on individual ropes were missing. Laminate bottles (2 1 milk bottles or soft drink bottles) and blocks of polystyrene foam were used to replace the pear shaped floats that were taken. The "bottle/foam" floats were cheap (free) and less likely to tempt thieves and vandals, although they looked untidy.

\subsubsection{Turbulent water.}

Turbulent water generated by gales or storms also had an adverse impact on the open water Gracilaria farm, causing some plants to be carried away by currents or waves. $G$. sordida from Pauatahanui Inlet is therefore too delicate to tolerate much turbulence. 

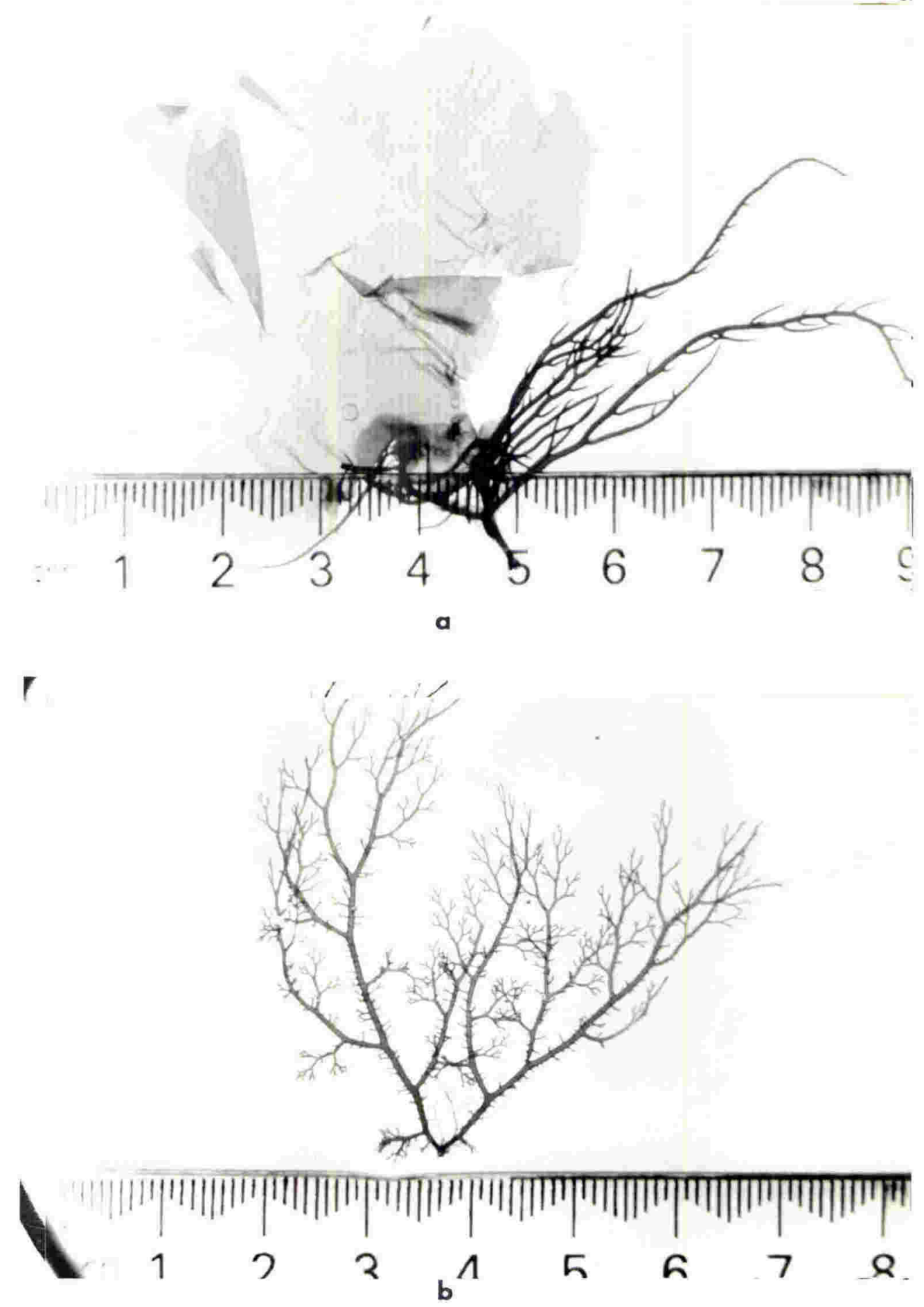

Plate 3.8. Epiphytes of Gracilaria sordida

a. Ulva(Chlorophyceae) b. Ceramium (Rhodophyceae) c. Polysiphonia (Rhodophyceae) 


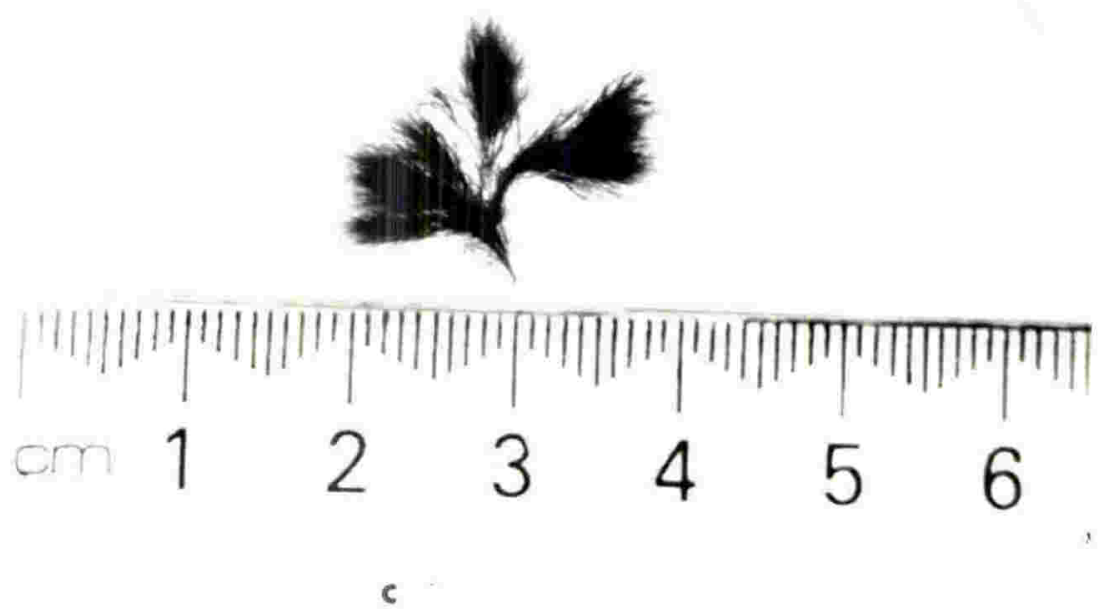

Plate 3.8. (Continued) 


\subsection{DISCUSSION.}

Water salinity, temperature and light intensity showed a seasonal trend, with a winter minimum and a spring and/or summer maximum, while nitrogen was low in summer and moderately high throughout the autumn and winter - with an August/September peak and the relative growth rate also showed a similar trend to these environmental factors.

The highest growth rate of $G$. sordida grown from spores was obtained from the plants on polypropylene rope $\left(3.4 \% \mathrm{~d}^{-1}\right)$. However, the growth rate obtained from the plants on nylon monofilament line had also shown a high trend. Unfortunately, the treatment was stopped by the theft of the lines so the data do not allow full comparisons to be made.

The maximum growth rate obtained using insert lines and mesh bags was $2.8 \% \mathrm{~d}^{-1}$ This value is lower than those of Pickering (1990) for G. sordida grown by these methods at Mokomoko Inlet, Invercargill. He reported that the mean growth rate, obtained during summer months when the growth rate was highest, ranged from $3.3 \%$. $\mathrm{d}^{-1}$ to $4.9 \% . \mathrm{d}^{-1}$ for insert lines, depending on the rope type, and was $4.2 \% \cdot \mathrm{d}^{-1}$ for mesh bags. Insert lines may be too labour intensive to make on a commercial scale. However, multiple harvests from the same rope may make it cost-effective. Harvesting Gracilaria from long line culture can also be simplified by pulling the line through a weed trimmer in a manner rather similar to the method used in Japan for harvesting Porphyra. The rope, with basal portions of the thalli still attached, can be placed back in the water for another period of growth. Generally the insert line is not treated as a farming method for Gracilaria but merely as a means of placing fertile material close to a farm substrate so that spores can settle, attach and grow on the latter, or as a means of investigating growth rate.

The mesh bags did not allow plants to grow as fast as expected, perhaps because the bags were packed fairly full. Self shading would thus have limited growth. Indeed the plants in the middle of the bag died, and only the outermost plants could grow (Figure 3.11). The mesh bag growth rate value obtained from this study is lower than those of Pickering (1990) for Pickering's mesh bags were horizontal not vertical and hence may have been 
better illuminated and had a greater surface area/volume.

The reasons that the growth rate obtained from nets was lower than that from polypropylene rope are probably firstly that the nets accumulated sediments more easily and secondly that the nets were "taller" in the water column, and hence a greater proportion of the weed would have been self shaded and at greater depth. The low or negative $\overline{R G R}$ in the winter months might result from both plants loss during storms and poor growth conditions.

Published growth rates for a number of species of Gracilaria cultivated under a variety of experimental conditions show considerable variation, a range from 1 - $47 \% . \mathrm{d}^{-1}$ having been reported (Table 3.2). In fact, it is difficult to compare the growth rate of G. sordida with other Gracilaria species because different formulas have been used by different authors to calculate relative growth rate (Kain, 1987; Lipkin et al., 1986) and because different culture methods have been used. Field measurements of Gracilaria growth rates are scarce and the rates are slower than those under optimum culture conditions.

Growth rates of Gracilaria spp. under field conditions range from 2 to $12 \% \cdot \mathrm{d}^{-1}$ (Table 3.2) and growth rates of $G$. sordida in field culture range from $1-5 \%$. $\mathrm{d}^{-1}$ (Luxton, 1977; Pickering; 1990). A growth rate of above $3.5 \% . \mathrm{d}^{-1}$ is considered good in commercial cultivation (Luxton et al., 1987). 
Table 3.2. The relative growth rates $\left(\% . \mathrm{d}^{-1}\right)$ of species of Gracilaria.

\begin{tabular}{|c|c|c|c|c|}
\hline Species & $* *$ Location & Condition & RGR & Ref \\
\hline & & & & \\
\hline G.cf.verrucosa & Canada & Field & $2-4.7$ & 1 \\
\hline G. tikvahiae & Canada & Field & 10 & 2 \\
\hline G. tikvahiae & USA & $\mathrm{Lab}$ & $2.2-5.7$ & 3 \\
\hline G. bursapastoris & USA & Tanks & 12 & 4 \\
\hline G. coronopifolia & USA & Tanks & 6.5 & 4 \\
\hline G. foliifera & USA & Field & 5.2 & 5 \\
\hline G. tikvahiae & USA & Lab & $12-20$ & 6 \\
\hline$G$. verrucosa & Norway & $\mathrm{Lab}$ & $4-9$ & 7 \\
\hline G. edulis & Micronesia & Lab & $2.5-5.1$ & 8 \\
\hline G. arcuata & Micronesia & Lab & $2.1-3.5$ & 8 \\
\hline G. foliifera & Israel & Tanks & $9.9-12.8$ & 9 \\
\hline G. verrucosa & China & Field & $5-12$ & 10 \\
\hline G. confervoides & Taiwan & Ponds & 7 & 11 \\
\hline G. edulis & India & Field & 2.2 & 12 \\
\hline G. verrucosa* & Thailand & Field & 6.7 & 13 \\
\hline G. sordida & $\mathrm{NZ}$ & Field & $1-4.6$ & 14 \\
\hline \multirow[t]{3}{*}{ G. sordida } & $\mathrm{NZ}$ & Tanks & 3 & 15 \\
\hline & & Spray & 6 & 15 \\
\hline & & Glass tube & 47 & 15 \\
\hline G. sordida & $\mathrm{NZ}$ & Field & $3.3-4.9$ & 16 \\
\hline
\end{tabular}




\section{References.}

1. Saunders and Lindsay, 1979. 2. Edelstein et al., 1981. 3. Edelstein et al., 1976. 4. Hoyle, 1978. 5. Rosenberg and Ramus, 1981. 6. Parker, 1982. 7. Rueness and Tananger, 1984. 8. Nelson et al., 1980. 9. DeBoer et al., 1978. 10. Ren et al., 1984, 11. Shang, 1976. 12. Raju and Thomas, 1971. 13. Mumford, 1987. 14. Luxton, 1977. 15. Lignell and Pedersen, 1987. 16. Pickering, 1990.

* now classified as Polycavernosa fisheri (Abbott, 1988)

**Location $=$ origin of weed not location of study 
Estimates of productivity have been reported for many Gracilaria species and in some cases the rates are relatively high. However, like growth rates, most of these have been determined over relatively short periods of time since it has been difficult to sustain production for prolonged periods (McLachlan and Bird, 1986). Furthermore, high levels of production have been attained in small-scale culture, but the levels of production reported for field conditions are not outstanding, the usual range in values being 1-6 t.ha-1 $\mathrm{y}^{-1}$ (Friedlander and Lipkin, 1982; Hollenbeck, 1987; Li et al., 1984; Santelices et al., 1984; Saunders and Lindsay, 1979; Smith et al., 1984). In Taiwanese pond culture of Gracilaria, average annual production rates of $10-13 \mathrm{t}^{-h a^{-1}} \mathrm{y}^{-1}(\mathrm{dw})$ are obtained (Shang, 1976). New Zealand Gracilaria is expected to produce higher yields of 20-35 t.ha-1 $\mathrm{y}^{-1}$ (Terzaghi et al., 1987). Johnson (1981) estimated production of $G$. sordida in non-aerated tank culture to be 18.3 t.ha ${ }^{-1} \mathrm{y}^{-1}$ (dw) which is similar to estimated production of this study. However, it is important to note that estimate of annual production for the farm in this study is conservative because the plants were cropped back twice by theft.

\subsection{CONCLUSION.}

In conclusion, it can be said that a year-long pilot-scale cultivation of $G$. sordida in Pauatahanui Inlet, Porirua Harbour, has shown that this seaweed can be grown from spores or fronds on artificial substrates. Of the artificial substrates tested, the best one for spore attachment was polypropylene rope, and the growth rate on this substrate was greatest in spring. G. sordida gave high annual production and satisfactory relative growth rate.

Problems encountered during field culture included epiphytes, sedimentation, storm damage and theft.

Gracilaria cultivation in this country could be a promising investment. However, the following requirements need to be met: 
1) selection of appropriate materials as seed stock, preferably fast growing and high-agar-quality strains;

2) selection of appropriate sites; and

3) selection of appropriate culture methods and time of harvesting.

From an aquacultural perspective, it appears that the site selection for cultivation of Gracilaria is very important. The principal factors affecting growth which should be considered in selecting a site are light, temperature, salinity and nitrogen levels. A protected site which has plenty of sunshine, moderate fluctuation in temperature and moderate fresh water input rather than constant oceanic salinity should be ideal (Daugherty and Bird, 1988; Terzaghi et al., 1987).

G. sordida may be suited to culture in a protected site with shallow brackish water such as a pond or breakwater-confined area, as suggested by Christeller and Laing (1989) and Terzaghi et al. (1987). The choice of culture method (sporulation or vegetative propagation) depends on a variety of factors including relative cost and effort. The culture technique, involving outplanting, in harbour, nets or ropes containing spores or plant fragments has been shown to be successful. However, the labour requirements of this operations are large so their economic viability is based on the low cost of labour, as in developing countries in Southeast Asia. To date, cheap, labour- intensive systems are the only economically viable Gracilaria cultivation. In contrast, high technological systems (energy intensive) are not yet economically viable. 


\title{
CHAPTER 4
}

\section{YIELD AND GEL STRENGTH OF AGAR FROM A RANGE OF POPULATIONS}

OF

\author{
GRACILARIA SORDIDA
}

\subsection{INTRODUCTION.}

The red seaweed genus Gracilaria has gained commercial interest because it can be used for many purposes. As a natural organic compound, agar has no replacement for many of its uses. Consequently, the demand for agar continues to rise, and a critical shortage of high quality agar is predicted for the future (Mathieson, 1981). Presently the bulk of agar seaweeds comes from natural harvests but these are unreliable, being dependent not only on unpredictable yearly variations, but also on world economic and political conditions, and are not able to keep up with rising demand.

Increasing demand for Gracilaria has led to studies on the growth rate and properties and yield of its agar under a wide range of environmental conditions and also to the development of a wide variety of Gracilaria cultivation techniques (Lignell, 1986).

The feasibility of farming Gracilaria in New Zealand has been investigated, in both laboratory and field experiments, by Luxton (1977), Johnson (1981), Olsen (1986), Christeller and Laing (1989), Pickering (1990), Pillai (unpubl.) and Intasuwan (unpubl.)

The interest in mariculture of Gracilaria has led to the screening of many species/populations to find those with desirable qualities. Agar yield, gel strength, gelation and melting temperature, colour and viscosity are principal factors determining commercial values of Gracilaria (Kim, 1970; Tam and Edwards, 1982). 
Worldwide studies on numerous Gracilaria spp. have shown a wide range of results indicating considerable variation in yield or quality as a function of many factors. The factors that have been shown to cause variation in agar quantity and quality in both aquacultured and in situ populations include the following:

1) Species (Hoyle, 1978; Yang, 1982; Cote and Hanisak, 1986; Lahaye et al., 1986; Bird et al., 1987; Durairatnam, 1987).

2) Genetic differences within species (Patwary and van der Meer, 1983).

3) Population (Tam and Edwards, 1982; Shi et al., 1988).

4) Life history phase (Whyte et al., 1981; Lignell, 1988).

5) Thallus age (Craigie and Wen, 1984; Bird et al., 1987).

6) Seasonal changes (Hoyle, 1978; Oza, 1978; Asare, 1980; Wang and Yang, 1980; Whyte et al., 1981; Durairatnam, 1987; Miller and Furneaux, 1987; Pickering, 1990; Intasuwan, 1990).

7) Nitrogen concentration of the seawater (Hoyle, 1978; DeBoer, 1979; Bird et al., 1981; Craigie and Wen, 1984; Laing et al., 1989; Pickering, 1990).

8) Temperature (Wang and Yang, 1980; Laing et al., 1989).

9) Salinity (Bird, 1988; Daugherty and Bird, 1988).

10) Method of agar extraction and pretreatment procedures (Santos, 1980; Durairatnam, 1987).

11) Culture conditions (DeBoer, 1978; Bird et al., 1981; Craigie and Wen, 1984; Cote and Hanisak, 1986; Rotem et al., 1986; Friedlander et al., 1987).

Most Gracilaria species produce agars of low gel quality. These agars are elastic, and have low gel strength and high gelling and melting temperature (Santos, 1980). However, it is well known that the gel strength of many Gracilaria agars can be improved by pretreating the harvested weed with alkali (Duckworth et al., 1971; Friedlander et al., 1981; Nelson et al., 1983; Patwary et al., 1983; Craigie and Wen, 1984) which converts L-galactose-6-sulphate to 3,6-anhydro-L-galactose.

The purpose of the present study was to determine and compare the agar yield and gel 
strength of $G$. sordida from a wide range of populations and compare agar yield and gel strength of native and alkali treated weeds, both from wild grown samples and from cultured samples. In this study, it was decided to concentrate on the native, unmodified agars because if a high gel strength agar can be obtained without an alkali treatment, it may be more attractive from an economic standpoint. This knowledge is valuable in assessing the most suitable seed stock and potential site for mariculture and the best management options for the crop.

\subsection{MATERIALS AND METHODS.}

\subsubsection{Plant materials.}

Gracilaria sordida samples were randomly collected from 23 sites between 1987 and 1989. All samples, with exception of that from Havelock (November 1989) were collected in the summer months of December and January. These sites, ordered from North to South, were as follows (see Figure 4.1 and Appendix 8):

1.Shelly Beach (ShB), Kaipara Harbour (36 34'S, $\left.174^{\circ} 23^{\prime} E\right)$

2.Puketutu Island (Pkt), Manukau Harbour, Auckland (36 58'S, $174^{\circ} 44^{\prime} \mathrm{E}$ )

3.Hillsborough Bay (HiB), Manukau Harbour, Auckland (36 $\left.56^{\prime} \mathrm{S}, 174^{\circ} 45^{\prime} \mathrm{E}\right)$

4.Blockhouse Bay (Blh), Manukau Harbour, Auckland (36 $55^{\circ} \mathrm{S}, 174^{\circ} 44^{\prime} \mathrm{E}$ )

5.Armour Bay (Arm), Manukau Harbour, Auckland (36 $56^{\prime} \mathrm{S}, 174^{\circ} 43^{\prime} \mathrm{E}$ )

6.Firth of Thames (Tha), Thames (37 $\left.09^{\prime} \mathrm{S}, 175^{\circ} 33^{\prime} \mathrm{E}\right)$

7.Whitianga Harbour (Whi), Whitianga ( $\left.36^{\circ} 49^{\prime} \mathrm{S}, 175^{\circ} 44^{\prime} \mathrm{E}\right)$

8. Whangamata Harbour (Wha), Whangamata (37 $\left.12^{\prime} \mathrm{S}, 175^{\circ} 53^{\prime} \mathrm{E}\right)$

9.Tauranga Harbour (Tau), Mount Maunganui (3751'S, $\left.176^{\circ} 13^{\prime} \mathrm{E}\right)$

10.Ohiwa Harbour (Ohi), Kutarere ( $\left.38^{\circ} 02^{\prime} \mathrm{S}, 177^{\circ} 07^{\prime} \mathrm{E}\right)$

11.Napier Harbour (Nap), Napier (39³0'S, $\left.176^{\circ} 54^{\prime} \mathrm{E}\right)$

12.Riversdale (Rid), Mouth of Whareama River ( $\left.41^{\circ} 01^{\prime} \mathrm{S}, 176^{\circ} 05^{\prime} \mathrm{E}\right)$

13.Scorching Bay (Sch), Wellington Harbour ( $\left.41^{\circ} 16^{\prime} \mathrm{S}, 174^{\circ} 51^{\prime} \mathrm{E}\right)$

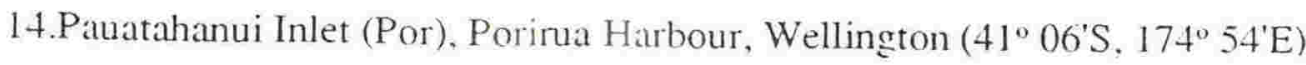


15.Puponga Inlet (Pup), Cape Farewell, Collingwood (40 $32^{\prime} \mathrm{S}, 172^{\circ} 44^{\prime} \mathrm{E}$ )

16.Rabbit Island (Rab), Nelson $\left.41^{\circ} 16^{\prime} \mathrm{S}, 173^{\circ} 09^{\prime} \mathrm{E}\right)$

17. Havelock (Hav), Callens Point ( $\left.41^{\circ} 17^{\prime} \mathrm{S}, 173^{\circ} 46^{\prime} \mathrm{E}\right)$

18.Avon-Heathcote Estuary (Avo), Christchurch (43 $32^{\prime} \mathrm{S}, 172^{\circ} 44^{\prime} \mathrm{E}$ )

19.Aramoana (Ara), Otago Harbour, Dunedin ( $\left.45^{\circ} 47^{\prime} \mathrm{S}, 170^{\circ} 42^{\prime} \mathrm{E}\right)$

20.Papanui Inlet (Pap), Otago Harbour, Dunedin ( $45^{\circ} 51^{\prime} \mathrm{S}, 170^{\circ} 42^{\prime} \mathrm{E}$ )

21.Pounawea (Pou), Catlins Lake (46 $\left.29^{\prime} \mathrm{S}, 169^{\circ} 41^{\prime} \mathrm{E}\right)$

22.Riverton (Rit), Invercargill ( $\left.46^{\circ} 22^{\prime} \mathrm{S}, 168^{\circ} 01^{\prime} \mathrm{E}\right)$

23.Bluff (Blf), Invercargill ( $\left.46^{\circ} 34^{\prime} \mathrm{S}, 168^{\circ} 20^{\prime} \mathrm{E}\right)$ 


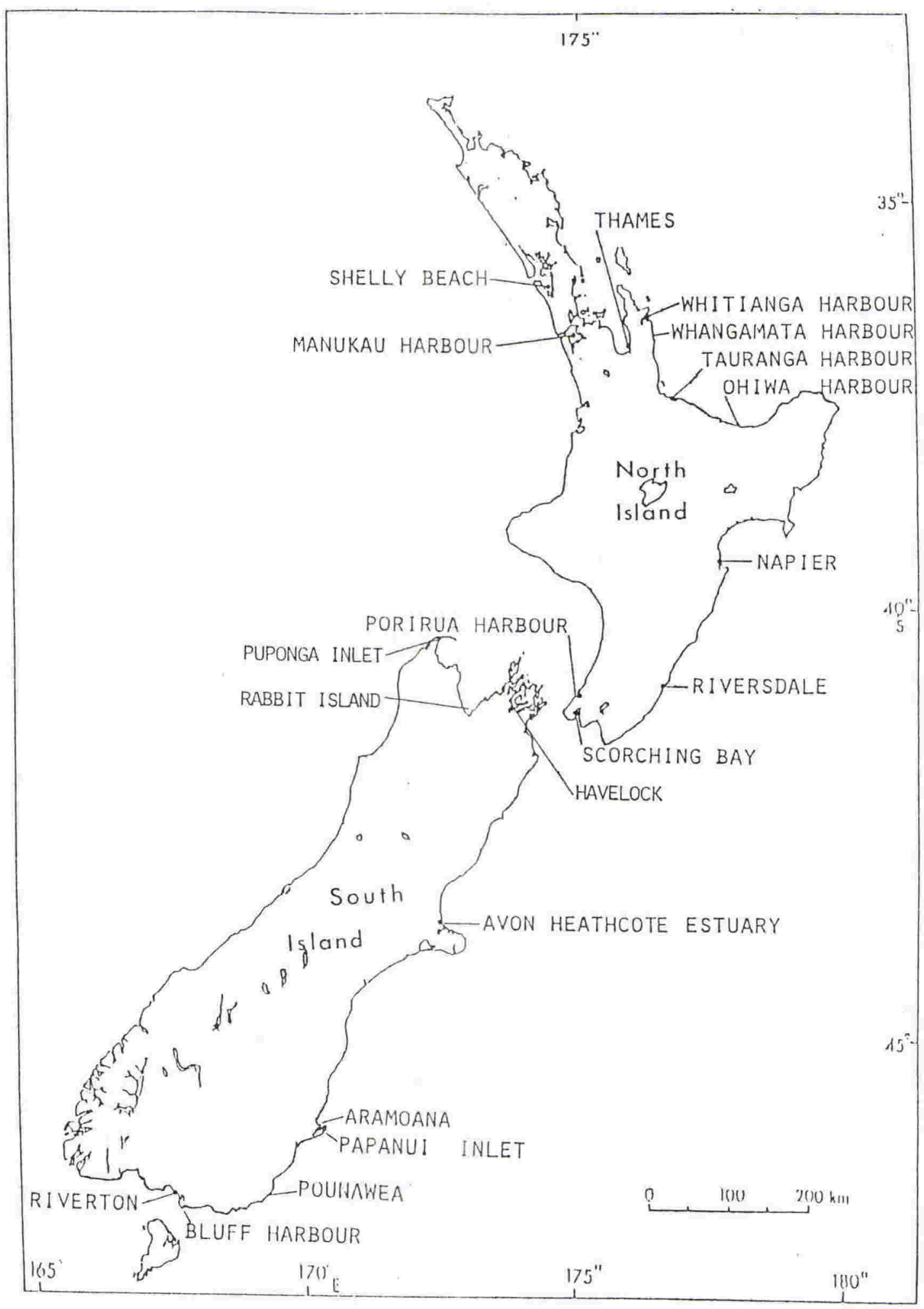

Figure 4.1. Map of New Zealand showing the collection sites for agar analysis. 
Most of the samples were collected directly from the field by the author. Those from Puponga Inlet, Rabbit Island and Havelock were collected by A. Riwaka (Kiwa Aquaculture) and supplied by Dr Richard Furneaux (Chemistry Division, DSIR), and the samples from Aramoana, Papanui Inlet, Pounawea and Riverton were collected by Mr. Carl Stapleton and Drs Betty and Eric Terzaghi. All of the samples supplied by other people cited above were collected in summer except the sample from Havelock which was collected in November 1989.

In addition to the wild-harvested samples of $G$. sordida, samples of $G$. secundata were collected from Island Bay, Wellington, to analyse the agar quality of another New Zealand Gracilaria species in parallel.

The plants from each locality were washed thoroughly with seawater and then tap water, and epiphytes were removed. The plants were then examined under a microscope and separated according to life-cycle stage (tetrasporophyte, female, male and sterile). Male and sterile plants were usually rare and only tetrasporophytes plants were consistently present, so for the purpose of this thesis it was decided to concentrate on tetrasporophyte only. The tetrasporophytes from each locality were weighed and separated into two batches. The first batch was dried in an oven at $60^{\circ} \mathrm{C}$ for $48 \mathrm{~h}$ and agar was extracted. The second batch was cultured in 301 plastic bags for 56 days and later extracted for agar using the same procedure as for the first batch.

\subsubsection{Laboratory cultivation}

The cleaned G. sordida was cultivated in plastic bags with continuous aeration (Plate 4.1). Each bag contained 301 of PES medium (Provasoli, 1968) in seawater at a salinity of $35 \%$, and was inoculated with $150 \mathrm{~g}$ of seaweed. Light was provided continuously by cool-white fluorescent tubes and light intensity was maintained at $200 \mathrm{nE} \cdot \mathrm{m}^{-2} \cdot \mathrm{sec}^{-1}$. The culturing was carried out at ambient temperatures (approximately $20^{\circ} \mathrm{C}$ ) because constant temperature facilities were not available. Two replicate bags were set up for each locality, and the cultures allowed to acclimate for one week prior to the experimental period of two 
months. The culture medium was changed weekly. In order to calculate relative growth rate (\% fresh weight. $\mathrm{d}^{-1}$ ) the fresh weight of the seaweed was also measured at weekly intervals, using a top loading balance. The biomass harvested at the end of the experimental period was used for agar extraction and for the analysis of proteins by electrophoresis (Chapter 5). Because both time and culture space were limited, it was possible to culture only enough material for native agar extraction, not for alkaline extraction and not all localities could be included (see Table 4.1).

This experiment was carried out using the facilities at Mahanga Bay Shellfish Hatchery (Ministry of Agriculture and Fisheries, MAF) and Victoria University Marine Laboratory, Island Bay, Wellington. 


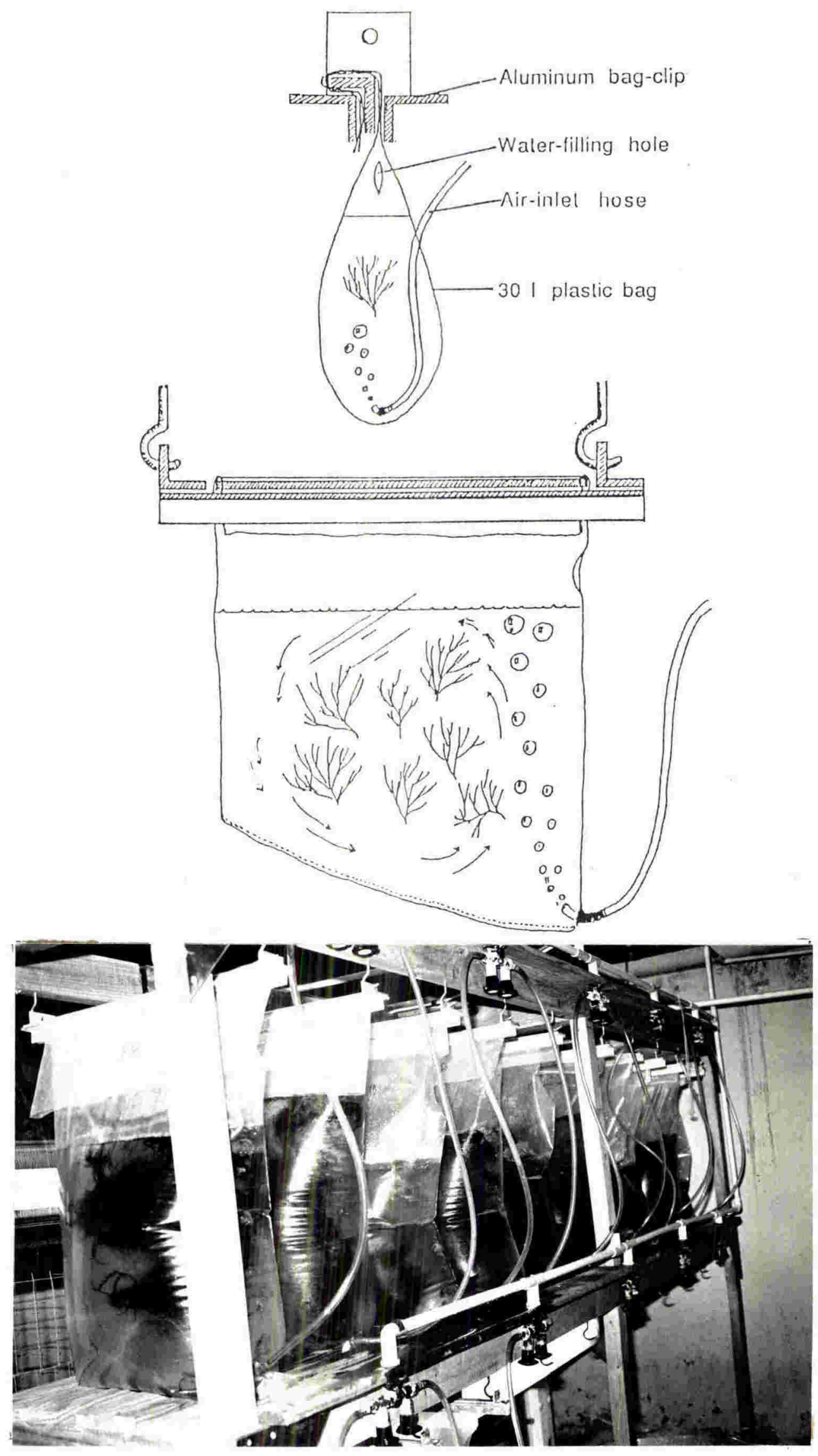

Plate 4.1. 301 plastic culture bags. 


\subsubsection{Native (non alkali-treated) agar extraction method.}

The agar extraction method followed that of Pickering (1990) as described below and summarised in Figure 4.2.

Dried seaweed samples of $10 \mathrm{~g}$ (two replicates of wild-collected material and two replicates of cultured material per locality) were placed in a weed washer connected to a distilled water tank, and washed in running distilled water for $2 \mathrm{~h}$ to remove cold-water solubles. They were then redried and placed in a $500 \mathrm{ml}$ beaker with $290 \mathrm{ml}$ distilled water and $10 \mathrm{ml}$ of phosphate buffer $\left(5 \% \mathrm{NaH}_{2} \mathrm{PO}_{4}\right)$, and the $\mathrm{pH}$ was adjusted to 6.0 with $1 \mathrm{M}$ $\mathrm{NaOH}$. The samples were then autoclaved at $120^{\circ} \mathrm{C}$ for $30 \mathrm{~min}$. The gel solutions were filtered hot through two layers of muslin (mutton cloth), then filtered under suction through Whatman 541 filter paper. The filtrates were allowed to gel at room temperature in an aluminium tray. The gels were frozen ovemight, then thawed at room temperature. The thaw water was drained, and the gels were washed briefly with distilled water. The gels were then dried at $60^{\circ} \mathrm{C}$ and the constant dry weight recorded as the agar yield. The dry agar was cut and powdered in a hammer mill, then kept in glass vials for use in measuring gel strength and gelling and melting temperatures. 


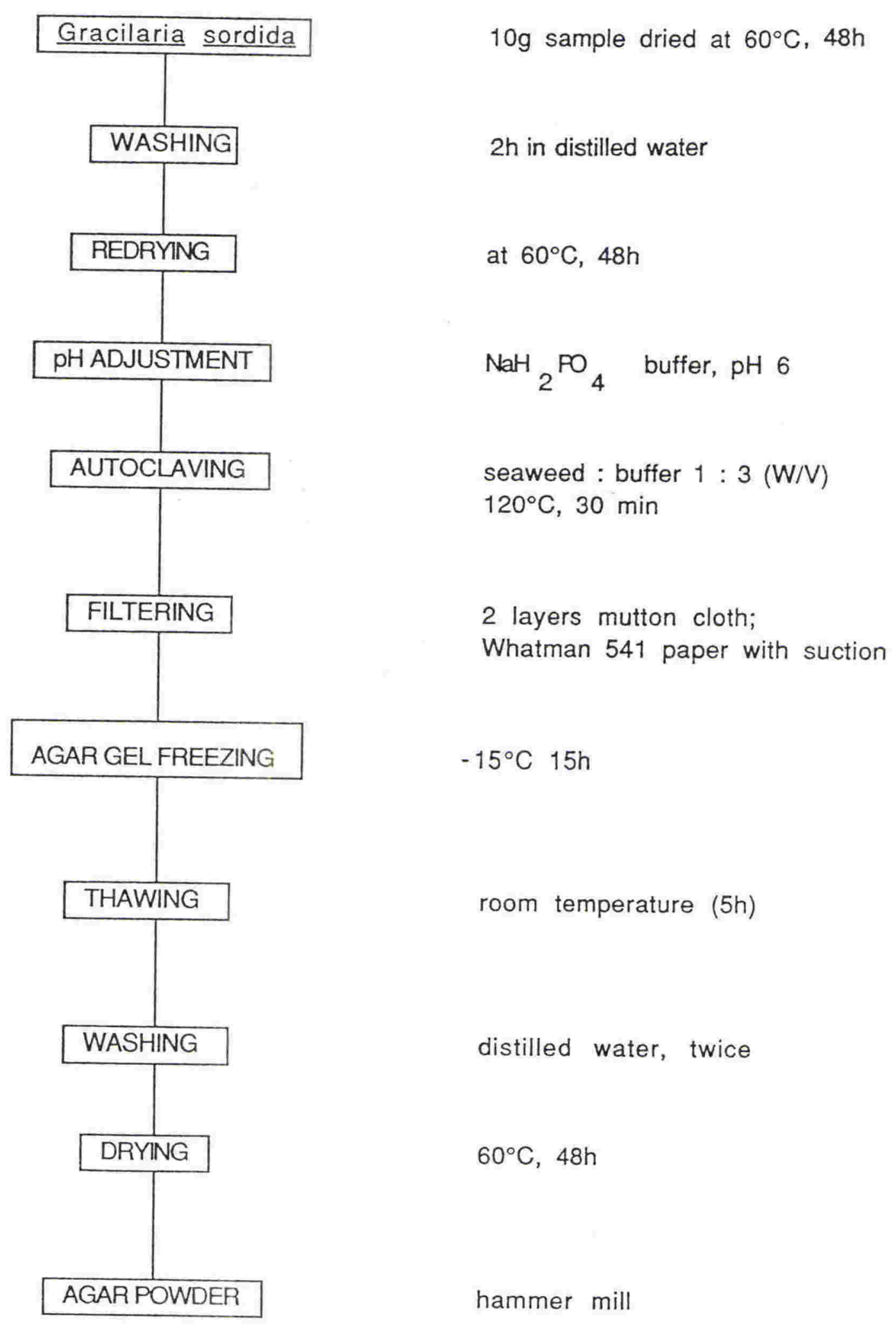

Figure 4.2. Flow diagram of the agar extraction process. 


\subsubsection{Alkali pretreatment.}

The method used for alkali pretreatment followed the method described by Christeller and Laing (1989). Dry seaweed samples of $10 \mathrm{~g}$ (two replicates per locality) were treated with $200 \mathrm{ml}$ of alkaline solution $\left(4 \% \mathrm{NaOH}, 0.3 \% \mathrm{NaBH}_{4}\right)$ for $2 \mathrm{~h}$ at $90^{\circ} \mathrm{C}$. The solutions were then discarded and the treated samples were washed in distilled water. The samples were then placed in $300 \mathrm{ml}$ of distilled water, the $\mathrm{pH}$ was adjusted to $6.5-7.0$ with $\mathrm{H}_{3} \mathrm{PO}_{4}$ (70 xl), and the samples then autoclaved. Purification of the alkali-treated agar followed the same method as that described above for native agar extraction.

\subsubsection{Determination of gel strength, and gelling and melting temperature.}

A $1.5 \%$ agar solution was made by dissolving $1.5 \mathrm{~g}$ powdered agar in $100 \mathrm{ml}$ boiling distilled water and was poured into four plastic cups, $25 \mathrm{ml}$ into each, to make four replicate gels. The gels were allowed to set overnight at $20^{\circ} \mathrm{C}$.

Gel strength of the four replicate samples was determined with a water-filled plunger as described by Pickering (1990). The plunger had a diameter of $1 \mathrm{~cm}$ and a water flow rate of $200 \mathrm{ml}$ per minute (see Plate 4.2). Gel strengths were expressed as g. $\mathrm{cm}^{-2}$ and are reported as mean $\pm 2 \times S D$.

Gelling temperature was determined using the procedure described by Guerin and Bird (1987). A $1.5 \%$ agar solution was made and $1 \mathrm{ml}$ samples of this were introduced into $10 \mathrm{x}$ $75 \mathrm{~mm}$ test tubes. By slanting and periodically righting the rack of test tubes containing the melted agar, the temperature at which the meniscus no longer remained horizontal was determined and recorded as the gelling temperature.

Gel melting temperature was determined using the procedure of Craigie and Leigh (1978). Tubes of agar solution were prepared as described above, then cooled ovemight at $4^{\circ}$ C. A $5 \mathrm{~mm}$ glass bead was placed on the surface of each gel and the tubes were 
equilibrated in a well-stirred water bath at $30^{\circ} \mathrm{C}$ for $10 \mathrm{~min}$. Melting temperature was recorded as the temperature at which a glass bead sank through the agar when this was gradually heated in the water bath $\left(1^{\circ} \mathrm{C}\right.$ min $\left.^{-1}\right)$.

Gel of $1.5 \%$ Davis Gelatine agar was used as a control in determining gel strength, gelling and melting temperatures.

\subsubsection{Statistical analysis.}

For each locality and type of agar (namely native and alkali-extracted agar from wild weed and native agar from cultured weed), the means for agar yield, gel strength, gelling temperature and melting temperature were compared with one another by pairwise t-tests. A difference between two means was considered significant if probability $(p)>Z<0.05$. On table 4.1 and all figures the values represent the mean $( \pm 2 \times S D)$ of eight individual measurements, four from each of the two agar samples extracted $(n=8)$. 

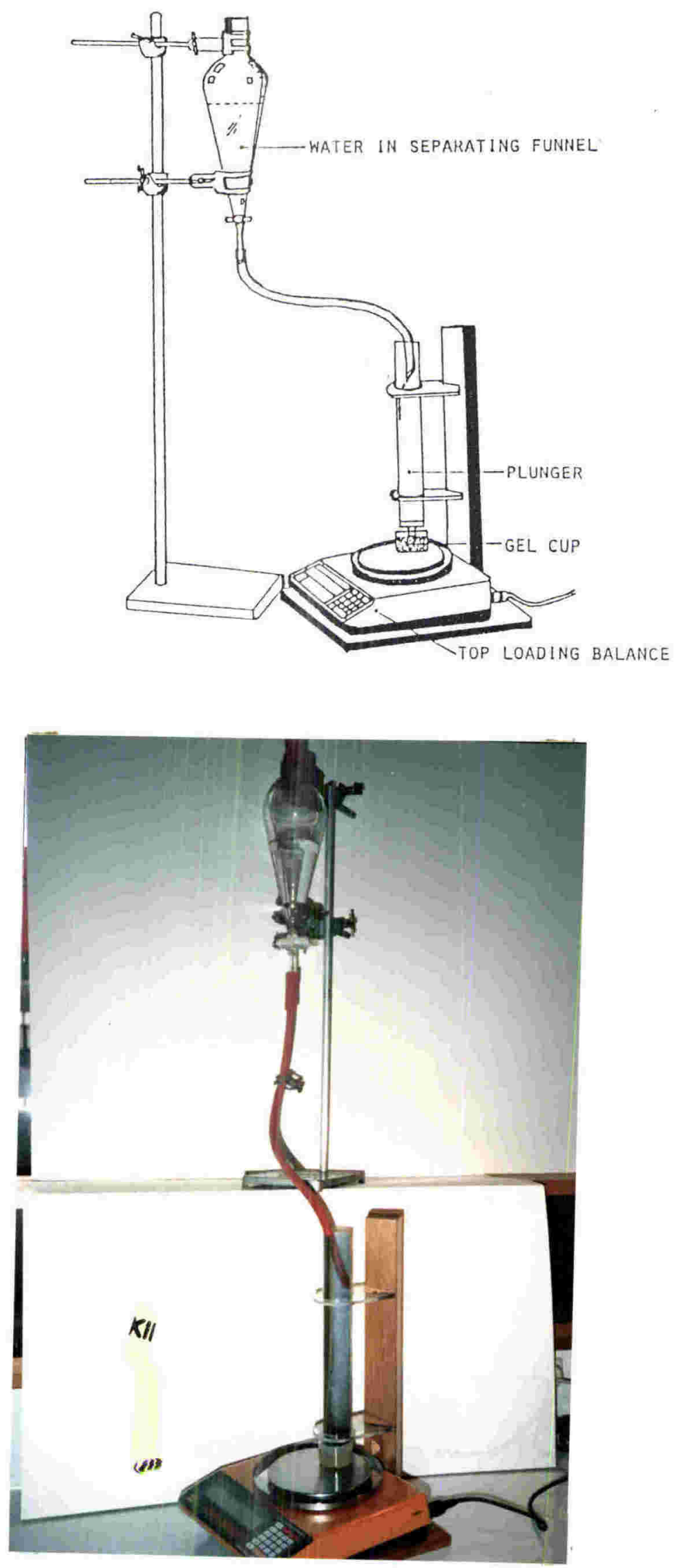

Plate 4.2. Gel testing equipment. 


\subsection{RESULTS.}

The results of the analysis of agar from tetrasporophytes of $G$. sordida and $G$. secundata from different sites are presented in Table 4.1. and Figure 4.3 to 4.6. 


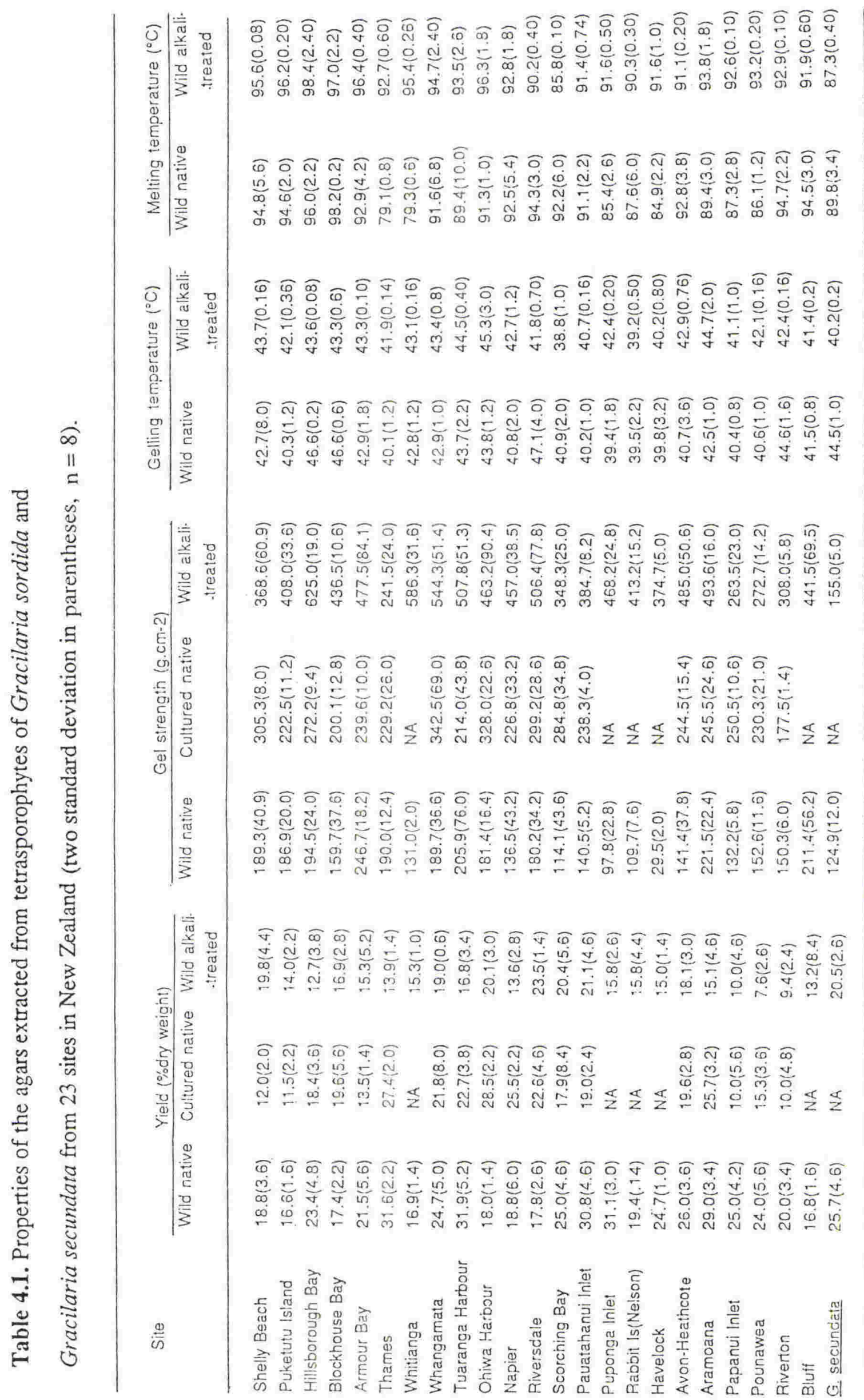




\subsubsection{Agar yield.}

The yield of native agar from G. sordida tetrasporophytes expressed as percent dry weight, varied from 17 and $32 \%$ with a mean of $23.1 \%$ (see Table 4.1 and Figure 4.3). The highest yields were obtained from Thames Gracilaria, and the lowest yields were obtained from the Puketutu Island population. The native agar yield from G. secundata was $25.7 \%$.

The yield of native agar from cultured samples ranged from $10 \%$ to $29 \%$ with a mean of $18.9 \%$. The highest yields were obtained from Ohiwa Gracilaria and the lowest yields were obtained from the Papanui Inlet and Riverton populations.

The yield of alkali-pretreated agar ranged from $9 \%$ to $24 \%$ with a mean of $15.9 \%$. The highest alkali agar yields were obtained from the Riversdale population and the lowest alkali yields were obtained from Papanui Inlet and Riverton Gracilaria. The agar yield from cultured samples and especially from alkali-pretreated samples was lower than from wild-harvested samples in most cases. 
Mean agar yield of wild native agar

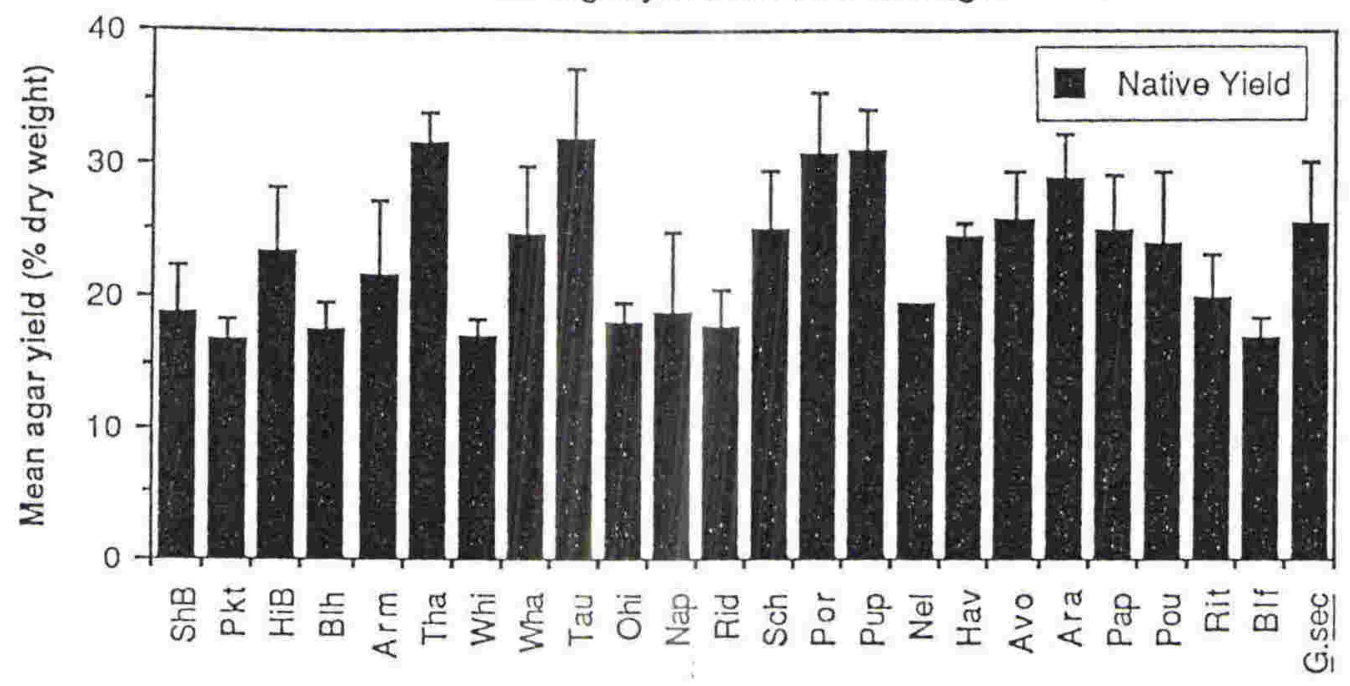

Mean agar yleld of cultured natlve agar

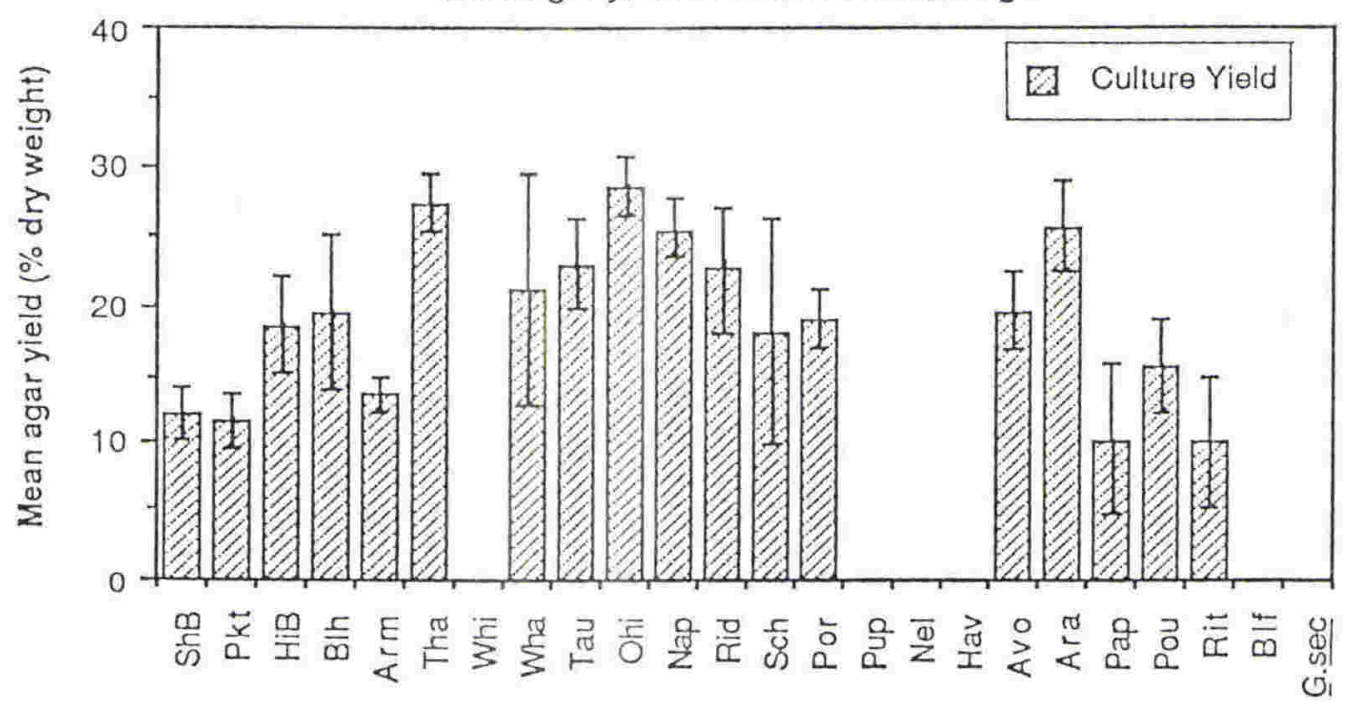

Mean agar yleld of wild alkall-treated agar

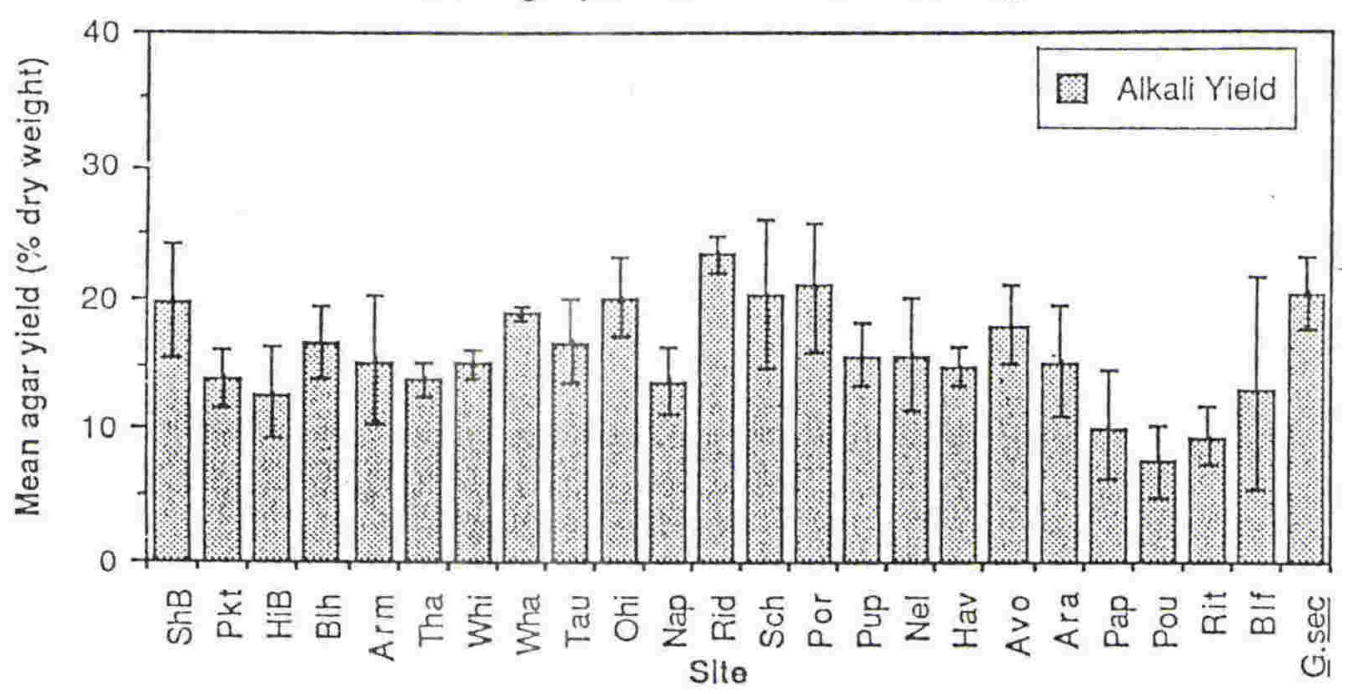

Figure 4.3. Mean agar yields (\% dry weight) of Gracilaria sordida and Gracilaria secundata tetrasporophytes from different sites. Vertical bars represent $95 \%$ confidence limits (mean $\pm 2 \times \mathrm{SD})$. 


\subsubsection{Agar gel strength.}

Agar gel strength of $G$. sordida tetrasporophytes obtained from wild-harvested seaweed ranged from $29.5 \mathrm{~g} . \mathrm{cm}^{-2}$ to $307 \mathrm{~g} . \mathrm{cm}^{-2}$ with a mean of $159 \mathrm{~g} . \mathrm{cm}^{-2}$ (Figure 4.4), the highest strength being obtained from the Blockhouse Bay population and the lowest from the Havelock population.

Agar gel strength from alkali-pretreated seaweed ranged from 230 g.cm-2 to 625 g.cm-2 with a mean of $417.9 \mathrm{~g} . \mathrm{cm}^{2}$. The highest gel strength of alkali-pretreated agar was obtained from the Hillsborough Bay population.

Agar gel strength from cultured samples ranged from 177 g.cm-2 to 342 g.cm ${ }^{-2}$ with a mean of $252.8 \mathrm{~g} . \mathrm{cm}^{2}$, the highest strength being obtained from the Whangamata Harbour population and the lowest from the Riverton population.

Native agar gel strength from $G$. secundata was $124.5 \mathrm{~g} . \mathrm{cm}^{-2}$. Gel strength of alkali-pretreated agar was $155 \mathrm{~g} . \mathrm{cm}^{-2}$. The gel strength of $G$. secundata samples showed very little improvement with alkali treatment compared with most $G$. sordida. 

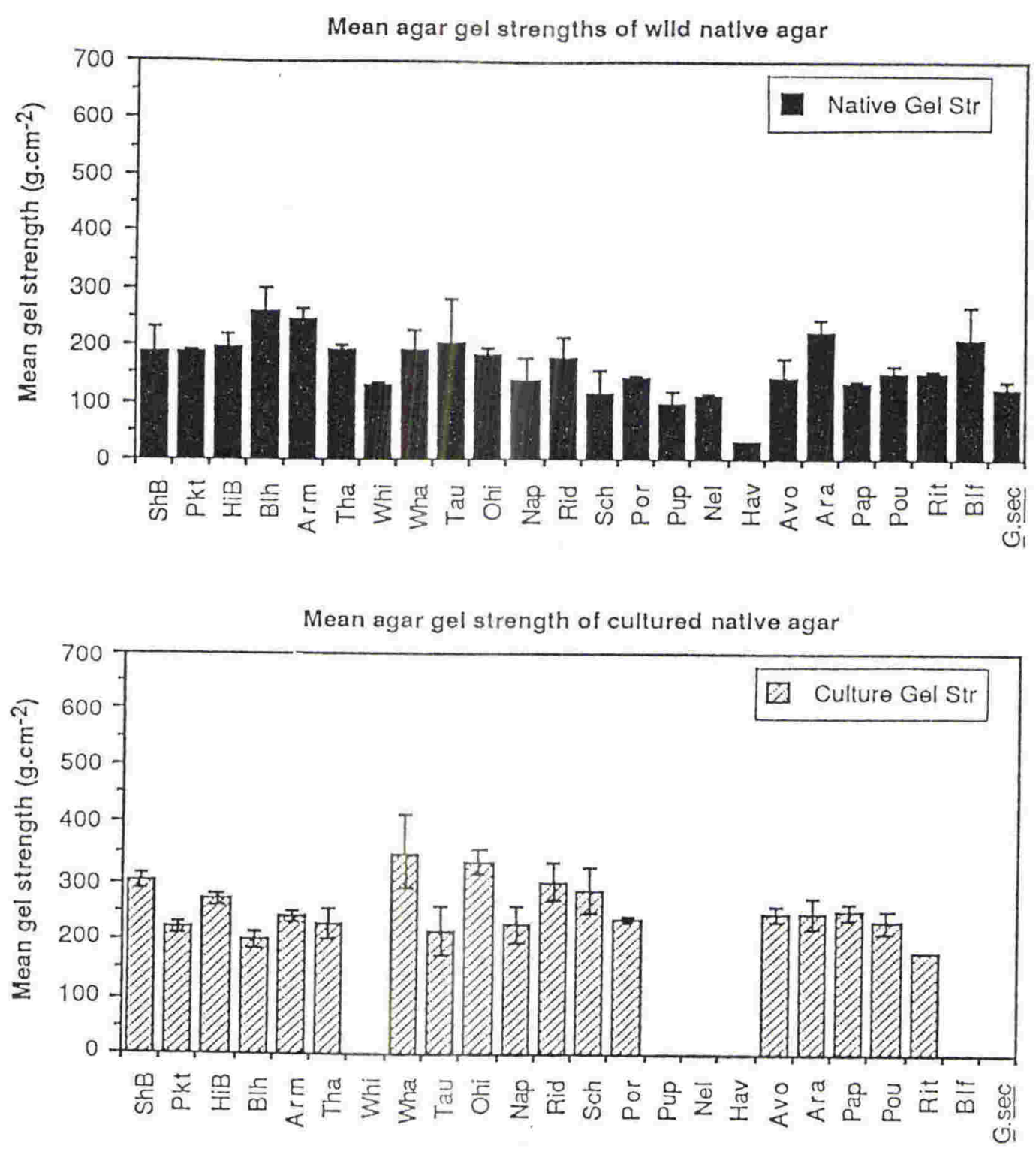

Mean agar gel strength of wild alkall-treated agar

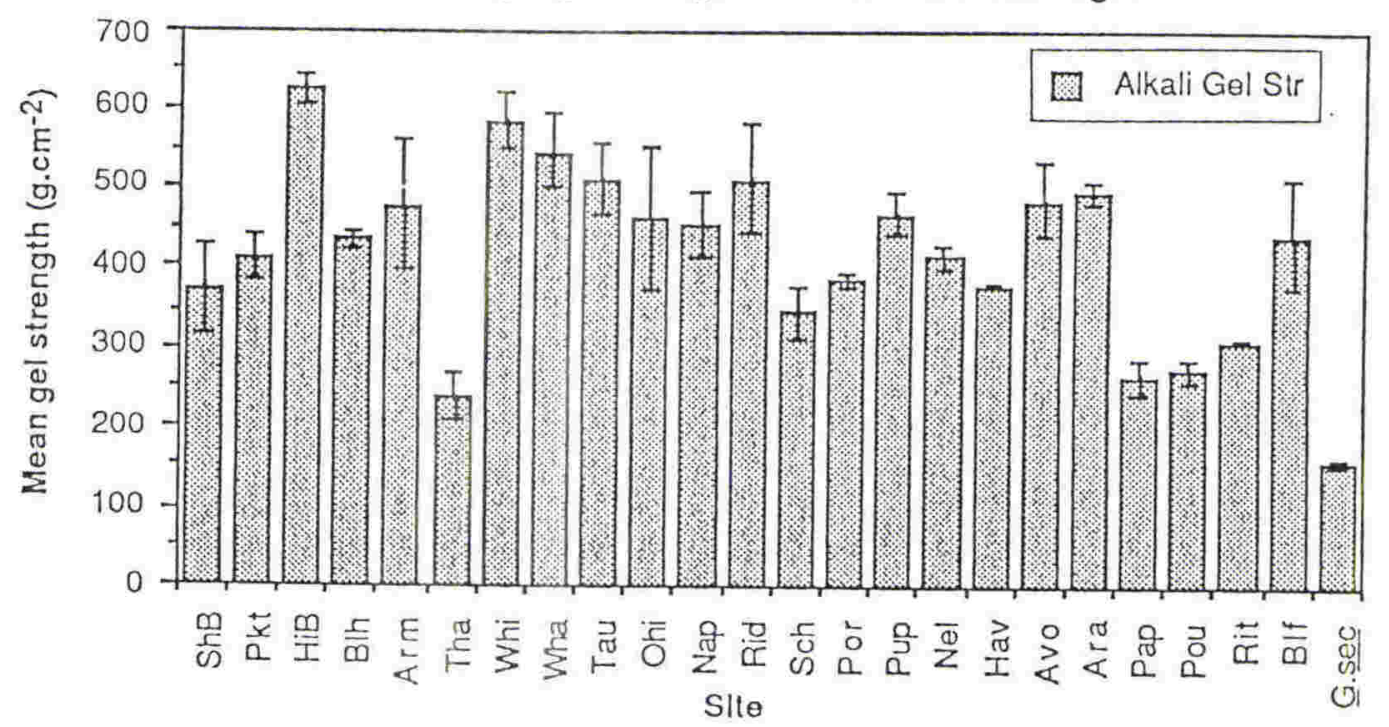

Figure 4.4. Comparison of mean agar gel strengths $\left(\mathrm{g} . \mathrm{cm}^{-2}\right)$ from Gracilaria sordida and Gracilaria secundata tetrasporophytes from different sites. Vertical bars represent $95 \%$ confidence limits (meant $2 \times \mathrm{SD}$ ). 


\subsubsection{Gelling temperature.}

The gelling temperature of native agar from tetrasporophyte plants of G. sordida ranged from 39 to $47^{\circ} \mathrm{C}$ (Figure 4.5) with a mean of $42.2^{\circ} \mathrm{C}$. The material from Puponga Inlet had the lowest gelling temperature while the material from Riversdale had the highest gelling temperature.

The gelling temperature of the alkali-pretreated agar ranged from $38^{\circ} \mathrm{C}$ to $45^{\circ} \mathrm{C}$ with a mean of $42.3^{\circ} \mathrm{C}$. The samples from Scorching Bay had the lowest gelling temperature and the samples from Ohiwa Harbour had the highest gelling temperature.

The native gelling temperature of $G$. secundata was $44.5^{\circ} \mathrm{C}$ and the alkali gelling temperature was $40.2^{\circ} \mathrm{C}$.

Thus, the gelling temperature of alkali-pretreated agar was generally very slightly higher than that of native agar except from Hillsborough Bay, Blockhouse Bay, Riversdale, Scorching Bay, Riverton and G. secundata populations. 

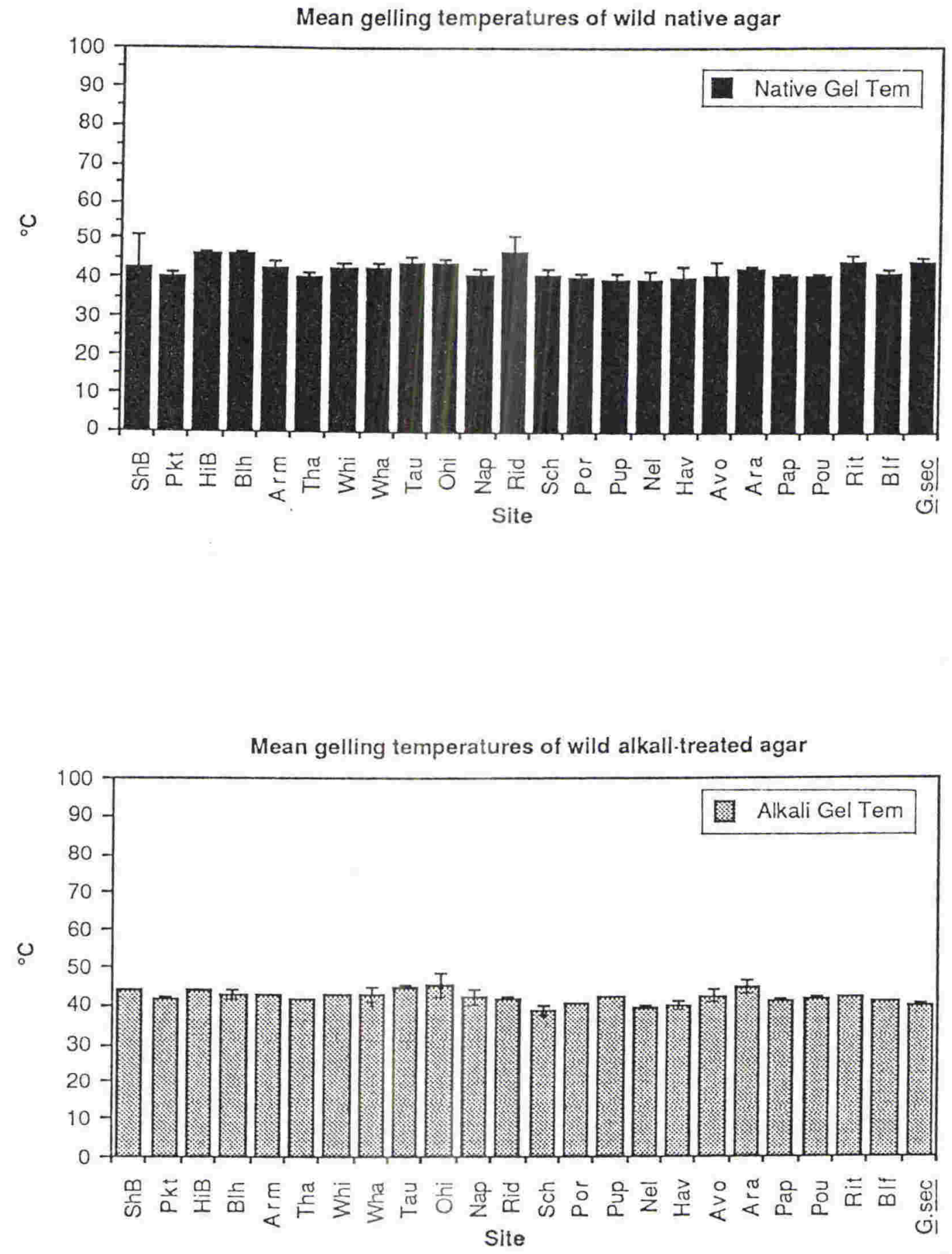

Figure 4.5. Mean gelling,temperature of the agar of Gracilaria sordida and Gracilaria secundata tetrasporophytes from different sites.

Vertical bars represent $95 \%$ confidence limits (mean $\pm 2 \times \mathrm{SD}$ ). 


\subsubsection{Melting temperature.}

The melting temperature of the native agar from tetrasporophyte plants of $G$. sordida ranged from 79 to $98^{\circ} \mathrm{C}$ with a mean of $90.4^{\circ} \mathrm{C}$. (Figure 4.6). The lowest was obtained from the Thames population and the highest was obtained from the Blockhouse Bay population.

The melting temperatures of the alkali-treated agar ranged from 85 to $98^{\circ} \mathrm{C}$ with a mean of $93.0^{\circ} \mathrm{C}$. The lowest alkali melting temperature was obtained from the Scorching Bay population, and the highest from Hillsborough Bay. Thus, the melting temperature of the alkali-treated agar was generally higher than native melting temperature except from Riversdale, Scorching Bay and G. secundata populations. 

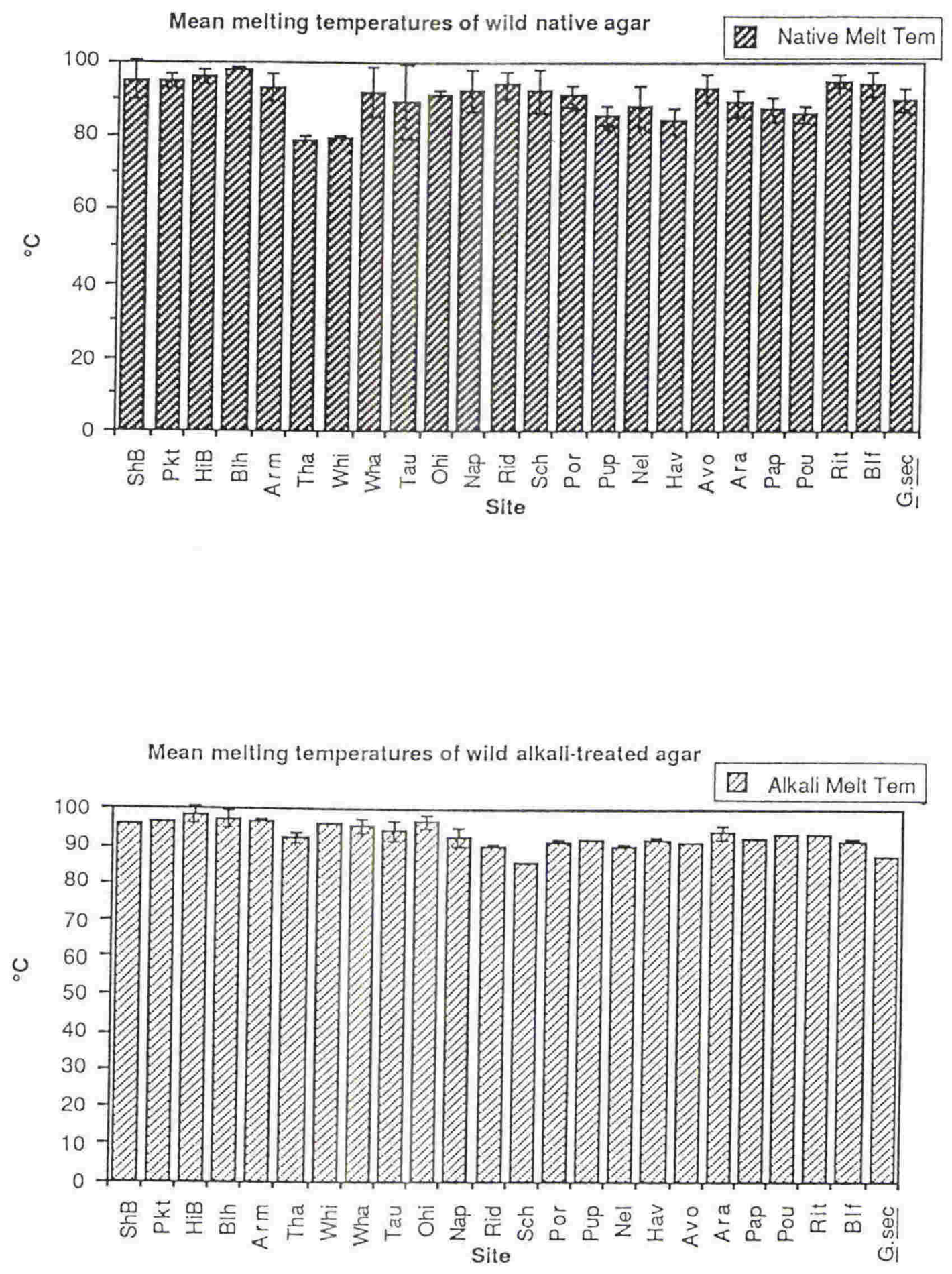

Figure 4.6. Mean 'melting temperatures of the agar of Gracilaria sordida and Gracilaria secundata tetrasporophytes from different sites. Vertical bars represent $95 \%$ confidence limits (mean $\pm 2 \times \mathrm{SD}$ ) 


\subsubsection{Bag-culture growth rate.}

From 18 of the $G$. sordida collecting sites, sufficient material was obtained to culture samples in $30 \mathrm{l}$ plastic bags with PES medium. The mean relative growth rates $\left(\% \cdot \mathrm{d}^{-1}\right)$ for each of these samples during 2 months in culture are given in Figure 4.7. The fastest relative growth rate $\left(6.2 \% . \mathrm{d}^{-1}\right)$ was obtained from the Aramoana population. G. sordida from the Manukau Harbour sites, and from Riversdale, Avon-Heathcote Estuary and Aramoana adapted very well to the culture environment (RGR $4-6 \%$. $\mathrm{d}^{-1}$ ) while Gracilaria from the Pounawea population had the lowest growth rate probably because of heavy fouling by epiphytes. 
Mean relative growth rate of Gracilaria sordida in plastic bag culture

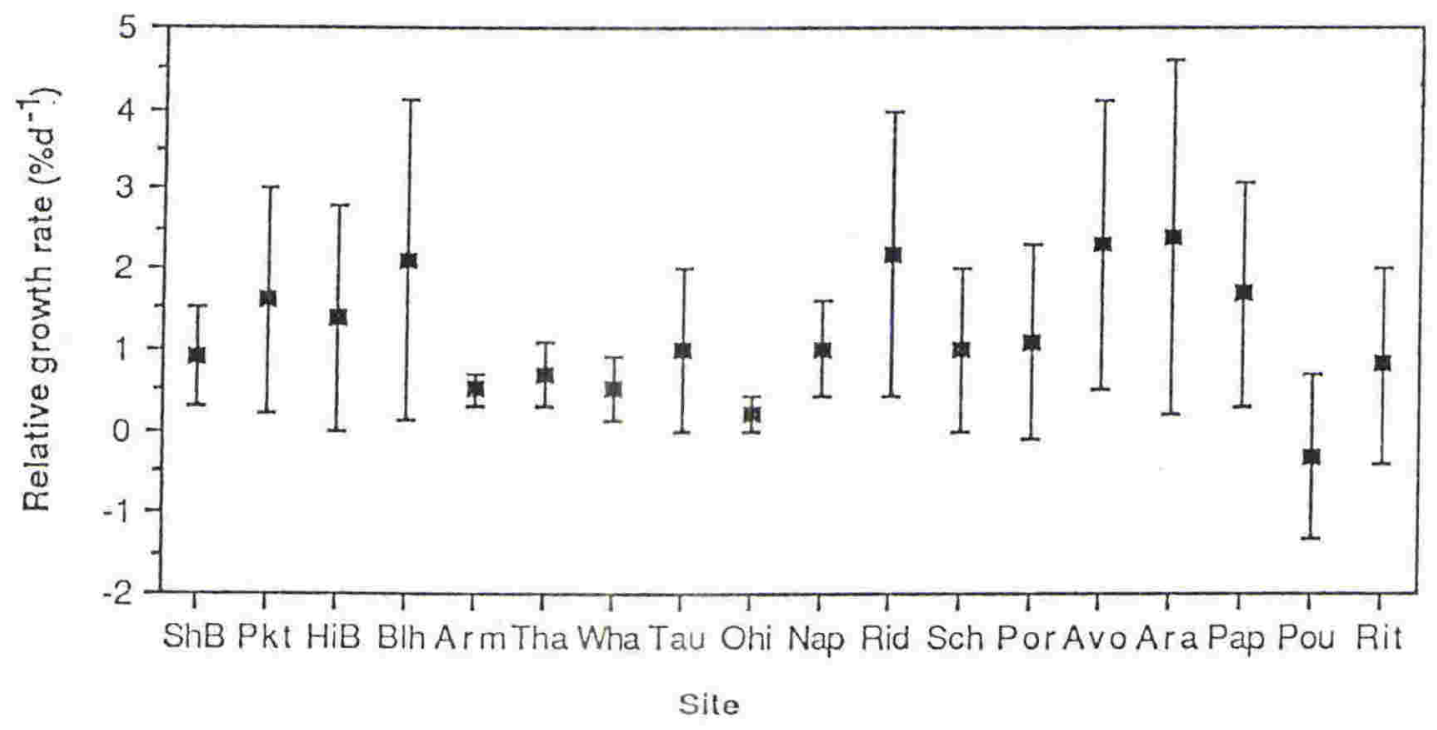

Figure 4.7. Mean relative growth rate $\left(\%, \mathrm{~d}^{-1}\right)$ of tetrasporophyte plants of Gracilaria sordida in plastic bag culture. Vertical bars represent $95 \%$ confidence limits: (mean $\pm 2 \times \mathrm{SD}$ ). 


\subsection{DISCUSSION.}

Variation in agar yield and gel strength has been reported within Gracilaria species from many parts of the world. A summary of agar yields and gel strengths obtained from Gracilaria species from different countries is shown in Table 4.2.

Table 4.2. Agar yield (\% dry weight) and gel strength $\left(\mathrm{g} . \mathrm{cm}^{-2}\right)$ of Gracilaria. (Unless noted otherwise all agar extracts are from untreated seaweed and gel strengths are from $1.5 \%$ gels)

\begin{tabular}{|c|c|c|c|c|}
\hline Species & *Location & Yield & Gel strength & Ref \\
\hline G. chorda & Canada & 15.7 & $25.4(129 * *)$ & 1 \\
\hline G. verrucosa & Canada & 13.5 & $138(110 * *)$ & 1 \\
\hline G. pseudoverrucosa & Canada & 11.3 & $12.7(63.7 * *)$ & 1 \\
\hline G. cylindrica & USA & $24-40$ & $32-605$ & 2 \\
\hline G. cylindrica & USA & $24-42$ & $32-900$ & 3 \\
\hline G. bursapastoris & USA & $6-32$ & 181 & 4 \\
\hline G. bursapastoris & USA & 23 & 351 & 5 \\
\hline G. abbottiana & USA & 15 & 17 & 6 \\
\hline G. tikvahiae & USA & $18-40$ & $25-110$ & 7 \\
\hline G. tikvahiae & USA & $10-23$ & - & 8 \\
\hline G. tikvahiae & USA & $34-43$ & - & 9 \\
\hline G. verrucosa(St.G.16) & USA & $16-23$ & $374-1074$ & 10 \\
\hline G. sjoestedtii & USA & 16 & $(1,100 * *)$ & 11 \\
\hline G. arcuata & Micronesia & $27-31$ & $<100$ & 12 \\
\hline G.edulis & Micronesia & $20-71$ & $78-100$ & 12 \\
\hline G. lichenoides & Micronesia & $28-36$ & $240-340$ & 12 \\
\hline G. salicornia & Micronesia & $16-23$ & $88-100$ & 12 \\
\hline
\end{tabular}




\begin{tabular}{|c|c|c|c|c|}
\hline G. sp. & Micronesia & 32 & 110 & 12 \\
\hline G. blodgettii & Taiwan & 28 & 100 & 12 \\
\hline G. edulis & Taiwan & 31 & 130 & 12 \\
\hline G. coronopifolia & Taiwan & $18-31$ & $110-195$ & 12 \\
\hline G. verrucosa & Taiwan & $21-24$ & $145-170$ & 12 \\
\hline G. tenuistipitata & China & 13.2 & - & 13 \\
\hline G. eucheumoides & China & 12.5 & - & 13 \\
\hline G. blodgettii & China & 6.1 & - & 13 \\
\hline G. verrucosa & Israel & 68 & - & 14 \\
\hline G. cf.verrucosa & Israel & $15-17$ & 204 & 15 \\
\hline G. sp. & Israel & $7.5-13$ & $100-125$ & 16 \\
\hline G. cf.conferta & Israel & $17-25$ & $59-249$ & 16 \\
\hline G. corticata & India & $14-25$ & $17-27$ & 18 \\
\hline G. edulis & India & $31-40$ & $(31-119 * *)$ & 19 \\
\hline G. cylindrica*** & Thailand & $28-37$ & 265 & 20 \\
\hline G. $s p$ & Thailand & $21-51$ & $\left(110-340^{* *}\right)$ & 21 \\
\hline G. edulis & Brazil & $28-37$ & $148-182$ & 23 \\
\hline G. verrucosa & Brazil & $48-54$ & $291-345$ & 23 \\
\hline G. sjoestedtii & Brazil & $47-49$ & $285-321$ & 23 \\
\hline G. verrucosa & Chile & $17-26$ & $113-692$ & 24 \\
\hline G. dentata & Ghana & $8-30$ & - & 25 \\
\hline G. secundata & $\mathrm{NZ}$ & $21-37$ & $<25$ & 26 \\
\hline G. secundata & NZ & 28 & - & 27 \\
\hline G. sordida & NZ & $18-28$ & $6-219 * * * *$ & 28 \\
\hline G. sordida & $\mathrm{NZ}$ & $27-36$ & - & 29 \\
\hline G. sordida & $\mathrm{NZ}$ & $18-36$ & $25-160 * * * *$ & 26 \\
\hline G. sordida & $\mathrm{NZ}$ & $8-16$ & $61-211$ & 30 \\
\hline G. sordida & $\mathrm{NZ}$ & $15-25$ & $180-420$ & 31 \\
\hline G. sordida & NZ & $10-28$ & $20-330$ & 32 \\
\hline
\end{tabular}




\footnotetext{
* Location of weed origin

** Figures in parenthesis are values obtained from alkali-treated seaweeds.

***now classified as Polycavernosa changii.

$* * * * 1 \%$ gel concentration.
}

\section{References.}

1. Whyte and Englar, 1980. 2. Doty and Santos, 1983. 3. Doty and Santos, 1983. 4. Hoyle, 1978. 5. Santos, 1980. 6. Santos and Doty, 1983. 7. Bird et al., 1981. 8. Penniman and Mathieson, 1987. 9. Asare, 1980. 10. Daugherty and Bird, 1988. 11. Hansen, 1984. 12. Nelson et al., 1983. 13. Lahaye et al., 1986. 14. Friedlander et al., 1981. 15. Friedlander and Lipkin, 1982. 16. Friedlander and Zelikovitch, 1984. 17. Friedlander et al., 1987. 18. Oza, 1978. 19. Thomas and Krishnamurthy, 1982. 20. Santos, 1987. 21. Tam and Edwards, 1982. 22. Durairatnam, 1987. 23. Durairatnam and Santos, 1981. 24. Kim and Henriquez, 1978. 25. John and Asare, 1975. 26. Miller and Furneaux, 1987. 27. Brasch et al., 1983. 28. Luxton, 1977. 29. Lignell and Pedersen, 1987. 30. Christeller and Laing, 1989. 31. Pickering, 1990. 32. Intasuwan, this study.

The wide variations in yield and gel strength of agar extracted from G. sordida are similar to those reported for species collected from other natural habitats as shown in Table 4.2.

The native agar yield obtained from wild-harvested populations of $G$. sordida from 23 sites widely distributed around New Zealand ranged from $16 \%$ to $31 \%$ (dry weight) (Mean $=23.5 \% \pm 10.6$ ). These values are similar to those obtained from $G$. sordida from 10 sites by Miller and Furneaux (1987). Agar yields from Manukau Harbour populations (four sites) were $16-23 \%$. This is higher than the value for G. sordida from the same locality reported by Christeller and Laing (1989) (8 - $16 \%$ ) which might result from different extraction 
method and seasonal variation. After alkali pretreatment, agar yields generally decreased, the only exceptions being the samples from Shelly Beach, Riversdale and Porirua Harbour.

Samples from Kaipara Harbour, Manukau Harbour and Aramoana gave native agar gel strengths good enough for food grade agar grade 2 (Japanese standard) (>200 g.cm ${ }^{-2}$ ). Samples from cultured weed generally produced a higher gel strength than that from wild-harvested samples. These results are similar to those of Bird et al. (1981) for G. tikvahiae. The higher gel strength of G. sordida in bag culture is probably due to higher water temperatures and lower light intensity. Bird (1988) and Daugherty and Bird (1988) reported that in both controlled culture and green-house cultivation studies, higher water temperatures led to significantly higher gel strengths in agars.

For nearly all sites, alkali pretreatment led to a large increase in gel strength. The agar samples from Hillsborough Bay, Whitianga, Whangamata Harbour, Tauranga Harbour and Riversdale populations after alkali-pretreatment gave highest gel strengths $\left(>500 \mathrm{~g} . \mathrm{cm}^{-2}\right)$ and were comparable to that of commercial bacteriological grade agar ( $\left.>400-600 \mathrm{~g} . \mathrm{cm}^{-2}\right)$. Three commercial agars tested at $1.5 \%$ concentration for comparison gave gel strengths of $541 \mathrm{~g} . \mathrm{cm}^{-2}$ (Coast PTC agar), $587.5 \mathrm{~g} . \mathrm{cm}^{-2}$ (Davis gelatine agar)and $523.7 \mathrm{~g} . \mathrm{cm}^{-2}$ (Difco Bacto-agar). On average, the agar of $G$ sordida had higher values of gel strength than that of G. secundata. G. sordida from Thames, and G. secundata, responded only slightly to alkali treatment and had the least increase in gel strength compared to the native agar.

Both the gelling and melting temperatures of native agar of $G$. sordida showed a wide range of variation (from $39^{\circ} \mathrm{C}$ to $47^{\circ} \mathrm{C}$ and from $79^{\circ} \mathrm{C}$ to $98^{\circ} \mathrm{C}$, respectively). The extraction of agar using alkali treatment generally gave no change or a slight decrease in gelling temperature but a slight increase in the melting temperature.

Agar gelling temperatures were higher than those reported by Christeller and Laing (1989). There was a positive correlation between melting temperature and gel strength. Guisely (1970) and Cote and Hanisak (1986) reported that high methoxyl content in agar contributed to high melting point. Miller and Furneaux (1987) reported that G. sordida with 
a highly methoxylated agar was found in populations from Manukau Harbour, Avon-Heathcote Estuary and Riverton Estuary. These observations are in agreement with the melting temperatures found in this study for the same populations $\left(>92^{\circ} \mathrm{C}\right)$. This correlation indicates a high molecular weight and hence large size of the agar polymers of G. sordida (Furneaux, pers comm.). Differences in molecular weight (polymer length) is the physical basis for reported variation in the gelling properties of agar extracts from plants of different sources or of the same species grown in different seasons (Whyte et al., 1981; Miller and Furneaux, 1987). A longer polymer may be more capable of linking with others to form a gel matrix, giving a stronger gel and a higher melting point than that formed by shorter polymers (Bird et al., 1981). The melting temperature of Gracilaria species can vary between $60^{\circ} \mathrm{C}$ and $98^{\circ} \mathrm{C}$ and is a function of gel concentration, molecular weight, and degree of methylation (Rees, 1969).

\subsection{CONCLUSIONS.}

There was significant variation in agar yield and gel strength of G. sordida tetrasporophytes among locations (sites). A good gel-strength agar can be obtained from $G$. sordida samples from some of the sites sampled, such as Kaipara Harbour, Manukau Harbour and Aramoana, and after alkali-pretreatment these samples produced gels of acceptable commercial bacteriological grade gel strength. G. sordida also seemed adaptable to culture conditions and gave higher agar quality than wild-harvested weeds. G. sordida from the most promising sites is worthy of trials with respect to mariculture for both agar production and for abalone fodder. 


\section{CHAPTER 5}

\section{ISOZYME VARIATION IN \\ GRACILARIA SORDIDA \\ IN NEW ZEALAND}

\subsection{INTRODUCTION.}

Gracilaria is probably the most promising agar-bearing seaweed in terms of economic benefits derived from mariculture. However, there are still fundamental problems in the taxonomy (Nelson, 1987). Recognition of species within this genus has been complicated and confusing because of the high degree of morphological and anatomical variation exhibited within species. Species limits are also ill-defined and the genus is in need of major revision (Fredericq and Norris, 1985).

The traditional criteria for identifying Gracilaria species are:

1. Vegetative morphology and anatomy such as branching pattern, colour, nature of cortex and medulla.

2. Reproductive anatomy such as shape of cystocarp, gonimoblast structure, a presence or absence of absorbing filaments and spermatangial morphology.

Vegetative morphological criteria have limitations in Gracilaria identification and have been only marginally helpful to taxonomists due to phenotypic plasticity within the species (Reading and Schneider, 1986; Bird and Rice, 1990). Within a species, or even a single thallus, vegetative anatomy varies significantly with age of tissue (May, 1948) or the way a sample has been prepared for examination (Oliveira, 1984).

For reproductive anatomical criteria, some features that have received renewed recognition or emphasis include:

- spermatangial structure (Nelson, 1987; Bird et al. 1986; Fredricq and Hommersand, 1989; Yamamoto, 1978). 
- shape and persistence of the fusion cell (Fredericq and Norris, 1985).

- morphology of the tubular nutritive cells (Krishnamurthy, 1988).

- pericarp structure (Zhang and Xia, 1984).

These structures may be variable within species and ambiguity sometimes occurs (Reading and Schneider, 1986). Vegetative and reproductive anatomical criteria should be used in combination with other features in making taxonomic decisions.

Recently, new approaches to classifying Gracilaria species have been developed. These techniques are:

1) Chromosome number determination (Bird et al., 1982; McLachlan et al., 1977).

2) Characterization of cell-wall polysaccharides (Bird et al., 1987; Craigie et al., 1977).

3) Hybridization (Bird and McLachlan, 1982; Bird et al., 1982).

4) Isozyme analysis and DNA sequencing using electrophoretic techniques (Carroll, 1988: Penniman et al., 1985).

Electrophoretic techniques have contributed a great deal to solving taxonomic problems. All electrophoretic methods have proved useful to varying degrees in characterizing specific organisms. In particular, gel electrophoresis has been extensively used because it has good resolving power.

Starch-gel electrophoretic evaluations of genetic variability have been used extensively to study animal and vascular plant species. In contrast, there has been only a limited application of isozyme techniques to seaweed populations (Cheney, 1985). Isozymes have been detected in some algal species such as blue-green, green, euglenoid, diatom, brown and red algae, but there is still a total of only about 10 algal genera for which information on protein structure and/or variability has been reported (Murphy and Guillard, 1976; Cheney and Babbel, 1978; Grant and Proctor, 1980; Blair et al., 1982; Gallagher, 1980; Soudek and Robinson, 1983; Innes and Yarish, 1984; Fujio et al., 1985; Lindstrom and South, 1989). Because of the relatively small number of electrophoretic population studies on algae and 
also because of some technical difficulties, such as the presence of polyphenols in brown algae which bind strongly to protein and make the enzyme extraction difficult (Rice and Crowden, 1987), phycologists have tended to use traditional approaches to systematic and ecological research (Cheney, 1985).

Studies of the electrophoretic variation of Gracilaria isozymes have not been reported, except by Penniman et al., (1985), who examined Gracilaria tikvahiae for the presence of certain isozymes.

The primary objective of this study was to examine isozyme loci of Gracilaria sordida populations from a wide range of localities in New Zealand and to estimate the degree of genetic differentiation between populations of this species, and the amount of genetic variability within selected populations.

\subsection{MATERIALS AND METHODS.}

\subsubsection{Sample collection, storage and preparation}

G. sordida samples for electrophoretic analysis were collected at 18 locations throughout New Zealand. Sampling locations and sample site names are shown in Table 5.1 (see also Figure 4.1. in Chapter 4). 
Table 5.1. Sampling locations

Site name

Location

1. Shelly Beach

2. Puketutu Island

3. Hillsborough Bay

4. Blockhouse Bay

5. *Armour Bay

6. Thames

7. Whitianga Harbour

8. Whangamata Harbour

9. Tuaranga Harbour

10. Ohiwa Harbour

11. Inner Harbour

12. Riversdale

13. Pauatahanui Inlet

14. Scorching Bay

15. Avon-Heathcote Estuary

16. Aramoana

17. Papanui Inlet

18. Riverton Harbour
Kaipara Harbour

Manukau Harbour

Manukau Harbour

Manukau Harbour

Manukau Harbour

Whitianga

Whangamata

Mount Maunganui

Kutarere

Napier

Whareama river

Porirua Harbour

Wellington Harbour

Christchurch

Otago Harbour

Otago peninsula

Invercargill

\footnotetext{
*Data from the Armour Bay population were later excluded when using the Biosys programme to analyse the genetic variations of these populations, because one isozyme was missing.
} 
Samples were collected at low tide and were placed in plastic bags with moist paper towelling. The bags were kept cool on cold packs or ice in polyurethane boxes until they were used, usually within one week following sampling.

Seaweed samples were examined and plants separated into different sexes using a stereomicroscope. Plants were washed thoroughly in seawater and then rinsed in tap water. All epiphytes and any other foreign material were removed using cotton buds and forceps.

Approximately $1 \mathrm{~g}$ wet weight fresh thallus of each individual was ground under liquid nitrogen with a mortar and pestle and transferred to a $1 \mathrm{ml}$ Eppendorf tube, weighed and mixed 1:1 w/v with extraction buffer (Table 5.2).

The extracted sample was then centrifuged under refrigeration at $13,000 \mathrm{rpm}$ at $13238 \mathrm{x}$ $\mathrm{g}$ for 3 minutes. The supernatant was drawn off into an AA tube for use in starch-gel electrophoresis. The sample was frozen at $-80^{\circ} \mathrm{C}$ and was later used for electrophoresis several times, by chipping out just enough of the frozen sample for each use. Samples and gels were kept chilled throughout extraction and electrophoresis.

From selected populations, cleaned plants additional to those used for extraction were cultured in $30 \mathrm{l}$ plastic bags for two months (see Chapter 4. Section 4.2.2 for details). After harvesting and removing epiphytes, the cultured seaweed samples were extracted for protein, using the above procedure, for electrophoretic analysis so that their isozyme patterns could be compared with those of the wild samples.

\subsubsection{Electrophoretic methods}

The electrophoresis apparatus used is illustrated in Figure 5.1. It consists of an electrical power source, the molded gel and two electrode chambers (trays) containing a buffered electrode solution (Table 5.2). The gel serves as a bridge between the electrode chambers. The electrical current serves to set up a charged field in the gel in which the protein molecules migrate and separate. Each electrode chamber contains a platinum electrode (20 gauge platinum wire) attached to a banana plug set in one end of the chamber. 
About $300 \mathrm{ml}$ of electrode buffer is placed in each chamber for an electrophoretic run. The apparatus is cooled, to prevent heat degradation of the proteins, by placing an ice tray on top of the gel. 

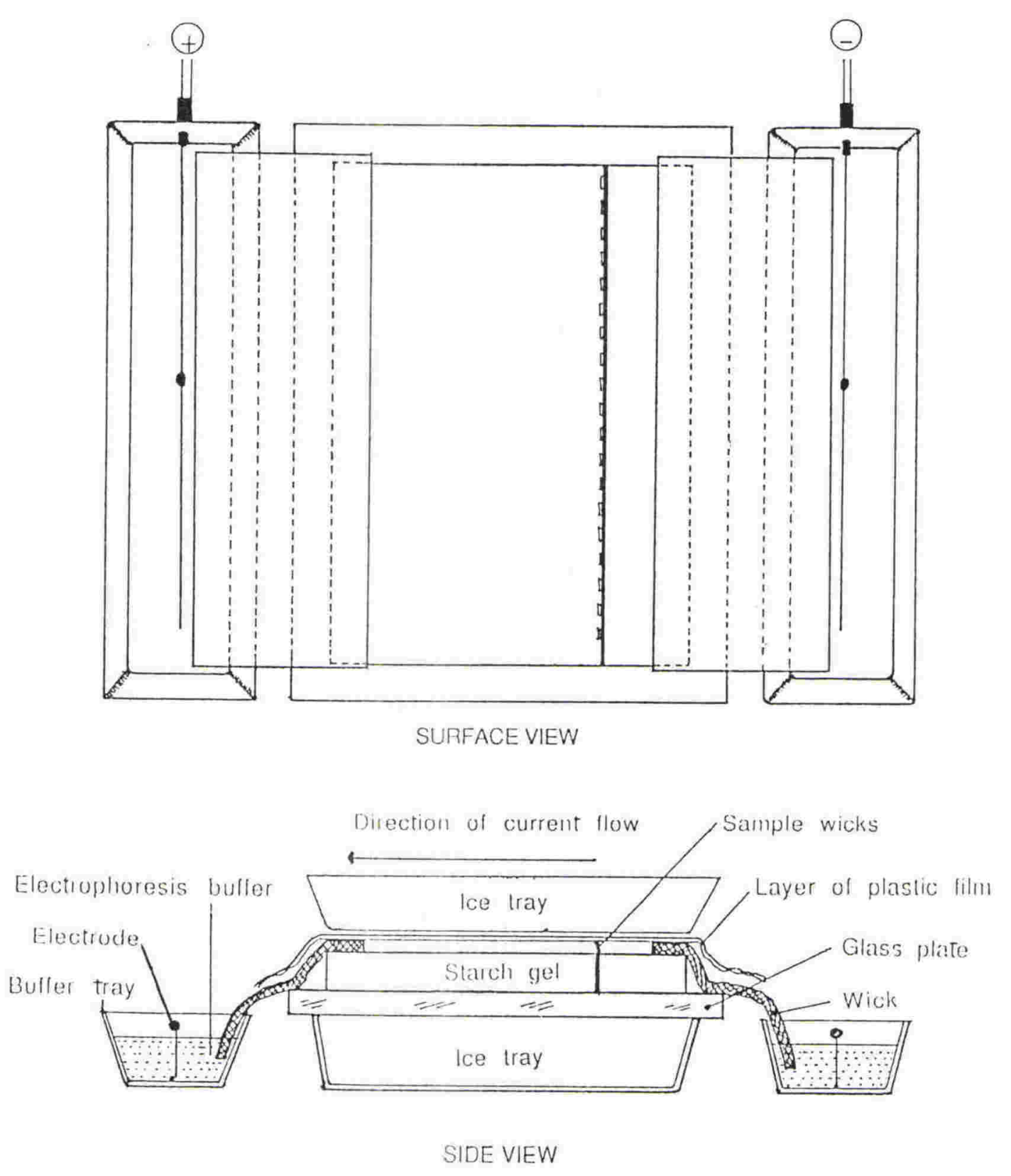

Figure 5.1. Diagram of electrophoretic apparatus. 
Starch gels were made by heating a $14 \%$ solution of starch (Sigma no.S-0451 lot no.108F-0059), (35 g of starch in $250 \mathrm{ml}$ of gel buffer) and degassing it with the aid of a water pump. The gels were poured into a $165 \times 235 \times 5 \mathrm{~mm}$ horizontal mold and allowed to set at room temperature. They were covered with thin plastic film (Gladwrap) and cooled at $4^{\circ} \mathrm{C}$ overnight.

Next morning the gel was unwrapped and wicks of filter paper $(2 \times 6 \mathrm{~mm}$, Whatman no.3) were soaked in the supernatant of individual extract samples and placed vertically in a slot cut across the gel. A single gel held 50 - 60 samples. Cochineal red, a food colour, was used as a tracking dye.

After loading, the gel was placed in contact with the electrode buffer solution. Sponge wicks (Chux cloth) formed a bridge between the gel ends and the electrode buffer solution in the electrode trays. The gel was covered with Gladwrap plastic film, an ice-pack was placed on the gel, and a constant voltage the strength of which, depended on the buffer (see Table 5.2) was applied across the gel. Once the food colour tracking dye had migrated $5 \mathrm{~mm}$ (20 min) the sample wicks were removed, the gel covered with plastic wrap again, the ice-pack replaced on top, and electrophoresis continued.

When the red tracking dye had migrated $4-5 \mathrm{~cm}$ the gel was removed and cut horizontally into 5 - 6 slices, ( $1 \mathrm{~mm}$ in thickness) each of which was stained for a specific enzyme. The staining mixture contains the substrate on which the enzymes acts, forming a coloured product. Thus a coloured band forms only when the enzyme is present. Alternative forms (alleles) of the same enzyme move different distances from the origin, depending on their electric charge, shape and size, the current applied and the $\mathrm{pH}$ of the gel and buffer solutions, producing bands corresponding to individual genotypes. In setting up the system and sorting out which enzymes and buffer to use, selected samples were tested with eight buffer systems (Table 5.2) for 31 different protein or enzyme stains (Table 5.3). Stains and stain buffers were as described by Allendorf et al. (1977), Shaw and Prasad (1970) and Cheney (1985) and are listed in Appendix 6. 
After staining for individual enzymes the gels were photographed and fixed in methanol : acetic acid : distilled water $(5: 1: 5 \mathrm{v} / \mathrm{v})$. Gels required for reference or for rechecking were sealed in plastic bags and kept in a refrigerator. 
Table 5.2. Buffer systems used in starch-gel electrophoresis.

\begin{tabular}{|c|c|c|c|c|}
\hline Buffer & Composition & $\mathrm{pH}$ & $\begin{array}{l}\text { Running } \\
\text { condition }\end{array}$ & Ref \\
\hline \multicolumn{5}{|c|}{ Extractlon buffer } \\
\hline Tris-HCl-mercapto & $0.1 \mathrm{M}$ Tris- $\mathrm{HCl}, \mathrm{pH} 7.0$ & & & a \\
\hline \multirow[t]{2}{*}{ ethanol solution } & $0.02 \%$ mercaptoethanol & & & \\
\hline & $1 \%$ PVP or PVPP & & & \\
\hline \multicolumn{5}{|c|}{ Gel and electrode buffers* } \\
\hline 1. Amine citrate & $0.01 \mathrm{M}$ citric acid & 6 & $3 \mathrm{~h}, 150 \mathrm{~V}$ & $b$ \\
\hline$(\mathrm{AC})$ & $0.04 \mathrm{M}$ citric acid & 6.1 & & \\
\hline 2. Phosphate & $0.069 \mathrm{M} \mathrm{KH} 2 \mathrm{PO} 4$ NADP & 6.7 & & \\
\hline$(\mathrm{PH})$ & $0.138 \mathrm{M} \mathrm{KH} 2 \mathrm{PO} 4$ & 7 & $3 \mathrm{~h}, 150 \mathrm{~V}$ & c \\
\hline 3. Poulik & $0.067 \mathrm{M}$ Tris $-0.005 \mathrm{M}$ citric acid & 8.7 & & \\
\hline$(\mathrm{PK})$ & $0.30 \mathrm{M}$ boric acid $\cdot 0.06 \mathrm{M} \mathrm{NaOH}$ & 8.7 & $4 \mathrm{~h}, 300 \mathrm{~V}$ & c \\
\hline 4. Ridgeway & $0.03 \mathrm{M}$ Tris $-0.005 \mathrm{M}$ citric acid & 8.5 & & \\
\hline$(\mathrm{AW})$ & $0.30 \mathrm{M}$ boric acid - $0.06 \mathrm{M} \mathrm{LiOH}$ & 8.1 & $4 \mathrm{~h}, 300 \mathrm{~V}$ & $\mathrm{~b}$ \\
\hline 5. Tris-citrate-1 & $0.009 \mathrm{M}$ Tris $-0.003 \mathrm{M}$ citric acid & 7 & & \\
\hline$(\mathrm{TC}-1)$ & $0.13 \mathrm{M}$ Tris $-0.43 \mathrm{M}$ citric acid & 7 & $3 \mathrm{~h}, 150 \mathrm{~V}$ & $\mathrm{~b}$ \\
\hline 6. Tris-citric-3 & $0.023 \mathrm{M}$ Tris $-0.005 \mathrm{M}$ citric acid & 8 & & \\
\hline$(\mathrm{TC}-3)$ & $0.678 \mathrm{M}$ Tris $-0.157 \mathrm{M}$ citric acid & 8 & $3 \mathrm{~h}, 170 \mathrm{~V}$ & c \\
\hline \multirow{3}{*}{$\begin{array}{l}\text { 7. Tris-EDTA-borate } \\
\text { (TEB) }\end{array}$} & $0.045 \mathrm{M}$ Tris $-0.001 \mathrm{M}$ EDTA & & & \\
\hline & $0.025 \mathrm{M}$ boric acid & 8.6 & & \\
\hline & $0.180 \mathrm{M}$ Tris - $0.005 \mathrm{M}$ EDTA $-0.1 \mathrm{M}$ boric acid & 8.6 & $4 \mathrm{~h}, 400 \mathrm{~V}$ & a \\
\hline 8. Tris-glycine & $0.009 \mathrm{M}$ Tris - $0.025 \mathrm{M}$ glycine & 8.3 & & \\
\hline$(\mathrm{TG})$ & $0.304 \mathrm{M}$ boric acid $-0.1 \mathrm{M} \mathrm{Na} \mathrm{OH}$ & 8.6 & $4 \mathrm{~h}, 400 \mathrm{~V}$ & a \\
\hline
\end{tabular}

a. Cheney (1985)

b. Allendorf et al.(1977)

c. Selander et al.(1971)

Note: ${ }^{*}$ Gel buffer is mentioned first and electrode buffer mentioned second. 
Table 5.3. Enzymes and proteins assayed in all specimens.

\begin{tabular}{lll} 
Enzyme & Abbreviation & E.C.Number \\
\hline Acid phosphatase & ACP & 3.1 .3 .2 \\
Aconitase & ACON & 4.2 .1 .3 \\
Alcohol dehydrogenase & ADH & 1.1 .1 .1 \\
Aldolase & ALD & 4.1 .2 .13 \\
B-galactosidase & B-GAL & 3.1 .123 \\
B-glucosidase & B-GLU & 3.2 .1 .21$. \\
Catalase & CAT & 1.11 .1 .6 \\
Esterase & EST & 3.1 .1 .1 \\
Fructose-1,6-diphosphase & FDP & 3.1 .3 .11 \\
General protein & GP & non-enz pro \\
Glucose-6-phosphate dehydrogenase & GD(G6PDH) & 1.1 .1 .49 \\
Glucosephosphate isomerase & GPI(PGI) & 5.3 .1 .9 \\
Glutamate dehydrogenase & GLUD(GDH) & 1.4 .1 .3 \\
Glutamate oxaloacetate transaminase & GOT(AAT) & 2.6 .1 .1 \\
Glyceraldehyde phosphate dehydrogenase & GAPDH & 1.2 .1 .12 \\
Glycerol dehydrogenase & GLYDH & 1.1 .1 .6 \\
Glycerol-3-phosphate dehydrogenase & GPD(G3P) & 1.1 .1 .8 \\
Isocitrate dehydrogenase & ICD(IDH) & 1.1 .1 .42$. \\
Lactate dehydrogenase & LDH & 1.1 .1 .27 \\
Leucine aminopepidase & LAP & 3.4 .11 \\
Malate dehydrogenase & MDH & 1.1 .1 .37 \\
Mannose phosphate isomerase & MPI(PMI) & 5.3 .1 .8 \\
Peptidase & PEP & 3.4 .11 \\
Phosphogluconate dehydrogenase & PGD(6PGDH) & 1.1 .1 .44 \\
Peroxidase & POX & 1.11 .1 .7 \\
Succinate dehydrogenase & SUCDH & \\
Shikimate dehydrogenase & SKDH & \\
Sorbitol dehydrogenase & SORDH(SDH) & 1.1 .1 .14 \\
Superoxide dismutase & SOD & 1.15 .1 .1 \\
Triose phosphate isomerase & TPI & 5.3 .1 .1 \\
\hline
\end{tabular}
E.C. Number = a standardized set of systematic names and numbers for enzymes by the
Enzyme Commission (1973). 


\subsubsection{Analysis of isozyme variation.}

Interpretation of stained enzyme banding patterns on gels and identification of monomeric vs dimeric proteins and homozygous vs heterozygous individuals followed general practice in electrophoretic studies (Shields et al., 1983). The system of enzyme nomenclature used throughout this study is that of Richardson et al. (1986). Enzymes are designated by the abbreviation listed in Table 5.3. Homology between alleles was assumed only when they occurred on the same gel slice and were judged to have identical mobilities. In case of doubt the samples were rerun beside alleles of known mobility and reassessed. To faciliate scoring, samples from at least four previously scored individuals were included in each gel run. Enzyme nomenclature followed that of the Enzyme Nomenclature Recommendation (1978) as adopted by Richardson et al. (1986). Enzymes or proteins are referred to by abbreviations in upper case letters, for example peptidase is referred to as PEP. Specific gene loci producing the enzymes are denoted by mixed upper and lower case letters namely, an initial upper case letter followed by lower case, followed by a hyphen and numeral to indicate the specific allozyme locus (e.g. Pep-1). Isozymes are numbered sequentially from anode to cathode. Numbers of alleles are also refered to by letters $(A, B$, C) and denoted from anode to cathode.

BIOSYS-1, a Fortran IV computer programme designed to analyse electrophoretically detectable variation was used to:

1) compute allele frequencies and genetic variability measures,

2) test for deviation from Hardy-Weinberg equilibria,

3) perform heterogeneity Chi-square analyses,

4) calculate a variety of similarity and distance coefficients,

5) construct phenograms using cluster analysis, and

6) estimate phylogenies using the Wagner distance procedure (Swofford and Selander, 1981). 


\subsection{RESULTS.}

Because of limitation of both time and the BIOSYS-1 Program, only these electrophoretic data obtained from the tetrasporophyte plants (diploid) are used for calculating genetic variation between populations.

Of the 30 proteins tested in eight buffer systems, 16 enzymes and two general proteins, coding for 20 loci, were resolved from the zymograms (Table 5.4). Not every locus detected was scored because a few did not consistently show up from run to run and so were excluded from analyses (Ald-1, B- Gal-1, Est-1 and Pox-1). Two of the 20 loci (10\%) were polymorphic, namely Gd-1 and Pgm-1. The buffer systems which provided the best overall enzyme resolution were RW, TG and TEB. 
Table 5.4. Allozyme loci detected in screening tests.

Locus

Buffer

Number of alleles

\begin{tabular}{lll} 
Ald-1 & TEB, TG & 1 \\
B-Gal-1 & PK, RW, TEB & 1 \\
Cat-1 & RW, TG & 1 \\
Est-1 & AC, TG & 1 \\
Gp-1 & AC, PK, RW, TC, TEB, TG & 1 \\
Gp-2 & AC, PK, RW, TC, TEB, TG & 1 \\
Gd-1 & AC, PK, RW, PH, TEB, TG & 3 \\
Gapdh-1 & RW, TEB, TG, & 1 \\
Ldh-1 & PK, RW, TEB, TG & 1 \\
Mdh-1 & AC, RW, PK, TC, TEB, TG, & 1 \\
Mpi-1 & AC, RW, TC, TEB, TG & 1 \\
Pep-1 & AC, PH, PK, RW, TEB, TG & 1 \\
Pep-2 & AC, PH, PK, RW, TEB, TG & 1 \\
Pgd-1 & AC, PH, RW, TEB, TG & 1 \\
Pgi-1 & AC, PK, RW, PH, PK, TC, TEB, TG & 2 \\
Pgm-1 & AC, PH, PK, RW, TC, TEB, TG & 1 \\
Pox-1 & AC & 1 \\
\hline & & 1 \\
\hline
\end{tabular}


Allele frequencies for each population sample are given in Table 5.5.

There were no differences in electromorph expression between each population and the sample cultured from it. The Gd locus showed a clear banding pattern, always showed up in all buffer systems tested and was found in all G. sordida populations, but not in $G$. secundata samples, which was used as a genetic "outlyer" and as a negative control for Gd locus. Hence these enzymes could turn out to be diagnostic in distinguishing between these two species, although a range of populations of $G$. secundata would need to be examined to confirm this. 


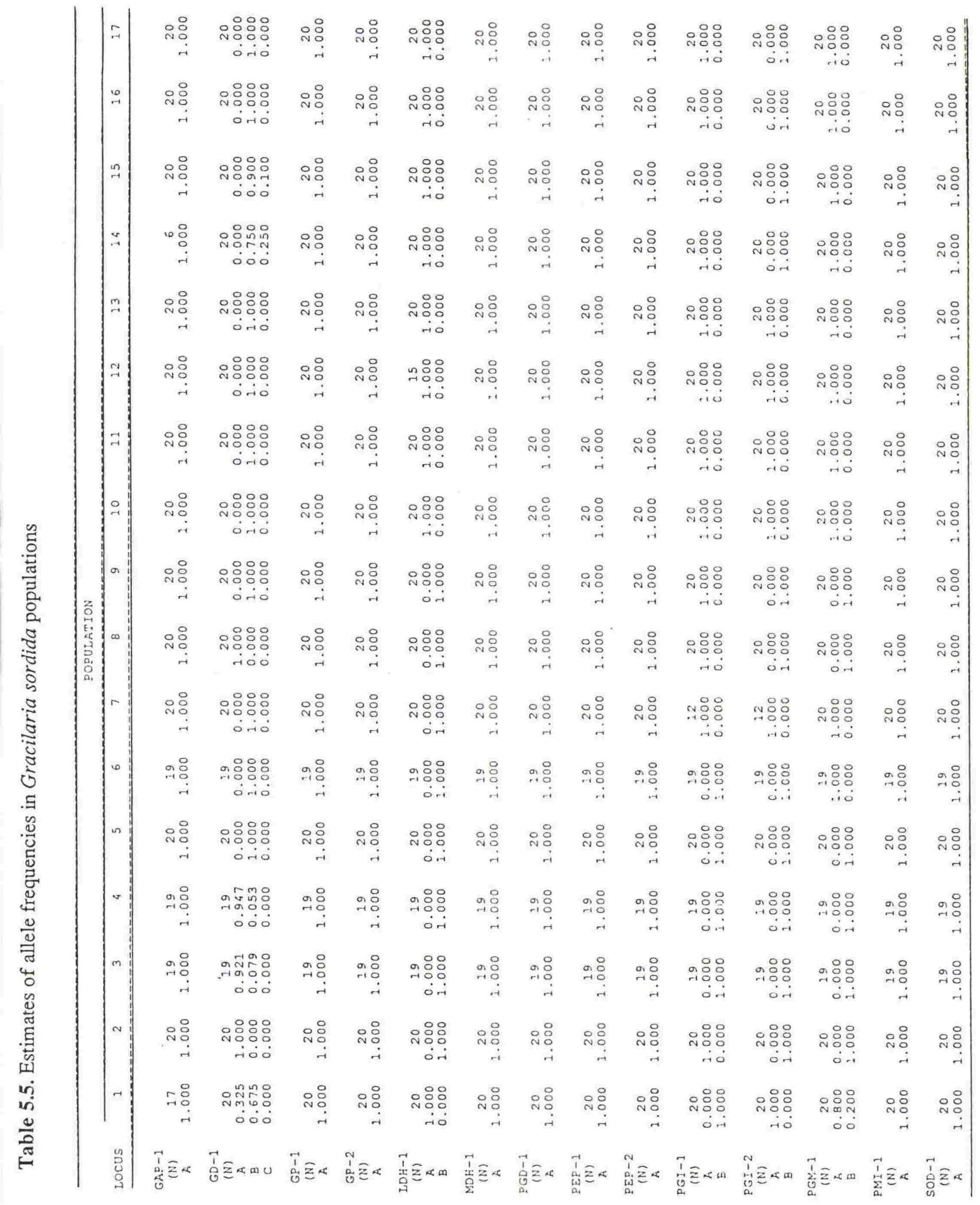




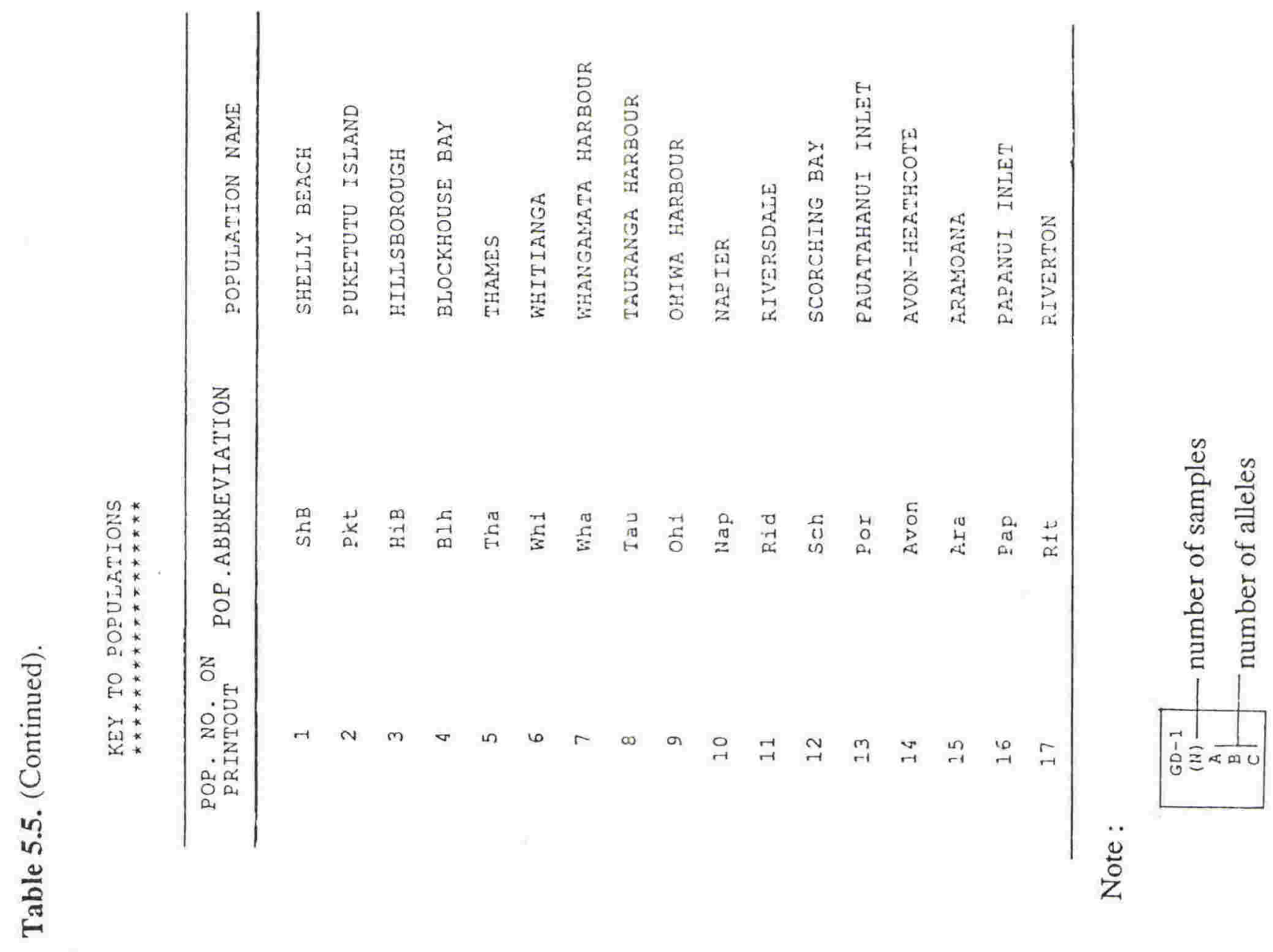


Genetic variation within G. sordida was estimated by polymorphism (P) and heterozygosity $(\mathrm{H})$. Genetic variability measurements for each population are shown in Table 5.6. Allele frequencies at most loci have identical Chi-squared values and do not differ from Hardy-Weinberg expectations except for the Gd-1 and Pgm-1 loci from the Shelly Beach population (Chi-squared values $=9.5$ and 22.4 respectively) and the Gd-1 locus from Hillsborough Bay (Chi-squared value = 11.6), Blockhouse Bay (Chi-squared value $=37.0)$, Avon-Heathcote (Chi-squared value $=21.8)$ and Aramoana (Chi-squared value $=26.0$ ), which differ from the expected Hardy-Weinberg equilibrium. The Shelly Beach population showed the highest percentage of polymorphic loci $(14.3 \%)$. 
Table 5.6. Genetic variability measurements for each population of Gracilaria sordida.

(STANDARD ERRORS IN PARENTHESES)

\begin{tabular}{|c|c|c|c|c|c|c|}
\hline \multirow{2}{*}{\multicolumn{2}{|c|}{ POPULATION }} & \multirow{2}{*}{$\begin{array}{l}\text { EAN SAMPLE } \\
\text { SIZE PER } \\
\text { LOCUS }\end{array}$} & \multirow{2}{*}{$\begin{array}{l}\text { MEAN NO. } \\
\text { OF ALLELES } \\
\text { PER LOCUS }\end{array}$} & \multirow{2}{*}{$\begin{array}{l}\text { PERCENTAGE } \\
\text { OF LOCI } \\
\text { POLYMORPHIC* }\end{array}$} & \multicolumn{2}{|c|}{ MEAN HETEROZYGOSITY } \\
\hline & & & & & $\begin{array}{l}\text { DIRECT- } \\
\text { COUNT }\end{array}$ & $\begin{array}{l}\text { HDYWBG } \\
\text { EXPECTED * }\end{array}$ \\
\hline 1. & SHELLY BEACH & $\begin{array}{l}19.8 \\
(0.2)\end{array}$ & $\begin{array}{l}1.1 \\
(0.1)\end{array}$ & 14.3 & $\begin{array}{l}0.011 \\
(0.011)\end{array}$ & $\begin{array}{l}0.056 \\
(0.038)\end{array}$ \\
\hline 2. & PUKETUTU ISLAND & $\begin{array}{c}20.0 \\
(0.0)\end{array}$ & $\begin{array}{l}1.0 \\
(0.0)\end{array}$ & 0.0 & $\begin{array}{l}0.000 \\
(0.000)\end{array}$ & $\begin{array}{l}0.000 \\
(0.000)\end{array}$ \\
\hline 3. & HILLSBOROUGH & $\begin{array}{c}19.0 \\
\left(\begin{array}{l}0.0 \\
0\end{array}\right)\end{array}$ & $\begin{array}{c}1.1 \\
(0.1)\end{array}$ & 7.1 & $\begin{array}{l}0.004 \\
(0.004)\end{array}$ & $\begin{array}{c}0.011 \\
(0.011)\end{array}$ \\
\hline 4. & BLOCKHOUSE BAY & $\begin{array}{c}19.0 \\
(0.0)\end{array}$ & $\begin{array}{l}1.1 \\
(0.1)\end{array}$ & 7.1 & $\begin{array}{l}0.000 \\
(0.000)\end{array}$ & $\begin{array}{c}0.007 \\
(0.007)\end{array}$ \\
\hline 5. & THAMES & $\left(\begin{array}{c}20.0 \\
(0.0)\end{array}\right.$ & $\begin{array}{l}1.0 \\
(0.0)\end{array}$ & 0.0 & $\begin{array}{l}0.000 \\
(0.000)\end{array}$ & $\begin{array}{l}0.000 \\
(0.000)\end{array}$ \\
\hline 6. & WHITIANGA & $\begin{array}{l}19.0 \\
(0.0)\end{array}$ & $\begin{array}{l}1.0 \\
(0.0)\end{array}$ & 0.0 & $\begin{array}{l}0.000 \\
(0.000)\end{array}$ & $\begin{array}{l}0.000 \\
(0.000)\end{array}$ \\
\hline 7. & WHANGAMATA HARBOUR & $\begin{array}{l}18.9 \\
(0.8)\end{array}$ & $\begin{array}{l}1.0 \\
(0.0)\end{array}$ & 0.0 & $\begin{array}{l}0.000 \\
(0.000)\end{array}$ & $\begin{array}{l}0.000 \\
(0.000)\end{array}$ \\
\hline 8. & TAURANGA HARBOUR & $\left(\begin{array}{c}20.0 \\
(0.0)\end{array}\right.$ & $\begin{array}{l}1.0 \\
(0.0)\end{array}$ & 0.0 & $\begin{array}{l}0.000 \\
(0.000)\end{array}$ & $\begin{array}{l}0.000 \\
(0.000)\end{array}$ \\
\hline 9. & OHIWA HARBOUR & $\left(\begin{array}{l}20.0 \\
(0.0)\end{array}\right.$ & $\begin{array}{l}1.0 \\
(0.0)\end{array}$ & 0.0 & $\begin{array}{l}0.000 \\
(0.000)\end{array}$ & $\begin{array}{l}0.000 \\
(0.000)\end{array}$ \\
\hline 10. & NAP IER & $\begin{array}{l}20.0 \\
(0.0)\end{array}$ & $\begin{array}{l}1.0 \\
(0.0)\end{array}$ & 0.0 & $\begin{array}{l}0.000 \\
(0.000)\end{array}$ & $\begin{array}{l}0.000 \\
(0.000)\end{array}$ \\
\hline 11. & RIVERSDALE & $\begin{array}{c}20.0 \\
(0.0)\end{array}$ & $\begin{array}{l}1.0 \\
(0.0)\end{array}$ & 0.0 & $\begin{array}{c}0.000 \\
(0.000)\end{array}$ & $\begin{array}{c}0.000 \\
(0.000)\end{array}$ \\
\hline 12. & SCORCHING BAY & $\begin{array}{c}19.6 \\
(\quad 0.4)\end{array}$ & $\begin{array}{l}1.0 \\
(0.0)\end{array}$ & 0.0 & $\begin{array}{c}0.000 \\
(0.000)\end{array}$ & $\begin{array}{c}0.000 \\
(0.000)\end{array}$ \\
\hline 13. & PAUATAHANUI INLET & $\begin{array}{c}20.0 \\
(0.0)\end{array}$ & $\begin{array}{l}1.0 \\
(0.0)\end{array}$ & 0.0 & $\begin{array}{c}0.000 \\
(0.000)\end{array}$ & $\begin{array}{c}0.000 \\
(0.000)\end{array}$ \\
\hline 14. & AVON-HEATHCOTE & $\left(\begin{array}{c}19.0 \\
(1.0)\end{array}\right.$ & $\begin{array}{l}1.1 \\
(0.1)\end{array}$ & 7.1 & $\begin{array}{c}0.000 \\
(0.000)\end{array}$ & $\begin{array}{c}0.027 \\
(0.027)\end{array}$ \\
\hline 15. & ARAMOANA & $\begin{array}{l}20.0 \\
(0.0)\end{array}$ & $\begin{array}{c}1.1 \\
(0.1)\end{array}$ & 7.1 & $\begin{array}{c}0.000 \\
(0.000)\end{array}$ & $\begin{array}{c}0.013 \\
(0.013)\end{array}$ \\
\hline 16. & PAPANUI INLET & $\begin{array}{c}20.0 \\
(0.0)\end{array}$ & $\begin{array}{l}1.0 \\
(0.0)\end{array}$ & 0.0 & $\begin{array}{c}0.000 \\
(0.000)\end{array}$ & $\begin{array}{c}0.000 \\
(0.000)\end{array}$ \\
\hline 17. & RIVERTON & $\begin{array}{c}20.0 \\
(0.0)\end{array}$ & $\begin{array}{l}1.0 \\
(0.0)\end{array}$ & 0.0 & $\begin{array}{c}0.000 \\
(0.000)\end{array}$ & $\begin{array}{c}0.000 \\
(0.000)\end{array}$ \\
\hline
\end{tabular}

* A LOCUS IS CONSIDERED POLyMORPHIC IF MORE THAN ONE ALLELE WAS DETECTED

* * UNBIASED ESTIMATE (SEE NEI, 1978) 
Nei's (1978) unbiased genetic similarity (I) and genetic distance (D) were calculated between 17 populations of $G$. sordida for 20 loci and these data are presented in Table 5.7. Genetic similarity (I) is the normalized identity of a gene between two populations, with $\mathrm{D}=$ $-\log _{\mathrm{e}}$ I. Results from this study showed small genetic distance values, which reflected the high degree of protein similarity between all of these populations (D values ranged from 0.00 to 0.432 ). 
The phenogram obtained by cluster analysis, illustrating the distribution of genetic variation between populations of $G$. sordida, is shown in Figure 5.2. Cluster patterns in Figure 5.2. reflect the effects of two key polymorphic loci, Gd-1 and Pgm-1. The electrophoretic relationships of $G$. sordida populations for 20 loci are very close: all genetic distances are small, ranging from 0.00 to 0.432 . The smallest distance $(0.000)$ was obtained between the populations from Blockhouse Bay and Hillsborough Bay, between Napier and Riversdale, between Scorching Bay and Pauatahanui Inlet, and between Papanui Inlet and Riverton. The largest distance (0.432) was obtained between the Blockhouse Bay population and the Napier, Riversdale, Scorching Bay and Pauatahanui Inlet populations.

No strong correlation between the geographic distance and genetic distance was observed. However, the phenogram indicates that $G$. sordida populations from 17 localities in New Zealand could be divided into two groups:

Group 1. includes the populations from Kaipara Harbour, Whangamata Harbour, Napier, Riversdale, Scorching Bay, Pauatahanui Inlet and all populations from the South Island.

Group 2. includes the populations from Manukau Harbour, Tauranga Harbour, Ohiwa Harbour, Thames and Whitianga.

The distribution pattern of genetic variations among the localities of $G$. sordida in the wild populations and cultured populations could be regarded as indicating the degree of genetic isolation. 
.

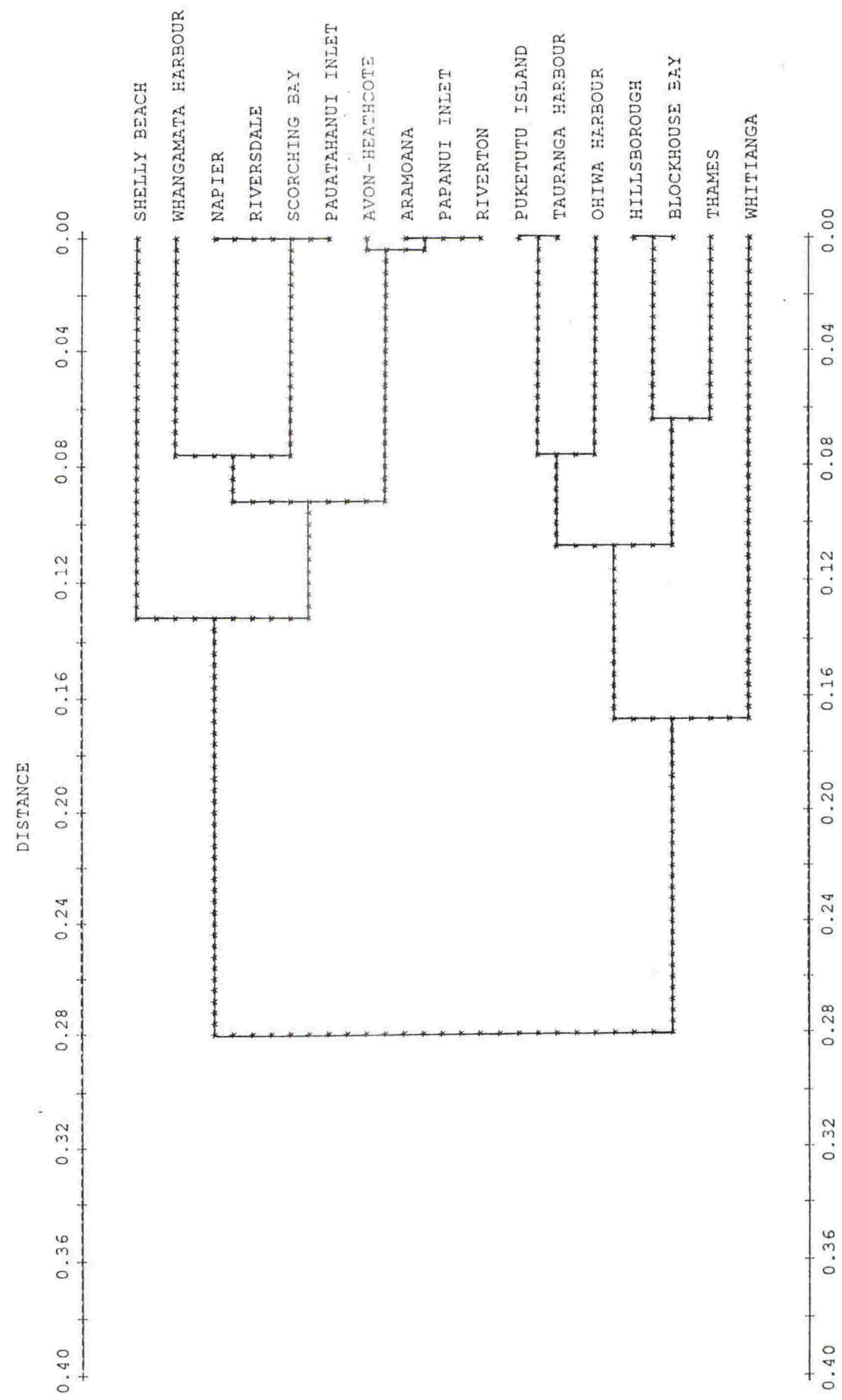




\subsection{DISCUSSION.}

Starch gel electrophoresis was used to measure genetic variation in G. sordida in New Zealand. Of the 30 enzymes tested in eight buffer systems, 16 enzymes and two general proteins produced good staining responses suitable for genetic analysis. The number of enzymes found in this study is similar to the 13 enzymes reported by Penniman et al. (1985) for Gracilaria tikvahiae. The enzyme systems which are found in both $G$. sordida and $G$. tikvahiae are B-GAL, EST, LDH, PEP, PGD, PGI, PGM and SOD. The electrophoretically detectable enzymes of G. sordida and G. tikvahiae (Penniman et al., 1985) are compared in Table 5.8. 
Table 5.8. Comparison of the electrophoretically detectable enzymes of Gracilaria sordida (NZ) and Gracilaria tikvahiae (USA).

Enzyme G. sordida G. tikvahiae

\begin{tabular}{llll}
\hline CAT & - & + \\
ALD & + & - \\
B-GAL & + & + \\
B-GLU & - & + \\
CAT & + & + & + \\
EST & + & - & - \\
FDH & - & + & + \\
GP & + & + \\
GD & + & - \\
GAPDH & + & + \\
GLYDH & - & + & + \\
LDH & + & + \\
MDH & + & + \\
MPI & + & + \\
PEP & + & + \\
PGD & + & + \\
PGI & + & + \\
PGM & + & + \\
POX & + & + \\
SOD & + & + \\
TPI & - & + \\
\hline
\end{tabular}


The electrophoretic results of the present study indicate low genetic variability between populations of $G$. sordida from 17 sites in New Zealand. G. sordida displayed a high proportion of monomorphic loci $(90 \%)$ and a low proportion of polymorphic loci (10\%). The highest heterozygosity estimate for G. sordida was 0.011 (Shelly Beach population; $\mathrm{n}=$ 20 loci). In contrast, Fujio et al. (1985) reported the amount of heterozygosity in Porphyra yezoensis was $50 \%$. Genetic distances between $G$. sordida populations were small $(\mathrm{D}=$ $0.00-0.432)$.

There are several hypotheses that could explain the characteristically small genetic variation within $G$. sordida populations:

1) Variation within the regulatory enzymes of G. sordida populations is low;

2) Nei's (1978) assumptions are not met. Nei suggested that the accuracy of statistical calculations of population genetics depends on the number of genetic loci and on the number of individuals. Hence, the use of a large number of loci, greater than 30 and preferably 50 or more, is needed. The number of loci used in this study was only 16 and sample size only 20 ;

3) Asexual reproduction can result in reduced genotypic diversity in a population by magnifying the effects of selection or random drift as reported by Innes and Yarish (1984) for Enteromorpha linza;

4) There may be have been a technical problem with the reading of the gels. For example, some isozymes may have been misidentified.

The phenogram of relationships between $G$. sordida populations using Nei's unbiased similarity (1978) (Figure 5.2) clearly divides G. sordida populations into two groups. Miller and Furneaux (1987) studied agar methylation and sulphation levels in a range of G. sordida populations and also separated G. sordida into two groups according to methylation level:

1)Low methylation level (24 - 30\%) found in the samples from Kaipara Harbour, Wellington Harbour, Aramoana and Bluff populations.

2)High methylation level (43 - $47 \%$ ) found in the samples from Manukau Harbour, 
Avon-Heathcote Estuary and Riverton populations.

When one compares the grouping of $G$. sordida populations produced by the electrophoretic phenogram in this study with the grouping obtained using methylation levels (Miller and Furneaux, 1987) the two major groups of each are correlated with the exception of the populations from Avon-Heathcote and Riverton Harbour.

The results seen in the phenogram indicate that there is a strong genetic similarity between the Shelly Beach population and Whitianga population, which is interesting since these two populations were morphologically distinct (see Appendix 8). The plants from Shelly Beach were long, slender, freely branching and dark brown in colour, but the plants from Whitianga were short, fat, rarely branching and yellow green in colour.

The phenogram showed that there was a clear difference in the allelic distribution between some localities, as detected by sampling the wild populations. It indicated that these populations were independent of each other. It could be explained on the assumption that the populations have a structure capable of being influenced by selection and random genetic drift. This seems a likely explanation for the low genetic variability of the wild populations and of the cultured populations. Similar low genetic variability was observed in G. tikvahiae (Penniman et al., 1985) and within groups of the marine plankton, e.q. Thalassiosira (Murphy and Guillard, 1976). However, a high genetic variability was observed in the red seaweed, Eucheuma, in which the proportion of polymorphic genes ranged from $25 \%$ to $36 \%$ (Cheney and Babbel, 1978) and in Porphyra yezoensis, in which the proportion of polymorphic loci averaged $39.8 \%$ (Miura et al., 1979).

There was no genetic variation among $G$. sordida plants from the same inlet (Pauatahanui) in Porirua Harbour but there was strong evidence that there are two genetically distinct populations of G. sordida in Manukau Harbour, one represented by the Puketutu Island population and the other by the populations of Hillsborough Bay and Blockhouse Bay. There are no obvious reasons to explain this variation but the movement of boats between harbours and harbours sites in New Zealand could influence variation. 
It is generally accepted that isozyme electrophoresis is a powerful tool for detecting genetic variation. However, two potential weaknesses of this technique for population genetical analysis should be noted.

First, only structural loci encoding water-soluble proteins are sampled.

Second, not all amino acid substitutions will alter the charge of the resulting protein. Therefore, it is generally estimated that electrophoresis detects no more than $30 \%$ of genetic variation at sampled loci, thus providing a minimum estimate of variation (Daugherty et al. 1981).

\subsection{CONCLUSION.}

This study indicates that there is little genetic variation within G. sordida from 17 sites around New Zealand. Most of the loci showed no electrophoretic variation and are assumed to be monomorphic. Only two of the 20 loci (Gd-1 and Pgm-1) are considered polymorphic. Estimates of heterozygosity are low and genetic distances between populations are small. Genetic distances in the phenogram show that the South Island populations are grouped together, but that the North Island populations are separated into two groups. The population structure of $G$. sordida has a tendency to split into a number of local populations.

However, these results were based on only G. sordida from 17 sites in New Zealand examined at 20 loci. This work is only preliminary and expansion of the study to include an extended and detailed analysis of additional loci, additional sites and different life stages is needed.

The degree of correlation between the phenogram analysis results and the distribution pattern of the two methylation levels studied by Miller and Furneaux (1987) should be examined further by analysing the agar methylation levels of all populations in this study. 


\section{ACKNOWLEDGEMENTS.}

I am deeply grateful to my supervisor, Dr Margaret Gordon, who not only has always being available with advice, support and encouragement throughout this study but also has given me and my wife the opportunity to study at Victoria University and made my stay in New Zealand enjoyable.

I also would like to thank Prof. Ken Heyes and Dr Barry Sneddon for advice and encouragement.

The excellent technical assistance provided by George Grainger, Anne Conwell, Philippa Spackman, Maureen Cooper, Elizabeth Haines, Jackie Silvester, and Dean Stotter during the study is gratefully acknowledged.

I am thankful to Carl Stapleton, Drs Betty and Eric Terzaghi and Dr Graeme Lindsay for assistance in collecting seaweed samples.

I wish to thank Dr Bruce Sampson for support and for allowing me to use his computer and software.

I would also like to thank Dr Charlie Daugherthy, Dr Graeme Lindsay and Jennifer Hay for advice and suggestions about starch-gel electrophoretic techniques.

I am grateful to Dr Wendy Nelson, Dr Richard Furneaux and Tim Pickering for giving me some articles, data and seaweed samples.

I very much appreciate the skill, care and time that John Casey and Brett Robertson, Photographic Facility, devoted to reprinting many of the figures for this thesis.

I am indebted to Ross Renner, Institute of Statistics and Operations Research, for his assistance with the statistical analysis. 
Special thanks are due to Murray Robb, Jim Gellen and Alex Heatley for solving computer problems.

I am thankful to Jenny McDonald, Oceanographic Institute Library, for searching many references from the Compact Cambridge Computer Programme.

I wish to thank the New Zealand Govermment for a Ph.D. scholarship awarded to me by the Ministry of External Relations and Trade and for an equipment grant to enable me to set up the pilot seaweed farm at Pauatahanui Inlet.

Financial support by The Wellington Botanical Society for travel expenses involved in presenting a paper at The Third International Phycological Congress in Melbourne, Australia, is acknowledged. Electrophoresis expenses were funded by a grant from the New Zealand Lotteries Board.

Many thanks to all present and former Thai friends for help and assistance, especially to John and Supawadee (Nat) Grey for invaluable support. I also would like to thank John and Nitaya Campbell for their comments and for help in proof reading on a draft of this thesis.

Finally, I wish to thank my wife, Payao, for her love, patience, support and encouragement in every aspect. 


\section{REFERENCES.}

Abbott, I. A. 1988. Some species of Gracilaria and Polycavernosa from Thailand. In I. A. Abbott (ed.): Taxonomy of economic seaweeds. Vol. 2. California Sea Grant College Program. Califomia. pp. 137-150.

Allendorf, F. W., N. Mitchell, N. Ryman and G. Stahl 1977. Isozyme loci in brown trout (Salmo trutta L.) detection and interpretation from population data. Hereditas 86: 179-190.

Amarasuriya, A. 1976. The Vertical and Horizontal Distribution of Crabs on the Upper Shoreline in the Pauatahanui Inlet, Wellington. B.Sc. Hons Thesis. Victoria University of Wellington, New Zealand, Pp. 39.

Asare, S. O. 1980. Seasonal changes in sulphate and 3,6-anhydrogalactose content of phycocolloids from two red algae. Bot. mar. 23: 595-598.

Benson, P. H. and K. T. Bird 1987. Seaweed Cultivation for Renewable Resources. Elsevier Science Publishers, New York, pp. 5-12.

Bird, C. J., J. McLachlan and E. C. de Oliveira 1986. Gracilaria chilensis sp. nov. (Rhodophyta, Gigartinales) from Pacific South America. Can. J. Bot. 64: 2928-2934.

Bird, C. J., R. J. Helleur, E. R. Hayes and J. McLachlan 1987. Analytical pyrolysis as a taxonomic tool in Gracilaria (Rhodophyta: Gigartinales). Proc. int. Seaweed Symp. 12: $207-211$.

Bird, C. J. and E. L. Rice 1990. Recent Approaches to the Taxonomy of the Gracilariaceae (Rhodophyta) and the Gracilaria verrucosa Problem. National Research Council of Canada, Pp. 21.

Bird. K. T. 1988. Agar production and quality from Gracilaria sp. strain G-16: effects of 
environmental factors. Bot. mar. 31: 33-39.

Bird, K. T., C. Harbig and T. DeBusk 1982. Nitrogen allocation and storage patterns in Gracilaria tikvahiae (Rhodophyta). J. Phycol. 18: 344-348.

Bird, K. T., M. D. Hanisak and J. Ryther 1981. Chemical quality and production of agars extracted from Gracilaria tikvahiae grown in different nitrogen enrichment conditions. Bot. mar. 24: 441-444.

Bird, N. L., L. C. M. Chen and J. McLachlan 1979. Effects of temperature, light and salinity on growth in culture of Chondrus crispus, Furcellaria lumbricalis, Gracilaria tikvahiae (Gigartinales, Rhodophyta) and Fucus serratus (Fucales, Phaeophyta). Bot. mar. 22: 521-527.

Bird, N. L., J. McLachlan and D. Grund 1977. Studies on Gracilaria 5. In vitro life history of Gracilaria sp. from the maritime provinces. Can. J. Bot. 55: 1282-1290.

Blair, S., A. Mathieson and D. Cheney 1982. Morphological and electrophoretic investigations of selected species of Chaetomorpha (Chlorophyta, Cladophorales). Phycologia 21: 164-172.

Boney, A. D. 1966. A Biology of Marine Algae. Hutchison Biological Monograph. London, Pp. 216.

Boonak, K. 1935. Agar from seaweed from Siam. Docum. Dep. Sci. 5. Ministry of Industry, Bangkok, pp. 1-12. (in Thai).

Brasch, D. J., C. T. Chuah and L. D. Melton 1983. The agar-type polysaccharide from the red alga Gracilaria secundata. Carbohydr. Res. 115: 191-198.

Brown, M. T., L. D. Melton and D. J. Brasch 1989. Why farm seaweeds?. In M. F. Beardsell (ed.): Proceedings of AQUANZ'88. A National Conference on Aquaculture. New Zealand Fisheries Occasional Publication No.4. pp. 65-70.

Camara Neto, C. 1987. Seaweed culture in Rio Grande de Norte, Brazil. Proc. int. Seaweed Symp. 12: 363-367. 
Carrol, M. A. 1988. Restriction fragment length polymorphisms in the red alga Gracilaria tikvahiae. Abstracts. IIrd Int. Phycol. Congr. Melbourne, Australia, Aug 14-20 : 7.

Chapman, V. J. 1979. The Marine Algae of New Zealand. Part III. Rhodophyceae, Issue 4. J. Cramer, Germany, pp. 290-302.

Chapman, V. J. and D. J. Chapman 1980. Seaweeds and Their uses. 3rd. ed. Chapman and Hall, London, Pp.334.

Chapman, A. R. O. and J. S. Craigie 1977. Seasonal growth by Laminaria longicruris: relations with dissolved inorganic nutrients and internal reserves of nitrogen. Mar. Biol. 40: 197-205.

Chen, M. Q. and G. Z. Ren 1987. The effect of temperature on the early growth and development of sporelings of Gracilaria asiatica Zhang and Xia. Oceanol. Limnol. Sin. 18: 301-308.

Cheney, D. P. 1985. Electrophoresis. In M. K. Littler and D. S. Littler (eds): Handbook of Phycological Methods. Ecological Field Methods: Macroalgae. Cambridge University Press, London, pp. 87-119.

Cheney, D. and G. Babbel 1978. Biosystematic studies of the red algal genus Eucheuma. 1. Electrophoretic variation among Florida populations. Mar. Biol. 47: 251-264.

Cheng, T. H. 1969. Production of kelp - a major aspect of China's exploration of the sea. Eco. Bot. 23(3): 215-236.

Chiang, Y-M. 1981. Cultivation of Gracilaria (Rhodophyta, Gigartinales) in Taiwan. Proc. int. Seaweed Symp. 10: 569-574.

Christeller, J. T., R. Furneaux, M. E. Gordon, W. A. Laing, I. Miller, W. Nelson, B. D. Shaw and B. E. Terzaghi 1983. The Potential for Mariculture of Seaweeds in New Zealand. Technical Report No.18. Pp. 21.

Christeller, J. T. and W. A. Laing 1989. The effect of environment on the agar yield and gel characteristics of Gracilaria sordida (Rhodophyta). Bot. mar. 32: 447-455. 
Cote, G. L. and M. D. Hanisak 1986. Production and properties of native agars from Gracilaria tikvahiae and other red algae. Bot. mar. 29: 359-366.

Craigie, J. S. and C. Leigh 1978. Carrageenans and agars. In J. A. Hellebust and J. S. Craigie (eds): Handbook of Phycological Methods. Physiological \& Biochemical Methods. Cambridge University Press, London, pp. 109-131.

Craigie, J. S. and Z. C. Wen 1984. Effects of temperature and tissue age on gel strength and composition of agar from Gracilaria tikvahiae (Rhodophyta). Can. J. Bot. 62: $1665-1670$.

Darley, W. M. 1982. Basic Microbiology. Volume 9. Blackwell Scientific Publications, London, Pp. 168.

Daugherty, R. K. and K. T. Bird 1988. Salinity and temperature effects on agar production from Gracilaria verrucosa strain G-16. Aquaculture 75: 105-113.

Dawes, C. J. 1981. Marine Botany. John Wiley and Sons, New York, Pp. 628.

Dawes, C. J. 1987. The biology of commercial important tropical marine algae. In K. T. Bird and P. H. Benson (eds): Seaweed Cultivation for Renewable Resources. Elsevier Science Publishers, New York. pp. 155-190.

Dawes, C. J., C.-P. Chen, J. Jewett-Smith, A. Marsh and S. A. Watts 1984. Effect of phosphate and ammonium levels on photosynthetic and respiratory response of the red alga Gracilaria verrucosa. Mar. Biol. 78: 325-328.

Dawson, E. Y. 1966. Marine Botany. An introduction. Holt, Rinehart and Winston Inc., New York, pp. 242-259.

DeBoer, J. A. 1979. Effects of nitrogen environment on growth rate and phycocolloid content in Gracilaria foliifera and Neoagardhiella baileyi (Florideophyceae). Proc. int. Seaweed Symp. 9: 263-271.

DeBoer, J. A. 1981. Nutrients. In C. S. Lobban and M. J. Wynne (eds): The Biology of Seaweeds. Botanical Monographs. Vol.17. Blackwell Scientific Publications. 
Oxford, pp. 356-392.

DeBoer, J. A. and J. H. Ryther 1977. Potential yields from a waste-recycling algae mariculture system. In R. W. Krauss (ed.): The Marine Plant Biomass of the Pacific northwest coast. Oregon State University Press. pp. 231-249.

DeBoer, J. A., H. J. Guigli, T. L. Israel and C. F. D'Elia 1978. Nutritional studies of two red algae. I. Growth rate as a function of nitrogen source and concentration. J. Phycol. 14: 261-266.

DeBusk, T. A. and J. H. Ryther 1984. Effects of seawater exchange, pH and carbon supply on the growth of Gracilaria tikvahiae (Rhodophyceae) large-scale cultures. Bot. mar. 27: 357-362.

DeWreede, R. E. 1980. The effect of some physical and biological factors on a Sargassum muticum community, and their implication for commercial utilization. In I. A. Abbott, M. S. Foster and L. F. Eklund (eds): Pacific Seaweed Aquaculture. California Sea Grant College Programme. University of California Press. pp. 32-44.

Dixon, P. S. 1973. Biology of the Rhodophyta. Oliver and Boyd, London, Pp. 285.

Doty, M. S. 1971. Measurement of water movement in reference to benthic algal growth. Bot. mar. 14: 32-35.

Doty, M. S. 1979. Status of marine agronomy, with special reference to the tropics. Proc. int. Seaweed Symp. 9: 35-58.

Doty, M. S. 1982. Realizing a nation's potential in phycology. In R. T. Tsuda and Y-M. Chiang (eds): Cultivation and Utilization of Economic Algae. Proceeding of Republic of China-United States Cooperative Science Seminar on Cultivation and Utilization of Economic Algae. University of Guam Marine Laboratory. pp. 1-8.

Doty, M. S. and J. R. Fisher 1987. Experimental Culture of Seaweeds (Gracilaria sp.) in Penang, Malaysia. FAO. Bay of Bengal Programme. BOB/WP/52. Pp. 37.

Doty. M. S. and G. A. Santos 1983. Agar from Gracilaria cylindrica. Aquat. Bot. 15: 
299-306.

Dromgoole, F. I. 1980. Desiccation resistance of intertidal and subtidal algae. Bot. mar. 23: 149-159.

Duckworth, M., K. C. Hong and W. Yaphe 1971. The agar polysaccharides from Gracilaria sp. Carbohydr. Res. 18: 1-9.

Durairatnam, M. 1987. Studies of the yield of agar, gel strength and quality of agar of Gracilaria edulis (Gmel.) Silva from Brazil. Proc. int. Seaweed Symp. 12: 509-512.

Durairatnam, M. and N. d. Q. Santos 1981. Agar from Gracilaria verrucosa (Hudson) Papenfuss and Gracilaria sjoestedtii Kylin from northeast Brazil. Proc. int. Seaweed Symp. 10: 669-674.

Edelstein, T., C. Bird and J. McLachlan 1981. Preliminary field studies on Gracilaria sp. from the lower gulf of St. Lawrence, Canada. Proc. int. Seaweed Symp. 8: 320-322.

Edding, M., C. Leo'n and R. Ambler 1987. Growth of Gracilaria sp. in the laboratory. Proc. int. Seaweed Symp. 12: 375-379.

Edelstein, T., C. J. Bird and J. McLachlan 1976. Studies on Gracilaria 2. Growth under green-house conditions. Can. J. Bot. 54: 2275-2290.

Edwards, P., Somsak Boromthanarat and Diep Minh Tam. 1982. Seaweeds of economic importance in Thailand Part I. Field survey, Thai Government statistics and future prospects. Bot. mar. 25: 237-246.

FAO/SIDA Project, 1987. Experimental Culture of Seaweeds (Gracilaria sp.) in Penang, Malasia. FAO/SIDA Project Development small scale Fish. Bay of Bengal, Madras, India, Pp. 41.

Fernandez-Pato, C. 1989. Mariculture developments: Environmental effects and planning. Ocean \& Shoreline Management 12: 487-494.

Foster, M. S. 1980. The use of substratum manipulations in field studies of seaweed 
colonization and growth. In I. A. Abbott., M. S. Foster and L. F. Eklund (eds): Pacific Seaweed Aquaculture. California Sea Grant College Programme, University of California Press. pp. 23-32.

Fredericq, S. and M. H. Hommersand 1989. Proposal of the Gracilariales ord. nov. (Rhodophyta) based on an analysis of the reproductive development of Gracilaria verrucosa. J. Phycol. 25: 213-227.

Fredericq, S. and J. N. Norris 1985. Morphological studies on some tropical species of Gracilaria Grev. (Gracilariaceae, Rhodophyta): taxonomic concepts based on reproductive morphology. In I. A. Abbott and J. N. Norris (eds): Taxonomy of Economic Seaweeds, with Reference to some Pacific and Caribbean Species. California Sea Grant College Programme, Report T-CSGCP-011. University of California, La Jolla, pp. 137-155.

Friedlander, M. and C. J. Dawes 1984. Studies on spore release and sporeling growth from carpospores of Gracilaria foliifera (Forsskal) Borgessen var. angustissma (Harvey) Taylor. I. Growth response. Aquat. Bot. 19: 221-232.

Friedlander, M., Y. Lipkin and W. Yaphe 1981. Composition of agar From Gracilaria cf. verrucosa and Pterocladia capillacea. Bot. mar. 24: 595-598.

Friedlander, M., R. Shallev, T. Ganor, T. Strimling, A. Ben-Amotz, K. Klar and Y. Wax 1987. Seasonal fluctuations of growth rate and chemical composition of Gracilaria. cf. conferta in outdoor culture in Israel. Proc. int. Seaweed Symp. 12: 501-507.

Friedlander, M. and Y. Lipkin 1982. Rearing of agarophytes and carragenophytes under field conditions in the eastem Mediterranean. Bot. mar. 25: 101-105.

Friedlander, M. and N. Zelikovitch 1984. Growth rates, phycocolloid yield and quality of the red seaweeds, Gracilaria sp., Pterocladia capillacea, Hypnea musciformis, and Hypnea cornuta, in field studies in Israel. Aquaculture. 40: 57-66.

Fujio, Y., P. L. G. Kodaka and M. Hara 1985. Genetic differentiation and amount of genetic variability in natural populations of haploid laver Porphyra yezeonsis Jpn. J. Genet. 
60: $347-354$.

Fuller, W. A. 1976. Introduction to Statistical Time Series. John Wiley and Sons, New York, Pp. 470.

Gallagher, J. 1980. Population genetics of Skeletonema costatum (Bacillariophyceae) in Narrangansett Bay. J. Phycol. 16: 464-474.

Gellenbeck, K. W. and D. J. Chapman 1983. Seaweed uses: the outlook for mariculture. Endeavour 7(1): 31-37.

Glicksman, M. 1987. Utilization of seaweed hydrocolloids in the food industry. Proc. int. Seaweed Symp. 12: 31-47.

Glogau, M. L. 1985. The Effect of Light Quantity and Quality on the Growth of Gracilaria sp. nov. B.Sc. Project. Victoria University of Wellington, New Zealand, Pp. 113.

Goldstein, M. E. 1981. Field and laboratory studies on Gracilaria from Prince Edward Island, Canada. Proc. int. Seaweed Symp. 8: 331-335.

Gordon-Mills, E. 1986. Marine Phycocolloids in Asian-Pacific Region. Report on the Exploratory Trip for the Commonwealth Science Council Project (91-687/3). Pp. 20.

Grant, M. and V. Proctor 1980. Electrophoretic analysis of genetic variation in the Charophyta. 1. Gene duplication via polyploidy. J. Phycol. 16: 109-115.

Guerin, J. M. and K. T. Bird 1987. Effects of aeration on the productivity and agar quality of Gracilaria sp. Aquaculture 64: 105-110.

Guiseley, K. B. 1970. The relationship between methoxyl content and gelling temperature of agarose. Carbohydr. Res. 13: 247-256.

Hanisak, M. D. 1987. Cultivation of Gracilaria and other macroalgae in Florida for energy production. In K. T. Bird and P. H. Benson (eds): Seaweed Cultivation for Renewable Resources. Elsevier Science Publishers, Amsterdam, pp. 191-217.

Hanisak, M. D. and J. H. Ryther 1984. Cultivation biology of Gracilaria tiktahiae in the 
United States. Proc. int. Seaweed Symp. 11: 295-298.

Hansen, J. E. 1984. Strain selection and physiology in the development of Gracilaria mariculture. Proc. int. Seaweed Symp. 11: 89-94.

Hansen, J. E., J. E. Packard and W. T. Doyle 1981. Mariculture of Red Seaweeds. National Sea Grant College Programme. Washington, Pp. 40.

Healy, W. B. 1980. Pauatahanui Inlet-an Environmental Study. New Zealand Department of Scientific and Industrial Research. DSIR information series 141. Pp. 198.

Hodgson, L. M. 1984. Desiccation tolerance of Gracilaria tikvahiae (Rhodophyta). J. Phycol. 20: 444-446.

Hollenbeck, L. 1987. Economics and Marketing Summary. Agricultural Technology Transfer Project. Final Report. Hawaiian Agronomics (International)Inc. Hawaii, pp. 170-173.

Hollings, T. 1985. Seaweed Aquaculture for New Zealand. The Fishings Industry Board Bulletin. No.81. pp. 14-15.

Hopkinson, G. 1989. Indonesian seaweed plant gets Kiwi boost. NBR Weekly Review. July 7. p. 5.

Hoyle, M. D. 1975. The Literature Pertinent to the Red Algae genus Gracilaria in Hawaii. Technical Report. No.3. NOAA-Sea Grant Programme. Pp. 340.

Hoyle, M. D. 1978. Reproductive phenology and growth rates of two species of Gracilaria from Hawaii. J. exp. mar. Biol. Ecol. 35: 273-283.

Hunt, R. 1978. Plant Growth Analysis. Studies in Biology No.96. Edward Arnold Publisher, London, Pp. 248.

H.Z.Y.Z., 1979. Cultivation of Seaweeds. Agriculture Press, Beijing, pp. 518-564. (in Chinese).

Innes. D. J. and C. Yarish 1984. Genetic evidence for the occurrence of asexual 
reproduction in population of Enteromorpha linza (L.) J. Ag. (Chlorophyta, Uvales) from Long Island Sound. Phycologia. 23: 311-320.

Intasuwan, Payao. 1990. Seasonal Variations in Agar Yield and Gel Strength of Gracilaria sordida W.A. Nelson in New Zealand. Diploma in Applied Science Project. Victoria University of Wellington, New Zealand, Pp. 47.

Irwin, J. 1976. Morphological stability of Pauatahanui Inlet, Porirua Harbour. N.Z. J. mar Freshwat. Res. 10: 641-650.

Jackson, G. A. 1980. Marine biomass production through seaweed aquaculture. In A. San Pietro (ed.): Biochemical and Photosynthetic Aspects of Energy Production. Academic Press, New York, pp. 31-58.

John, D. M. and S. O. Asare 1975. A preliminary study of the variations in yield and properties of phycocolloids from Ghanain seaweeds. Mar. Biol. 30: 325-330.

Johnson, K. A. 1981. Gracilaria Aquaculture Project. Final Report to A.R.A. Research Advisory Subcommittee. Auckland Regional Authority Internal Report. Pp. 29.

Jones, W. E. 1956. Effect of spore coalescence on the early development of Gracilaria verrucosa (Hudson) Papenfuss. Nature 178: 426-427.

Kain, J. M. 1987. Seasonal growth and photoinhibition in Plocamium cartilagineum (Rhodophyta) off the Isle of Man. Phycologia 26: 88-99.

Katada, M. 1955. Fundamental studies on the propagation of Gelidiaceous algae with special reference to shedding and adhesion of the spore germination, growth and vegetative reproduction. J. Shimonoseki. Coll. Fish. 5(1): 1-87.

Kim, C. S. and H. J. Humm 1965. The red algae, Gracilaria foliifera, with special reference to the cell wall polysaccharides. Bull. Mar. Sci. 15(4): 1036-1050.

Kim, D. H. 1970. Economically important seaweeds, in Chile, Gracilaria. Bot. mar. 13: 140-162. 
Kim, D. H. and N. P. Henriquez 1978. Yields and gel strengths of agar from cystocarpic and tetrasporic plants of Gracilaria verrucosa (Florideophyceae). Proc. int. Seaweed Symp. 9: 257-262.

Krishnamurthy, V. 1965. Marine algae cultivation-necessity, principles and problems. In V. Krishnamurthy (ed.): Proc. Sem. on Sea, Salt and Plants. India. pp. 327-333.

Krishnamurthy, V. 1988. Criteria in the taxonomy of Gracilaria Greville. Abstracts. IIIrd Int. Phycol. Congr. Australia, Aug. 14-20. p. 24.

Lahaye, M., C. Rochas and W. Yaphe 1986. A new procedure for determining the heterogeneity of agar polymers in the cell walls of Gracilaria spp. (Gracilariaceae, Rhodophyta). Can. J. Bot. 64: 579-585.

Lahaye, M. and W. Yaphe 1988. Effects of seasons on the chemical structure and gel strength of Gracilaria pseudoverrucosa agar (Gracilariaceae, Rhodophyta). Carbohydr. Polym. 8: 285-301.

Lapointe, B. E. 1981. The effects of light and nitrogen on growth, pigment content, and biochemical composition of Gracilaria foliifera v. angustissma (Gigartinales, Rhodophyta). J. Phycol. 17: 90-95.

Lapointe, B. E. and C. S. Duke 1984. Biochemical strategies for growth of G. tikvahiae (Rhodophyta) in relation to light intensity and nitrogen availability. J. Phycol. 20: 488-495.

Lapointe, B. E., L. D. Williams, J. C. Goldman and J. H. Ryther 1976. The mass outdoor culture of macroscopic marine algae. Aquaculture 8: 9-21.

Lapointe, B. E. and J. H. Ryther 1979. The effects of nitrogen and seawater flow rate on the growth and biochemical composition of $G$. foliifera var. angustissima in mass outdoor cultures. Bot. mar. 22: 529-537.

Lewmanomont, K. 1978. Some edible algae of Thailand. The Kasetsart Journal. 12(2): 119-129. (in Thai). 
Lewmanomont, K. 1987. Progress report on biology of Gracilaria. In T. F. Mumford (ed.); Third Progress Report for the Agriculture Technology Transfer Project. Hawaiian Agronomics (International) Inc., pp. 33-42.

Levine, I. A. 1988. Environmental Effects upon the Development of the Early Life History Stages of Gracilaria coronopifolia and Gracilaria pavispora. Ph.D. Thesis. University of Hawaii. Pp. 547.

Levring, T. 1957. Some modern aspects of growth and reproduction in marine algae in different regions. Annee Biologique 33: 57-65.

Levring, T. 1969. Marine Algae: A Survey of Research and Utilization. Cram de Gruyter \& Co, Hamburg, Pp. 421.

Lewis, J. C., N. F. Stanley and G. G. Guist 1988. Commercial production and applications of algal hydrocolloids. In C. A. Lembi and J. R. Waaland (eds): Algae and Human Affairs. Cambridge University Press, New York, pp. 205-235.

Li, R. Z., R. Y. Chong and Z. C. Meng 1984. A preliminary study of raft cultivation of Gracilaria verrucosa and Gracilaria sjoestedtii. Proc. int. Seaweed Symp. 11: 252-254.

Lignell, A. 1988. Physiology and Cultivation of Marine Seaweeds with Emphasis on Gracilaria secundata (Rhodophyta, Gigartinales). Ph.D. Thesis. Uppsala University. Sweden.

Lignell, A. and M. Pedersen 1986. Spray cultivation of seaweeds with emphasis on their light requirement. Bot. mar. 19: 509-516.

Lignell, A. and M. Pedersen 1987. Cultivation technique for marine seaweeds allowing controlled and optimized conditions in the laboratory and on a pilot-scale. Bot. mar. 30: 417-424.

Lignell, A. and M. Pedersen 1987. Nitrogen metabolism in Gracilaria secundata. Harv. Proc. int. Seaweed Symp. 12: 431-441. 
Lignell, A. and M. Pedersen 1989. Effects of $\mathrm{pH}$ and inorganic carbon concentration on growth of Gracilaria secundata. Br. Phycol. J. 24: 83-89.

Lindsay, J. C. and R. G. Saunders 1977. Growth and Enhancement of the Agarophyte Gracilaria. Fisheries Management Report. No.8 British Columbia Marine Resources Branch, Canada, Pp. 73.

Lindsay, J. C. and R. G. Saunders 1980. Evaluation of Enclosed Culture of Gracilaria. Fisheries Development Report No.27. British Columbia, Canada, Pp. 42.

Lindstrom, S. C. and G. R. South 1989. Evidence of species relationships in the Palmariaceae (Palmariales, Rhodophyta) based on starch gel electrophoresis. Crypt. Bot. 1: $32-41$.

Lipkin, Y., S. Beer, E. P. H. Best, T. Kairesaro and Salonen 1986. Primary production of macrophytes: Terminology, approaches and a comparison of methods. Aquat Bot. 26: 129-142.

Liu, C. Y., C. Y. Wang and S. S. Yang 1981 Seasonal variation of the chlorophyll contents of Gracilaria cultivated in Taiwan. Proc. int. Seaweed Symp. 10: 455-460.

Luxton, D. M. 1977. Aspects of Biology and Utilization of Pterocladia and Gracilaria. Ph.D. Thesis. University of Auckland, New Zealand, Pp. 237.

Luxton, D. M., M. Robertson and M. J. Kindley, 1987. Farming of Eucheuma in the south Pacific islands of Fiji. Proc. int. Seaweed Symp. 12: 359-362.

Madlener, J. C. 1977. The Seavegetable Book. C. N. Potter, New York, Pp. 288.

Marsh, R. N. 1985. Opportunities for, and Constraints on, Commercial Cultivation of Gracilaria: Policy Options. M.Sc. Thesis. Center for Resource Management. University of Canterbury and Lincoln College. New Zealand, Pp. 137.

Mathieson, A. C. 1975. Seaweed Aquaculture. Marine Fisheries Review. 37(1): 2-14.

Mathieson, A. C. 1981. Seaweed Cultivation: a review. In C. J. Sinderman (ed.). 
Proceedings of the Sixth U.S.-Japan Meeting on Aquaculture. U.S. Department of Commerce, Washington D.C, pp. 25-34.

Matsumoto, M. 1959. Effects of environmental factors on the growth of Nori (Porphyra tenera Kjellm.) with special reference to water current. Dept. of Fish and Vet. Sci. J. Hiroshima University. 2: 249-333.

May, V. 1948. The algal genus Gracilaria in Australia. Commonw. Australia. Coun. Sci. Ind. Res. Bull. 235. Pp. 64.

McCandless, E. L. 1981. Polysaccharides of the seaweeds. In C. S. Lobban and M. J. Wynne (eds) : The Biology of Seaweeds. Blackwell Scientific Publications. New York, pp. 539-588.

McHugh, D. G. and B. V. Lanier 1983. The World Seaweed Industry and Trade: Developing Asian Producers and Prospects for Greater Participation. ADB/FAO Infofish Market Studies. Vol.6. Pp. 30.

McLachlan, J. and C. J. Bird 1986. Gracilaria (Gigartinales, Rhodophyta) and productivity. Aqua. Bot. 26: 27-49.

McLachlan, J. and T. Edelstein 1977. Life history and culture of Gracilaria foliifera (Rhodophyta) from south Devon. J. Mar. Biol. Ass. U.K. 57: 577-586.

Michanek, G. 1978. Trends in applied phycology with a literature review: seaweed farming on an industrial scale. Bot. mar. 21: 469-475.

Michanek, G. 1981. Getting seaweed to where it's needed. Cress 14: 41-44.

Miller, I. J. 1979. Seaweed Extracts as Potential Raw Materials: the Galactans of the Rhodophyceae. DSIR. Chemistry Division Report No. C.D.2275. Pp. 33.

Miller, I. J. and R. H. Furneaux 1987. Chemical characteristics of the galactans from the forms of Gracilaria secundata from New Zealand. Bot. mar. 30: 427-435.

Miura, W., Y. Fujio and S. Suto 1979. Genetic differentiation between the wild and cultured 
populations of Porphyra yezoensis. Tohoku Journal of Agricultural Research 30(3): 114-125.

Moeller, H. W., S. M. Garber and G. F. Griffin 1984. Biology and economics of growing seaweeds on land in a film culture. Proc. int. Seaweed Symp. 11: 299-302.

Mumford, T. F. 1979. Field and laboratory experiments with Iridaea cordata (Florideophyceae) grown on nylon netting. Proc. int. Seaweed Symp. 9: 515-523.

Mumford, T. F. 1987. Agricultural Technology Transfer Project. Seaweed Production and Processing. Final Report. Vol 1-2. Hawaiian Agronomics (International) Inc., Hawaii, Pp. 77(Vol 1), 176(Vol 2).

Murphy, L. and R. Guillard 1976. Biochemical taxonomy of marine phytoplankton by enzyme electrophoresis. I. The centric diatoms Thalassiosira pseudonana Hasle \& Heimdal. and Thalassiosira fluviatilis Hustedt. J. Phycol. 12: 9-13.

Nei, M. 1978. Estimation of average heterozygosity and genetic distance from a small number of individuals. Genetics 89:583-590.

Neish, I. C. 1979. Culture of algae and seaweeds. In T. V. R. Pillay (ed.): Advances in Aquaculture. FAO Technical Conference. Fishing News Books Ltd. New York, pp. 395-415.

Nelson, W. A. 1987. Seaweeds- useful, and used, around the world. Catchs. 14(2): 9-11.

Nelson. W. A. 1988. The New Zealand species of Gracilaria Greville (Rhodophyta, Gigartinales). N. Z. J. Bot. 25: 87-98.

Nelson, W. A. 1989. Phenology of Gracilaria W. Nelson. Populations. Reproductive status, plant and population size. Bot. mar. 32: 41-51.

Nelson, S. G., R. N. Tsutsui and B. R. Best 1980. Preliminary evaluation of the mariculture potential of Gracilaria (Rhodophyta) in Micronesia: growth and ammonia uptake. In I. A. Abbott., M. S. Foster and L. F. Eklund (eds): Pacific Seaweed Aquaculture. California Sea Grant College Programme. University of California Press. pp. 72-79. 
Nelson, S. G., S. S. Yang, C. Y. Wang and Y. M. Chiang 1983. Yield and quality of agar from species of Gracilaria (Rhodophyta) collected from Taiwan and Micronesia. Bot. mar. 26: 361-366.

Ngan, Y. and I. R. Price 1979. Systematic significance of spore size in the Florideophyceae (Rhodophyta). Br. phycol. J. 14: 285-303.

Ngan, Y. and I. R. Price 1983. Periodicity of spore discharge in tropical Florideophyceae (Rhodophyta). Br. phycol. J. 18: 83-95.

Nisizawa, K., H. Noda, R. Kikuchi and T. Watanabe 1987. The main seaweed foods in Japan. Proc. int. Seaweed Symp. 12: 5-29.

Norton, T. A., A. C. Mathieson and M. Neushul 1981. Morphology and environment. In C. S. Lobban and M. J. Wynne (eds): The Biology of Seaweeds. Botanical Monographs Vol.17. Blackwell Scientific Publication. pp. 421-451.

Ogata, E., T. Matsui and H. Nakamura 1972. The complete life cycle of Gracilaria verrucosa in vitro. Proc. int. Seaweed Symp. 7: 135.

Ohmi, H. 1958. The Species of Gracilaria and Gracilariopsis from Japan and Adjacent Water. Faculty of Fisheries, Hokkaido University. pp. 1-66.

Okazaki, A. 1971. Seaweeds and Their Uses in Japan. Tokai University Press, Tokyo, Pp. 165.

Oliveira, E. C. de 1984. Taxonomic criteria in the genus Gracilaria (Rhodophyta, Gigartinales) in the western Atlantic. Gracilaria domingensis, G. cervicornis and G. ferox. Can. J. Bot. 61: 2999-3008.

Olsen, G. P. 1986. Report on Investigation into Feasibility of Spray Culture of Gracilaria in New Zealand. N.Z.F.I.B. Aquaculture Section File No.38/01. Pp. 12.

Oza, R. M. 1975. Studies on Indian Gracilaria. I. Carpospore and tetraspore germination and early stages of development in Gracilaria corticata J. Ag. Bot. mar. 18: 
Oza, R. M. 1978. Studies on Indian Gracilaria IV. Seasonal variation in agar and gel strength of Gracilaria corticata J. Ag. occurring on the coast of Veraval. Bot. mar. 21: 165-167.

Oza, R. M. and V. Krishnamurthy 1967. Studies on carposporic rhythm of Gracilaria verrucosa (Huds.) Papenf. Bot. mar. 9: 118-121.

Parker, H. S. 1982. Effects of simulated current on the growth rate and nitrogen metabolism of Gracilaria tikvahiae (Rhodophyta) Mar. Biol. 69: 137-145.

Patwary, M. U. and J. P. van der Meer 1983. Genetics of Gracilaria tikvahiae (Rhodophyceae) IX: some properties of agars extracted from morphological mutants. Bot. mar. 26: 295-299.

Penniman, C. A. and A. C. Mathieson 1987. Variation in chemical composition of $G$. tikvahiae McLachlan (Gigartinales, Rhodophyta) in the Great Bay Estuary, New Hampshire. Bot. mar. 30: 525-534.

Penniman, C. A., C. D. Neefus, A. C. Mathieson and R. T. Eckert 1985. Physiological and genetic variations of seaweed populations having disjunct distributions in the northwest Atlantic. Abstracts of the Second International Phycological Congress. 4-10 Aug. Copenhagen, Denmark, p. 124.

Pickering, T. D. 1986. Gracilaria: a food for cultured paua?. Catch. 13(4): 7.

Pickering, T. D. 1989. Farming the red seaweed Gracilaria sordida in New Zealand. In M. F. Beardsell (ed.): Proceeding of AQUANZ'88. New Zealand Fisheries Occasional Publication. No.4. MAFFish, Wellington, New Zealand, pp. 68-70.

Pickering, T. D. 1990. Growth, Phenology, Agar Quality and Food Quality for Abalone of the Red Seaweed Gracilaria sordida. Ph.D. Thesis. School of Biological Sciences, Victoria University of Wellington, New Zealand, Pp. 322.

Pizarro, A. and H. Barrales 1986. Field assessment of two methods for planting the agar-containing seaweed, Gracilaria, in northern Chile. Aquaculture 59: 31-43. 
Provasoli, H. 1963. Growing marine seaweeds. Proc. int. Seaweed Symp. 4: 9-17.

Raju, P. V. and P. C. Thomas 1971. Experimental field cultivation of Gracilaria edulis (GMEL) Silva. Bot. mar. 15: 71-75.

Ramus, J., S. I. Beale and D. Mauzerall 1976. Correlation of changes in pigment content with photosynthetic capacity of seaweeds as a function of water depth. Mar. Biol. 37: $231-238$.

Rangaiah, G. S. 1985. Spore shedding in Gracilariopsis sjoestedtii (Rhodophyta, Gigartinales). In V. Krishnamurthy and A.G. Untawale (eds) : Marine Plants. Paper presented at the All-India Symposium on Marine Plants, Their Biology, Chemistry and Utilization, Oct 30-Nov 1, Dona Paula, Goa, India, pp. 59-64.

Reading, R. P. and C. W. Schneider 1986. On the male conceptacles of two terete species of Gracilaria (Rhodophyta, Gigartinales) from North Carolina. J. Phycol. 22: 395-398. 
foliifera (Rhodophyceae) and Ulva sp (Chlorophyceae): soluble nitrogen and reserve carbohydrates. Mar.Biol. 66: 251-259.

Rotem, A., N. Roth-Bejerano and S. M. Arad 1986. Effect of controlled environmental conditions on starch and agar contents of Gracilaria sp. (Rhodophyceae). J. Phycol. 22: 117-121.

Rotmann, K. W. G. 1987. The collection, utilization and potential farming of red seaweeds in Namibia. Proc. int. Seaweed Symp. 12: 301-305.

Rueness, J. and T. Tananger 1984. Growth in culture of four red algae from Norway with potential for mariculture. Proc. int. Seaweed Symp. 11: 303-307.

Rueter, J. C. and D. H. Robinson 1986. Inhibition of carbon uptake and stimulation of nitrate uptake at low salinities in Fucus distichus (Phaeophyceae). J. Phycol. 22: 243-246.

Ryther, J. H. 1963. International Indian Ocean Expedition. AIBS. Bull. 13(5): 48-51.

Ryther, J. H., J. A. DeBoer and B. E. Lapoint 1979. Cultivation of seaweeds for hydrocolloids, waste treatment and biomass for energy conversion. Proc. int. Seaweed Symp. 9: 1-16.

Ryther, J. H., N. Corwin, T. A. DeBusk and I. D. Williams 1981. Nitrogen uptake and storage by the red alga Gracilaria tikvahiae (McLachlan). Aquaculture 26: 107-115.

Santelices, B. and M. S. Doty 1989. A Review of Gracilaria farming. Aquaculture 78: 95-133.

Santelices, B., J. Vasques, U. Ohme and E. Fonck 1984. Managing wild crops of Gracilaria in central Chile. Proc. int. Seaweed Symp. 11: 77-89.

Santelices, B. and R. Ugarte 1987. Production of Chilean Gracilaria : problems and prospectives. Proc. int. Seaweed Symp. 12: 295-299.

Santos, G. A. 1987. Processing of Agar from the Marine Algae of Thailand. Agricultural 
Technology Transfer Project. Final Report. Hawaiian Agronomics (International) Inc., Hawaii, pp. 144-154.

Santos, G. A. 1980. Quality of carrageenan and agar. In I. A. Abbott., M. S. Foster and L. F. Eklund (eds): Pacific Seaweed Aquaculture Califomia Sea Grant College Programme. California, pp. 123-129.

Santos, G. A. and M. S. Doty 1983. Agarose from Gracilaria cylindrica. Bot. mar. 26: 31-34.

Saunders, R. G. and J. E. Lindsay 1979. Growth and enhancement of the agarophyte Gracilaria (Florideophyceae). Proc. int. Seaweed Symp. 9: 249-255.

Selander, R. K., M. K. Smith, S. Y. Yang, W. E. Johnson and J. B. Gentry 1971. Biochemical polymorphisms and systematics in genus Peromyscus. I. Variation in the old-field mouse, Peromyscus polionotus. Studies in Genetics, University of Texas Publications 7103: 49-90.

Shang, Y. C. 1976. Economic aspects of Gracilaria culture in Taiwan. Aquaculture 8: 1-7.

Shaw, C. R. and R. Prasad 1970. Starch gel electrophoresis of enzymes. a compilation of recipes. Biochem. Genet. 4: 297-320.

Shi, S. Y., Z. Y. Xia, Z. E. Li and W. Q. Liu 1988. The yield and properties of agar extracted from different life stages of Gracilaria verrucosa. Proc. int. Seaweed Symp. 11: 551-553.

Shields, C. R., T. J. Orton and C. W. Stuber 1983. An outline of general resource needs and procedures for the electrophoretic separation of active enzymes from plant tissue. In S. D. Tanksley and T. J. Orton (eds). Isozymes in Plant Genetics and Breeding. Part A. Elsevier Science Publishers, Amsterdam, pp. 443-463.

Simonetti, G., G. Giaccone and S. Pignatti 1970. The seaweed Gracilaria confervoides, an important object for autecologic and cultivation research in the northern Adriatic sea. Helgol. Wiss. Meeresunters 20: 89-96. 
Sinchumpasak, O. 1980. Microalgal biomass production in Thailand. In. G. Shelef and G. J. Soeder (eds): Algal Biomass. Elsevier Science Publishers, Amsterdam, pp. 115-121.

Smith, A.H., K. Nichols and J. McLachlan 1984. Cultivation of seamoss (Gracilaria) in St. Lucia, West Indies. Proc. int. Seaweed Symp. 11: 249-251.

Soeder, C. and E. Stengel 1974. Physico-chemical factors affecting metabolism and growth rate. In W. D. P. Stewart (ed.): Algal Physiology and Biochemistry. Botanical Monograph Vol.10. Blackwell Scientific Publications, Oxford, pp. 714-740.

Soegiarto, A. 1978. Indonesian seaweed resources: their utilization and management. Proc. int. Seaweed Symp. 9: 463-471.

Soudek, D. and G. Robinson 1983. Electrophoretic analysis of the species and population structure of the diatom Asterionella formasa. Can. J. Bot. 61: 413-433.

South, G. R. and A. Whittick 1987. Introduction to Phycology. Blackwell Scientific Publications, Oxford, Pp. 341.

Stewart, W. D. P. 1974. Algal Physiology and Biochemistry. Blackwell Scientific Publications, Oxford, pp. 815-837.

Suto, S. 1950. Shedding, floating and fixing of spores of seaweeds. Bull. Jap. Soc. Sci. Fish. 16: 1-9.

Swofford, D. L. and R. B. Selander 1981. Biosys-1: A FORTRAN program for the comprehensive analysis of electrophoretic data in population genetics and systematics. J. Hered. 72: 281-283.

Sylvester, A. W. and J. R. Waaland 1984. Sporeling dimorphism in the red alga Gigartina exasperata Harvey \& Bailey. Phycologia 23: 427-432.

Tam, D. M. and P. Edwards 1982. Seaweeds of economic importance in Thailand. 2: analysis of agar from Gracilaria. Bot. mar. 25: 459-466. 
Terzaghi, B. E., W. A. Nelson and T. Hollings 1987. Gracilaria : cultivation, harvest, and uses. Fishdex 36: 1-4.

Thomas, P. C. and V. Krishnamurthy 1982. Agar from cultured Gracilaria edulis (Gmel.) Silva. Bot. mar. 19: 115-117.

Trono, G. C. 1986. Seaweed Culture in the Asia-Pacific Region. Regional Office for Asia and the Pacific (RAPA) Publication 1987/1988. Bangkok, Pp. 41.

Truong, H. H., P. Lesecq, I. Karamanos, Y. Quang, and D. Christiaen 1988. Chemical characterization of agar from agarophytes grown in the lagoon of Binh Tri Thien (Vietnam). Bot. mar. 31: 289-293.

Tseng, C. K. 1981. Commercial cultivation. In C. S. Lobban and M. J. Wynne (eds): The Biology of Seaweeds. Blackwell Scientific Publications, Boston, pp. 680-725.

Tseng, C. K. 1986. Laminaria mariculture in China. In M. S. Doty, J. F. Caddy and B. Santelices (eds): Case Study of Seven Commercial Seaweed Resources. FAO Fish. Tech. Pap. 281: 239-263.

Tseng, C. K. 1987. Some remarks on the kelp cultivation industry in China. In K. T. Bird and P. H. Benson (eds): Seaweed Cultivation for Renewable Resources. Elsevier Science Publishers, New York, pp. 147-153.

Tseng, C. K. and X. G. Fei 1987. Macroalgal commercialization in the orient. Proc. int. Seaweed Symp. 12: 167-172.

Umamaheswara Rao, M. 1972. Ecological observations on some intertidal algae of Mandapam coast. Proc. Indian Nat. Sci. Acad. 38: 298-307.

Umamaheswara Rao, M. 1976. Spore liberation in Gracilaria corticata J. Agardh growing at Mandapam. J. Exp. Mar. Biol. Ecol. 21: 91-98.

Umamaheswara Rao, M. and G. Subbarangaiah 1981. Effects of environmental factors on the diurnal periodicity of tetraspores of some Gigartinales (Rhodophyta). Proc. int. Seaweed Symp. 10: 209-214. 
University of Otago Marine Science Bulletin. 1990. March. 1: p. 5.

van der Meer, J. P. 1977. Genetics of Gracilaria sp. (Rhodophyceae, Gigartinales). II. The life history and genetic implications of cytokinetic failure during tetraspore formation. Phycologia 16: 367-371.

Velasquez, G. T. and K. Lewmanomont 1975. A checklist on the study of the benthic marine algae of Thailand. Kasetsart. Univ. Fish. Res. Bull. 8: 1-25.

Waaland, J. R. 1976. Growth of the red algae Iridaea cordata (Turner) Bory. in semi-closed culture. J. exp. mar. Biol. Ecol. 23: 45-53.

Wang, W. C. and S. S. Yang 1980. Seasonal variation of the quality of Gracilaria cultivated in Taiwan. Proc. Nat. Sci. Counc. Repub. China, 4: 78-86.

Whyte, J. N. C. and J. R. Englar 1980. Chemical composition and quality of agar in the morphotypes of Gracilaria from British Columbia. Bot. mar. 23: 277-283.

Whyte, J. N. C. and J. R. Englar 1982. Agar from an intertidal population of Gracilaria sp. Proc. int. Seaweed Symp. 10: 537-542.

Whyte, J. N. C., J. R. Englar, R. G. Saunders and J. C. Lindsay 1981. Seasonal variations in the biomass, quantity and quality of agar from the reproductive and vegetative stages of Gracilaria (verrucosa type). Bot. mar. 24: 493-502.

Wood, E. J. F. 1946. Agar in Australia. Council for Scientific and Industrial Research Bulletin. No. 203. Pp. 47.

Yamamoto, H. 1978. Systematic and anatomical study of the genus Gracilaria in Japan. Mem. Fac. Fish. Hokkaido University. 25(2): 97-152.

Yang, S. S. 1982. Seasonal variation of the quality of agar-agar produced in Taiwan. In R. T. Tsuda and Y. M. Chiang (eds): Proceedings of R.O.C.-U.S. Cooperative Science Seminar on Cultivation and Utilization of Economic Algae. University of Guam Marine Laboratory. pp. 65-80. 
Zhang, J. F. and B. M. Xia 1984. Some problems in the taxonomy of Chinese species of Gracilaria (Rhodophyta). Proc. int. Seaweed Symp. 11: 59-62. 
APPENDICES

Appendix 1. Modified Provasoli's nutrient medium.

Concentration(mg/l)

(1)

$\mathrm{NH}_{4} \mathrm{Cl}$

1482

$\mathrm{NaH}_{2} \mathrm{PO}_{4}$

170

(2)

$\mathrm{Na}_{2}$ EDTA.

$\mathrm{FeSO}_{4}\left(\mathrm{NH}_{4}\right)_{2} \mathrm{SO}_{4} 6 \mathrm{H}_{2} \mathrm{O}$.

$\mathrm{FeCl}_{3} 6 \mathrm{H}_{2} \mathrm{O}$.

\section{P.micro}

$\mathrm{H}_{3} \mathrm{BO}_{3}$

$\mathrm{MnSO}_{4}$

270

$\mathrm{ZnSO}_{4}$

36

$\mathrm{CoCl}_{2}$

8

P.vit

Thiamine

Biotin

Vitamin B12

2

Add (1), then (2) to $500 \mathrm{ml}$ distilled water. Dissolve P.micro in $100 \mathrm{ml}$ distilled water and add $10 \mathrm{ml} \mathrm{P.micro} \mathrm{to} \mathrm{the} 500 \mathrm{ml}$ above. Dissolve P.vit in $100 \mathrm{ml}$ distilled water and add $10 \mathrm{ml} \mathrm{P.vit} \mathrm{to} \mathrm{the} 500 \mathrm{ml}$ above. 
water and add $10 \mathrm{ml}$ P.micro to the $500 \mathrm{ml}$ above. Dissolve P.vit in $100 \mathrm{ml}$ distilled water and add $10 \mathrm{ml} \mathrm{P.vit} \mathrm{to} \mathrm{the} 500 \mathrm{ml}$ above.

Make up the solution to $1 \mathrm{l}$ and use at the rate of $20 \mathrm{ml}$ nutrient solution per litre of seawater. 
Appendix 2. Matrices of pairwise t-tests of the effects of environmental factors on total spore release of Gracilaria sordida.

Matrix of Pairwise t-tests of the effect of salinity on total spore release of Gracilaria sordida Above diagonal : carpospores

Below diagonal : tetraspores

\begin{tabular}{|c|c|c|c|c|c|c|c|c|}
\hline \multirow[b]{2}{*}{ salinity } & \multicolumn{2}{|c|}{$5 \mathrm{ppt}$} & \multicolumn{2}{|r|}{$15 \mathrm{ppt}$} & \multicolumn{2}{|c|}{$25 \mathrm{ppt}$} & \multicolumn{2}{|c|}{$35 \mathrm{ppt}$} \\
\hline & Sch & Pau & Sch & Pau & Sch & Pau & Sch & Pau \\
\hline $5 \mathrm{ppt}$ & & $* \star \star$ & 0.00 & 0.00 & 0.00 & 0.00 & 0.00 & 0.00 \\
\hline $15 \mathrm{ppt}$ & 0.00 & 0.00 & & $\star * * * * \star * * * *$ & 0.54 & 1.74 & $3.3^{*}$ & 0.18 \\
\hline $25 \mathrm{ppt}$ & 0.00 & 0.00 & $7.7^{*}$ & $2.4^{*}$ & & $* * \star$ & $5.7^{\star}$ & 0.95 \\
\hline $35 \mathrm{ppt}$ & 0.00 & 0.00 & $7.7^{\circ}$ & $10.4^{*}$ & 0.15 & $5.0^{*}$ & & \\
\hline
\end{tabular}

* Significant at $p<0.05$

Matrix of Pairwise t-tests of the effect of temperature on total spore release of Gracilaria sordida

Above diagonal : carpospores

Below diagonal : tetraspores

\begin{tabular}{|c|c|c|c|c|c|c|c|c|}
\hline \multirow[b]{2}{*}{ temperature } & \multicolumn{2}{|c|}{$15^{\circ} \mathrm{C}$} & \multicolumn{2}{|r|}{$20^{\circ} \mathrm{C}$} & \multicolumn{2}{|c|}{$25^{\circ} \mathrm{C}$} & \multicolumn{2}{|c|}{$30^{\circ} \mathrm{C}$} \\
\hline & Sch & Pau & Sch & $\mathrm{Pau}$ & Sch & Pau & Sch & Pau \\
\hline $15^{\circ} \mathrm{C}$ & & $* * * *$ & $5.9^{*}$ & $11.5^{*}$ & $18.9^{*}$ & $8.4^{*}$ & $8.7^{*}$ & $20.2^{*}$ \\
\hline $20^{\circ} \mathrm{C}$ & 0.47 & $8.6^{*}$ & & $* * * * * * * * *$ & $20.4^{*}$ & $3.9^{*}$ & $12.0^{*}$ & $12.2^{*}$ \\
\hline $25^{\circ} \mathrm{C}$ & $6.5^{\star}$ & $13.7^{*}$ & $5.0^{*}$ & $8.0^{\circ}$ & & $\cdots$ & $14.2^{\star}$ & $9.6^{\circ}$ \\
\hline $30^{\circ} \mathrm{C}$ & $13.2^{*}$ & $14.5^{\circ}$ & $9.8^{*}$ & $9.1^{*}$ & $6.4^{*}$ & $3.5^{\star}$ & & $\cdots$ \\
\hline
\end{tabular}

- Significant at $p<0.05$

Sch $=$ Scorching Bay $\mathrm{Pau}=$ Pauatahanui Inlet 
Appendix 2. Continued

Matrix of Pairwise t-tests of the effect of light intensity on total spore release of Gracilaria sordida

Above diagonal : carpospores

Below diagonal : tetraspores

\begin{tabular}{|c|c|c|c|c|c|c|c|c|}
\hline \multirow[b]{2}{*}{ light intensity } & \multicolumn{2}{|c|}{$50 \mu \mathrm{Em}^{-2} \mathrm{~s}^{-1}$} & \multicolumn{2}{|c|}{$100 \mu \mathrm{Em}^{-2} \mathrm{~s}^{-1}$} & \multicolumn{2}{|c|}{$150 \mu \mathrm{Em}^{-2} \mathrm{~s}^{-1}$} & \multicolumn{2}{|c|}{$200 \mu \mathrm{Em}^{-2} \mathrm{~s}^{-1}$} \\
\hline & Sch & Pau & Sch & $\mathrm{Pau}$ & Sch & Pau & Sch & $\mathrm{Pau}$ \\
\hline $50 \mu \mathrm{Em}^{-2} \mathrm{~s}^{-1}$ & & $\cdots \cdot$ & 0.04 & $11.5^{*}$ & 1.7 & $16.6^{*}$ & $3.3^{*}$ & $26.2^{*}$ \\
\hline $100 \mu E \mathrm{~m}^{-2} \mathrm{~s}^{-1}$ & $2.5^{*}$ & $6.5^{*}$ & & $n+* \cdots \cdots+\ldots$ & $2.7^{*}$ & $7.7^{*}$ & $5.1^{*}$ & $20.9^{*}$ \\
\hline $150 \mu E m^{2} s^{-1}$ & $4.4^{*}$ & $6.6^{*}$ & $7.9^{*}$ & $14.3^{\circ}$ & & n.... & $2.7^{*}$ & $10.9^{*}$ \\
\hline $200 \mu \mathrm{Em}^{-2} \mathrm{~s}^{-1}$ & $5.3^{*}$ & $13.9^{*}$ & $8.9^{*}$ & $22.2^{*}$ & 1.0 & $5.9^{*}$ & & \\
\hline
\end{tabular}

* Significant at $p<0.05$

Sch $=$ Scorching Bay $\mathrm{Pau}=$ Pauatahanui Inlet 
Appendix 2. Continued

Matrix of Pairwise t-tests of the effect of exposure time on total spore release of Gracilaria sordida Above diagonal: carpospores

Below diagonal: tetraspores

\begin{tabular}{|c|c|c|c|c|c|c|c|c|c|c|}
\hline \multirow{2}{*}{ exposure time } & \multicolumn{2}{|c|}{ on } & \multicolumn{2}{|c|}{$1 \mathrm{~h}$} & \multicolumn{2}{|c|}{$2 \mathrm{~h}$} & \multicolumn{2}{|r|}{$3 \mathrm{~h}$} & \multicolumn{2}{|c|}{$4 \mathrm{~h}$} \\
\hline & Sch & Pau & Sch & Pau & Sch & Pau & Sch & Pau & Sch & $\mathrm{Pau}$ \\
\hline $\mathrm{Oh}$ & & $\star * * *$ & $5.9^{*}$ & $1.4^{*}$ & $12.0^{\circ}$ & $12.9^{*}$ & $15.1^{*}$ & 1.8 & $4.9^{*}$ & $11.4^{*}$ \\
\hline $1 \mathrm{~h}$ & 0.02 & $5.6^{*}$ & \multicolumn{2}{|c|}{$* * * * * * *$} & $3.3^{*}$ & $1.9^{*}$ & $5.3^{*}$ & $12.9^{*}$ & $6.3^{*}$ & $30.6^{*}$ \\
\hline $2 \mathrm{~h}$ & $10.5^{*}$ & $10.3^{*}$ & $18.3^{*}$ & $6.9^{*}$ & \multicolumn{2}{|c|}{$+* * * * * *$} & $2.2^{*}$ & $13.0^{*}$ & $10.6^{\star}$ & $26.6^{*}$ \\
\hline $3 h$ & $4.8^{*}$ & $16.8^{*}$ & $8.4^{*}$ & $12.8^{*}$ & $6.4^{*}$ & $3.6^{*}$ & & $\star * * * * * * *$ & $10.3^{*}$ & $25.2^{*}$ \\
\hline $4 \mathrm{~h}$ & $5.7^{\star}$ & $6.9^{*}$ & $9.9^{*}$ & 0.02 & $5.1^{*}$ & $3.3^{*}$ & 1.5 & $6.4^{*}$ & \multicolumn{2}{|c|}{$* * * * * * *$} \\
\hline
\end{tabular}

* Significant at $p<0.05$ 
Appendix 3. Nitrogen analytical procedures

1. Analysis of nitrate using a nitrogen oxide electrode. Orion Model 95-46.

The nitrogen oxide electrode can be used for measurements of nitrite (in aqueous solutions) and of nitrate after conversion to nitrite. Nitrate can be converted to nitrite by copperized cadmium using a reduction column.

\subsection{Required equipment.}

1) Meter - Orion Model $720 \mathrm{pH}$-ISE meter

2) Magnetic stirrer

3) Graph paper 4-cycle semilogarithm paper for preparing calibration curves

\subsection{Required solutions}

1) Deionized water -to prepare all solutions and standards.

2) Standard solution -Orion $100 \mathrm{ppm}$ sodium nitrite standard

3) Acid buffer solution -Orion acid buffer.

4) Storage solution -to store electrode

5) Internal filling solution -to fill the electrode

6) $\mathrm{pH} 4$ buffer (with $0.1 \mathrm{M} \mathrm{NaCl}$ added)

7) $\mathrm{pH} 7$ buffer

\subsection{Sample storage}

Each seawater sample can be collected in a polythene bottle and should be measured at once. If samples required storage, add $0.6 \mathrm{~g}$ sodium dihydrogen phosphate to every $100 \mathrm{ml}$ sample to avoid loss of nitrogen oxide gases. 


\subsection{Analytical procedure}

1) Assemble the electrode. Allow the electrode to stand for $30 \mathrm{~min}$ in storage solution $\left(20^{\circ}\right.$ angle from vertical $)$.

2) Connect electrode to meter.

3) Place electrode in the $1 \mathrm{ppm}$ sodium nitrite standard solution. Set function switch to MV, stir gently, wait for stable potential reading and record.

4) Rinse electrode, blot dry, and place in the $10 \mathrm{ppm}$ sodium nitrite standard solution. Stir gently, wait for a stable potential reading, and record.

5) Plot the millivolt readings (linear axis) against concentration (log axis) on standard 4 cycle semilogarithmic paper.

6) Transfer $100 \mathrm{ml}$ of sample to $150 \mathrm{ml}$ beaker. Add $10 \mathrm{ml}$ acid buffer to each 100 ml sample.

7) Rinse electrode, blot dry, and place in sample. Stir gently. Record millivolt reading when stable. Determine sample concentration from calibration curve.

8) Recalibrate after 2 hours of use. 
2.Analysis of ammonia using an ammonia electrode (Orion Model 95-12)

Ammonia is present in seawater in two forms: ionized $\left(\mathrm{NH}_{4}\right)$ and un-ionized $\left(\mathrm{NH}_{3}\right)$. The Orion ammonia electrode is a gas sensing electrode; hence it is sensitive to the un-ionized form only.

\subsection{Required equipment.}

As for nitrogen oxide analysis.

\subsection{Required solutions.}

1) Ammonia free water. Pass deionized water through an ion-exchange column (50 $\mathrm{cm}$ long, $2.5 \mathrm{~cm}$ diameter) containing a strong acidic cation exchange resin (Dowex 50W-8X), flow rate $100 \mathrm{ml} \cdot \mathrm{min}^{-1}$.

2) $10 \mathrm{M} \mathrm{NaOH}$

3) Standard solution (100 ppm ammonium chloride).

4) Internal filling solution

5) $\mathrm{pH} 4$ and 7 buffers

\subsection{Analytical procedures.}

1) Place electrode in $10 \mathrm{ppm}$ ammonium chloride standard solution. Add $1 \mathrm{ml} 10 \mathrm{M}$ $\mathrm{NaOH}$ to each $100 \mathrm{ml}$ of standard. Set the function switch to REL MV. Set the reading to 000.0 by adjusting the calibration control. Use magnetic stirrer throughout the procedure.

2) Rinse electrode and place in the $1 \mathrm{ppm}$ ammonium chloride standard solution. Add $1 \mathrm{ml} 10 \mathrm{M} \mathrm{NaOH}$ to every $100 \mathrm{ml}$ of standard. Stir thoroughly. Wait for a stable reading and record.

3) Rinse electrode and place in the $100 \mathrm{ppm}$ ammonium chloride standard solution. Add $1 \mathrm{ml} 10 \mathrm{M} \mathrm{NaOH}$ to each $100 \mathrm{ml}$ of standard. Stir thoroughly. Wait for a stable reading and record.

4) Plot the millivolt reading (linear axis) against concentration (log axis) on standard 4 cycle semilogarithmic paper.

5) Rinse electrode and place in sample. Add $1 \mathrm{ml} 10 \mathrm{M} \mathrm{NaOH}$ to each $100 \mathrm{ml}$ of 
sample. Stir thoroughly. Record the millivolt reading and determine sample concentration from the calibration curve.

6) Recalibrate every two hours. 


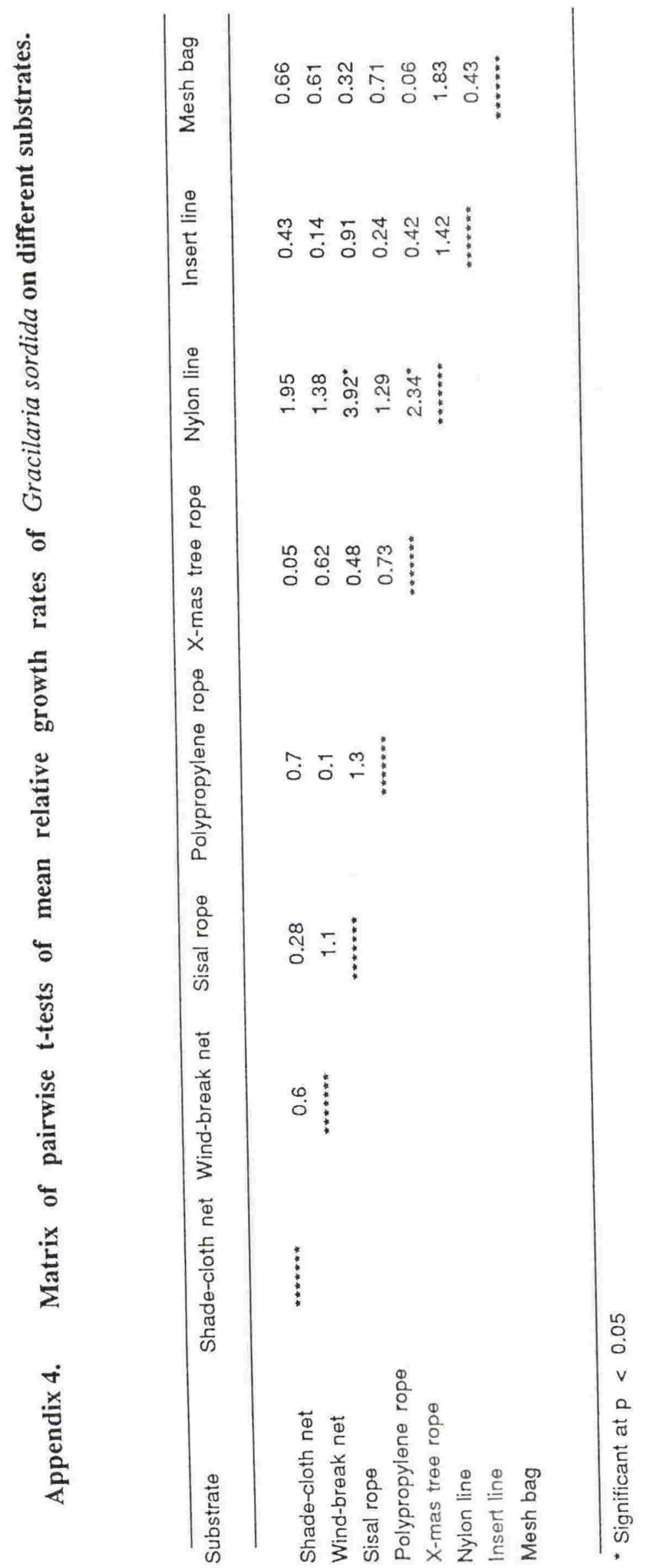




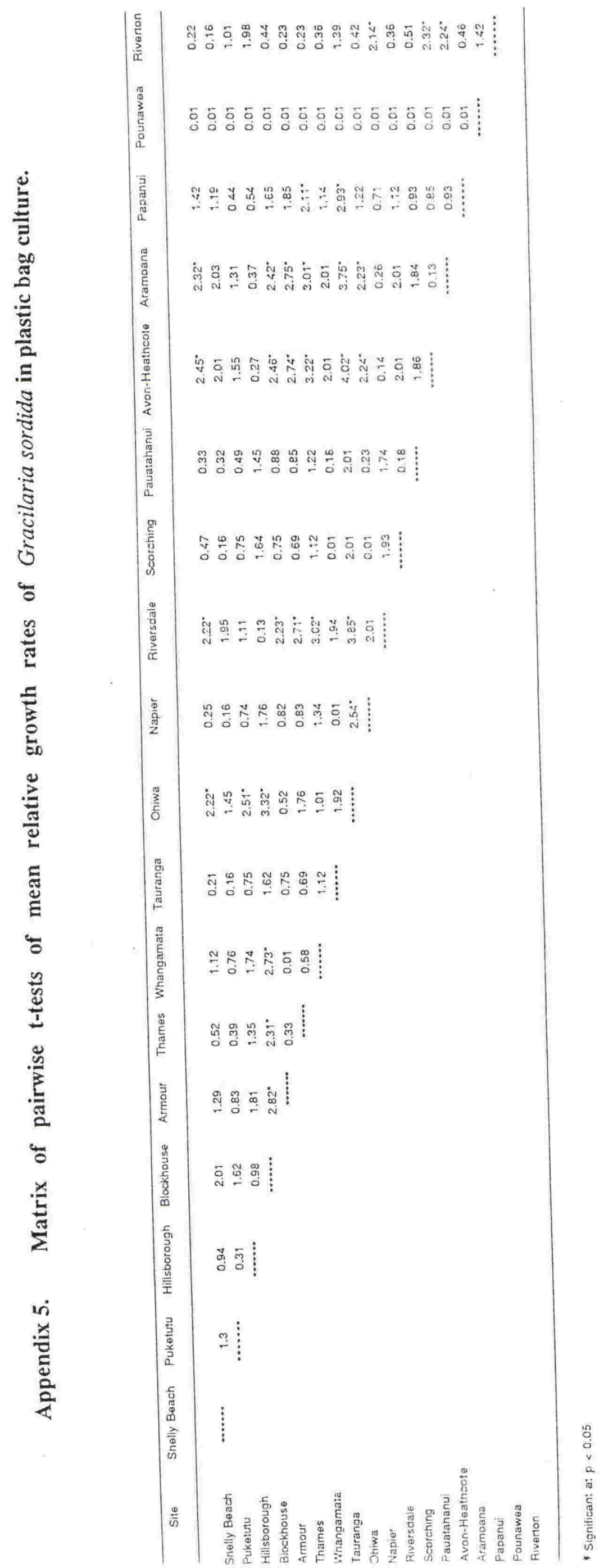


Appendix 6. Enzyme-specific stain recipes.

1. Aldolase (ALD)

$\begin{array}{ll}50 \mathrm{ml} & \text { Stain buffer II } \\ 250 \mathrm{mg} & \text { Fructose-1,6-diphosphate } \\ 75 \mathrm{mg} & \text { Arsenic acid } \\ * 40 \mathrm{u} & \text { Glyceraldehyde-phosphate dehydrogenase } \\ * 5 \mathrm{mg} & \text { NAD } \\ * 10 \mathrm{mg} & \text { NBT } \\ * 5 \mathrm{mg} & \text { PMS }\end{array}$

Incubate at $37^{\circ} \mathrm{C}$.

\section{B-Galactosidase (B-GAL)}

$25 \mathrm{ml} \quad 0.02 \mathrm{M}$ citrate/phosphate buffer $\mathrm{pH} 4.35$

$4.5 \mathrm{mg} \quad$ 4-me-umbelliferyl- $\beta$-D-galactoside

Incubate at $37^{\circ} \mathrm{C}$ for approx. $30 \mathrm{~min}$. View under UV.

\section{Catalase (CAT)}

(A)

$\begin{array}{ll}5 \mathrm{ml} & 3 \% \mathrm{H}_{2} \mathrm{O}_{2} \\ 10 \mathrm{ml} & 0.1 \mathrm{M} \text { phosphate buffer pH 7.0 } \\ 7 \mathrm{ml} & 0.006 \mathrm{M} \mathrm{Na}_{2} \mathrm{~S}_{2} \mathrm{O}_{3} \mathrm{H}_{2} \mathrm{O} \\ 78 \mathrm{ml} & \mathrm{H}_{2} \mathrm{O}\end{array}$

(2)

$\begin{array}{ll}50 \mathrm{ml} & 0.09 \mathrm{M} \mathrm{KI} \\ 50 \mathrm{ml} & \mathrm{H}_{2} \mathrm{O}\end{array}$

Incubate in solution (A) at room temperature for 15-30 min. Pour off solution, rinse several times with water, then add solution (B); activity will appear as white bands on a dark 
blue background.

\section{Esterase (EST)}

$50 \mathrm{ml} \quad$ Stain buffer III

$5 \mathrm{ml} \quad 1 \%$-napthyl-acetate in 1:1 acetone:water

*150 mg Fast Blue BB salt or Fast Black

Incubate at room temperature. Colour comes up quickly.

\section{General protein (GP).}

$5 \mathrm{~g} \quad$ Coomassie Brilliant Blue

$100 \mathrm{ml} \quad$ Destain solution (5:1:5 methanol:acetic:water)

Incubate at room temperature. Rinse several times with destain solution.

6. Glucose-6-phosphate dehydrogenase (GD).

$50 \mathrm{ml} \quad$ Stain buffer II

$200 \mathrm{mg} \quad$ Glucose-6-phosphate

$* 5 \mathrm{mg} \quad$ NADP

$* 10 \mathrm{mg} \quad$ NBT

$* 5 \mathrm{mg} \quad$ PMS

*10 mg $\quad \mathrm{MgCl}_{2}$

Incubate at $37^{\circ} \mathrm{C}$.

7. Glucose Phosphate isomerase (GPI)

$\begin{array}{ll}50 \mathrm{ml} & \text { Stain buffer III } \\ 25 \mathrm{mg} & \text { Na-Fructose-6-phosphate } \\ * 10 \mathrm{\mu} & \text { G6PDH } \\ * 5 \mathrm{mg} & \text { NADP } \\ * 10 \mathrm{mg} & \text { NBT } \\ * 5 \mathrm{mg} & \text { PMS }\end{array}$


$* 10 \mathrm{mg} \quad \mathrm{MgCl}_{2}$

Incubate at $37^{\circ} \mathrm{C}$.

8. Glyceraldehyde-phosphate dehydrogenase (GAPDH)

$\begin{array}{ll}50 \mathrm{ml} & \text { Stain Buffer II } \\ 270 \mathrm{mg} & \text { Fructose-1,6-diphosphate } \\ 75 \mathrm{mg} & \text { Arsenic acid } \\ * 100 \mu & \text { ALD } \\ * 5 \mathrm{mg} & \text { NAD } \\ * 10 \mathrm{mg} & \text { NBT } \\ * 5 \mathrm{mg} & \text { PMS }\end{array}$

Incubate at $37^{\circ} \mathrm{C}$.

9. Glyceral-3-phosphate dehydrogenase (GPD)

$\begin{array}{ll}40 \mathrm{ml} & \text { Stain buffer II } \\ 1 \mathrm{~g} & \text { Glycerophosphate } \\ 400 \mathrm{mg} & \text { Pyruvic acid } \\ * 20 \mathrm{mg} & \text { NAD } \\ * 5 \mathrm{mg} & \text { MTT } \\ * 5 \mathrm{mg} & \text { PMS }\end{array}$

Incubate at $37^{\circ} \mathrm{C}$.

10. Lactate dehydrogenase (LDH)

$\begin{array}{ll}50 \mathrm{ml} & \text { Stain buffer III } \\ 25 \mathrm{ml} & 0.5 \mathrm{M} \text { DL-Na-lactic acid } \\ * 5 \mathrm{mg} & \text { NAD } \\ * 10 \mathrm{mg} & \text { NBT } \\ * 5 \mathrm{mg} & \text { PMS }\end{array}$


Incubate at $37^{\circ} \mathrm{C}$.

11. Malate dehydrogenase (MDH)

$\begin{array}{ll}50 \mathrm{ml} & \text { Stain buffer III } \\ 25 \mathrm{ml} & 0.5 \mathrm{M} \text { DL-Na-malate } \mathrm{pH} 7.0 \\ * 5 \mathrm{mg} & \text { NAD } \\ * 10 \mathrm{mg} & \text { NBT } \\ * 5 \mathrm{mg} & \text { PMS }\end{array}$

Incubate at $37^{\circ} \mathrm{C}$.

12. Mannose phosphate isomerase (MPI)

$\begin{array}{ll}50 \mathrm{ml} & \text { Stain buffer II } \\ 50 \mathrm{mg} & \text { Ba-mannose-6-phosphate } \\ * 100 \mu & \text { PGI } \\ * 80 \mu & \text { G6PDH } \\ * 5 \mathrm{mg} & \text { NADP } \\ * 10 \mathrm{mg} & \text { NBT } \\ * 5 \mathrm{mg} & \text { PMS } \\ * 10 \mathrm{mg} & \mathrm{MgCl}_{2}\end{array}$

Incubate at $37^{\circ} \mathrm{C}$.

\section{Peptidase (PEP)}

$\begin{array}{ll}50 \mathrm{ml} & \text { Stain buffer II } \\ * 50 \mathrm{mg} & \text { O-dianisidine } \\ * 80 \mathrm{mg} & \text { L-leucyl-L-alanine } \\ * 80 \mathrm{mg} & \text { L-phenylalanine-L-proline } \\ * 80 \mathrm{mg} & \text { L-leucyl-L-tyrosine } \\ * 80 \mathrm{mg} & \text { L-leucylglycyl-glycine } \\ * 10 \mathrm{mg} & \text { Amino acid oxidase (snake venom) } \\ * 500 \mu & \text { Peroxidase }\end{array}$


$50 \mathrm{mg} \quad \mathrm{MgCl}_{2}$

Incubate at $37^{\circ} \mathrm{C}$.

14. Phosphogluconate dehydrogenase (PGD)

$50 \mathrm{ml} \quad$ Stain buffer II

$100 \mathrm{mg} \quad$ Ba-6-phosphogluconic acid

*5 mg NADP

$* 10 \mathrm{mg} \quad$ NBT

*5 mg PMS

*10 mg $\quad \mathrm{MgCl}_{2}$

Incubate at $37^{\circ} \mathrm{C}$.

\section{Phosphoglucomutase (PGM)}

$\begin{array}{ll}50 \mathrm{ml} & \text { Stain buffer II } \\ 100 \mathrm{mg} & \text { K-glucose-1-phosphate } \\ * 50 \mu & \text { G6PDH } \\ * 5 \text { drops } & \text {-D-glucose-1,6-diphosphate } \\ * 5 \mathrm{mg} & \text { NADP } \\ * 10 \mathrm{mg} & \text { NBT } \\ * 5 \mathrm{mg} & \mathrm{PMS} \\ * 10 \mathrm{mg} & \mathrm{MgCl}_{2}\end{array}$

Incubate at $37^{\circ} \mathrm{C}$.

16. Peroxidase (POX)

$\begin{array}{ll}* 50 \mathrm{mg} & \text { 3-amino-9-ethyl-carbazol } \\ * 5 \mathrm{ml} & \text { Dimethyl formamide } \\ 50 \mathrm{ml} & 0.05 \mathrm{M} \mathrm{Na} \text { acetate, } \mathrm{pH} 5.0 \\ 0.5 \mathrm{ml} & 3 \% \text { Peroxide - add after } 30 \text { mins. }\end{array}$


* Dissolve first, incubate cold.

Incubate at room temperature. Rinse in water. Fix in 1:1 glycerol : water

17. Superoxide dismutase (SOD)

$50 \mathrm{ml} \quad$ Stain buffer

$* 10 \mathrm{mg} \quad \mathrm{NBT}$

*5 mg PMS

After incubate at $37^{\circ} \mathrm{C}$ it shows up as white bands.

* = active component, add immediately before development 


\section{Common stain components}

Destain solution $=5: 1: 5$ methanol $:$ acetic acid $:$ distilled water

EDTA $=$ Ethylenediaminetetra-acetic acid

$\mathrm{MgCl}_{2}=$ Magnesium chloride

MTT $=$ Methyl thiazolyl tetrazolium

$\mathrm{NAD}=\mathrm{B}-\mathrm{Nicotinamide}$ adenine dinucleotide

NADP $=$ B-Nicotinamide adenine dinucleotide phosphate

PMS = Phenazine methosulphate

\section{Stain Buffers and components}

Stain Buffer

I

II

III
Components

$24.2 \mathrm{~g}$ Tris $\mathrm{l}^{-1} \mathrm{pH} 8.0$

$100 \mathrm{ml}$ Stain Buffer I, diluted to $500 \mathrm{ml}$

with distilled water

Ridgeway Gel Buffer 
Appendix 7. Photographs of electrophoretic banding patterns of Gracilaria sordida proteins to show examples of the kind of resolution and variation stained in typical gels. a. GAPDH b. GD (G6PDH). Throughout : Upper gel: TG buffer. Lower gel: TEB buffer.

- GAPDH R.20

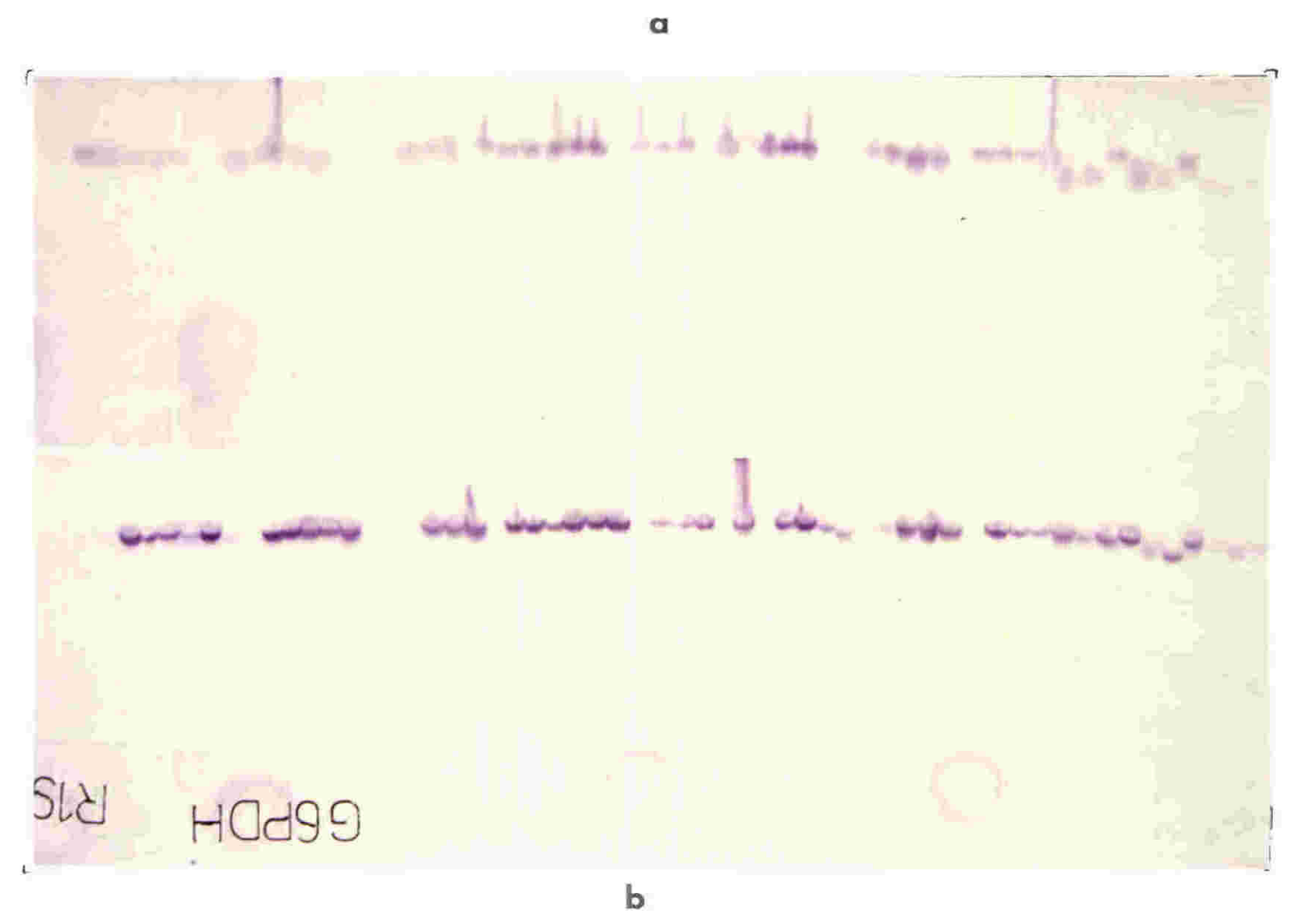


Appendix 7. Continued c. GP d. Fluorescent Protein (FP)

GP

$\mathrm{R} 20$
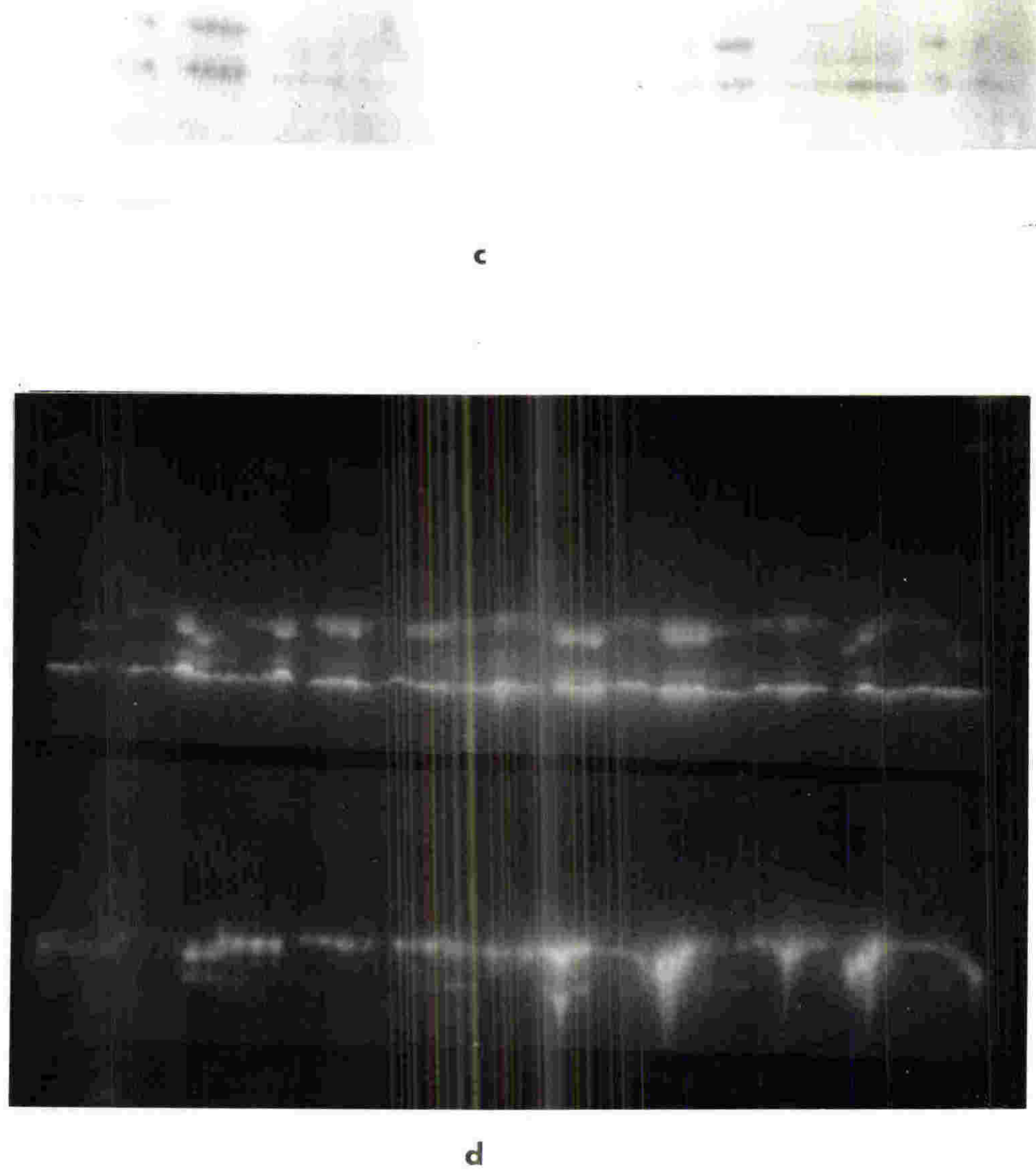
Appendix 7. Continued e. LDH f. PEP 
Appendix 7. Continued g. PGI h. PGM

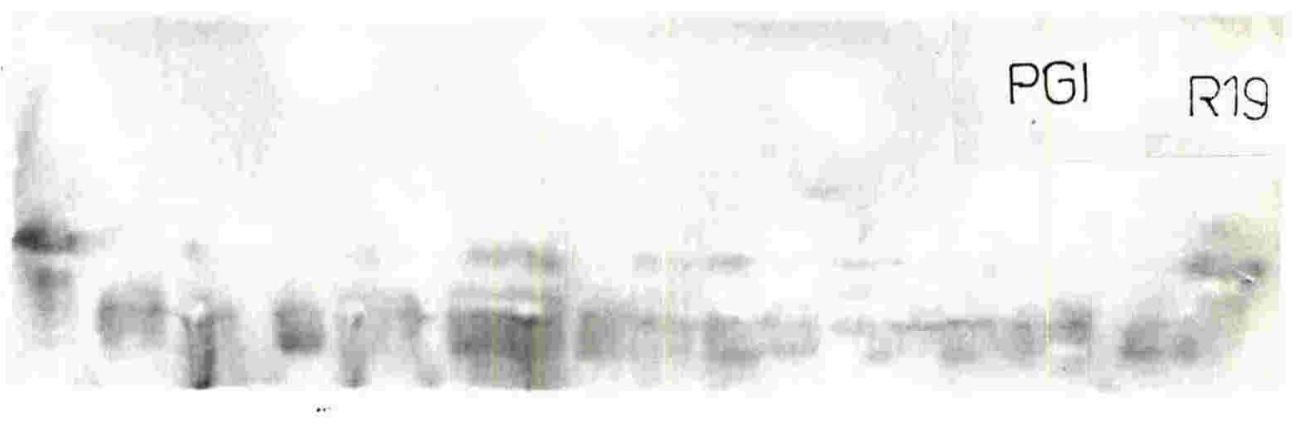

es

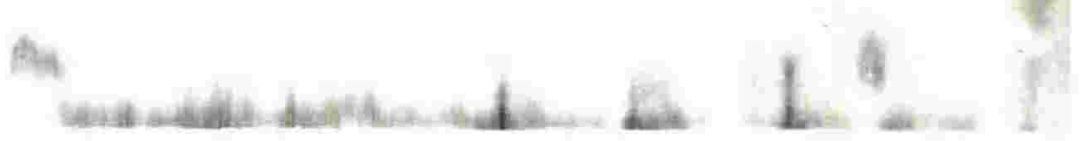

g

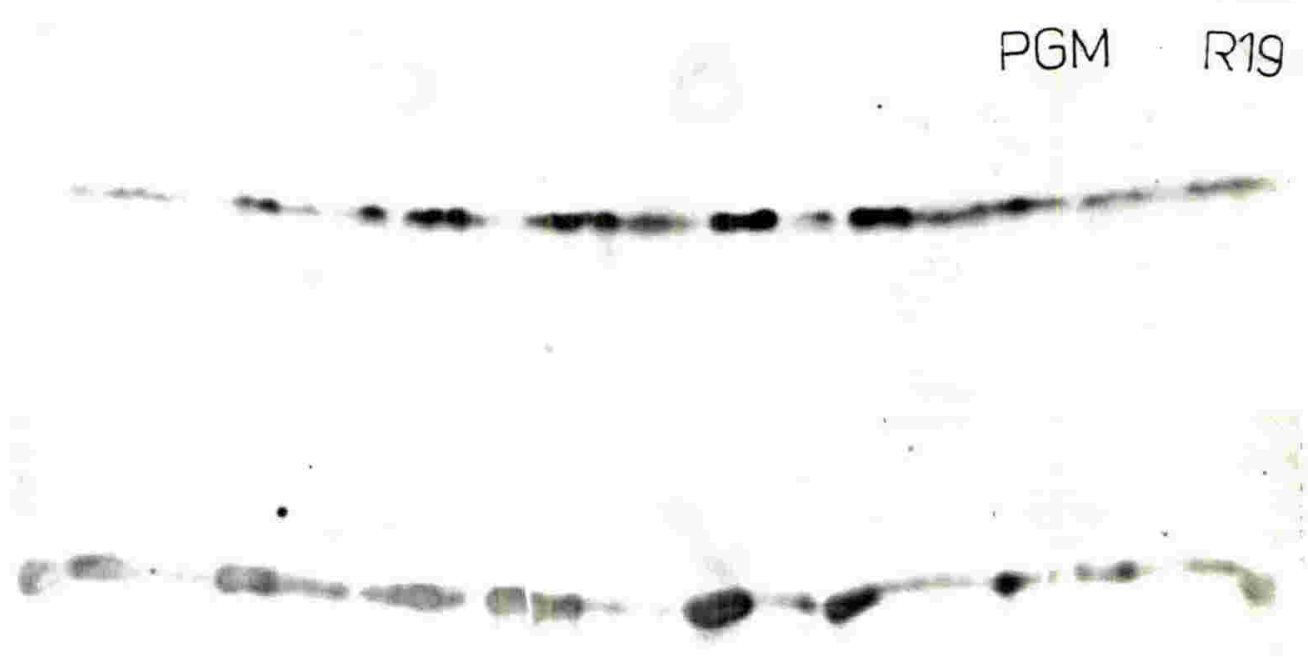


Appendix 8. Details of the Gracilaria sordida. collecting sites and habit details of typical plants.
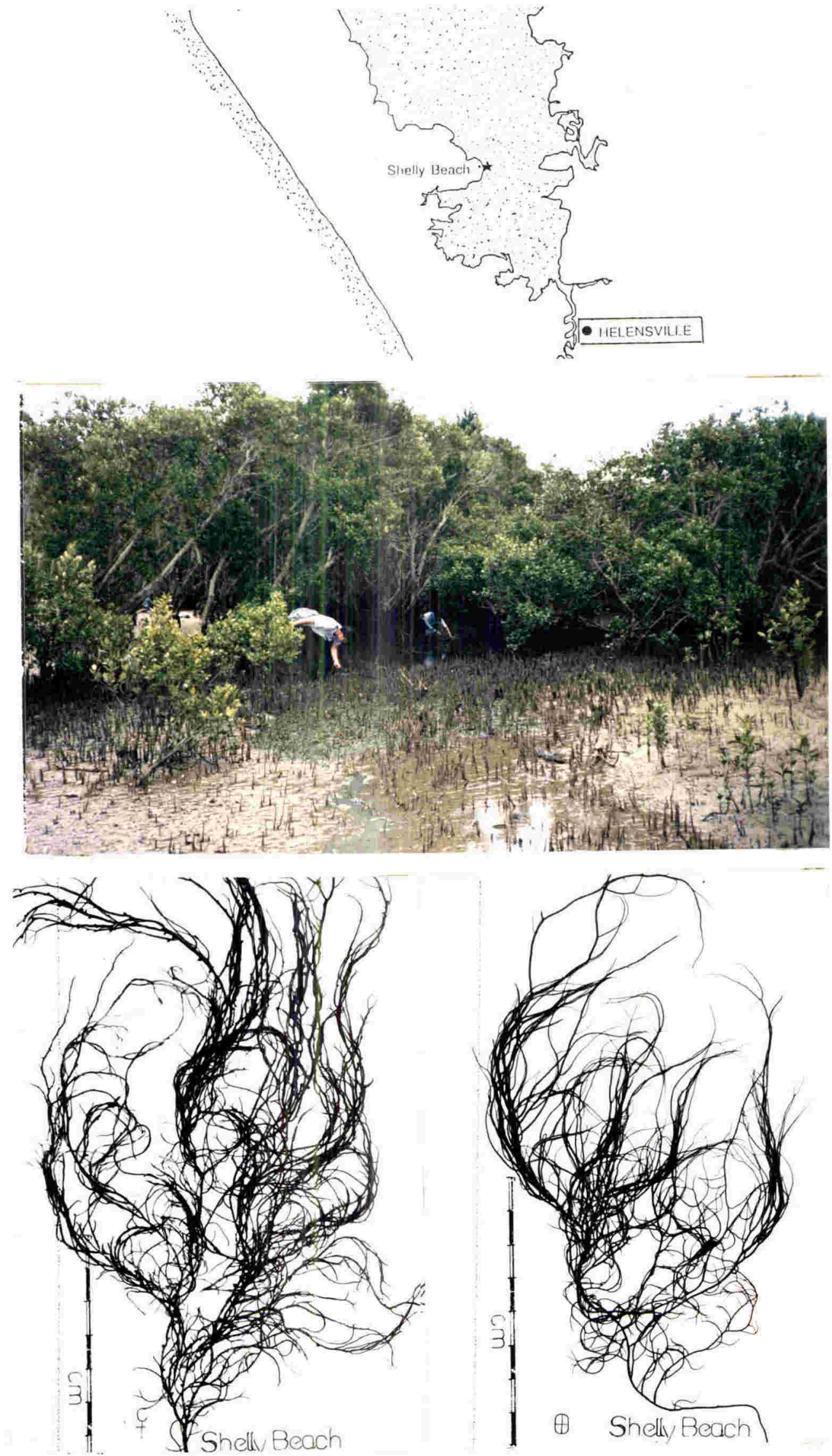

8.1. Collecting site and habit of Gracilaria sordida at Shelly Beach, Kaipara Harbour. 

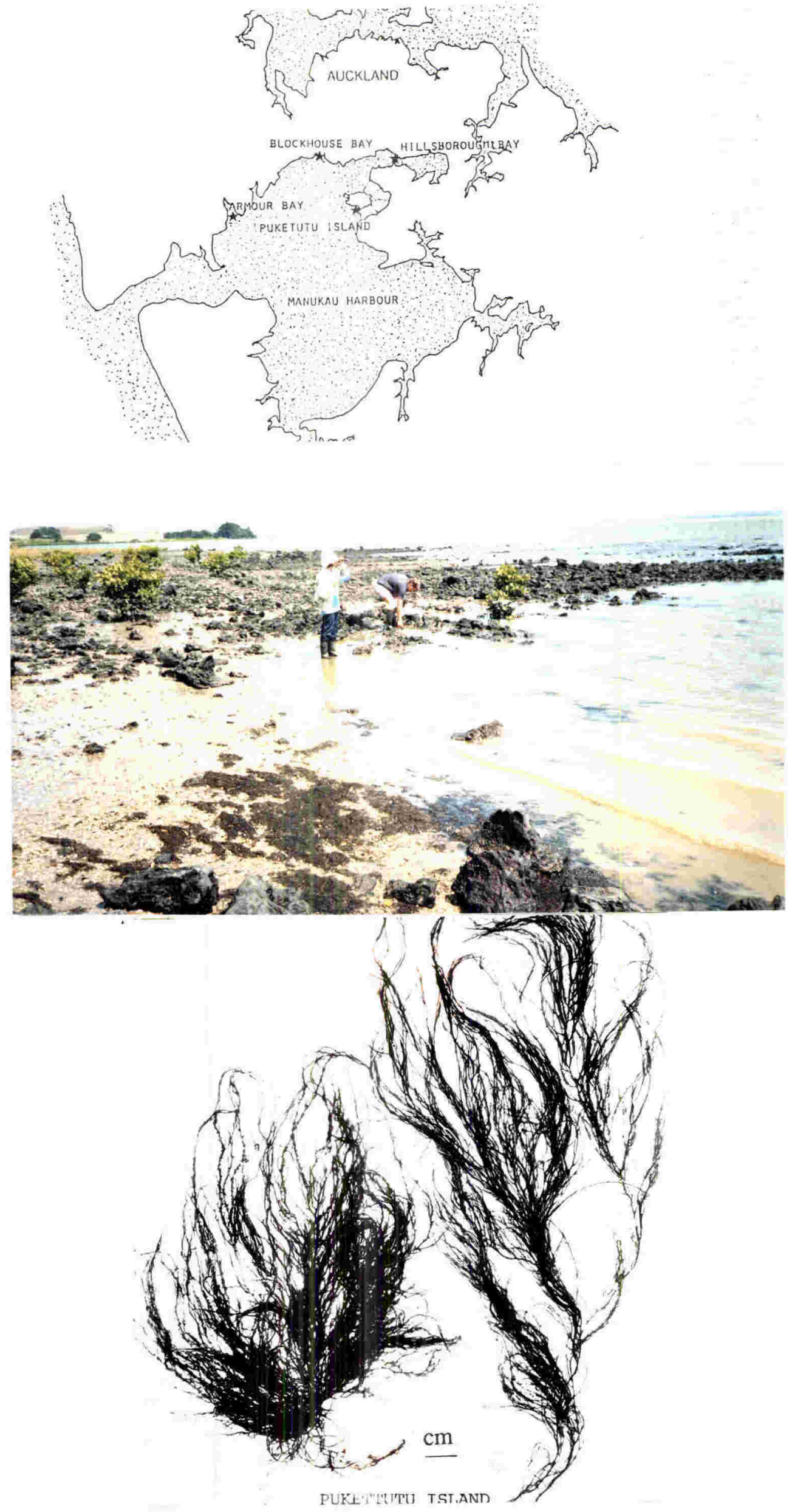

8.2. Collecting site and habit of Gracilaria sordida at Puketutu Island, Manukau Harbour. 


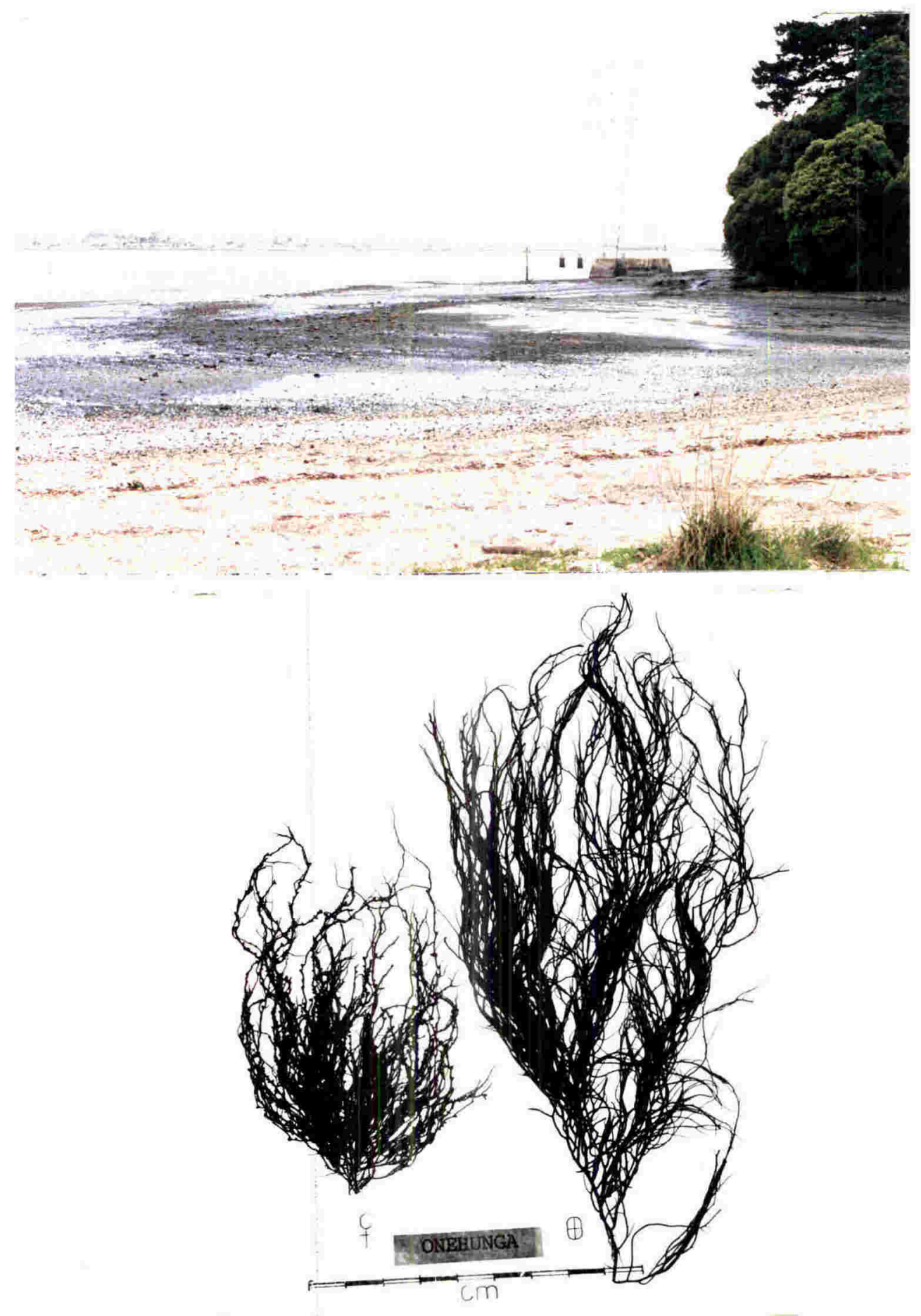

8.3. Collecting site and habit of Gracilaria sordida at Hillsborough Bay, Manukau Harbour. 

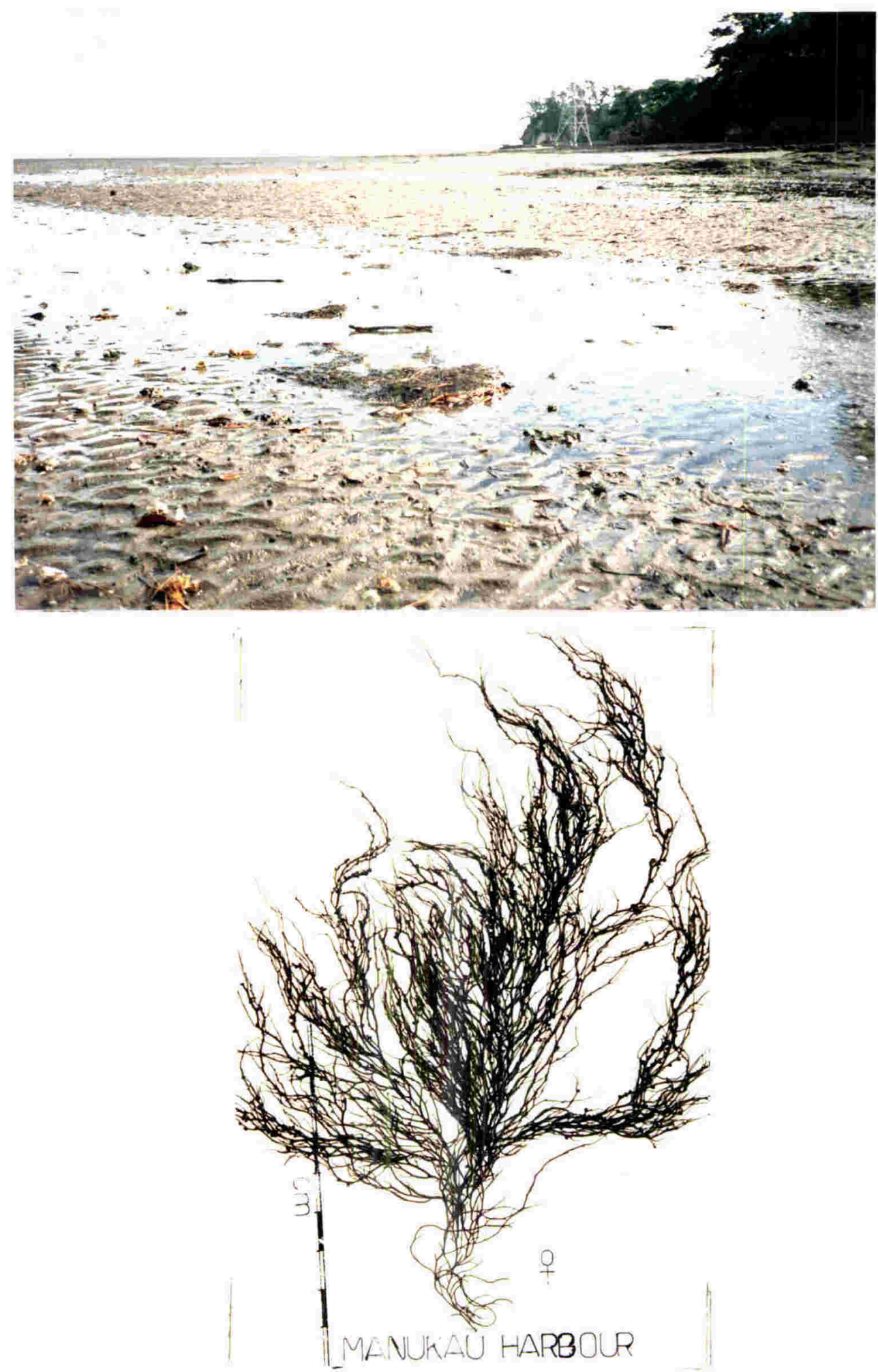

8.4. Collecting site and habit of Gracilaria sordida at Blockhouse Bay, Manukau Harbour. 


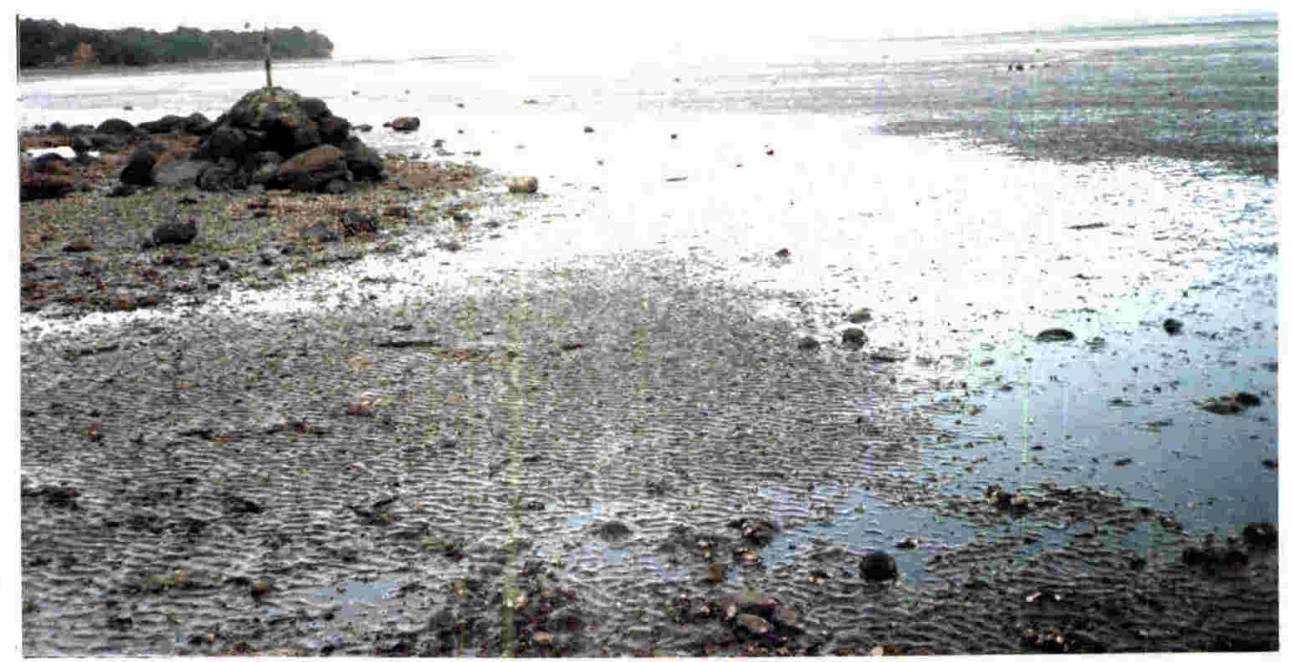

8.5. Collecting site of Gracilaria sordida at Armour Bay, Manukau Harbour. 

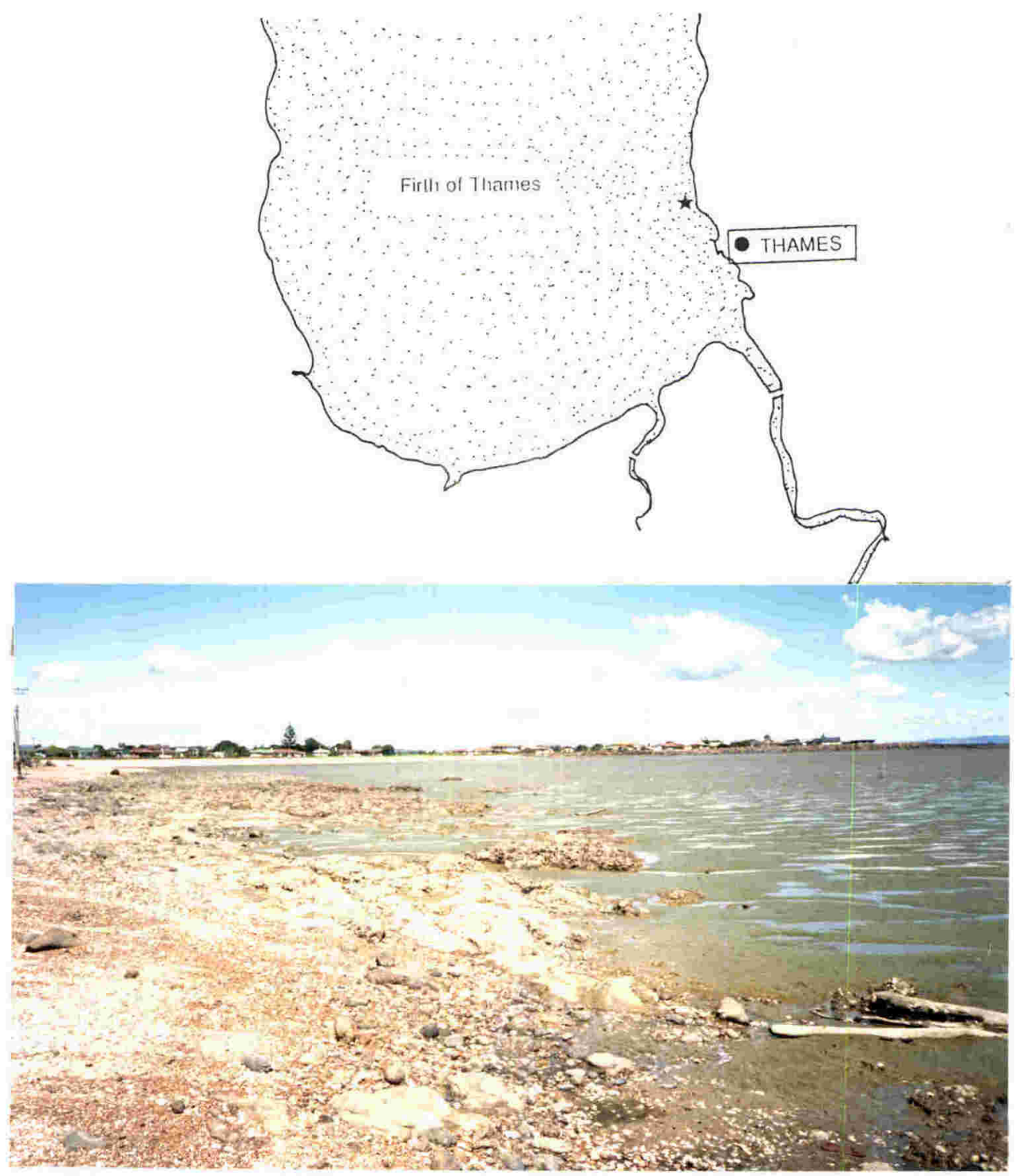

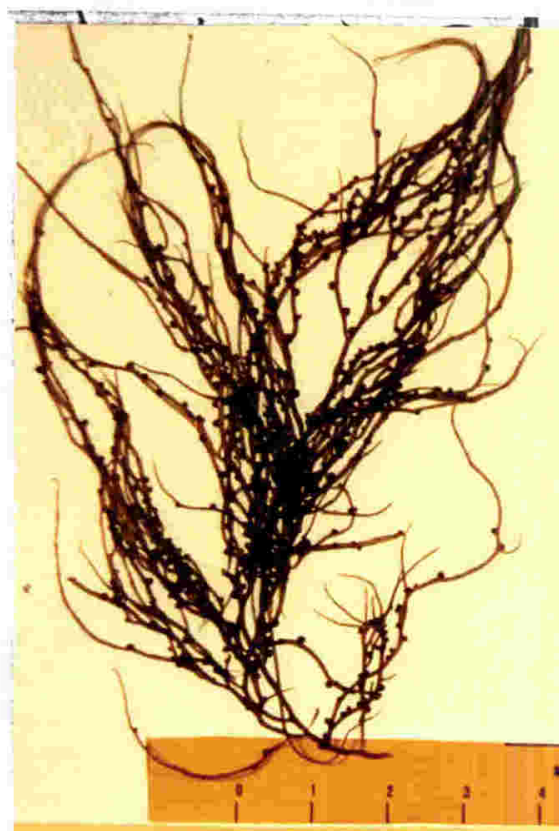

FEMALE GAMETOPHYTE

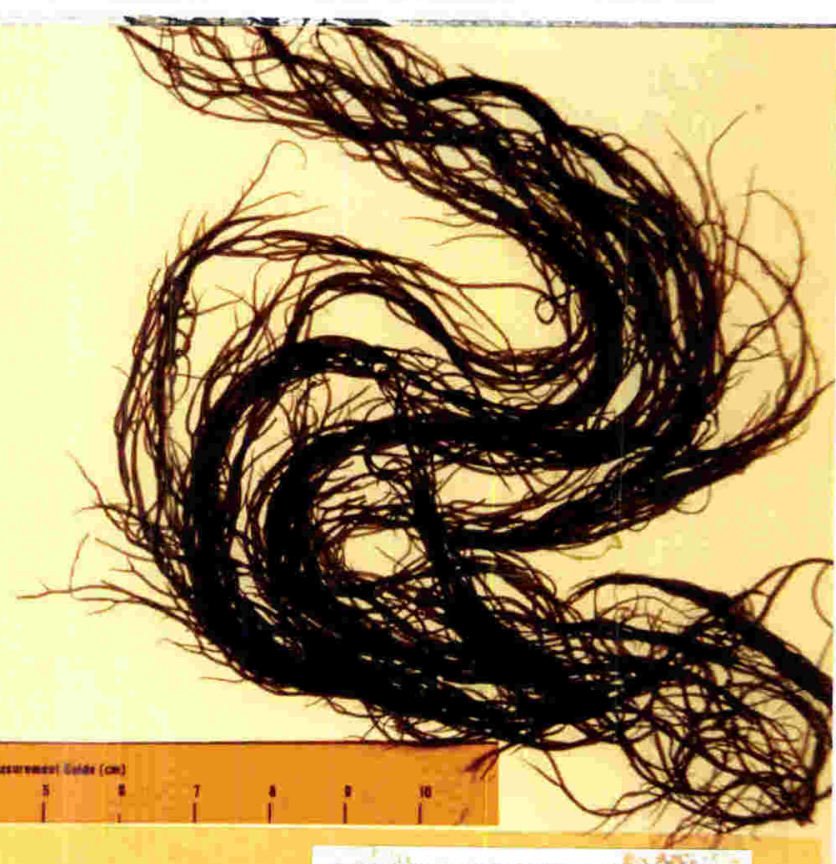

TETRASPOROPHYTE

\section{THAMES}

8.6. Collecting site and habit of Gracilaria sordida at Thames. 

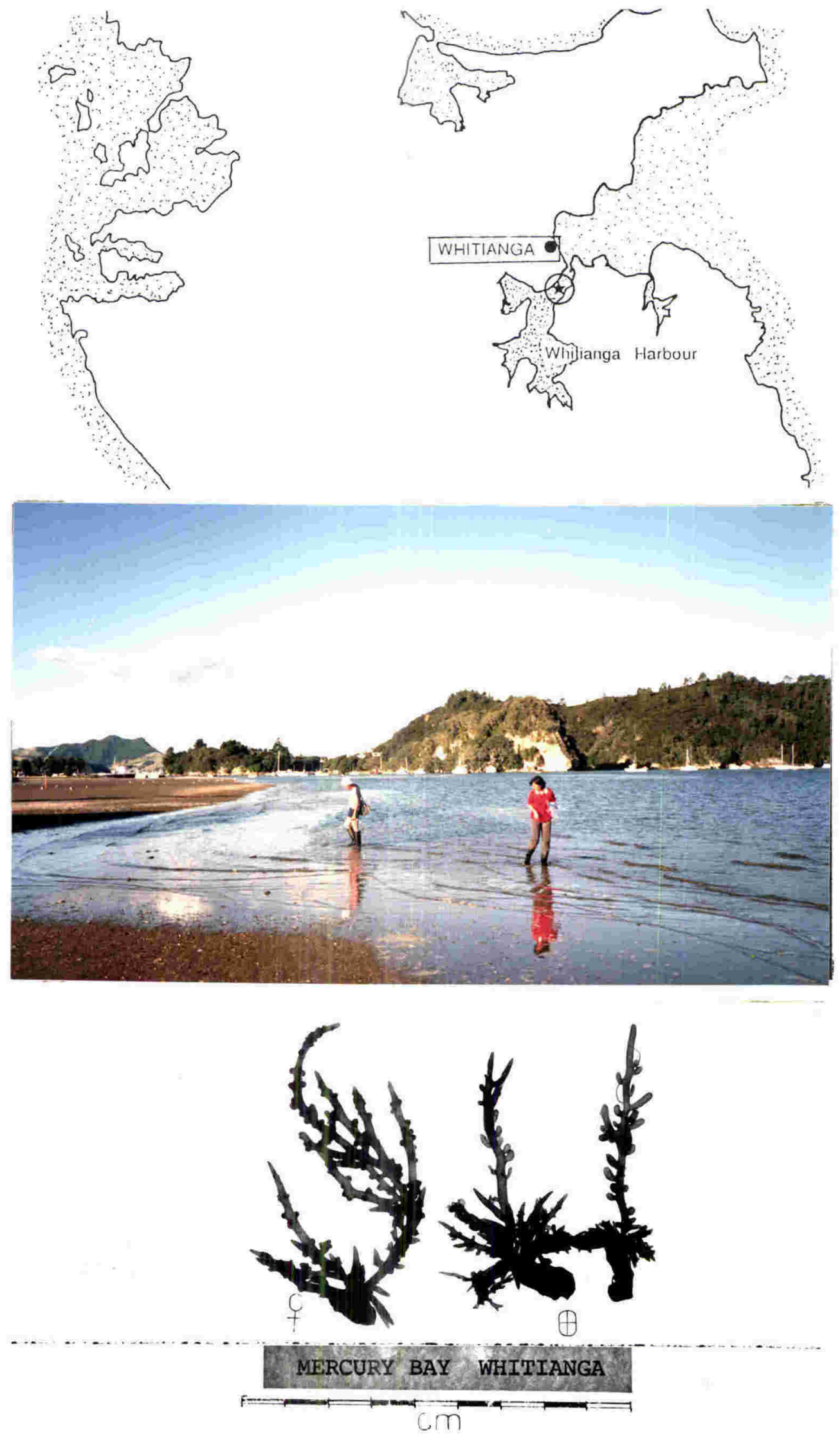

8.7. Collecting site and habit of Gracilaria sordida at Whitianga Harbour. 

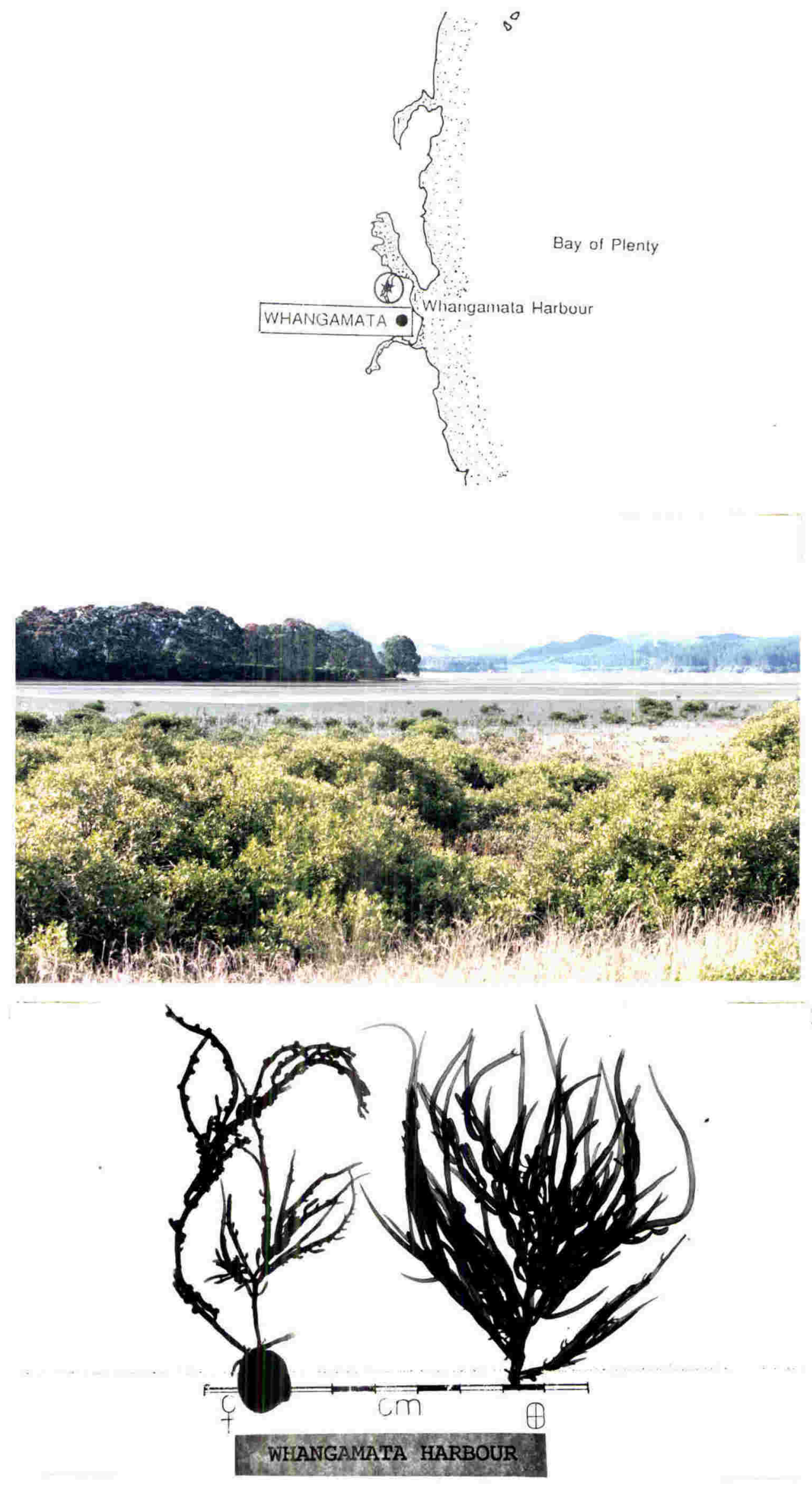

8.8. Collecting site and habit of Gracilaria sordida at Whangamata Harbour. 

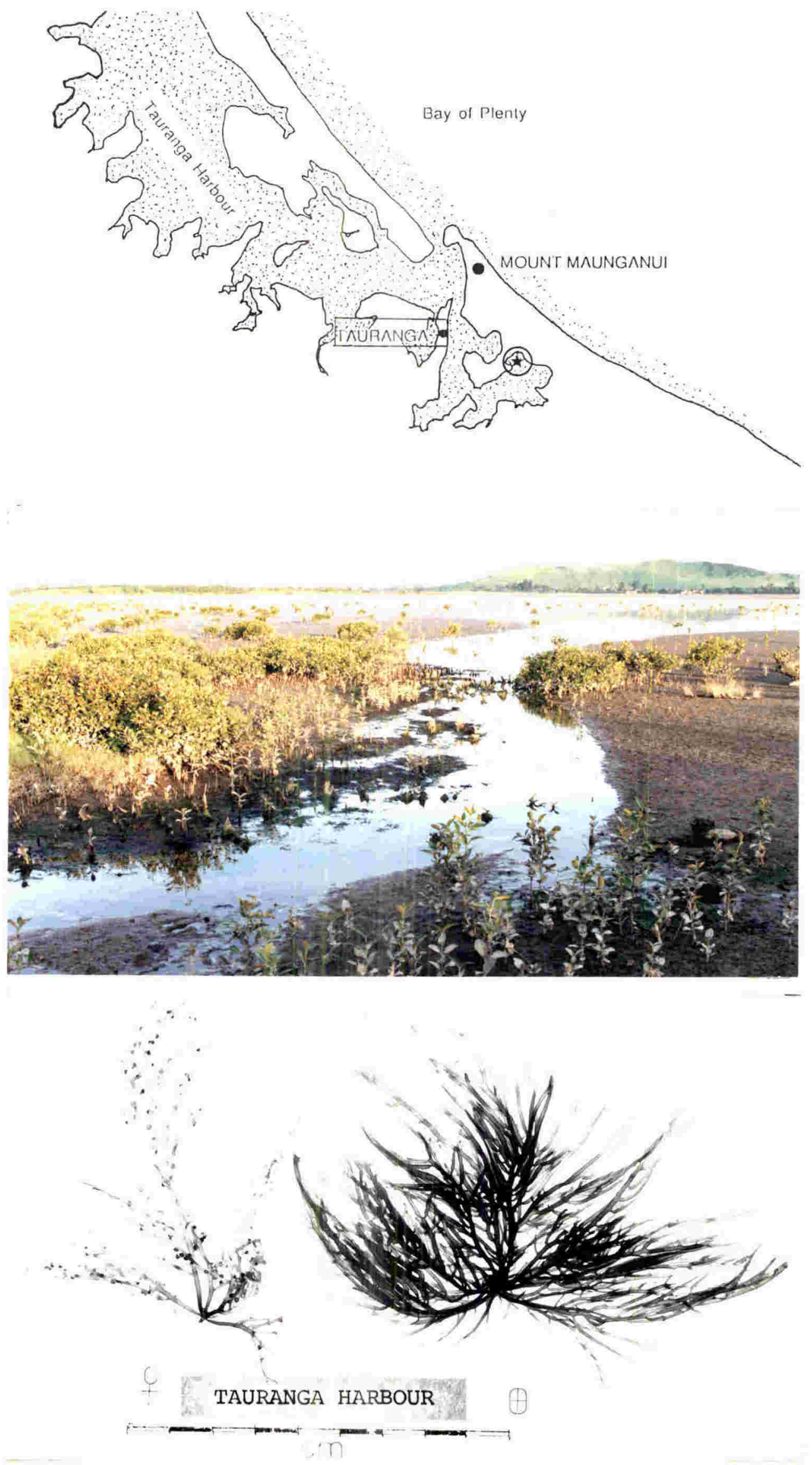

8.9. Collecting site and habit of Gracilaria sordida at Tauranga Harbour. 
Bay of Plenty
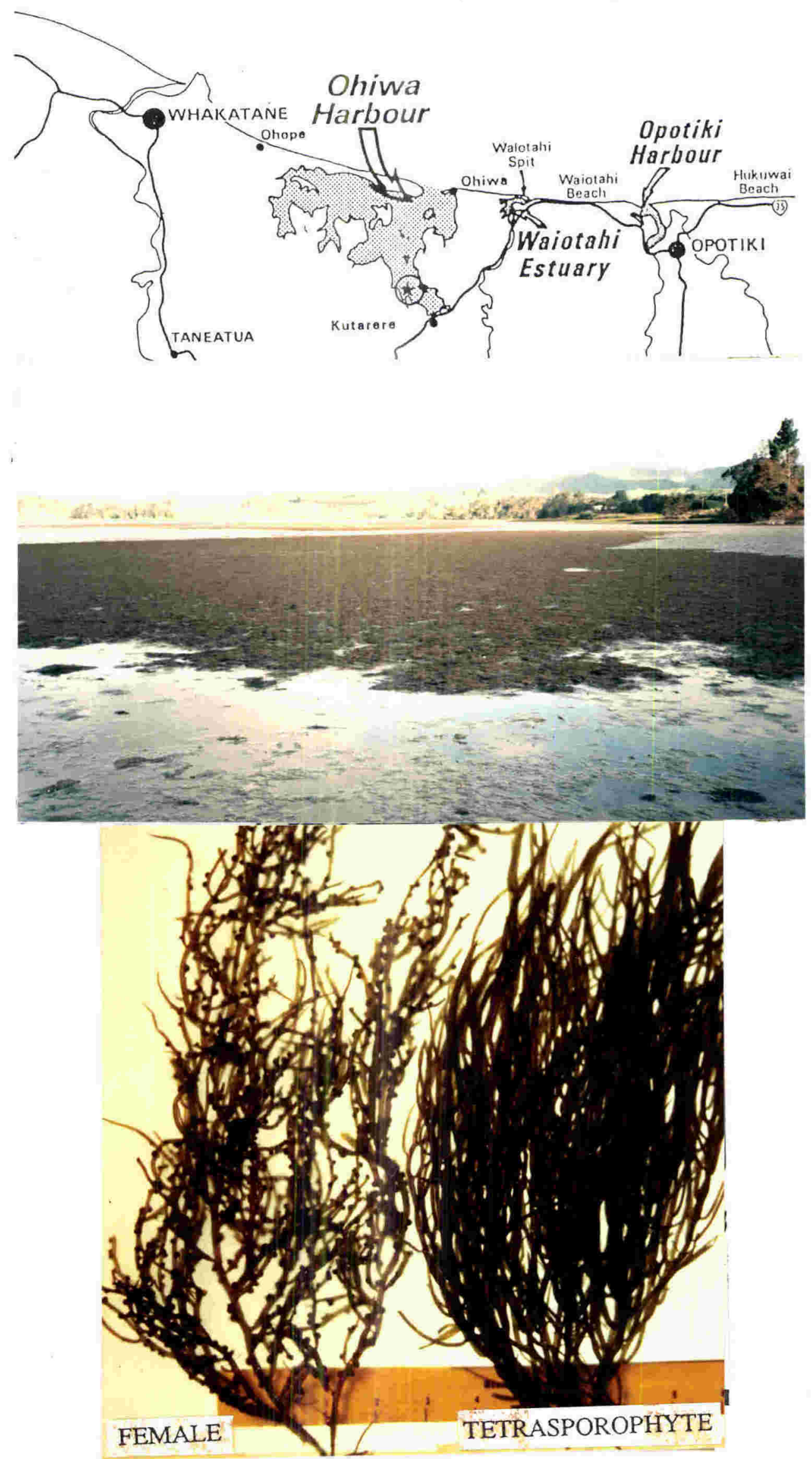

8.10. Collecting site and habit of Gracilaria sordida at Ohiwa Harbour. 

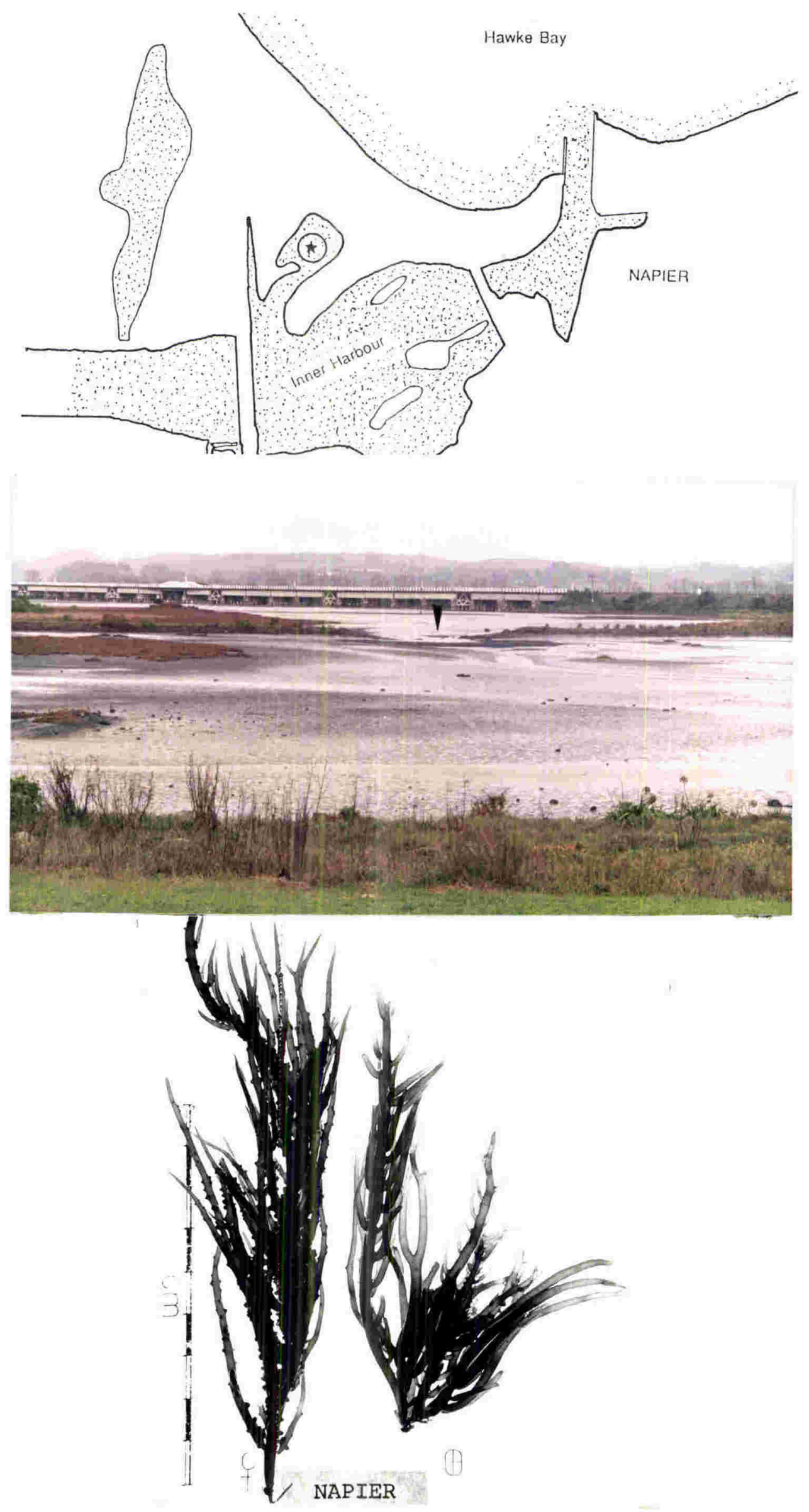

8.11. Collecting site and habit of Gracilaria sordida at Napier. 

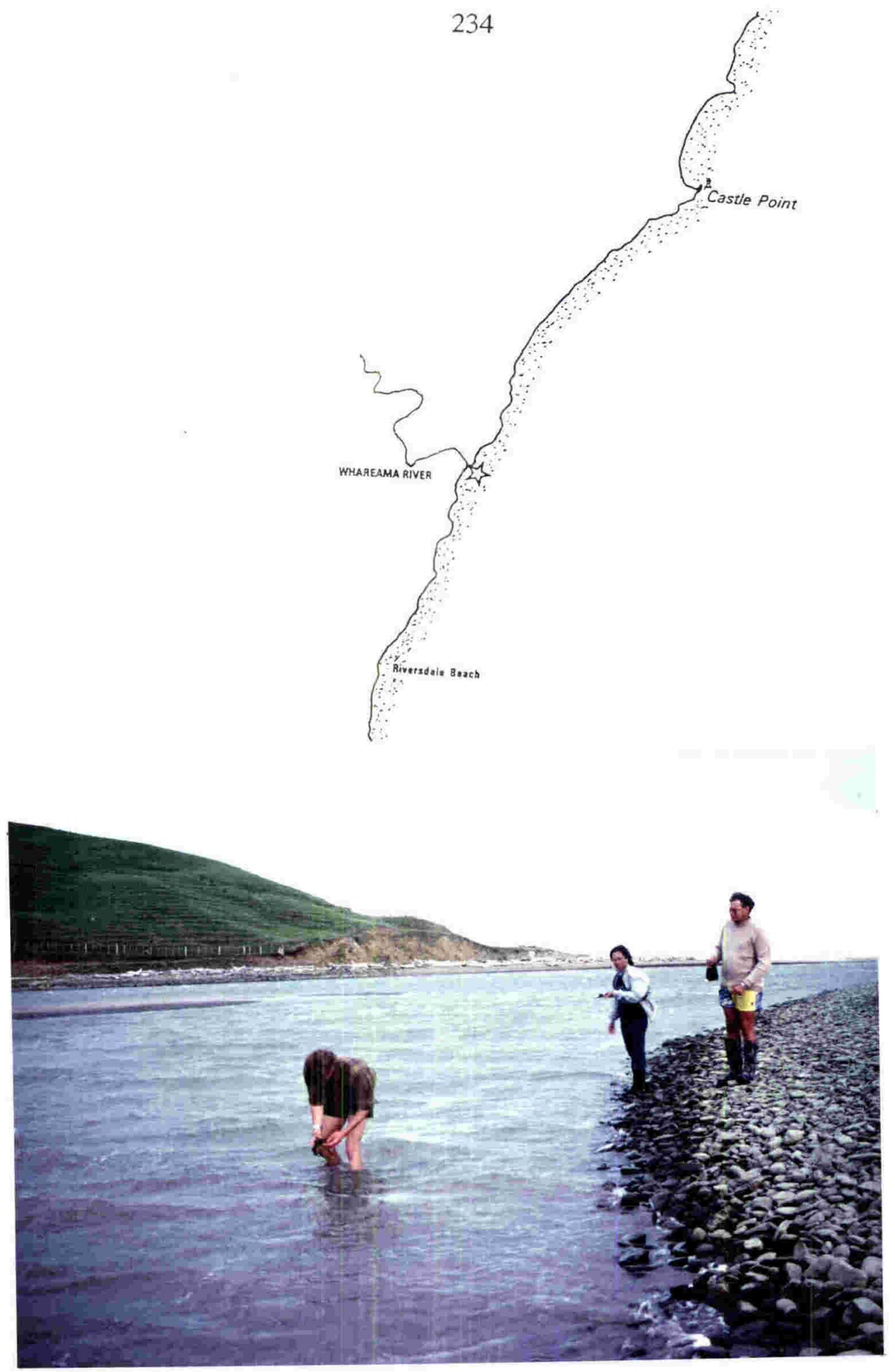

8.12. Collecting site and habit of Gracilaria sordida at Riversdale. 

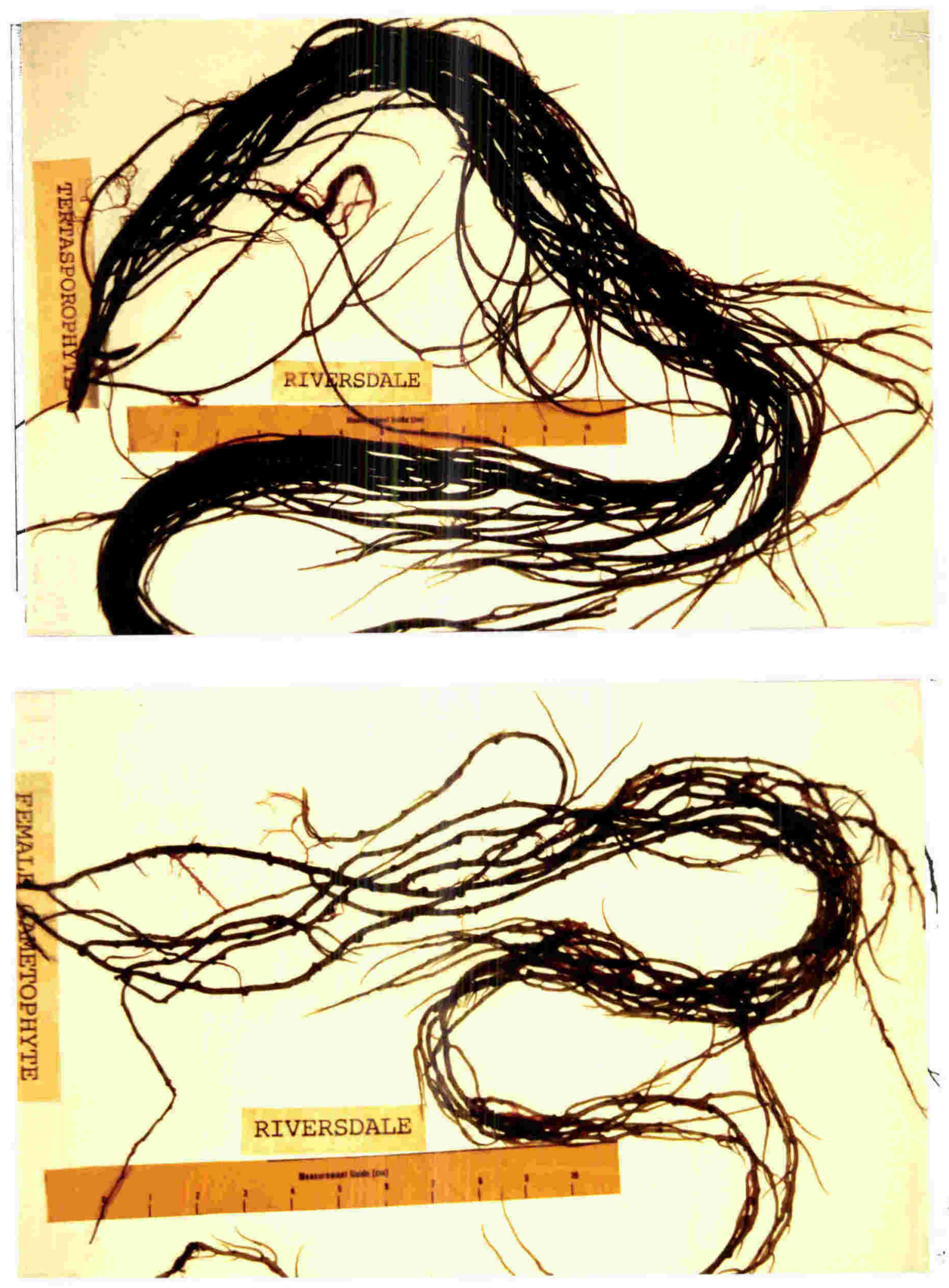

8.12. Collecting site and habit of Gracilaria sordida at Riversdale. 


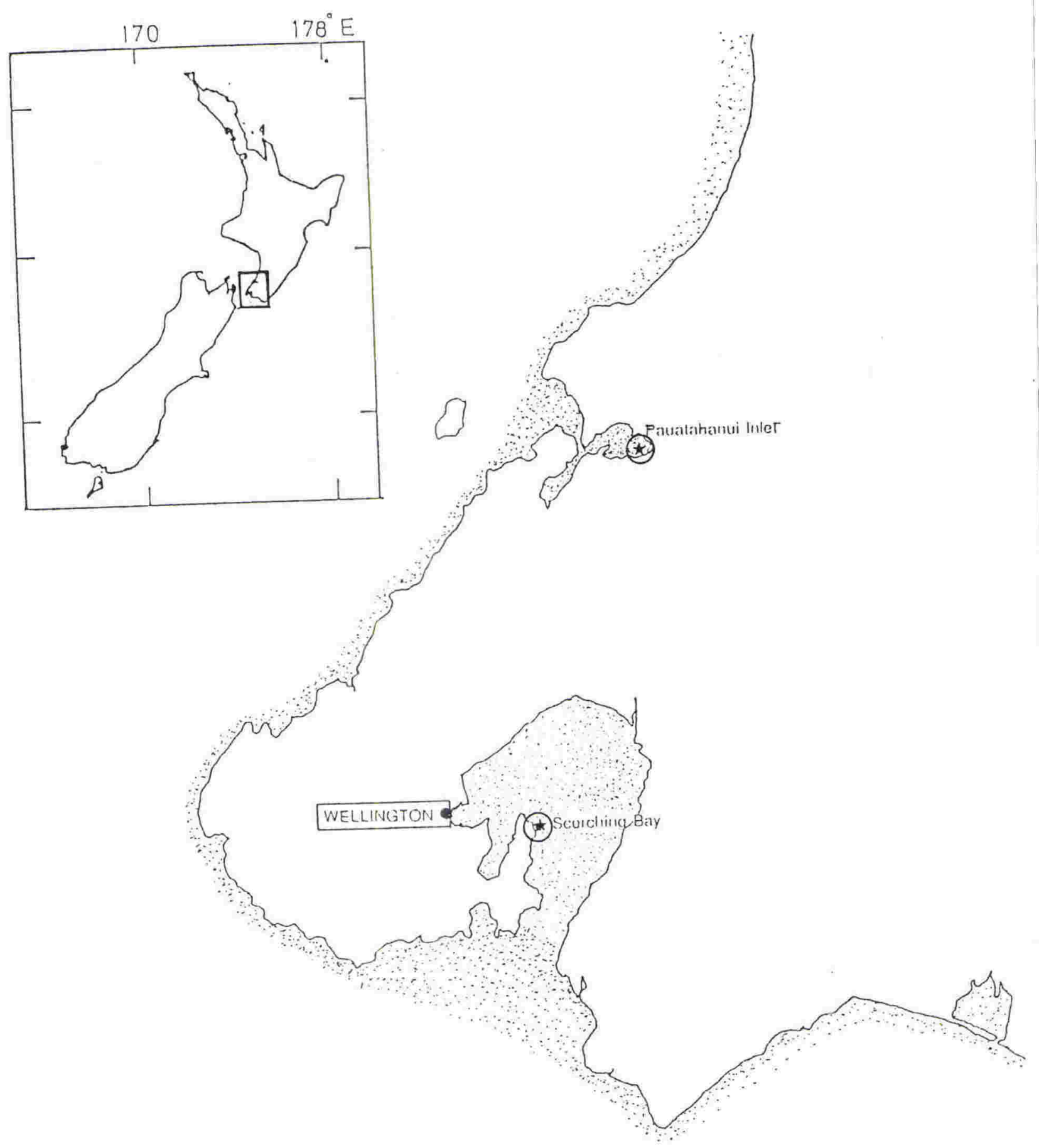

8.13. Collecting site and habit of Gracilaria sordida at Scorching Bay, and Pauatahanui Inlet, Wellington Harbour. 

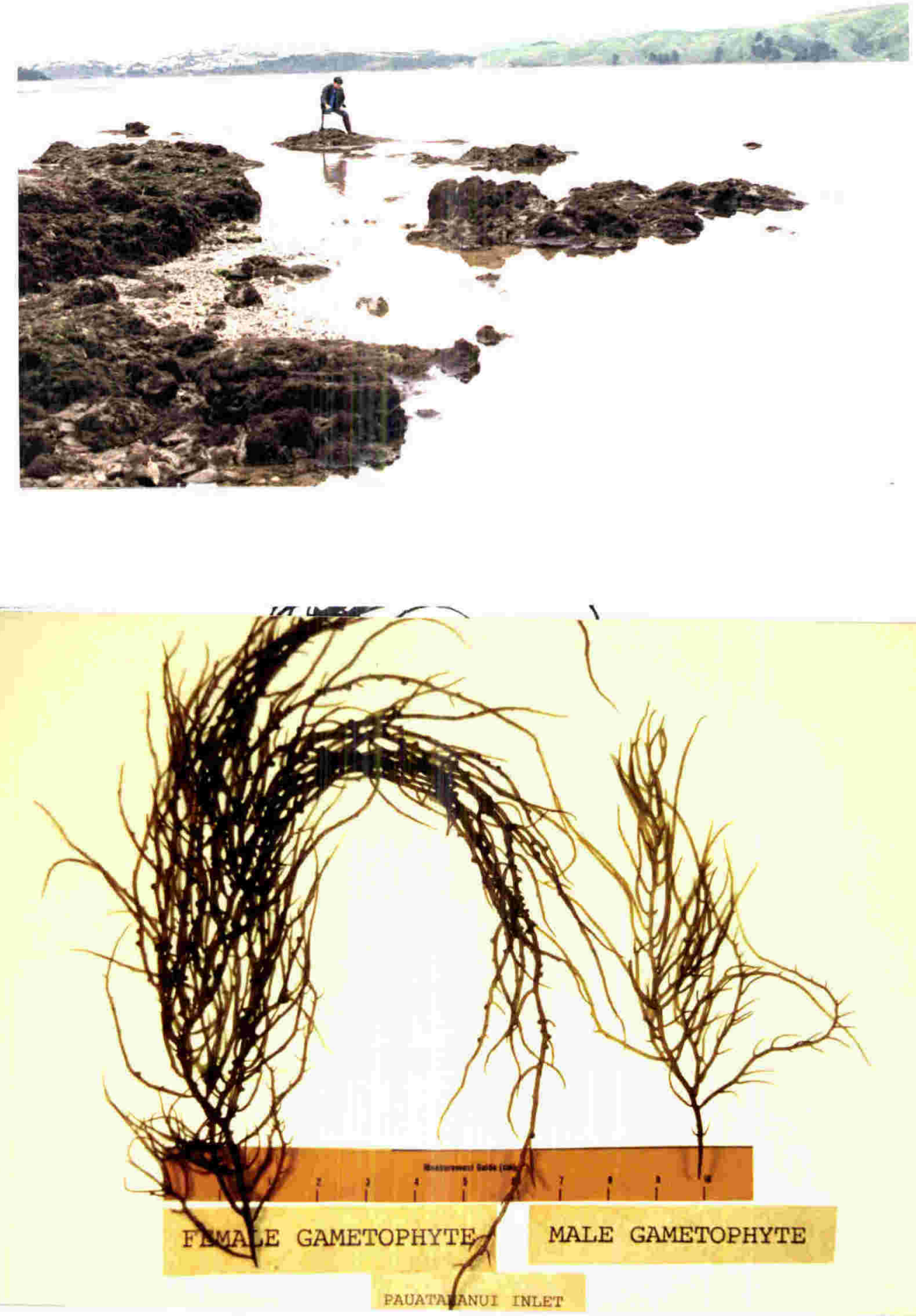

8.14. Collecting site and habit of Gracilaria sordida at Pauatahanui Inlet, Porirua Harbour, Wellington. 

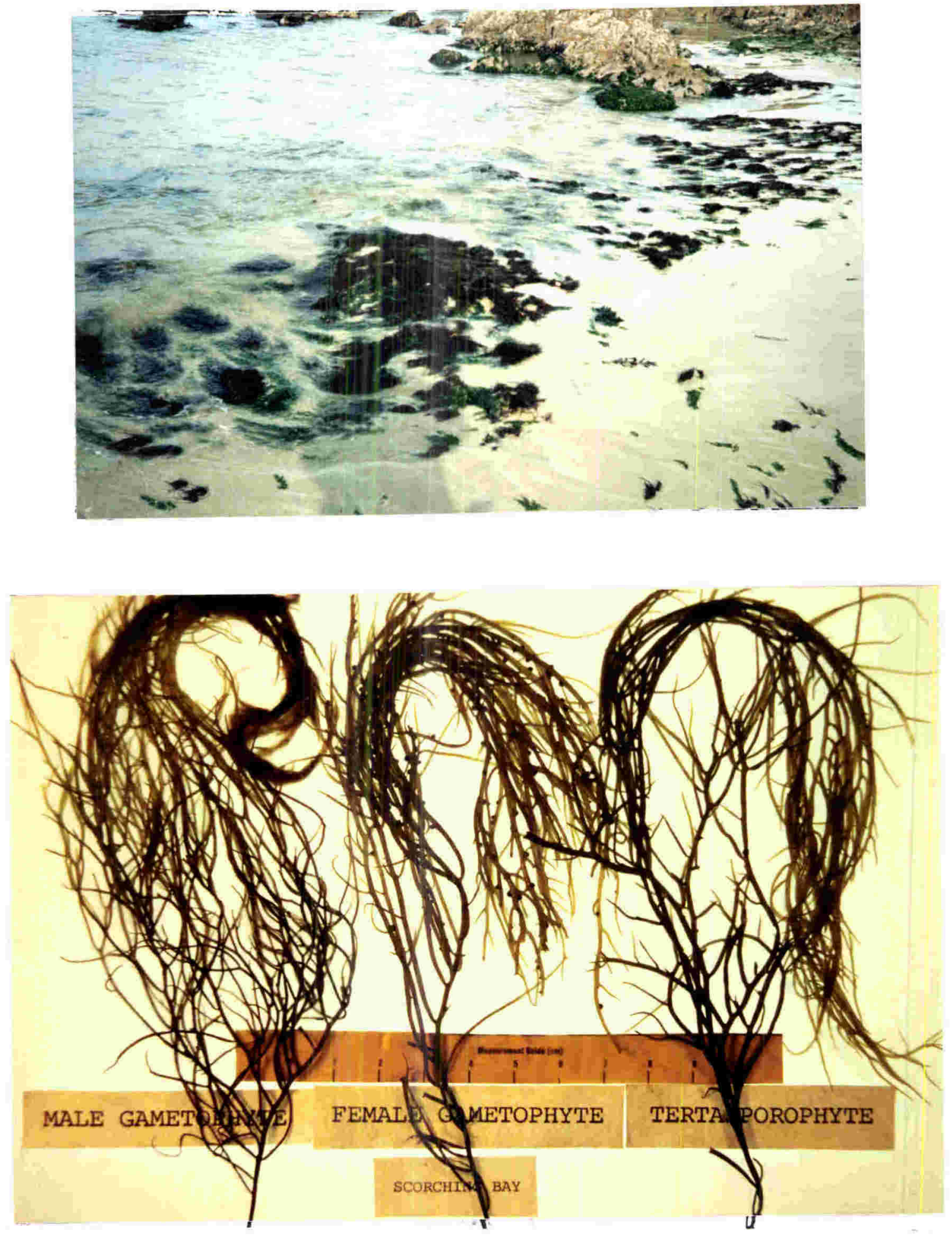

8.13. Collecting site and habit of Gracilaria sordida at Scorching Bay, Wellington Harbour. 


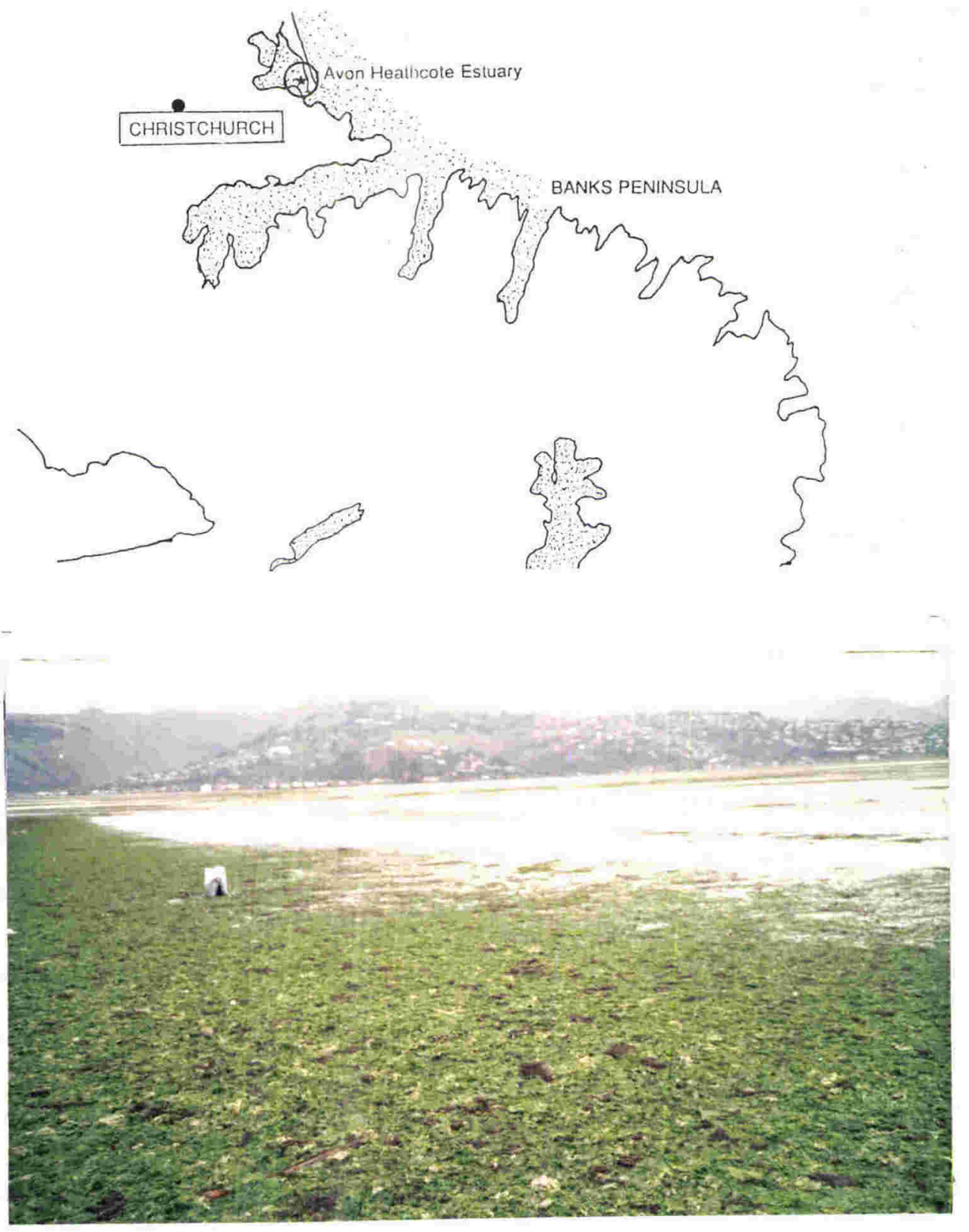

8.15. Collecting site of Gracilaria sordida at Avon-Heathcote Estuary, Christchurch. 

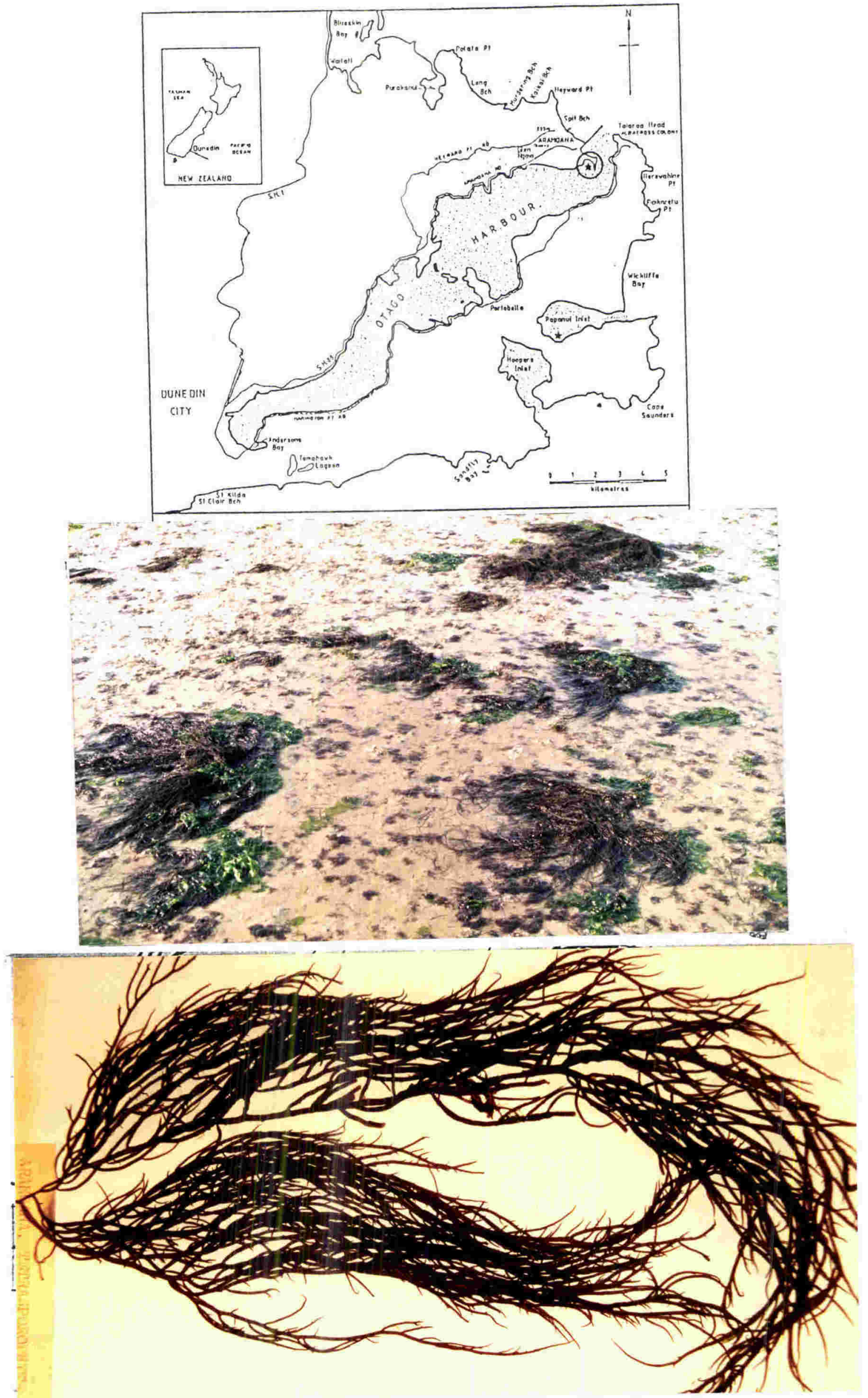

8.16. Collecting site and habit of Gracilaria sordida at Aramoana, Otago Harbour (and map of Papanui Inlet). 

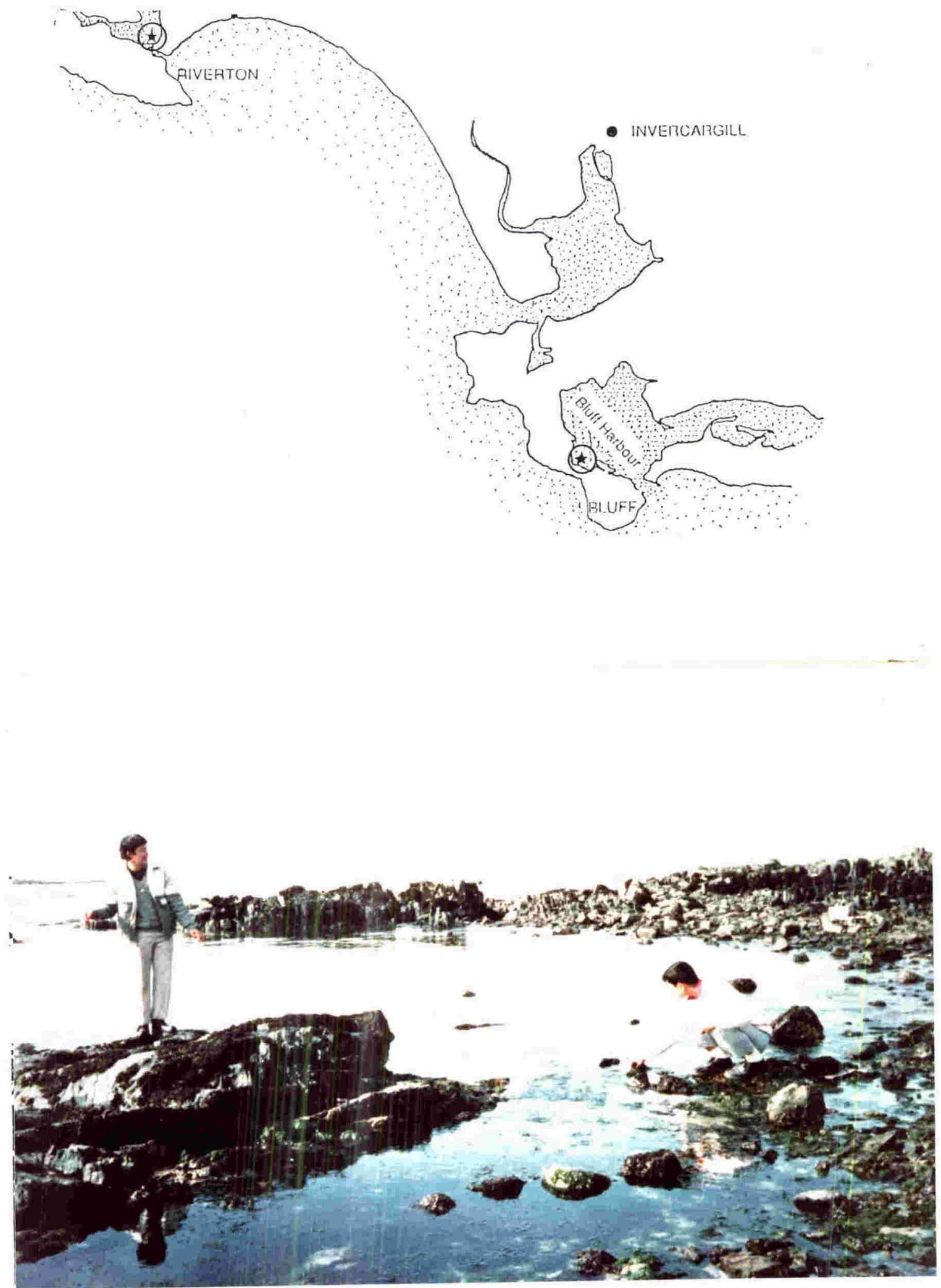

8.17. Collecting site of Gracilaria sordida at Bluff (and map of Riverton Harbour), Invercargill. 


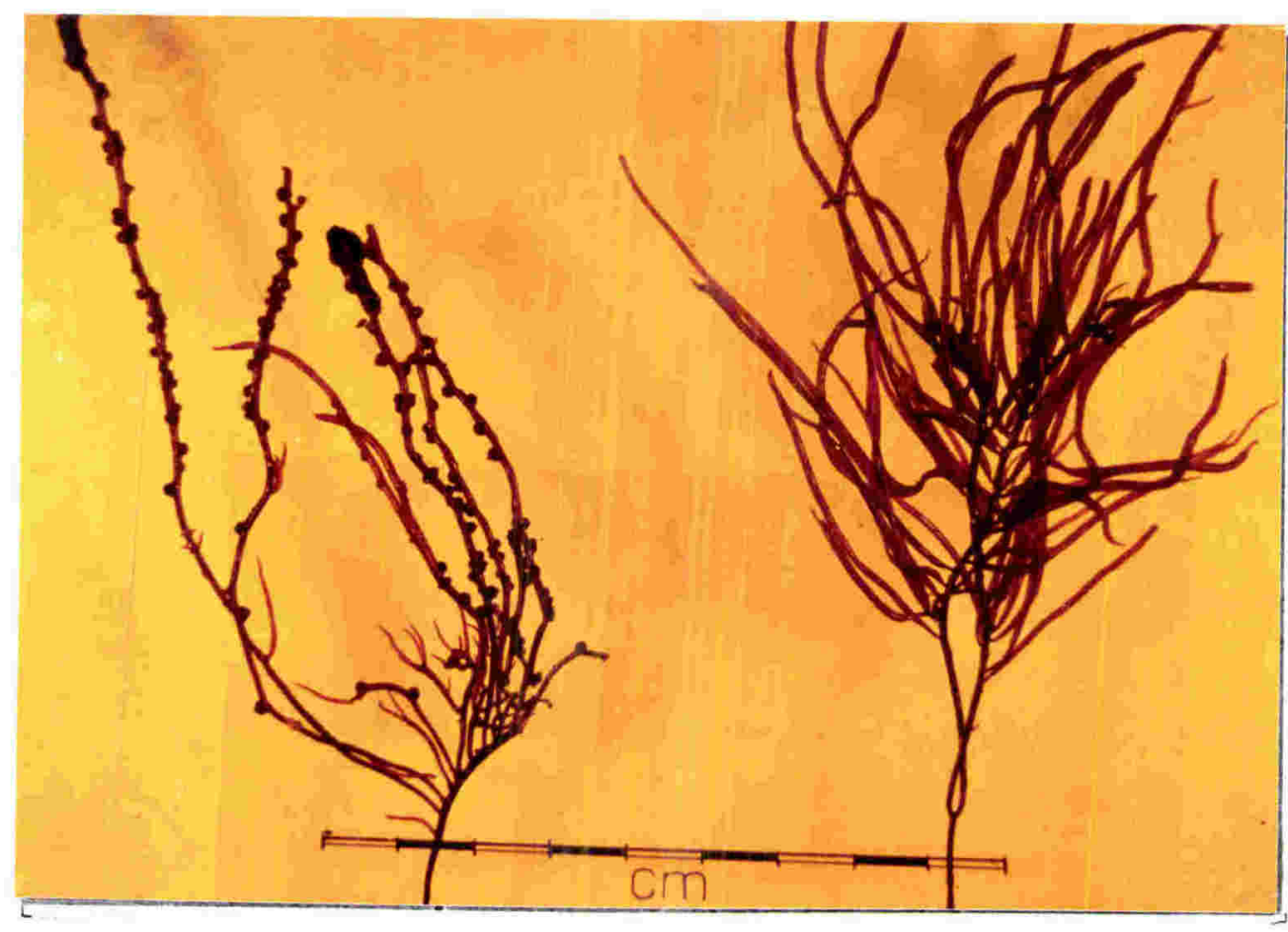

FEMALE

TETRASPOROPHYTE

8.18. Habit of Gracilaria secundata from Island Bay, Wellington 
Appendix 9. The effects of washing time on agar yield and gel strength of Gracilaria sordida.

\subsection{INTRODUCTION.}

Worldwide studies on many Gracilaria species have shown that agar yield and gel strength in this genus vary considerably as a function of biological and environmental factors such as species, genetic differences within species, population, thallus age, stage of life cycle, season, nitrogen concentration, temperature and salinity (Asare, 1980; Bird et al., 1987; Cote and Hanisak, 1986; Craigie et al., 1984; Craigie and Wen, 1984; Daugherty and Bird, 1988; DeBoer, 1979; Durairatnam, 1987; Hoyle, 1978; Lignell, 1988; Miller and Furneaux, 1987; Oza, 1978; Patwary and van der Meer, 1983; Tam and Edwards, 1982; Wang and Yang, 1980). Mariculture of Gracilaria species for the commercial production of agar is being investigated to control some of these environmental factors in order to maximize the gel quantity and quality (Cote and Hanisak, 1986; Craigie et al., 1984; Rotem et al., 1986).

Among the important factors that have been shown to cause variation in agar quality and quantity are the method of extraction and pretreatment procedures (Santos, 1980; Durairatnam, 1987). Reported times for washing the dry seaweed prior to the extraction varied from 15 minutes (Santos, 1970) to 3 hours (Pickering, 1990). In 1988 Lahaye and Yaphe reported that extensive washing of the dry seaweed with water prior to the hot water extraction will result in a low agar yield. The purpose of this study was to determine the optimum washing time for dried Gracilaria sordida prior to extraction, in order to maximize yield and quality.

\subsection{MATERIALS AND METHODS.}

Gracilaria sordida (tetrasporophyte) samples were collected in summer (December January) 1989 from Pauatahanui Inlet, Porirua Harbour, Wellington. Plants were washed in seawater and then rinsed in tap water. All foreign material and epiphytes were removed, and 
the plants were then weighed and dried to constant weight for 48 hours at $60^{\circ} \mathrm{C}$ in an oven. Before extraction, samples $(10 \mathrm{~g})$ of the dried seaweed were washed in running distilled water for a range of times from $0.5 \mathrm{~h}$ to $3 \mathrm{~h}$ (two replicates per time) then redried. Agar was then extracted from these samples following the method of Pickering (1990) as described in Chapter 4 .

\subsection{RESULTS.}

The yield of agar (\% dw) and gel strength $\left(\mathrm{g} . \mathrm{cm}^{-2}\right)$ of Gracilaria sordida extracted after different periods of washing the dry weeds samples are shown in Figure 9.1.

The highest yields were obtained from the samples washed for $1.5 \mathrm{~h}(28 \%)$ and the lowest yields from the samples washed for $3 \mathrm{~h}$. The yield did not show a significant decrease from $2 \mathrm{~h}$ to $3 \mathrm{~h}$ of washing time.

The gel strength ranged from 74 to $171.5 \mathrm{~g} . \mathrm{cm}^{-2}$. The highest gel strength was obtained from the samples washed for $1 \mathrm{~h}$ and the lowest from the samples washed for $3 \mathrm{~h}$. 
washing times prior to extraction on agar yield and gel strength of Gracilarla sordida

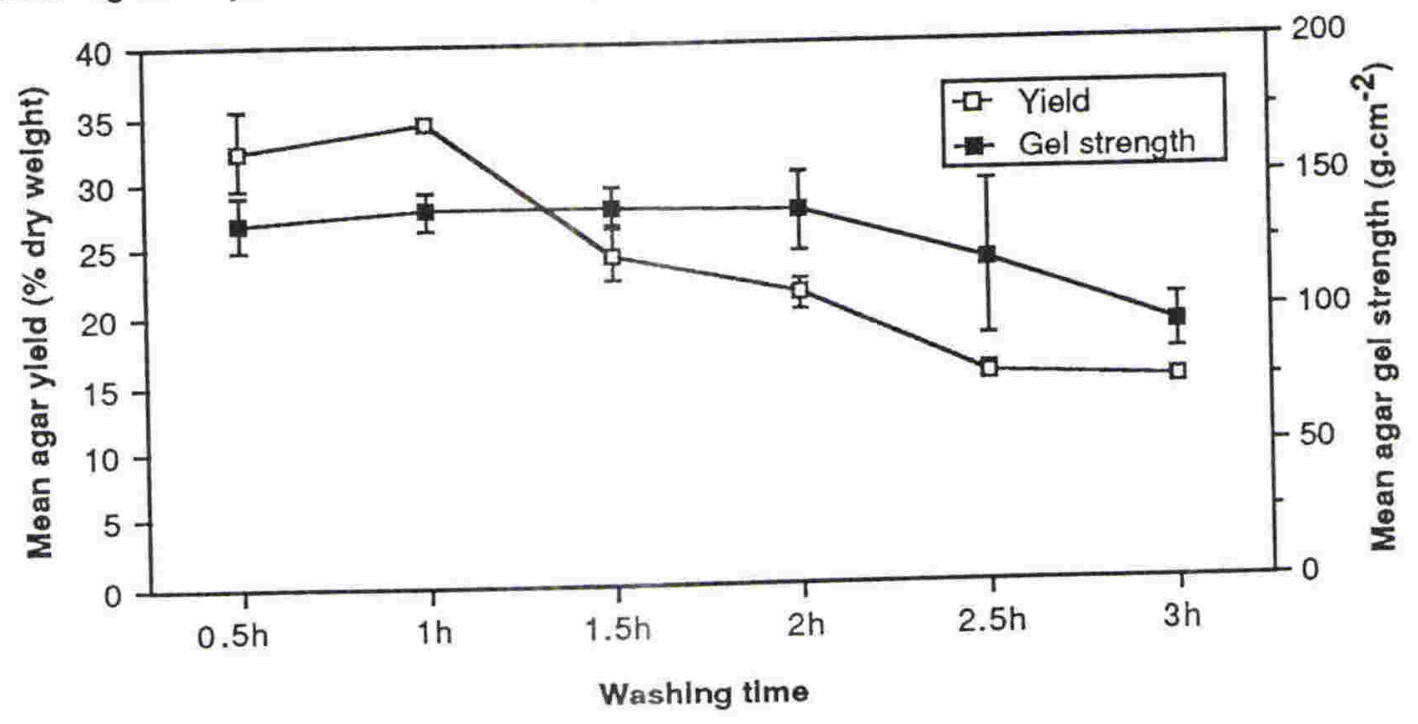

Figure 9.1. Agar yield and gel strength of Gracilaria sordida tetrasporophytes as a function of washing time of the dry seaweed prior to extraction. Vertical bars are $95 \%$ confidence intervals. 


\subsection{DISCUSSION.}

The effects of washing time of the dry seaweed prior to extraction on agar yield and gel strength were significant. Yield decreased after $2 \mathrm{~h}$, the difference between $2 \mathrm{~h}$ and $3 \mathrm{~h}$ being significant. Gel strength decreased throughout the washing time showing significant reductions after $1 \mathrm{~h}$ and after $2 \mathrm{~h}$. If prolonged washing may have removed the cold-water-soluble agar fraction (non-gelling galactan) or other unknown factors and resulted in a decrease in the agar quantity and quality as reported by Wood (1946), Durairatnam (1987) and Lahaye and Yaphe (1988).

\subsection{CONCLUSION.}

Yield and gel strength of agar extracted from Gracilaria sordida after a range of washing times showed an overall decrease with increasing washing time. The optimum washing time was $1 \mathrm{~h}$. 


\section{BIODATA}

Sompop Intasuwan was born on the $10^{\text {th }}$ August 1950 in Trat Province, Thailand. He finished his masters degree from Srinakharinwirot University (Prasarnmitr) in 1975. Soon after graduation, he joined the staff of Srinakharinwirot University, Songkhla campus as a lecturer in the Biology Department. He was promoted to assistant professor in 1983. In 1984 he was awarded a scholarship for training in seaweed research under Dr Margaret Clayton at Monash University, Melboume, Australia. After returning from Australia in 1985, he joined the Agriculture Technology Transfer Project (ATT) and started working on Gracilaria farming in Songkhla Lagoon. In 1987 he received a grant from the New Zealand Government (Overseas Development Aid) and started working on his doctoral degree under Dr Margaret Gordon at Victoria University of Wellington. His doctoral dissertation records his research on the agarophyte Gracilaria sordida in New Zealand, the main topics being the sporulation, farming feasibility, agar quantity and quality, and genetic variation of this seaweed which is widely distributed around New Zealand. 